\title{
Propedêutica da grossura
}

\section{Juliana Villela Junqueira}

Tese apresentada à

Faculdade de Arquitetura e Urbanismo

da Universidade de São Paulo para

obtenção do Título de Doutor

Área de concentração:

Projeto, Espaço e Cultura

Orientador: Prof. Dr. Luís Antônio Jorge

São Paulo 2020 
AUTORIZO A REPRODUÇÃO E DIVULGAÇÃO TOTAL OU PARCIAL DESTE TRABALHO, POR QUALQUER MEIO
CONVENCIONAL OU ELETRÔNICO, PARA FINS DE ESTUDO E PESOUISA, DESDE OUE CITADA A FONTE.

EMAIL DA AUTORA: julianajunqueira@usp.br

\section{Catalogação na Publicação}

Serviço Técnico de Biblioteca

Faculdade de Arquitetura e Urbanismo da Universidade de São Paulo

Junqueira, Juliana Villela

Propedêutica da grossura / Juliana Villela Junqueira;

orientador Luís Antônio Jorge. - São Paulo, 2020.

244 p.il.

Tese (Doutorado) - Faculdade de Arquitetura e Urbanismo da Universidade de São Paulo. Área de concentração: Projeto, Espaço e Cultura.

1. Lina Bo Bardi. 2. Arte e Indústria. 3. Práticas

Pedagógicas. 4. Cultura Brasileira. I. Jorge, Luís Antônio, orient. II. Título.

Elaborada eletronicamente através do formulário disponível em: <http://www.fau.usp.br/fichacatalografica/> 


\title{
Ficha de Aprovação
}

\author{
Autor: \\ Juliana Villela Junqueira \\ Título: \\ Propedêutica da Grossura
}

Tese de Doutorado apresentada à Faculdade de Arquitetura e Urbanismo da Universidade de São Paulo. Área de concentração: Projeto, Espaço e Cultura.

Data de Aprovação:

\section{Banca Examinadora:}

Prof. Dr.

Instituição:

Prof. Dr.

Instituição:

Prof. Dr.

Instituição:

Prof. Dr.

Instituição: 

para meu pai Lucio Costa Junqueira 



\section{Agradecimentos}

Este trabalho é resultado do diálogo transcorrido nos últimos dez anos com meu orientador, Luis Antônio Jorge. Uma conversa que atravessa a cultura brasileira na formalização da arquitetura, desde a construção da dissertação Modernos Trópicos - Brasil e Brasília. As questões apontadas em Propedêutica da Grossura decorrem desse convívio, frente à sua produção acadêmica e trajetória dentro da universidade pública, em diálogo permanente com seus alunos. Também foi em ato, que pude acompanhar a construção do seu método, que reside no fazer, o que possibilitou minha mirada para as questões pedagógicas parte do processo em si. Por isso, a ele agradeço em primeiro lugar.

Os desdobramentos dessa conversa se estendem aos integrantes do grupo do pesquisa "Representação dos lugares na cultura brasileira": Professora Ana Maria Belluzzo, pela direção precisa na banca de qualificação, encaminhado a tese para as questões aqui colocadas, somada à importância dos documentos reunidos em sua pesquisa no International Center for the Arts of the Americas do Museum of Fine Arts, em Houston; Professor Marcelo Suzuki, pela presença desde meu trabalho anterior e cujo livro Tempos de Grossura: o design no impasse foi o ponto de partida [e de chegada] dessa tese e a Professora Marina Grinover, pelo trabalho-referência na sistematização das ideias de Lina.
Agradeço as imagens cedidas do seu acervo pessoal da Revista A, fotografadas por Carlos Kipnis.

Aos professores que de outras formas acompanharam a elaboração deste trabalho: Guilherme Wisnik, Fernanda Fernandes e Sophia Telles.

Ao Fernando Bizarri, pela qualidade da diagramação da tese.

Agradeço a disponibilidade da equipe técnica da Biblioteca da FAUUSP e a Secretaria de pós-graduação, especialmente à Diná.

A Capes, cujo financiamento para o desenvolvimento de pesquisas em Arquitetura é fundamental.

À amiga Eloá Mattos, minhainterlocutora em Salvador. À Sandra Regina Jesus do Núcleo de Acervo e Pesquisa Museológica e à Tereza Lino, diretora do Museu de Arte Moderna da Bahia, pela pronta disposição do acesso aos arquivos, aqui reproduzidos.

Ao Centro de Pesquisa do MASP e ao Instituto Lina Bo e P.M. Bardi, especialmente à Carolina Tatani.

Aos companheiros nascidos da luta pela construção coletiva da gestão pública e democrática, no CEI 13 de maio e ao núcleo resistente de professores da Prefeitura Municipal de São Paulo, herdeiros de Paulo Freire.

À família, pelo apoio incondicional: Mariza, Lulu, Rô, Vicente, Gabriel e Teo. Ao Digo, companheiro integral em todos os momentos, meu grande interlocutor. 



\section{Gli uomini pensano da soli a se stessi, niente possono comprare e niente c’è da comprare.}

[Anotações sobre o Nordeste, para o livro

Tempos de Grossura. Arquivo ILBPMB.] 



\section{Propedêutica da grossura}

\section{Resumo}

Entendendo a teoria no bojo da experiência de simplificação, desdobrada em sua experiência na Bahia, essa tese busca retomar a produção de Lina Bo Bardi, nas práticas institucionalizadas por ela, nos três primeiros museus que concebeu - MASP, MAMB e MAPU - procurando identificar os conceitos-chave que balizaram suas ações pedagógicas, que culminariam no projeto da Escola de Desenho Industrial e Artesanato, na Bahia, em 1963. Tal projeto, que buscou uma aproximação com a recém-criada SUDENE, sintetizaria seus esforços acerca do enfrentamento dos paradoxos do processo de industrialização brasileira no desenvolvimento de um método capaz de produzir, reproduzir e, logo, transmitir, uma cultura material industrial vinda da simplificação. O título - Propedêutica da Grossura - condensa a hipótese do trabalho de que, a partir de um corpo preliminar teórico construído em ato por meio das práticas pedagógicas, Lina buscaria sistematizar um método derivado do conjunto de conhecimentos preliminares da Grossura, marcados pela inventividade de uma cultura material possível, formalizando, dessa forma, a propedêutica da grossura como práxis.

Palavras-chave: Lina Bo Bardi, arte e indústria, cultura brasileira, práticas pedagógicas.

\section{The theory of rudeness}

\begin{abstract}
Through a approach unfolded in Lina BoBardi's experience in Bahia, this thesis focuses on her work and the methodology she left behind by taking a deep approach on the first three museum projects she built - MASP, MAMB and MAPU - as a pursuit of the key and core concepts guiding her actions in education, which culminated in the development of the school of industrial design 'Escola de Desenho Industrial e Artesanato' in 1963. This project, which sought an approximation with the newly created 'SUDENE' directed its focus towards facing the paradoxes and adversities of the brazilian industrialization process in the development of a methodology capable of comprehending, reproducing and transmitting a material industrial culture based on simplification. The title The theory of rudeness captures and synthesizes the idea of a preconceived theoretical structure materialized through educational practices as Lina's way of codifying a system derived from a set of ideas preliminaries of rudeness marked by the inventiveness of a tangible material culture capable of formalizing 'the theory of rudeness' as praxis.
\end{abstract}

Key words: Lina Bo Bardi, art and industry, brazilian culture, pedagogical practices. 



\section{Propedêutica da grossura}

\section{Introdução: PROBLEMAS DE MÉTODO}

23 Teoria em ato: Contribuição Propedêutica

31 Atualização Metodológica

37 As heranças são pesadas, e as 'não-heranças' [...] perigosas.

\section{PRÁTICAS PEDAGÓGICAS}

I.

MASP

49 Os puristas são enfadonhos e inúteis

53 Agenda Didática

67 A nossa revista, que nada tem de etnográfica

$79[\ldots]$ O povo se aborrece [...] com tudo aquilo que é inútil

83 Paradoxos da industrialização

89 Com a farinha de nosso saco

II.

MAMB

107

Exílio do Estado

111 Um olho sobre a Bahia

141 Políticas públicas e subdesenvolvimento

145 Soyons artistes, nous le pouvons

161 Escola e "Movimento"

III.

\section{MAPU}

187 Arte com A maiúsculo

191 Práticas culturais e populares ligadas ao mundo artesanal

199 Projeto Político Pedagógico

209 Weimar 1918 está longe na História

221 Uma acusação

\section{CONSIDERAÇÕES FINAIS}

235 Etnografia versus Projeto 



\section{Lista de Imagens}

IMG 1. Vista aérea da Acrópole de Atenas [BARDI,1957:12]

IMG 2. Vista do Conjunto do Solar do Unhão. [FERRAZ, 1992:153]

IMG 3. Ricostruzione e Democrazia. [Revista A, 1946].

IMG 4. Transatlântico "Empress of Australia" [MOHOLY-NAGY, 1929:31]

IMG 5. Salvador, feira de Água dos Meninos. [BARDI, 1957].

IMG 6. Maçaneta de níquel (1922) e Calefator (1931). Walter Gropius. [BARDI,1957:89]

IMG 7. A Scuola. [Revista A, 1946].

IMG 8. Bule feito de lata de manteiga. [Arquivo ILBPMB].

IMG 9. Objetos Exposição Bahia, 1959. [Domus n.284, 1953:26].

IMG 10. Projetor de madeira, arame e flandre, 1960. [Malasartes, n.2, jan/fev/mar 1976]

IMG 11. Bule de flandre de lata de Toddy, Caruru, PE, 1960. [Malasartes, n.2, jan/fev/mar 1976]

IMGS 12 -17. Objetos. Nordeste, 1960. [Arte Vogue, n.2, 1980]

IMG 18. Canecas Lata, Expo A mão do Povo, 1969. [Arquivo MASP].

IMGS 19-20. Fruteira Albers, 1923 e Jogo de panelas, Sambonet, 1965. [Malasartes, n.2, jan/fev/mar 1976]

IMG 21. Cadeira Tribo Africana [Arquivo ILBPMB].

IMG 22. Cadeira Beira-de-estrada, 1967. [Arquivo ILBPMB].

IMG 23. Brasília: cinco dias. [LISPECTOR, 1978:12]

IMG 24. Modigliani em New York. [Habitat n.1, p.92]

IMG 25. Brazil Builds. [GOODWIN, 1943: s/n.]

IMG 26. "O que é um museu?" [Habitat n.9,p. 52.]

IMG 27. Revista $A$-eletrodomésticos. [Revista $A$, 1946].

IMG 28. Exposições Didáticas. [Habitat n.1, p.35]

IMG 29. Exposições Didáticas. [Habitat n.1, p.35]

IMG 30. Vitrine das Formas. [Habitat n.1, p.35]

IMG 31. Vitrine das Formas. [Habitat n.1, p.35]

IMG 32. "Habitat", [Habitat n.12, p.96]

IMG 33. "Mais uma amadora". [Habitat n.7, p.40]

IMG 34. "O índio desenhista". [Habitat, n.1, p.66]

IMG 35. Clube Infantil de Arte. [Habitat, n.1, p.93]

IMG 36. Imprensa. [Diário de S.Paulo]

IMG 37. "Gravatas" [Habitat n.2, p.95]

IMG 38. "Fantasias Musicais" [Habitat n.2, p.95]

IMG 39. "Zonti" [Habitat n.4, p. 96]

IMG 40. "legenda" [Habitat n.7, p.95]

IMG 41. "Método". [Habitat n.2, p.89]

IMG 42. "Uma notícia triste" [Habitat n.8, p. 95]

IMG 43. "Odisseia" [Habitat n.6, p.94] 


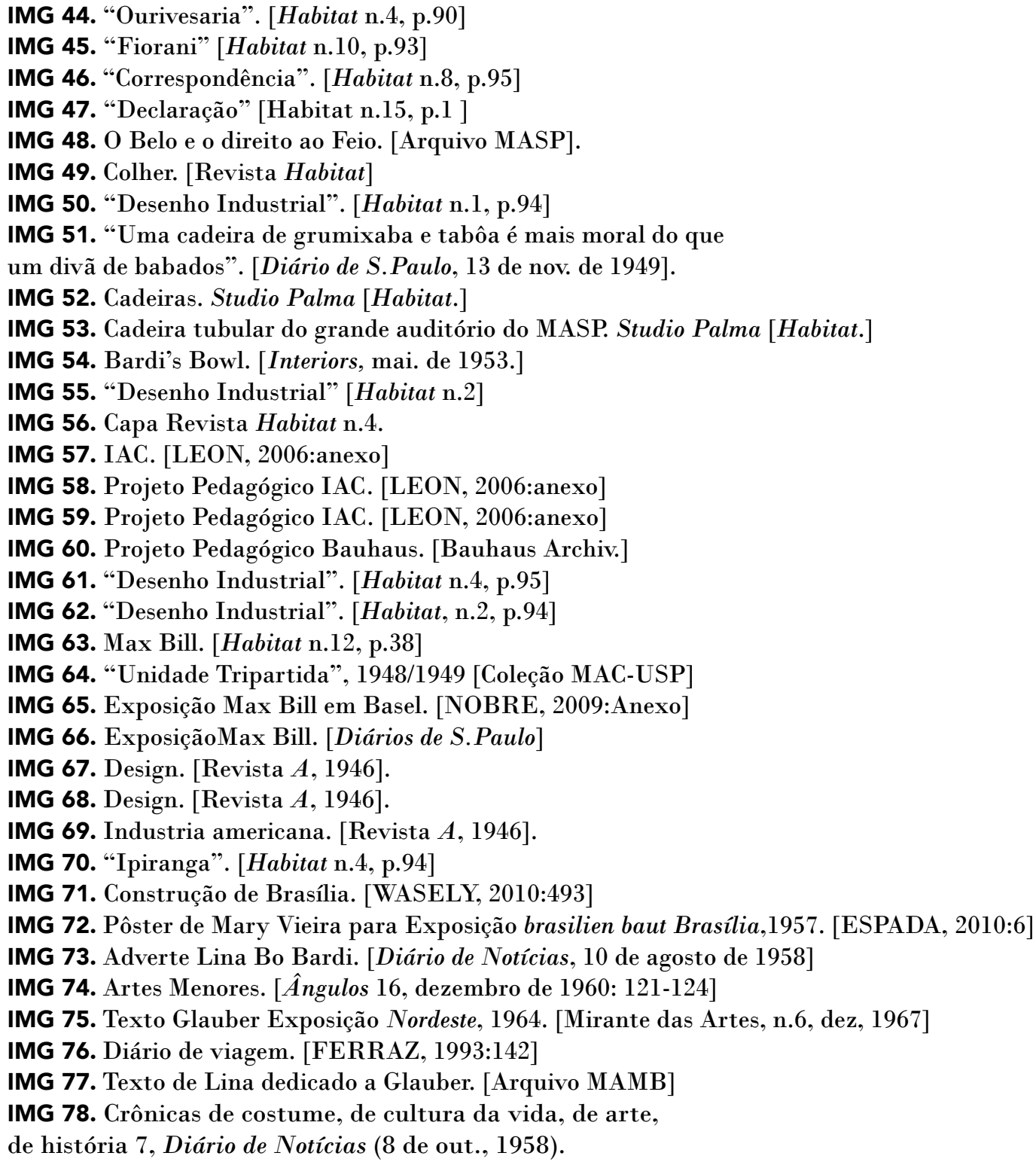


IMG 79. "A Intolerância", Crônicas de costume, de cultura da vida, de arte, de história 7, Diário de Notícias (19 de out. de 1958).

IMG 80. "Resposta", Crônicas de arte, de história, de costumes, de cultura da vida 8, Diário de Notícias (26 de out. de 1958).

IMG 81. "Antologia". Crônicas de arte, de história, de costumes, de cultura da vida 1, Diário de Notícias (7 de set. de 1958).

IMG 82. "Olho sobre a Bahia". Crônicas de arte, de história, de costumes, de cultura da vida 2, Diário de Notícias (14 de set. de 1958).

IMG 83. "Qual dos dois você escolheria?" Crônicas de arte, de história, de costumes, de cultura da vida 8, Diário de Notícias (26 de out. de 1958).

IMG 84. Quale scegliereste? . [Revista $A$ n.4, abr., 1946].

IMG 85. Tarde mecanizada. Crônicas de arte, de história, de costumes, de cultura da vida 1, Diário de Notícias (7 de set. de 1958). Arquivo ILBPMB.

IMG 86. Noturno. Crônicas de arte, de história, de costumes, de cultura da vida 3, Diário de Notícias (21 de set. de 1958). Arquivo ILBPMB.

IMG 87. Retrato de família. Crônicas de arte, de história, de costumes, de cultura da vida 5, Diário de Notícias (5 de out. de 1958). Arquivo ILBPMB.

IMG 88. Paisagem. Crônicas de arte, de história, de costumes, de cultura da vida 6 , Diário de Notícias (12 de out. de 1958). Arquivo ILBPMB.

IMG 89. Interior. Crônicas de arte, de história, de costumes, de cultura da vida 7 , Diário de Notícias (19 de out. de 1958). Arquivo ILBPMB.

IMG 90. Desenho para Crônicas, etc. Arquivo ILBPMB.

IMG 91. "Inatualidade da Cultura". Crônicas de arte, de história, de costumes, de cultura da vida 3, Diário de Notícias (21 de set. de 1958).

IMG 92. "A Escola e a Vida". Crônicas de arte, de história, de costumes, de cultura da vida 3, Diário de Notícias (21 de set. de 1958).

IMG 93. III Semana Nacional de Estudantes de Filosofia, 1960. Arquivo MAMB

IMG 94. "Arte industrial". Crônicas de arte, de história, de costumes, de cultura da vida 8, Diário de Notícias (26 de out. de 1958).

IMG 95. O Estado de São Paulo, 22 de set.,1959.

IMG 96. Rascunho Artes Menores, 1960. Arquivo MAMB.

IMG 97. Diario da Noite, 22 de set., 1959.

IMG 98. O Estado de São Paulo, 22 de set.,1959.

IMG 99. Cartaz. [FERRAZ, 1993:135]

IMG 100. Diario de São Paulo, 13 de set., 1959.

IMG 101. Recorte de jornal Bahia no Ibirapuera.

IMG 102. Diario de São Paulo, 18 de set., 1959. 
IMG 108. Catálogo Exposição Bahia, 1959.

IMG 109. Catálogo Exposição Bahia, 1959.

IMG 110. Revista Mirante das Artes, Etc. 6, nov. de 1967.

IMG 111. Jornal da Bahia. Salvador, 21 de set., 1960.

IMG 112. Técnica e Arte. Diario de S. Paulo. 4 de dez., 1960.

IMG 113. Rose et Bleu. Diário de Noticias.

IMG 114. Formais Naturais. [FERRAZ, 1993:138]

IMG 115. Museu de Arte Moderna da Bahia. Salvador, [1959?]. Arquivo MAMB.

IMG 116. Manuscrito. s/d. Arquivo MAMB.

IMG 117. Texto de assinatura de convênio, s/d, [1960?]. Arquivo MAMB.

IMG 118. Felix Labisse. 17 de out. de 1959. Arquivo MAMB.

IMG 119. "Calígula e a crítica teatral". Arquivo MAMB.

IMG 120. Textos-parede das Exposições Didáticas. Arquivo MAMB.

IMG 121. Lista de Exposições. Arquivo MAMB

IMG 122. Resumo das Atividades. Arquivo MAMB

IMG 123. Camus. Arquivo MAMB

IMG 124. Ex- voto. [SUZUKI, 1994:22].

IMG 125. "In cerca di mobili", A Cultura della Vita,

n. 9, 1946. Foto Carlos Kipnis. Acervo Grinover.

IMG. 126. O bívio. [Malasartes, 1976]

IMG 127. Revista [Habitat, n.1:77]

IMG 128. Lamparina (fifó). Foto Arquivo ILBPMB.

IMG 129. Celso Furtado em viagem da Sudene. [RISÉRIO, 1995: álbum]

IMG 130. Notas de Arte. [Diarios de Notícias, 20 de mar., 1961]

IMG 131. Carta para Milton Santos, 06/06/1963. Arquivo MAMB.

IMG 132. Carta ao governador, $01 / 05 / 1953$. Arquivo MAMB.

IMG 133. Canecas feitas com latas de lubrificantes. [SUZU KI, 1994:63]

IMG 134. Lamparina feita com lata de leite. Arquivo ILBPMB.

IMG 135. Unhão [FERRAZ, 1993:154]

IMG 136. Escada do Unhão. Arquivo ILBPMB

IMG 137. Escada do Unhão. Arquivo ILBPMB.

IMG 138. Levantamento CETA. Arquivo ILBPMB.

IMG. 139. Triângulo do Nordeste. [FERRAZ, 1993:152]

IMG. 140. Texto sobre artesanato. Arquivo MAMB.

IMG 141. Pano de algodão. [SUZUKI, 1994:30]

IMG 142. Exercícios Bauhaus - Klee [Arquivo Zemtrum Paul Klee].

IMGS 143-144. Esquema Escola de Desenho Industrial e Artesanato. Arquivo MAMB 
IMGS 145. Revista $A, 1946$. Foto Kipnis. Acervo Grinover.

IMGS 146-47. "Biênio propedêutico". Arquivo MAMB.

IMG 148. Texto Universidade Popular. Arquivo MAMB.

IMG 149. Anotações Lina. Arquivo MAMB.

IMG 150. Cabeça de cavalo. Ex-voto. [SUZUKI, 1994:18]

IMG 151. Lamparina dobrável parede-mesa. [SUZUKI, 1994:25]

IMG 152. Escultura musical produzida por Smetak. [RISERIO, 1995:álbum]

IMG 153. Brinquedo. [SUZUKI, 1994: 14]

IMG 154. Arte popular. [SUZUKI, 1994: capa]

IMG 155. Privada. Barro Natural. [SUZUKI, 1994:25]

IMG 156. Uma antecipação baiana da pop art. [Diario de S.Paulo, 1963]

IMG 157. Rascunho Exposição Nordeste, 1963. Arquivo MAMB.

IMG 158. Carybe. Arquivo MAMB

IMG 159. Telegrama. [RISERIO, 1995:álbum]

IMG 160. Lina. Arquivo ILBPMB.

IMG 161. Lina e Verger . [RISERIO, 1995:223] 



\section{Introdução: PROBLEMAS DE MÉTODO}

Em setembro de 1957, Lina Bo Bardi apresenta a tese Contribuição propedêutica ao Ensino da Arquitetura, ${ }^{1_{1}}$ como requisito do Concurso público para primeira cátedra da disciplina Teoria da Arquitetura na Faculdade de Arquitetura e Urbanismo da Universidade de São Paulo.

Em torno do papel da teoria da arquitetura, a tese se apresentava dividida em "Problemas da arquitetura" e "Problemas de método" e tais problemáticas continham a ideia de atualização do escopo pedagógico da disciplina, a partir da transposição dos significados das teorias de arquitetura no entendimento dos sistemas que lhes deram origem ao contexto brasileiro, diferente em sua história e, consequentemente, em suas práticas.

Seria interessante estabelecer quais as teorias que, historicamente, prevaleceram no desenvolvimento da arquitetura brasileira, através de seus quatro séculos de existência, indagando quantas e quais as contribuições do elemento local se afirmou e permaneceu no espírito de uma teoria em ato. E este o sentido autêntico do termo 'nacional', o qual, destituído de vazias significações político-nacionalistas, levará a uma colaboração internacional, com a contribuição efetiva e vital das atividades particulares, que satisfaçam as necessidades espirituais e materiais de cada

1 BARDI, Lina Bo. Contribuição propedêutica ao Ensino da Arquitetura. São Paulo: Habitat, 1957. 
país. Esta soma de contribuições, sintetizado numa linguagem internacional será a base de uma nova cultura que, como acreditamos, não será mais 'europeia' ou 'americana', e sim a cultura mundial. Esta linguagem não será a do 'cosmopolitismo' abstrato e vago, nem tão pouco das reivindicações 'nacionais' de caráter estético-ideológico. ${ }^{2}$

Lina formalizaria, assim, uma atitude propositiva em relação ao ensino que revelava o compromisso em fomentar um campo institucional com adesão aos problemas colocados no horizonte imediato. As teorias deveriam, assim, ser cotejadas nas complexas relações entre ensino e prática, expandindo as amarras da filosofia em direção à práxis.

Alguns talvez achassem oportuno que se definisse previamente o sentido mesmo do conceito de 'teoria'. Ora, é verdade que, até certo ponto, poderíamos, com isso, correr o risco de estabelecer um círculo vicioso, visto que definido 'teoréticamente' 'teoria', é ainda permanecer no interior de seu âmbito; e é certo, por outro lado, que toda investigação particular e determinada - como é a nossa - não pode, a rigor, deixar de partir de certos pressupostos metodológicos que delimitem o seu tempo, e por isso mesmo, não pode tomar esses mesmos pressupostos como objeto de sua pesquisa, sob pena de sair de si própria, e fazendo sua própria crítica, deixar de ser, digamos 'ciência' para ser 'filosofia', ou seja o estudo acerca das condições de possibilidade da ciência mesma enquanto investigação particular e determinada. ${ }^{3}$

Em consequência, não haveria uma teoria válida ad infinitum, bem como uma autonomia possível entre teoria e prática - ambas, logo - dialeticamente sincrônicas, mudando a rota imposta pela guerra, em que "o campo da 'Prática' se abandonava pela "Teoria" ${ }^{"}{ }^{4}$ Longe de subordinar o teórico ao prático, no sentido habitual, ou mais comum, desta última palavra; a rigor, a práxis é entendida aqui como a união da teoria com a prática, fundamento de toda possível teorização, ${ }^{5}$ de tal forma que "a elaboração teórica pode provir da prática e ser sua consequência". Assim, continuaria no ano seguinte, na ocasião da primeira aula no curso de arquitetura da Faculdade de Belas-Artes da Universidade Federal da Bahia:

O que é teoria? Deixemos de lado (é preciso limitar os problemas) a definição idealista de teoria, que estabelece um círculo vicioso procurando definir 'teoreticamente' a palavra 'teoria' que seria uma forma teórica distinta da prática. Para nós, a teoria se identifica com a prática demonstrada racional e necessária através da teoria e, por sua vez, a teoria realística e racional [demonstrada] através de sua prática. ${ }^{7}$

Citando Manuel de Araujo Porto-Alegre no prefácio da tese, Lina sintetiza o entendimento da arquitetura como "o produto ou, melhor ainda, a projeção do homem civilizado no mundo", ${ }^{8}$ que será o argumento central sobre o qual se desdobram os problemas de teoria e os de método, apontando o exercício de formular as perguntas através do tempo, inscritas nas obras realizadas.

Não há uma pedra posta pela mão do homem no centro das suas cidades, que não exprima uma ideia, que não represente uma letra no alfabeto da civilização.

2 Ibidem, p.70

3 BARDI, Lina Bo. Contribuição propedêutica ao Ensino da Arquitetura. São Paulo: op.cit., p.73.

4 Id. "Curriculum literário". In: FERRAZ, Marcelo (org.). Lina Bo Bardi, 5a ed. Milão/ São Paulo: Instituto Lina Bo e P.M. Bardo/Romano Guerra, 2018, p.9.

5 Cf. Gramsci e o conceito de "filosofia da práxis". In: GRAMSCI, Antonio. Quaderni del Carcere: Edizione crittica dell'Istituto Gramsci a cura di Valentino Gerratana. Torino: Einaudi, 2007. 4 vo

6 BARDI, Lina Bo. Contribuição propedêutica ao Ensino da Arquitetura. São Paulo: op.cit., p.29.

7 Id. "Teoria e filosofia da arquitetura". In: RUBINO, S.; GRINOVER,M. (orgs.). Lina por escrito. Textos escolhidos de Lina Bo Bardi. São Paulo: Cosac Naify, 2009, p.82.

8 Id. Contribuição propedêutica ao Ensino da Arquitetura. São Paulo: op.cit., p.5.

9 BARDI, Lina Bo. Contribuição propedêutica ao Ensino da Arquitetura. São Paulo: op.cit., p.5 
Logo, como "produto da experiência do homem no tempo [...] não existe fratura entre o assim chamado 'moderno' e a história, visto ser o 'moderno' antes o produto da história mesma, através da qual somente é possível evitar as repetições de experiências superadas". ${ }^{10}$

Teoricamente, a história não serve mais, a não ser como uma velha ponte que permite atravessar um rio; por outras palavras, as exigências do homem tornaram-se, não paulatinamente [...], mas subitamente, diversas. $O$ arquiteto é chamado a realizar novos, outros, valores. [...] O homem, segundo o conhecido conceito de Le Corbusier, come, bebe, dorme, trabalha e vive de uma maneira que é diversa da de ontem, pois que o fenômeno da velocidade, e como que o precipitar do bem estar material, recompõem a vida das cidades, enquanto a dos campos vai se constituindo de acordo com a primeira. ${ }^{11}$

Então, "como definir uma teoria normativa, sobretudo se partirmos da premissa de que qualquer teoria se acha em transição e em vir-a-ser?"12 Ao arquiteto caberia, logo, à participação na formação da própria teoria, lembrando que "o que se denomina 'teoria' $[\ldots]$ deveria fornecer [...] a consciência crítica, e a maturidade histórica - além de técnica". ${ }^{13}$

aqui encerramos essas reflexões teóricas, que deveriam ser consideradas uma tomada de posição, não tanto como 'teoria' da Arquitetura, mas, digamos, como 'base didática', tendo a finalidade de mostrar o perigo de um ensino que se alheie aos problemas da vida, os problemas quotidianos (e não tememos essa expressão, porque o homem solitário, que procura resolver seu quotidiano problema de existência realiza, ele também, obra de filosofia e de crítica); no sentido de que o arquiteto, embora consciente dos métodos de indagação diferentes e especializados, deve se manter constantemente em contacto com a vida, no sentido mais comum. ${ }^{14}$

Suas análises dos textos históricos da teoria de arquitetura, ilustradas em diálogos paralelos de projetos de períodos diversos, da antiguidade ao presente, em tratados clássicos, textos críticos acadêmicos, jornais e faturas diversas da vida cotidiana, trazem o conjunto de categorias que atribuíram valores às teorias, no bojo da história, "porque os interesses da arquitetura e de sua teoria concernem problemas de história e de crítica, e sobretudo de interpretação ao serviço da vida de todo dia". ${ }^{15}$

É conveniente que nossas teorias em elaboração sejam, ao mesmo tempo, iluminadas pela convicção e obscurecidas pelas sombras da dúvida que são próprias de nossa época. Se o cientista pode abrigar uma segurança, ou se, pelo menos, a soma de suas experiências pode leva-lo a encontrar uma certeza, e uma verdade, qual será a verdade da arte? Aparentemente a mais relativa. ${ }^{16}$

Corrobora à teoria como práxis, o fundamento ético e moral da prática arquitetônica, "destituída de entusiasmos utópicos, mas ciente de suas próprias responsabilidades", "1" "na consciência profissional [...] inclusive de um ponto de vista filosófico, as relações entre o arquiteto e a sociedade", ${ }^{18}$ para quem "[...] o arquiteto é um operário qualificado que conhece seu ofício não só prática, como teórica e historicamente, e tem precisa consciência de que sua humanidade não é fim em si mesma, mas se compõe, além da sua própria individualidade, dos outros homens e da natureza." ${ }_{19}$

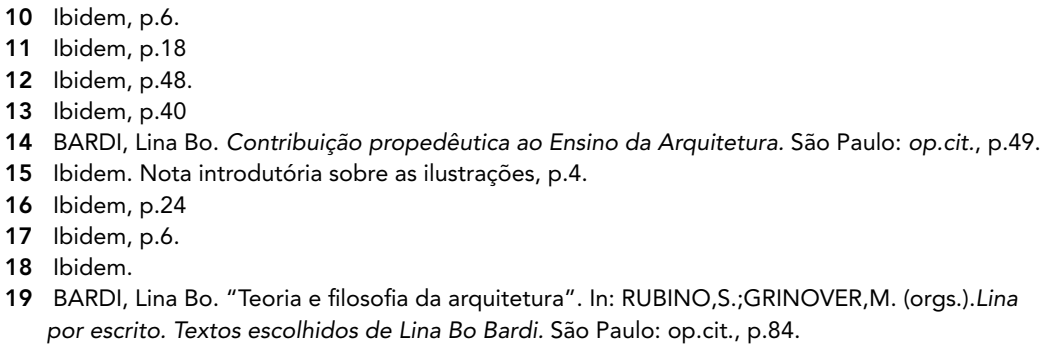


A formação histórica vinda dos tratados clássicos, antes de ser seguida oficialmente, atitude descontextualizada em qualquer lugar do mundo contemporâneo, seu anacronismo se relevaria por princípio e por hábito, "especialmente num país como o Brasil, em que a nova arquitetura vai tomando caracteres particulares." 20 As teorias deveriam então corresponder ao seu tempo, não como um manual de fácil aplicação, antes ideias postas em discussão, como "a leitura da Ilíada deve servir ao conhecimento de um poema eterno e não como exemplo de regras gramaticais gregas." ${ }_{21}$

Bairros residenciais, bem traçados do ponto de vista do urbanismo, embora perdendo de vista as necessidades dos fornecimentos, e ricos de vegetação, aquela exuberante vegetação brasileira que tantas vezes corrige e esconde, beneficamente, feios muros e ridículas fachadas, são muitas vezes, no tocante à Arquitetura stricto sensu, a representação de um cosmopolitismo e de uma linguagem polimorfa, repleta de incongruências curiosíssimas: o estilo mourisco se alterna com aquele, estranhamente denominado 'colonial', que no fundo nada mais é do 'barroquinho' português; o palacete cujo estilo pretende copiar o 'Palazzo Vecchio' de Florença, com torres e complicados brazões de presumidos antepassados, ridículo simulacro italiano, sucede à nórdica provida de telhados inclinadíssimos; e aí encontramos o genérico estilo gótico de pedra e cal, nem sequer vitoriano, e as 'ordens' vignolescas de sexagésima quarta mão; sem falar na penosa remastigação do estilo 'Capitol', que justificou um revival na nova Washington de Jefferson, mas que, em nosso luxuosos 'jardins' não possue sequer o bom gosto de 'sugerir' apenas, a ideia do Novo Mundo. ${ }^{22}$

A arquitetura deveria corresponder ao "costume social constituído pela moral corrente mais generosa, mas até mesmo à moral em contraste e competição com eventuais sistemas e ideias sociais em fase de esgotamento à vista do mudar dos tempos". ${ }^{23}$ E nesse por vir cada vez mais próximo da "significação da utilitas vitruviana", ${ }^{24}$ caberia à arquitetura a proposição de problemas e ideias elementares, consonantes ao tempo "agitado e variado [...], inovador de costumes, ansioso por sínteses e rapidez e quase angustiado pela acumulação de fatos, pensamentos e ações com que o tempo sobrecarregou a fragilidade humana". ${ }^{25}$

Nessa correspondência intrínseca à época, a arquitetura se desprenderia das regras fixas da linguagem para raciocinar através de "emoções" e de "práticas" capazes de infundir novo caráter ao seu desenvolvimento, equacionados pela ciência, pela técnica e pelos costumes - em vertiginosa evolução. ${ }^{26}$

\footnotetext{
20 Id. Contribuição propedêutica ao Ensino da Arquitetura. São Paulo: op.cit., p.8.

21 BARDI, Lina Bo. Contribuição propedêutica ao Ensino da Arquitetura. São Paulo: op.cit.,p.7.

22 Ibidem, p.14.

23 Ibidem, p.48.

24 Ibidem, p.12.

25 Ibidem, p.21.

26 Ibidem,,p.39.
} 


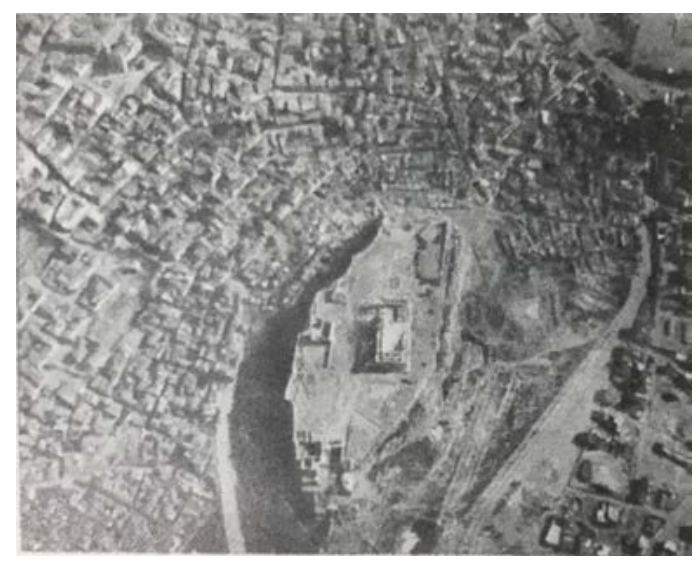

IMG 1.

Vista aérea da Acrópole de Atenas [BARDI,1957:12]

IMG 2.

Vista do Conjunto do Solar do Unhão. [FERRAZ, 1992:153]

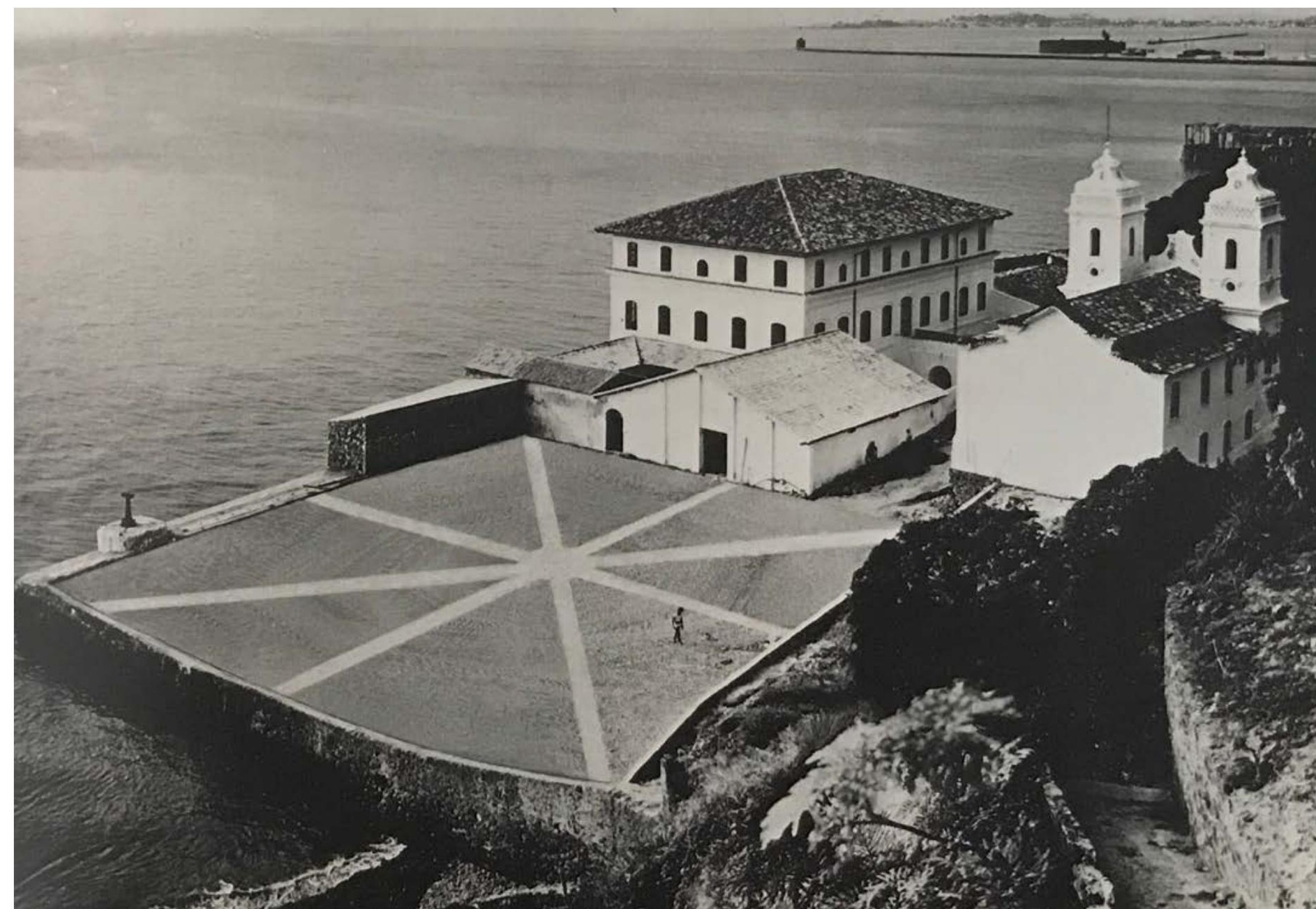




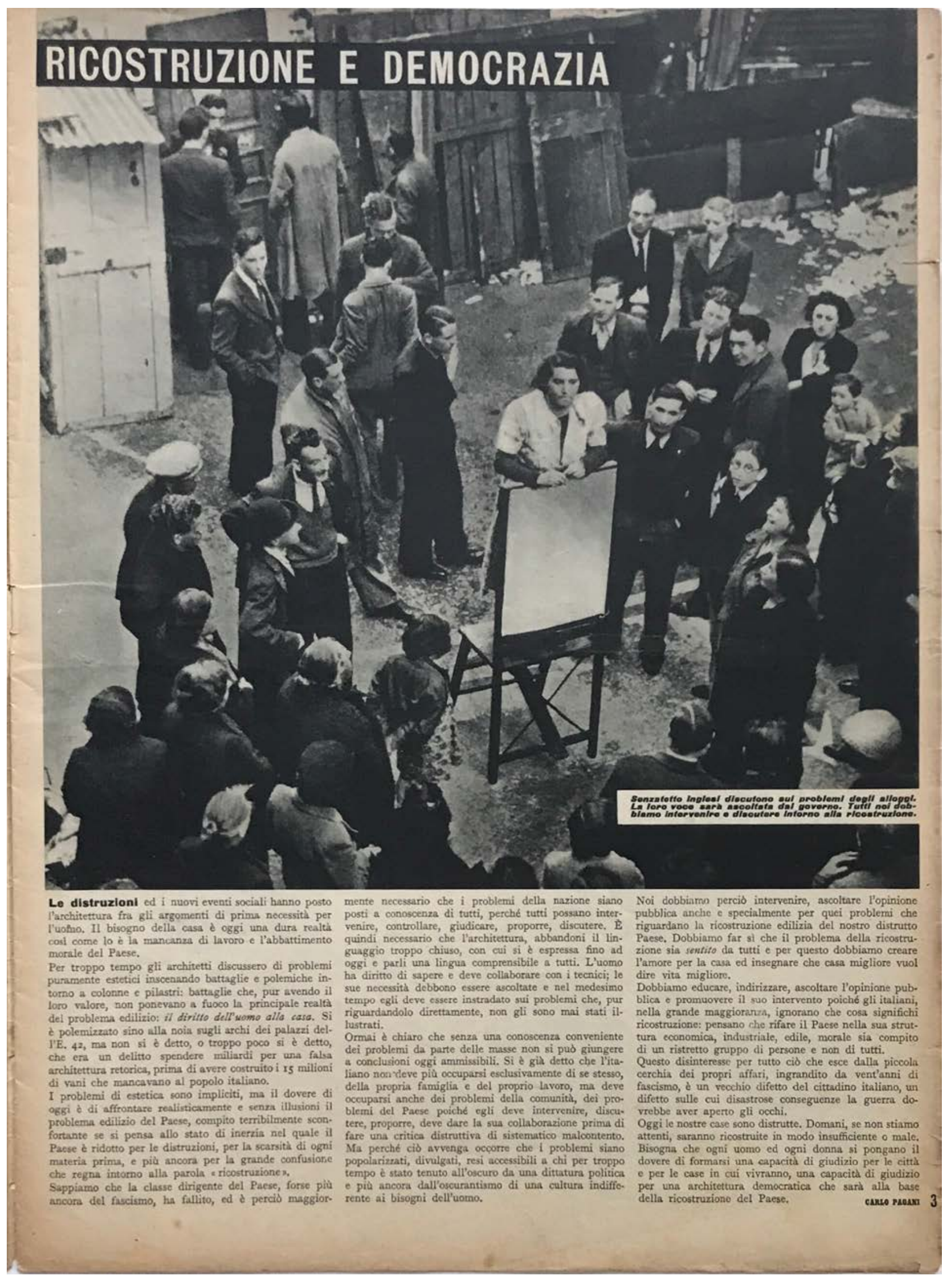

IMG 3.

Ricostruzione e 




\title{
Atualização Metodológica
}

\begin{abstract}
O homem se esforçou, servindo-se dos meios que a própria natureza lhe oferecia, no sentido de modificá-la e reorganizá-la, criando pouco a pouco arquiteturas infinitesimais, que aperfeiçoando-se, foram instaurando no mundo, novas arquiteturas, desde a pedra lascada até o satélite interplanetário, da caverna ao arranha-céu, do amuleto à Catedral. ${ }^{27}$
\end{abstract}

O problema do industrial design e da sociedade de massas está colocado em Contribuição Propedêutica na visada que procura entender o desenvolvimento da arquitetura implicado na passagem da fase artesanal à industrial, "que depende da estética do produto em série e [...] da pré-fabricação de partes que compõem até o todo arquitetônico". ${ }^{28}$ Se a imagem do Transatlântico "Empress of Australia", ${ }^{29}$ retirado do livro de Laszlo Moholy-Nagy Von Material zu Architektur vai ao encontro desse homem moderno "eletrificado, mecanizado, mortificado pelo progresso que ele criou mas ainda não pode compreender", ${ }^{30}$ para Lina os princípios capazes de regular a produção em série - importante frisar - "já [existiam] na própria Natureza, e

27 BARDI, Lina Bo. Contribuição propedêutica ao Ensino da Arquitetura. São Paulo: op.cit., p.11.

28 Ibidem, p.27.

29 Ibidem, p.11.

30 Id. "Teoria e filosofia da arquitetura". In:

RUBINO,S.;GRINOVER,M. (orgs.). Lina por escrito. Textos

escolhidos de Lina Bo Bardi. São Paulo, op.cit., pp.85-86. 
intuitivamente, no trabalho popular". ${ }^{31}$

Diante das novas necessidades do mundo moderno - práticas e 'espirituais' $-{ }^{32}$ caberia ao arquiteto andar pari passu, agindo no cotidiano desse novo homem protagonista do espaço construído - como sugestão de que no estudo da realidade estariam colocados os novos problemas. $\mathrm{E}$, ao circunscrevê-los, "não cair no verbalismo inteligente duma cultura que caminha para, ou já alcançou, o bizantinismo; ${ }^{33}$ raciocínio válido para quem o sentido de cultura "cristalizado e amorfo [...] não tem sentido". ${ }^{34}$

Ciente da dificuldade de sistematização teórica da arquitetura na medida em que sua significação dependeria então da própria produção humana, não surpreende que seu conhecimento mais substancial se dê na chave da teoria, dialogando com a filosofia da práxis como método. Na esteira de que "uma teoria se forma, ou pelo menos recebe uma forte contribuição, a partir dos programas das Escolas", ${ }_{35}$ Lina lembraria das palavras de um jovem arquiteto recém-formado, no Rio de Janeiro, que dizia "[sentir-se] pendurado a um fio, sem saber onde firmar o pé". ${ }^{36}$ Se regras concretas sustentavam as gerações anteriores, codificadas seja pelos tratados de ideias e princípios alheios seja pela facilidade das normas pré-estabelecidas em manuais, o problema da "comunicação didática" ao alcance do conhecimento se tornava premente. ${ }^{37}$

Despimos assim a teoria de todo o aparato que o século XIX tinha colocado em cima dela, e assim, simples e despida, a teoria vem em nossa ajuda para a impostação dos problemas arquitetônicos, como sinônimo e identificação de prática planificada.

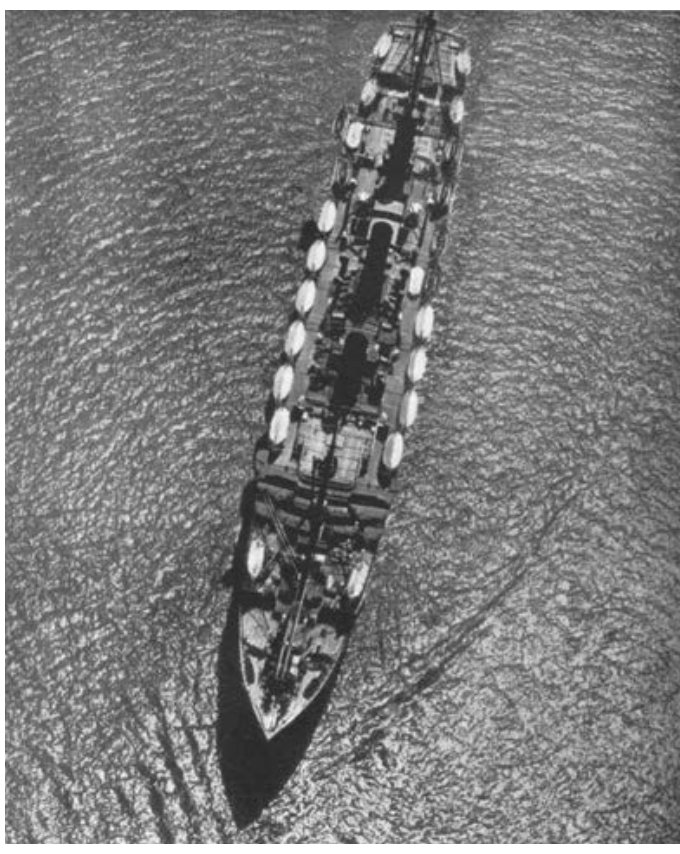

IMG 4.

Transatlântico "Empress of Australia" [MOHOLY-NAGY, 1929:31]

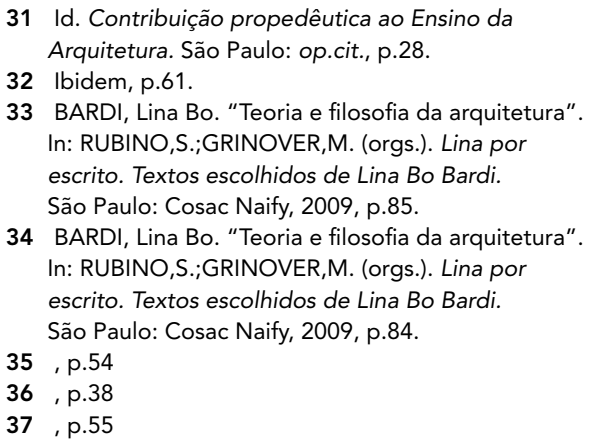




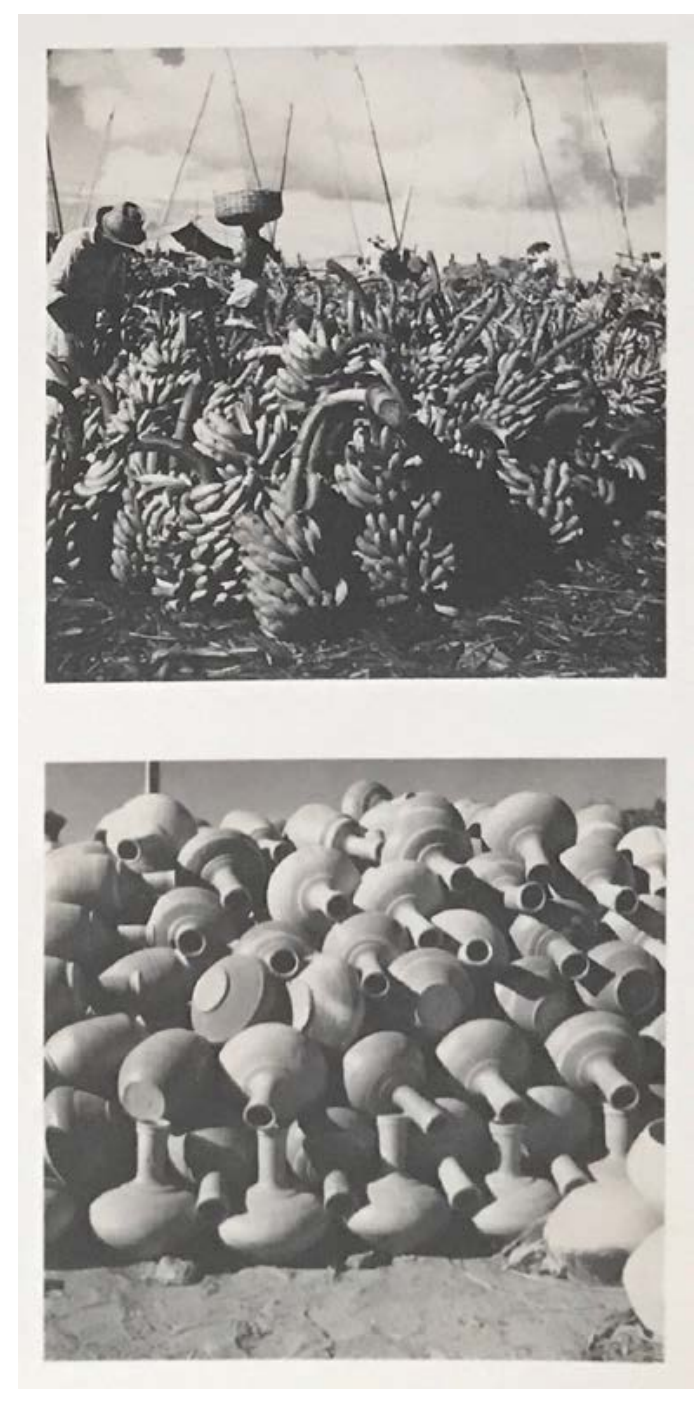

IMG 5.

Salvador, feira de Água dos Meninos. [BARDI, 1957].
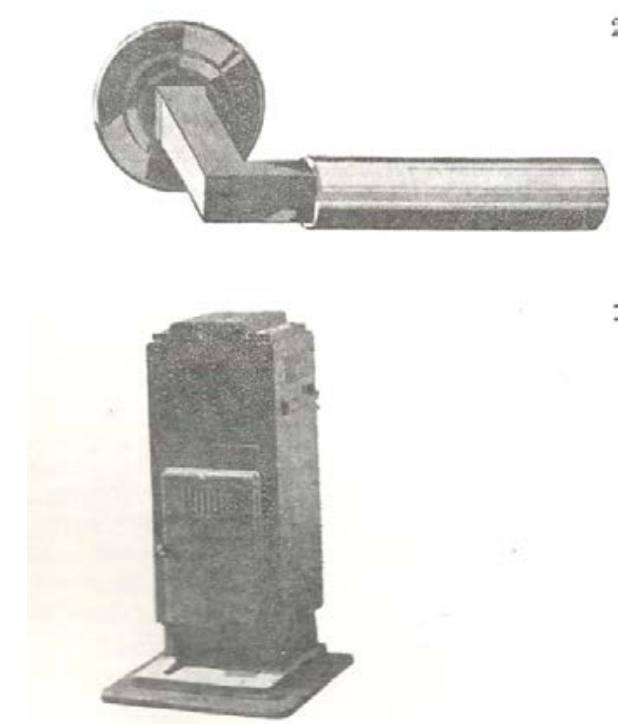

IMG 6.

Maçaneta de níquel (1922) e Calefator (1931).

Walter Gropius. [BARDI,1957:89]
O problema central do ensino de teoria, portanto, estaria centrado no método - "o modo de 'projetar', o meio de aquisição daquele conjunto de noções necessárias, indistintamente, a toda projetação" ${ }^{38} \mathrm{Um}$ meio que, senão a solução dos problemas, seja "instrumento de colocação" dos mesmos. ${ }^{39}$

The teaching of a metod of approach is more important than the teaching of skills. It should be a continuing process which must grow concentrically like the annual rings of a tree. In all its stages the scope should be all-embracing instead of sectional, increasing slowly in intensity and detail in all fields of discipline simultaneously. The integration of the whole range of knowledge and experience is of the greatest importance right from the start; only then will the totality of aspect make sense in the student's mind. He will easily absorb all further details and place them where they belong if he progresses from the whole to the details, and not vice versa. ${ }^{40}$

Das premissas de Gropius ,que dedicou toda sua vida ao ensino, na visão da figura do arquiteto como criador de cultura, ficaria ao ensino a base sólida orientada de forma eficiente pelo "enquadramento num método", ${ }^{41}$ e por "método a capacidade de orientação, de estudo e de apreensão criadora do âmbito cognoscível necessário à ciência (em nosso caso a Arquitetura) e à vida, afim de se chegar àquela auto-disciplina intelectual e autonomia moral que deveriam ser, sobretudo em sua fase inicial, prerrogativas da Escola, nunca abandonadas ao léu da vida prática. Todo ensino baseado em teorias abstratas, que prescindem do homem, ignorando sua presença e seu trabalho, única fonte real de toda transformação da natureza e da sua própria documentada pela história - constitui um método que só pode conduzir a resultados vagos e insatisfatórios". ${ }^{42}$

\footnotetext{
$38, p .56$

39, p.39

40 Walter Gropius, Scope of Total Architecture. New York, 1943; p.45 e segs. In: BARDI, Lina Bo. Contribuição propedêutica ao Ensino da Arquitetura. São Paulo: op.cit., p.57.

41 BARDI, Lina Bo. Contribuição propedêutica ao Ensino da Arquitetura. São Paulo: op.cit., p.71.

42 Ibidem, p.58.
} 
Hoje, todavia, o verdadeiro e único centro que possa e deva surgir uma orientação no tocante à Arquitetura é simplesmente a Escola, com tudo o que ela implica no sentido da livre pesquisa da discussão e intercâmbio intelectual, fontes estas extremamente importantes da atividade dos atuais e dos futuros arquitetos, em fecunda oposição a todas as atitudes dogmáticas e constrangedoras das faculdades criadoras do homem. ${ }^{43}$

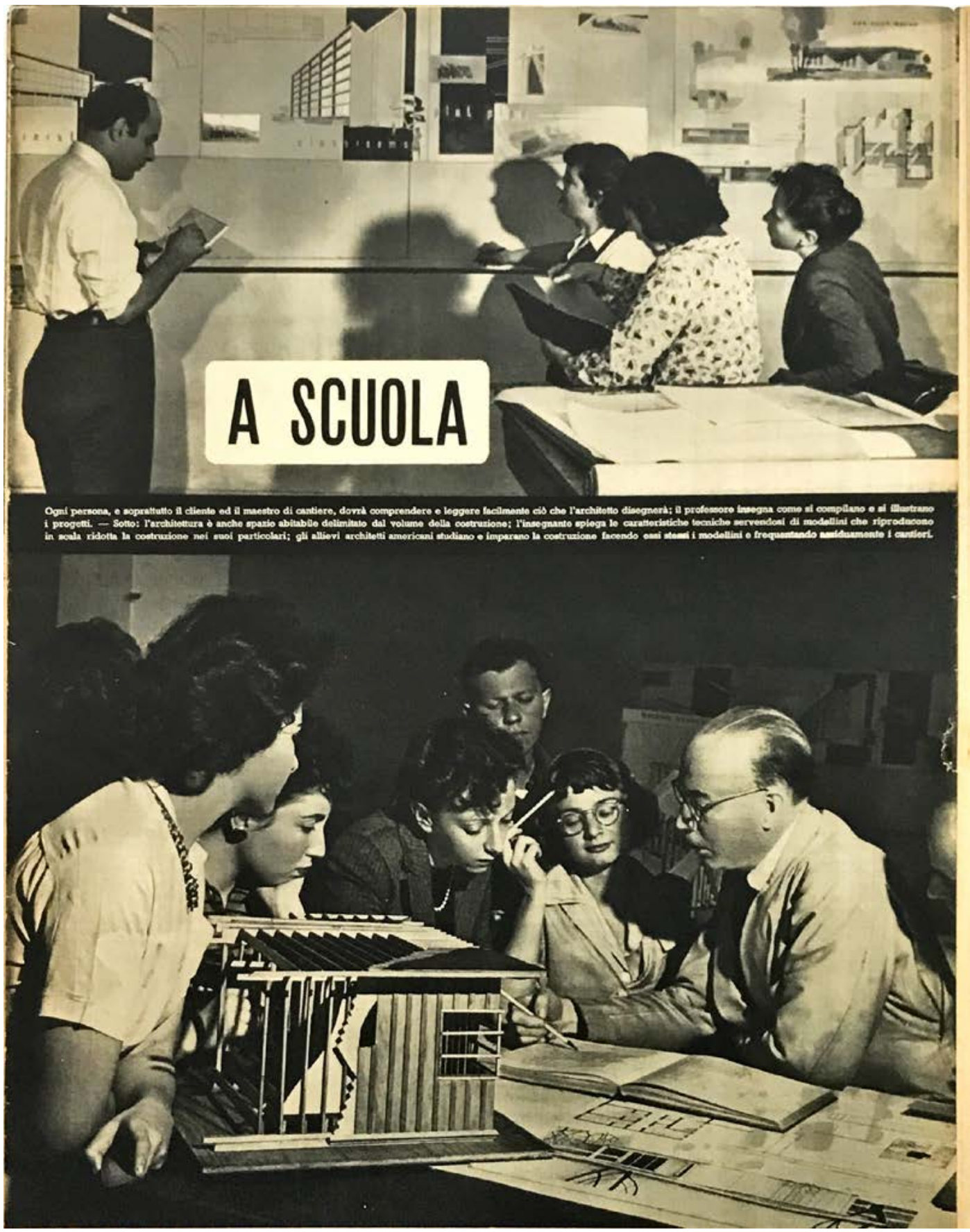

IMG 7.

A Scuola. [Revista A, 1946]. 




\section{As heranças são pesadas, e as 'não-heranças' [...] perigosas. ${ }^{44}$}

No âmbito da teoria literária e literatura comparada, Wille Bolle, no livro grande sertão.br: o romance de formação do Brasil, apresenta os desdobramentos da campanha de Canudos na direção de organizar o território brasileiro, como um epítome que se prolonga fora de Os Sertões e inaugura uma tradição ensaística de retratos do país. Para o autor, Grande Sertão: Veredas é alçado à condição do grande romance na linha de continuidade dessa tradição de matriz sociológica, numa experiência de linguagem, inclusive, que transcende os limites do conteúdo - e também da forma, recriando o próprio signo, ao reinventar uma linguagem capaz de conectar letrado e iletrado. E, na invenção da própria língua, transforma o imenso monólogo em diálogo construído. Lina Bo Bardi, por sua vez, diria que "não existem homens absolutamente incultos, a linguagem do povo não é a sua pronúncia errada, mas a sua maneira de construir o pensamento". ${ }^{45}$

Ao aproximar as miradas pelo sertão do Brasil sob as perspectivas de Euclides e Rosa, Bolle sintetiza que "enquanto o ensaísta-engenheiro sobrevoa o sertão como num aeroplano, Rosa caminha por ele como uma estrada-texto. Ou então ele atravessa o sertão como um rio" ${ }^{46}$

44 BARDI, Lina Bo. Contribuição propedêutica ao Ensino da Arquitetura. São Paulo: op.cit., p.50.

45 Id. Museo di Arte di San Paolo del Brasile. Architettura. Cronache e storia, n.210, Milão, abr. 1973:779.

46 BOLLE, Wille. Grandesertão.br - O romance de formação do Brasil. São Paulo: Duas Cidades; Ed. 34, 2004, p.76. 
Do construtivo-popular, em franca inserção no processo de desenvolvimento industrial nos anos 1950 em São Paulo, à experiência na Bahia, cuja potência popular é vista como instrumento de autenticidade do país, Lina projeta os Brasis antevistos por ela em sua práxis. E assim, do primitivo - distante - que embaralha o tempo e pode ser, na mesma mirada, primitivo e contemporâneo, ao popular - próximo; do sobrevoo à altura do olho que se aproxima, se ambos - primitivo e popular - carregam um gesto ético contido no fazer [e não seria essa a própria definição de ética?] - já não podem salvar a todos. A sociedade preconceituosa, reacionária, inculta e, sobretudo, cindida, pois ainda que não represente a todos, precisa ser salva. Mas é exatamente quando esse "outro" deixa de ser uma ingênua abstração poética, nessa passagem que dá corpo a teoria em ato, esse movimento que torna próximo, sem idealizações, e escancara o "aproveitável" - essa é a potência. É a ética reivindicada por Lina. É a teoria que se faz junto, da moral que se desloca do outro pra si.

Não somos fautores da casa de 'pau a pique' nem tampouco da cultura anteposta ao fato criativo arquitetônico; o que reputamos necessário, hoje em dia, é um justo meio, e pois nem o 'dogmatismo' nem o 'impressionismo', mas uma espécie de medida, naturalmente crítica que, levando em consideração a história como herança e continuidade, abra as mais amplas liberdades às possibilidades do arquiteto, hoje mais do que nunca mediador responsável pelo 'modo de viver' dos homens. E como pensamos que a escola tem a responsabilidade da cultura, estamos convencidos da necessidade, para um professor, de uma posição que não seja dogmática, embora sendo decidida, quase 'dura' com respeito a certos problemas, e que se caracterize pela flexibilidade à qual aludimos, e por uma compreensão elástica, do ponto de vista humano, e extremamente rigorosa do ponto de vista científico construtivo, e de extrema intransigência no tocante àquela atitude profissional que - não levando em conta as discussões que o termo pode suscitar - denominamos 'moral'. ${ }^{47}$

47 BARDI, Lina Bo. Contribuição propedêutica ao Ensino

Bule feito de lata de manteiga. [Arquivo ILBPMB] 


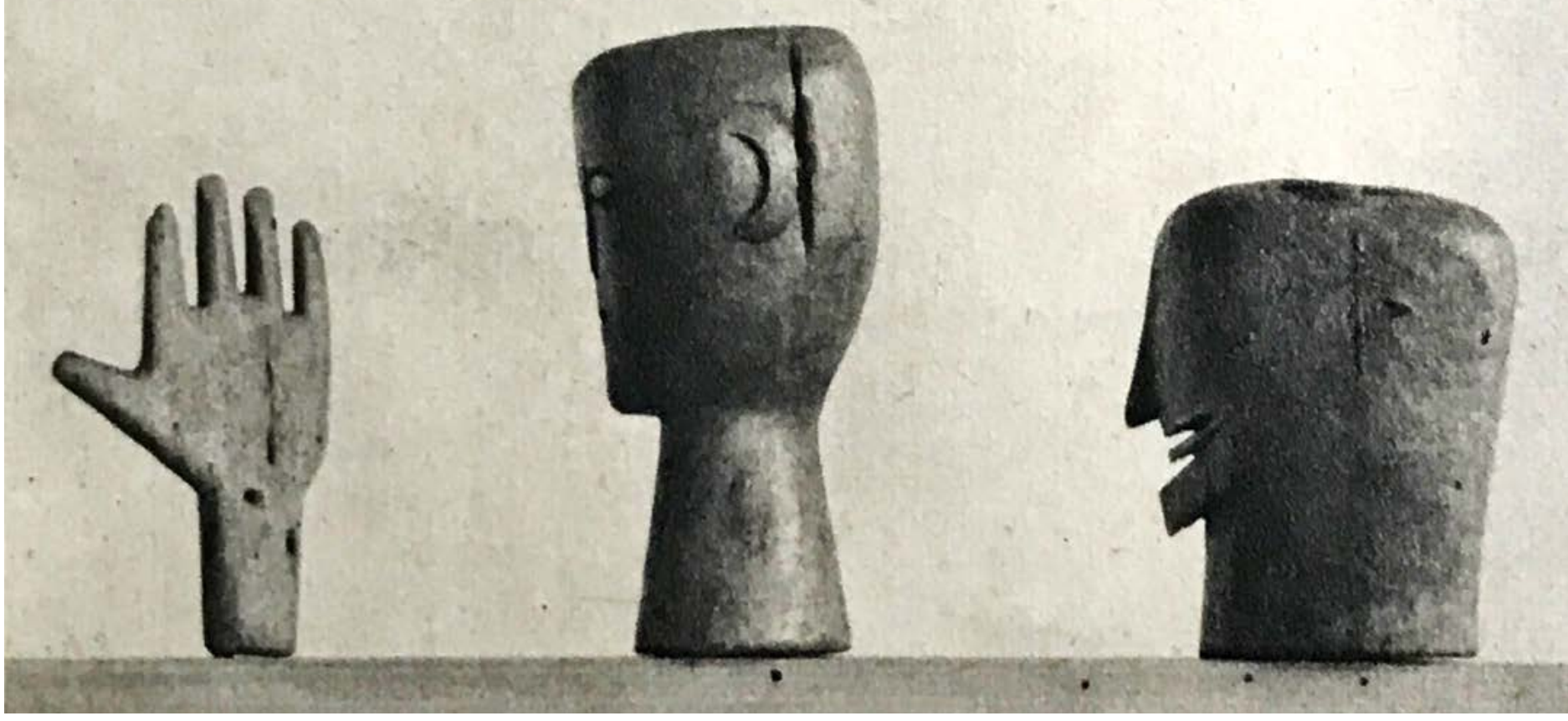

Ao enfrentar o processo de industrialização brasileira no contexto pós-Brasília, Lina formalizaria uma abordagem metodológica que sinalizasse vias possíveis de desenvolvimento do país, no horizonte da capacidade técnica-industrial, por meio das práticas culturais e populares ligados ao mundo moderno. Sua práxis constitui, assim, matéria viva, alternativa ao modelo de industrialização adotado no país a partir da década de 1950, pautada no reconhecimento das particularidades da situação social e política e, sobretudo, atenta às contradições locais que estão no bojo do processo de industrialização brasileira.

Diante do bívio em que escolhemos a contra-mão da finesse (e, portanto, da abertura indiscriminada aos objetos de consumo), interessa aqui o ponto da encruzilhada que colocava o design no impasse, o passo atrás imbuído da possibilidade de regeneração da sociedade pelo desenho industrial, antes de ser tomado como "a mais estarrecedora denúncia da perversidade de todo um sistema capitalista". ${ }^{48}$

Interessa, portanto, redimensionar os termos de origem e chegada nas reflexões de Lina e na conceituação de seus termos, mapeando um compêndio de conceitos preliminares, daquilo que para ela seria nossa natureza constitutiva: a Grossura. Derivada, assim, das possibilidades formais do nosso processo de simplificação, sinalizaria para a construção pedagógica de uma cultura industrial indutora de um progresso técnico-social, então "aderente às necessidades reais do país". ${ }^{49}$

O que é preciso é valorizar certas coisas simples que são a nossa realidade. Eu acho que o Brasil é um país oriental, a África é oriental e São Paulo é um incidente ocidental na história do Brasil. São Paulo não é o Brasil. E quando se faz industrial design, acrílicos, essas competições todas, debates estéticos, a gente esquece que - Brasil é uma outra coisa, é um grande país...Eu estive fazendo um trabalho na beira do rio São Francisco, em Propriá, na comunidade de Cumurupim. Eu vi lá coisas maravilhosas, desde o trabalho de trança de pescadores, até certos móveis que estão feitos utilizando-se somente sarrafos justapostos, parece um trabalho japonês. Isso não é nem artesanato nem coisa nostálgica, é coisa do povo, é um convite a um grande levantamento nacional para se pesquisar as nossas verdadeiras necessidades..$^{50}$

da Arquitetura. São Paulo: op.cit., pp.50-51

48 SUZUKI, Marcelo. (org.). Tempos de Grossura: o design no impasse. São Paulo: Instituto Lina Bo e P. M. Bardi, 1994, p.13.

49 Ibidem

50 MENEZES, Aureliana. Entrevista com a arquiteta Lina Bo Bardi. FAU-USP, 20 de agosto de 1976. Arquivo ILBPMB.

IMG 9.

Objetos Exposição Bahia, 1959 [Domus n.284, 1953:26]. 


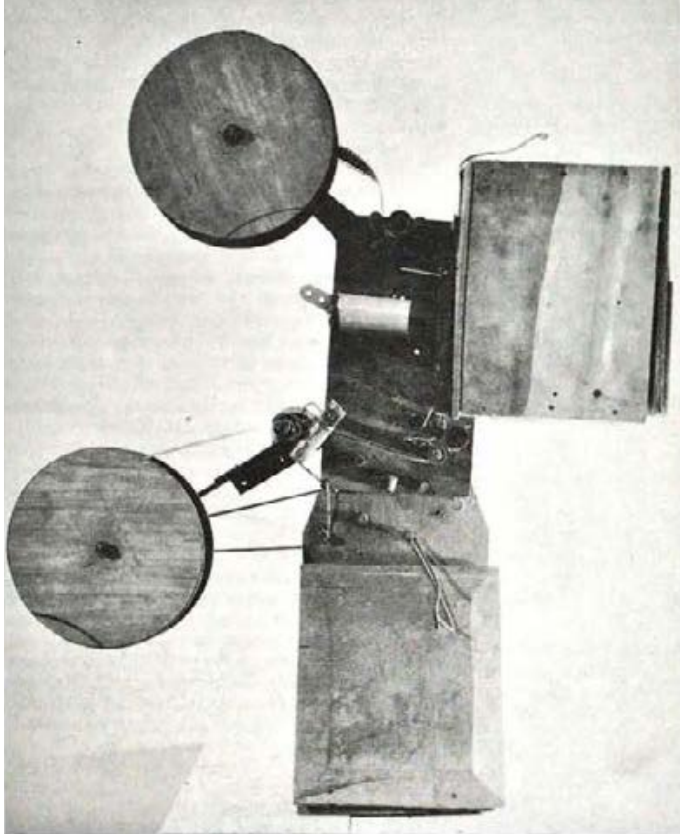

IMG 10.

Projetor de madeira, arame e flandre, 1960

[Malasartes, n.2, jan/fev/mar 1976]

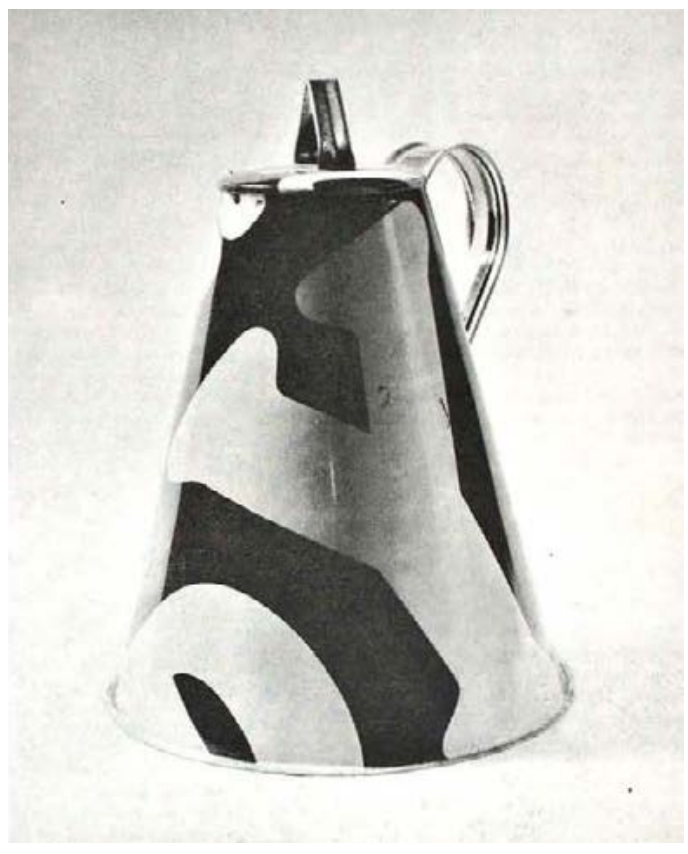

IMG 11.

Bule de flandre de lata de Toddy, Caruru, PE, 1960. [Malasartes, n.2, jan/fev/mar 1976]
Da precariedade "dura e grossa", uma linguagem própria desvinculada da cultura de massa americana e europeia que seria alcançada a partir da digestão de um universo simplificado. Em suas palavras, "Não foi um programa ambicioso, era apenas um caminho". ${ }^{51}$ Nessa direção, Lina escreveria um conjunto de artigos relacionando técnica, arquitetura e desenho industrial, na chave da emancipação social via consolidação de uma linguagem técnica industrial e seu processo de transmissão, através do fortalecimento de uma cultura industrial. ${ }^{52}$

Sua visão sobre o pré-artesanato tem muito do sentido de se demonstrar a inteligência e a capacidade criativa para superar dificuldades, de forma tal que dessa demonstração contestava as proposições da indústria contemporânea onde a obsolescência dos produtos estava sendo substituída pelo descartável, no consumismo e inutilidades e supérfluos como gadgets, a hipocrisia intelectual contida nas expressões kitsch e folklore. ${ }^{53}$

Era preciso "resolver suas contradições internas," ${ }_{54}$ problema que atravessa, no Brasil, a própria concepção de industrial design e sua vinculação - embora evidente não menos conflituosa - com o modo de produção, entendendo os debates acerca da condição de subdesenvolvimento do país e o papel do Estado na industrialização, face ao acentuado descompasso entre regiões e mesmo os diferentes estágios de industrialização entre os países, muitas vezes em suas próprias fronteiras imediatas. Haveria limites sociais, artísticos e, consequentemente, produtivos nesse processo em consolidação de uma cultura de massa para uma sociedade de consumo?

A sociedade industrial se desdobraria na integração do indivíduo ao sistema de

51 Lina Bo Bardi. "Cinco anos entre os brancos", em Mirante das Artes, Etc, n.6, nov., 1967:18.

52 Do material presente no livro Tempos de Grossura, organizado pelo seu colaborador Marcelo Suzuki, somamse os acervos dos arquivos Instituto Lina Bo e Pietro Maria Bardi, MASP e Museu de Arte da Bahia, além do trabalho Lina por escrito. Textos escolhidos de Lina Bo Bardi, organizado por Marina Grinover e Silvana Rubino. 53 SUZUKI, Marcelo. Lina e Lucio. Tese de Doutorado. IAU-USP, 2010, p. 267.

54 MENEZES, Aureliana. Entrevista com a arquiteta Lina Bo Bardi. FAU-USP, 20 de agosto de 1976. Arquivo ILPMB. 


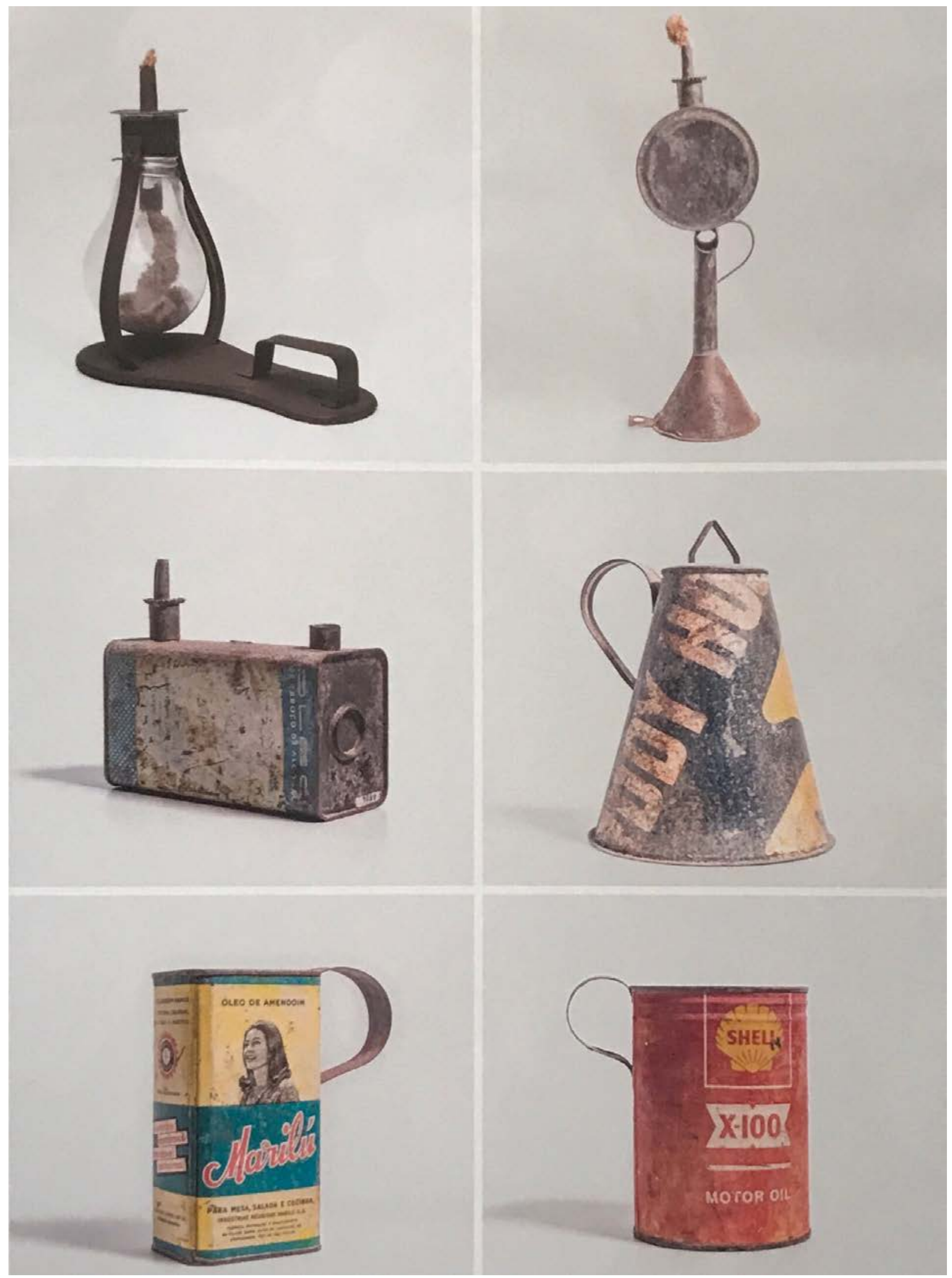


produção e consumo, a partir de uma necessidade programada e reproduzida pela eficiência de um sistema que se retroalimentava da alienação perante o fenômeno da cultura de massas e dos condicionantes de exploração inerentes à produção material. Tais problemáticas atravessavam o desenho industrial. Para Argan, "a reprodução em série torna-se o processo intrínseco da ideação formal (...) e o problema da arquitetura já não se coloca ao nível do particularismo dos edifícios, mas sim ao de um sistema produtivo que vai desde a pré-fabricação até o urbanismo". ${ }^{.55}$ A crítica que se avolumava em torno do binômio produção-consumo, passava, portanto, necessariamente pela revisão dos valores válidos na sociedade ocidental. ${ }^{56}$

Especialmente no Brasil, as duas pontas do sistema produção e consumo são marcadas por implicações sociais derivadas das extremas desigualdades regionais, intensificando esse duplo movimento que aliena e explora, no universo do trabalho e da terra. Lina está inscrita neste período agudo de uma frágil associação entre desenvolvimento e industrialização que aponta, necessariamente, para os limites da estrutura social brasileira, de matriz escravocrata-senhoril, cujo impacto seria imediato na racionalização dos processos produtivos $\mathrm{e}$ na fratura entre prática projetual e meios de produção, que marca a idiossincrasia do projeto moderno em solo nacional.

Evidente que um empreendimento público da envergadura de Brasília, acabaria por evidenciar a problemática relação entre arquitetura e indústria no país, ao construir em grande escala e curto prazo, levando ao limite os raciocínios de produção em série, como racionalização e mecanização dos métodos e processos construtivos, modulação de elementos e repetição. Logo, da problematização das relações entre produção e trabalho também seria colocada a partir do canteiro. ${ }^{57}$

Ciente de que o "desenvolvimento histórico não significa, com efeito 'conciliação', e sim exame crítico profundo e sempre presente, [...] indispensável para não se cair na abstração formalística", ${ }^{58}$ Lina chamaria a atenção para, tampouco, $o$ fato de que "naturalmente, libertar-se da escravidão do passado não significa ignorar o passado". ${ }^{59}$ Assim, tendo em vista de que os artesãos - ou "pré-artesãos" - não são operários, e tampouco os escravos os foram, quais as formas de organização social produziram a nossa vida material?

E, nesta "história em ato - a história do trabalho e da fadiga do homem", ${ }^{\circ 0}$ o desenho da necessidade antevisto por Lina como potência reside especialmente no fato de se confrontar com o desenho da necessidade do homem que produz sua própria vida material. E, sendo ele o protagonista da "aventura arquitetônica [...] uma aventura 'útil' ao homem, cessando de ser Arquitetura no momento em que deixa de ser útil". ${ }^{61}$

Para esta arte, - que durante séculos foi antes expressão de mitos e de ideias políticas do que motivo de satisfação e conforto objetivo, - se torne um benefício de todos e para todos, o ponto de partida deverá consistir em exprimir e interpretar aspirações e necessidades materiais do próximo e não apenas sua máscara - especialmente das classes que, por motivos históricos, necessitam maior consideração. Nesse sentido, a extravagância e o desperdício, a renúncia às ideias contemporâneas, e a passiva aceitação de fórmulas passadistas são fatores a serem considerados, evidentemente, como elementos negativos e fontes de erro. ${ }^{62}$

O olhar estrangeiro de Lina rearticula para circunstância brasileira um lugar central

\footnotetext{
55 ARGAN, Walter Gropius e a Bauhaus, p.42.

56 ARGAN, 1983, p.157

57 Cf. FERRO, Sérgio. Arquitetura e trabalho livre. São Paulo: Cosac Naify, 2006.

58 BARDI, Lina Bo. Contribuição propedêutica ao Ensino da Arquitetura. São Paulo: op.cit., pp.69-70.

59 Ibidem,p.10

60 Lina Bo Bardi. Manuscrito editado da primeira aula no curso de arquitetura da Faculdade de Belas-artes da Universidade Federal da Bahia em 1958. In: RUBINO,S.;GRINOVER,M. (orgs.). Lina por escrito. Textos escolhidos de Lina Bo Bardi. São Paulo: op.cit., p.84.

61 Id. Contribuição propedêutica ao Ensino da Arquitetura. São Paulo: op.cit., p.43.

62 BARDI, Lina Bo. Contribuição propedêutica ao Ensino da Arquitetura. São Paulo: op.cit., p.48.
} 


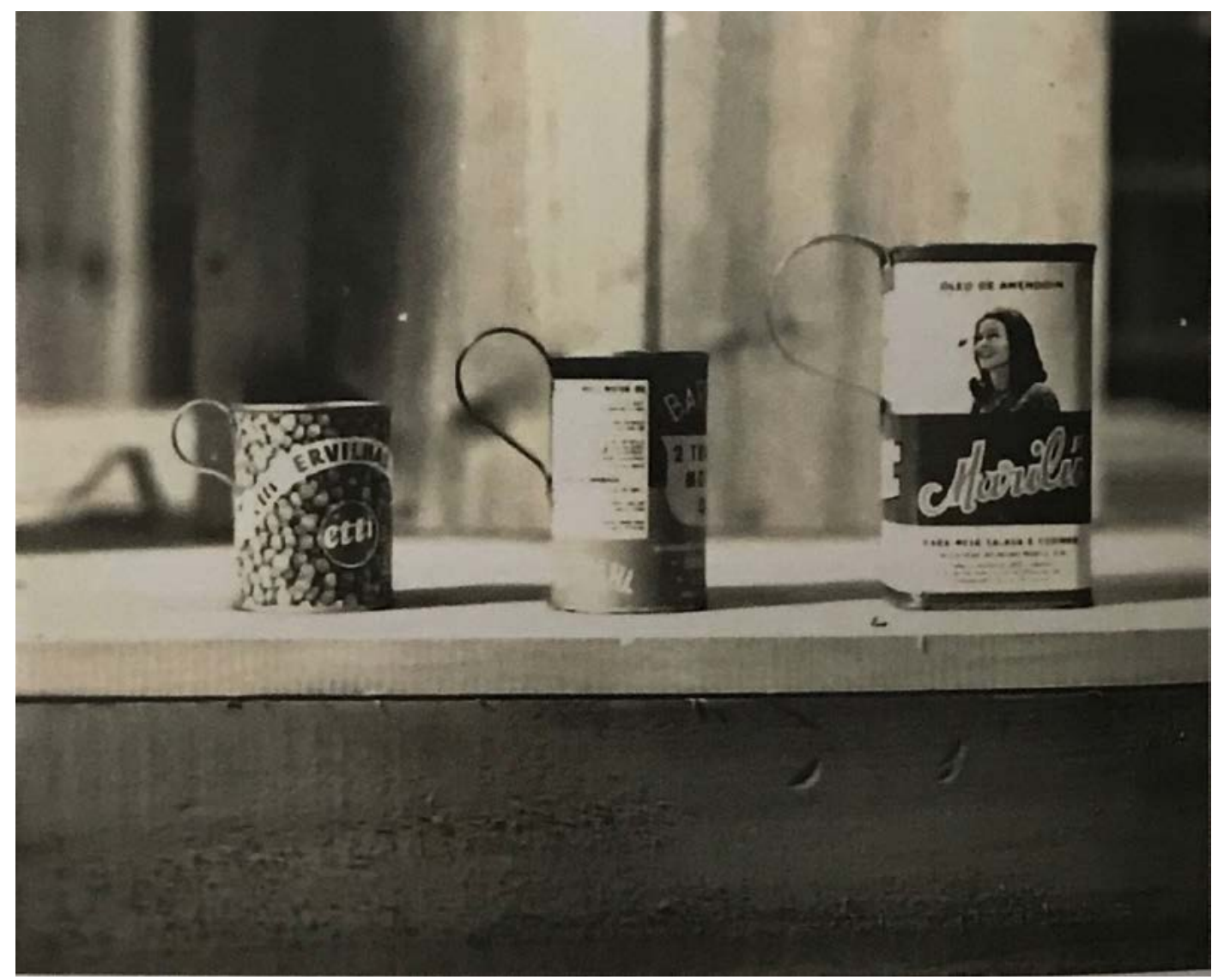

IMG 18.

para produção popular como força motriz no desenvolvimento de uma cultura, no Canecas Lata, Expo A mão do Povo, 1969 [Arquivo MASP]. caminho de enfretamento de uma herança colonial através da valorização da experiência popular, equacionando o contexto internacional às especificidades locais muito além do "fazer bananas, mulatas, papagaios e tucanos". ${ }^{63}$

No campo pedagógico, sobre a formação do desenhista industrial, Lina apontaria: "Primeiro, uma formação sociológica, antes de tudo. Sócio-política. Para compreender a situação do país no qual ele desenvolve ou irá desenvolver sua atividade. Sem compreender completamente a situação do próprio país não se pode fazer desenho industrial." ${ }_{64}$

63 PIGNATARI, D. In: Abstracionismo Geométrico e Informal, a vanguarda brasileira nos anos cinquenta, Funarte, Rio de Janeiro, 1987, p. 76.

64 MENEZES, Aureliana. Entrevista com a arquiteta Lina Bo Bardi. FAU-USP, 20 de agosto de 1976. Arquivo ILPMB. 
Eu vou lhe dizer: o povo cria. Eu me ocupei, muitos anos atrás, do problema da sobrevivência do povo nordestino. É um povo que saindo do lixo, completamente abandonado, sem nenhum recurso, conseguiu criar do lixo todo um modo de viver, de objetos, de coisas, não de decoração, não são as cerâmicas não, não estou falando daquilo não, das belezinhas... Coisas assim como colchas, brinquedos, copos, panelas, garfos, colheres, até privadas. Eu consegui uma belíssima privada que não tinha encanamento nenhum (de Águade-Meninos) e que expus na Exposição Civilização do Nordeste que inaugurou - Museu de Arte Popular do Unhão, na Bahia, em 1963.[...] Então o homem tem em si a capacidade de ser criativo, não é necessário que essa capacidade seja despertada por aulas ou por outros artifícios." 65

Nesse caminho "aproveitável" para o design a partir das criações do povo, era necessário sistematizar sua construção de um método que culminaria, necessariamente, no programa de uma escola - afinal quais categorias serviram à passagem do então pré-artesanato ao desenho industrial?

Atenta às contingências de nossa produção industrial, Lina empenhou-se em traduzir, na prancheta, os códigos capazes de representar o agudo raciocínio de uma modernidade ambivalente. Sua ação cultural no Nordeste vai de um museu de arte moderna (MAMB) a um museu de arte popular (MAPU) - em equivalência - é importante ressaltar, fomentando nesse processo um centro de estudos sobre o trabalho artesanal (CETA), do qual deriva, ainda, uma escola de desenho industrial. Essa linha continuada e recíproca entre instituições, interroga as potencialidades do que define a cultura brasileira; a força da cultura popular do nordeste do Brasil abriria um campo de autenticidade e resistência, formalizada em uma linguagem mais comprometida aos contextos sociais e suas práticas. Lina faria jus à responsabilidade coletiva de sua atividade profissional, cujas teorias responderiam às condições ambientais, morais e sociais, em direção a

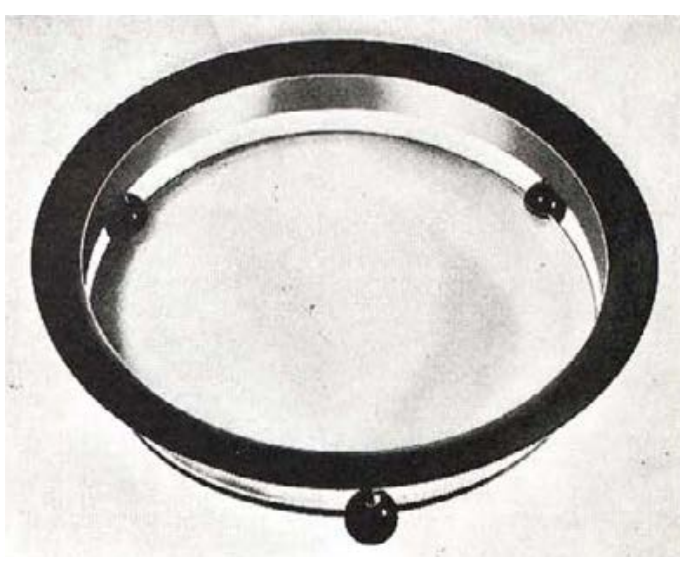

IMGS 19-20.

Fruteira Albers, 1923 e Jogo de panelas, Sambonet, 1965 [Malasartes, n.2, jan/fev/mar 1976]

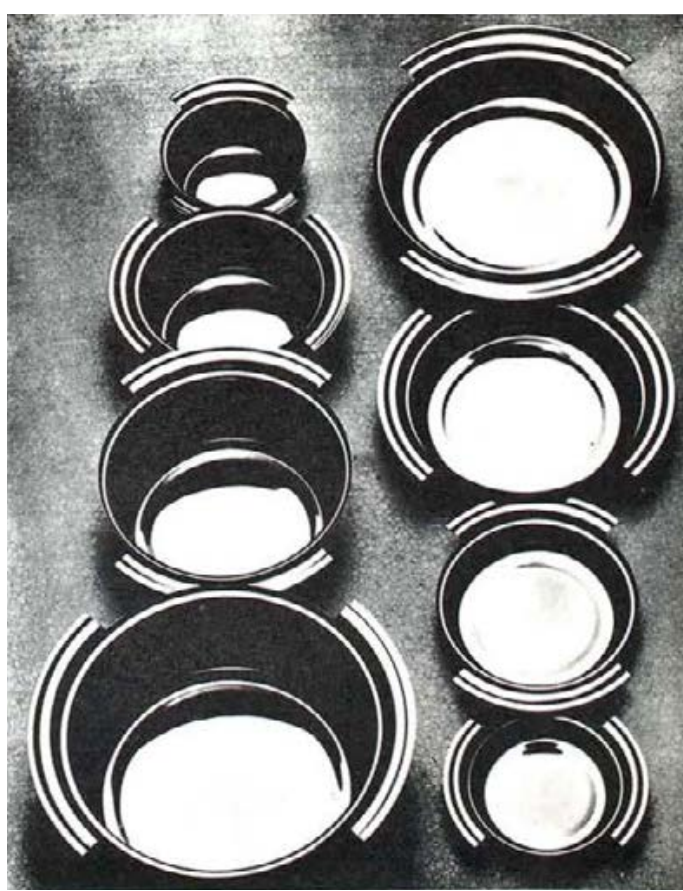


"indagação efetiva e nas necessidades [do] país". ${ }^{66}$

[...] esta força latente existe em alto grau no Brasil, onde uma forma primordial de civilização primitiva (não no sentido de ingênua, e sim composta de elementos essenciais, reais e concretos) coincide com as formas mais avançadas do pensamento moderno. ${ }^{67}$

Entendendo a teoria no bojo da experiência de simplificação, desdobrada em sua experiência na Bahia, essa tese busca retomar a produção de Lina Bo Bardi, nas práticas institucionalizadas por ela, nos três primeiros museus que concebeu - MASP, MAMB e MAPU - procurando identificar os conceitos-chave que balizaram suas ações pedagógicas, que culminariam no projeto da Escola de Desenho Industrial e Artesanato, na Bahia, em 1963. Tal projeto, que buscou uma aproximação com a recém-criada SUDENE, sintetizaria seus esforços acerca do enfrentamento dos paradoxos do processo de industrialização brasileira no desenvolvimento de um método capaz de produzir, reproduzir e, logo, transmitir, uma cultura material industrial vinda da simplificação. O título - Propedêutica da Grossura - condensa a hipótese do trabalho de que, a partir de um corpo preliminar teórico construído em ato por meio das práticas pedagógicas, Lina buscaria sistematizar um método derivado do conjunto de conhecimentos preliminares da Grossura, marcados pela inventividade de uma cultura material possível, formalizando, dessa forma, a propedêutica da grossura como práxis.

Lina vai acirrar bastante esse aspecto, posteriormente, aumentando o emprego de métodos primitivos, rudimentares, em suas obras de arquitetura e design, como uma tese para um desenvolvimento diferenciado - mais ainda - do Brasil em relação ao resto do mundo. Dizia que, infelizmente, o sofisticado requinte do trabalho indígena, de altíssima abstração estava irremediavelmente perdido, e que não se podia correr o risco de folclorizar o que sobrara. E que, como vimos, era inatingível o grau de complexidade atingida pelas civilizações orientais, particularmente o Japão, que ela conheceu de perto, e a China maoísta. Então, propunha ser necessário usar o que restara, da técnica acaboclada, lançar mão da grossura. ${ }^{68}$

Se a matriz oriental direcionada aos trópicos era inatingível par se evitar o enorme custo implicado nas consequências do sistema produtivo no mundo ocidental, tal como vinha se apresentando na forma dos gadgets que o afastava de sua cultura, fazia-se necessário rever os termos dessa cultura potencial que, por não estar instrumentalizada dentro de um sistema próprio de produção, seria mais suscetível aos custos implicados nesse processo. ${ }^{69}$

Em um projeto que associava desenho industrial à produção pré-artesanal nordestina, em um esforço de identificar as forças básicas do País, Lina se detinha a uma perspectiva de ensino pautada em uma visão cultural ampla: era preciso levar em consideração a complexidade do processo de industrialização brasileira e a sistematização das dinâmicas tecnológicas e industriais que poderiam ser incorporadas à atividade projetual e codificados em um sistema pedagógico. E neste caminho que vai do pré-artesanato doméstico à construção de um desenho industrial aderente à cultura do país - e para quem o entendimento de cultura passa necessariamente pela compreensão de um sistema cultural próprio - reside a potência da autenticidade de um projeto cuja linguagem viesse de uma matriz bruta e carregada de outras possibilidades.

O Brasil entrou, queira ou não queira, na era da industrialização. E aquilo que era "aproveitável" naqueles anos, hoje é história. Que a página seja virada, e que o esforço continue com a sinceridade que nos pusemos na pesquisa das forças básicas do País. ${ }^{70}$

66 BARDI, Lina Bo. Contribuição propedêutica ao Ensino da Arquitetura. São Paulo: op.cit., p.70.

67 Id. Crônicas de arte, de história, de costume, de cultura da vida. n.1, Diário de Notícias, 1958.

68 SUZUKI, Marcelo. Lina e Lucio. Tese de Doutorado. IAU-USP, 2010, p.92.

69 Lina Bo Bardi, "Progresso e Civilização". In: FERRAZ, M.(org,). Lina Bo Bardi , op. cit.,p. 209.

70 Lina Bo Bardi. Planejamento ambiental: desenho no impasse. Malasartes, Rio de Janeiro, n. 2, p. 4-6, jan/fev/mar 1976. 


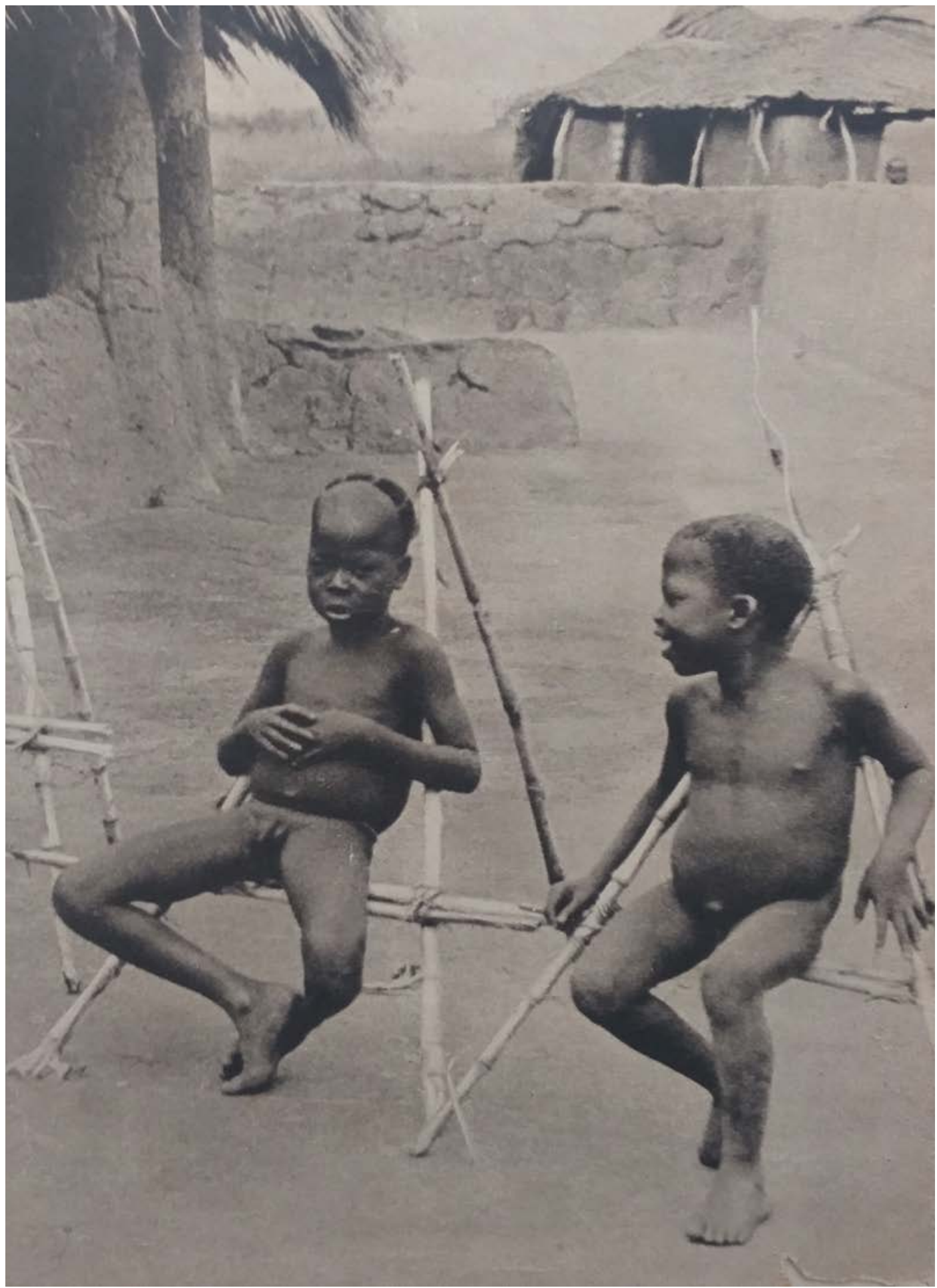

IMG 21.

Cadeira Tribo Africana [Arquivo ILBPMB]. 


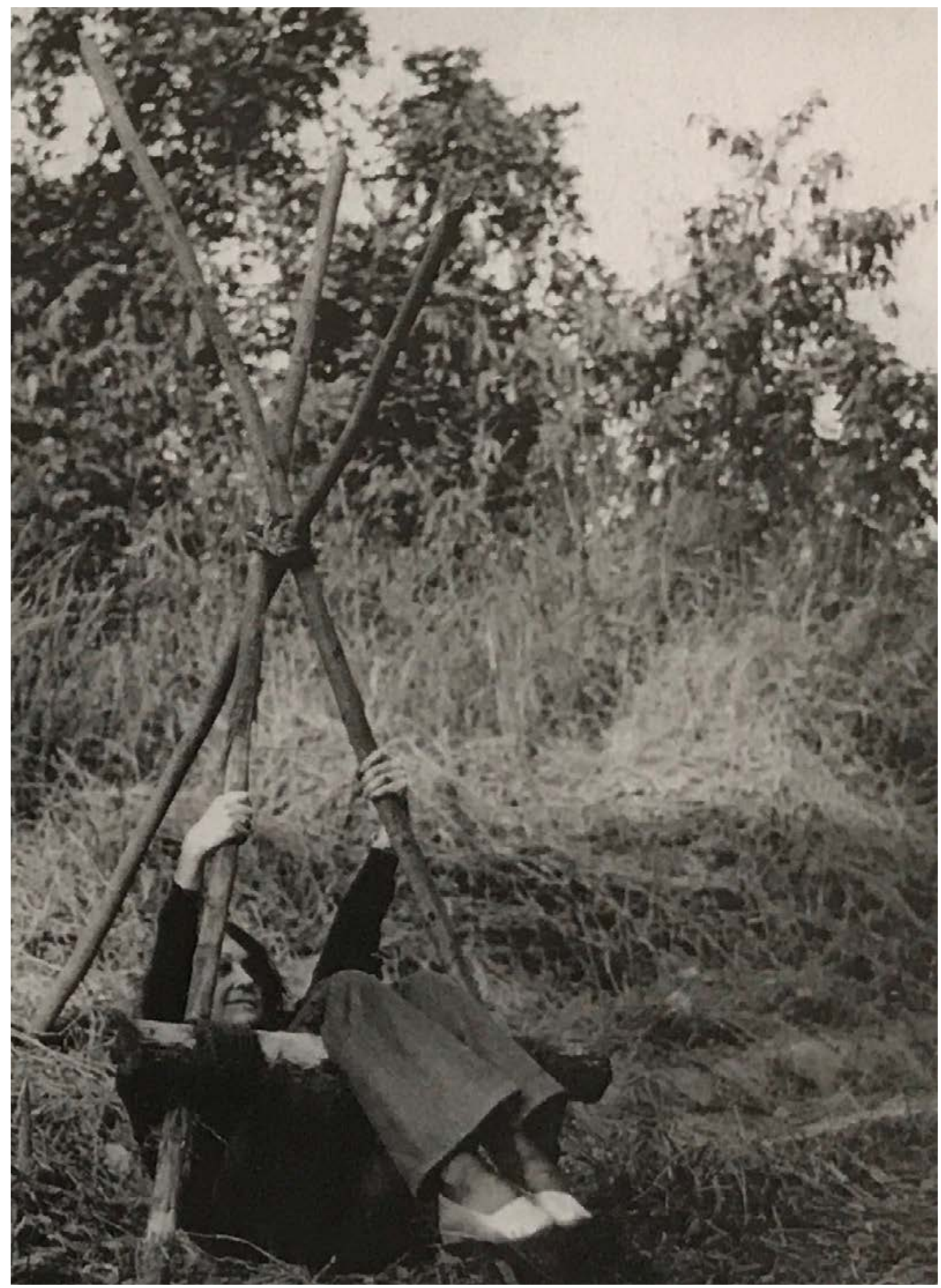

IMG 22.

Cadeira Beira-de-estrada, 1967. [Arquivo ILBPMB]. 


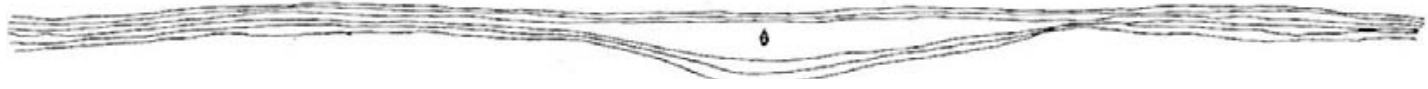

IMG 23.

Brasília: cinco dias. [LISPECTOR, 1978:12] 


\section{PRÁTICAS PEDAGÓGICAS}

\section{MASP}

\section{Os puristas são enfadonhos e inúteis}

Todo o estudo compreensivo da sociedade brasileira há de se destacar o fato verdadeiramente fundamental de constituirmos o único esforço bem sucedido, e em larga escala, de transplantação da cultura europeia para uma zona de clima tropical. ${ }^{2}$

No Brasil, as estratégias de unificar a nação sob um emblema que fosse capaz de defini-la acentuou os esforços, no plano intelectual, em configurar a experiência cultural da paisagem nos trópicos. Mas o suposto éden em vias de modernização é também o espaço natural e hostil, sob o qual a fragilidade da cultura emerge como impasse para o mundo ocidental.

Encaremos o mundo, encaremos a geografia: o mundo vai assumindo nova fisionomia, a geografia vai dificultosamente ganhando ordem, a distribuição dos grupos flutua, à procura do 'ubi consistem'; as grandes correntes humanas deslocam-se, sobrepõem-se, conjugam-se, enlaçam-se, chocam-se, repelem-se. É a época das grandes transplantações. Não uma época aventurosa e heroica. [...] Estamos na época das grandes necessidades humanas, ditadas mais pelo espírito consciente e por misteriosos impulsos da alma dos povos. ${ }^{3}$

Essa espécie de dúvida permanente à

1 Emilio Villa. "Os puristas são enfadonhos e inúteis". Habitat, n.7, prefácio.

2 BUARQUE DE HOLANDA, Sérgio. Raízes do Brasil. 5ed. Rio de Janeiro: 1969, p.3.

3 Emilio Villa, op. cit. 
possibilidade efetiva de um mundo ocidental vem exatamente de um mundo moderno cuja premissa constitutiva seria exatamente o equilíbrio preciso entre civilização e natureza, pautado nesse agir sobre o mundo natural, ou como diria Lévi-Strauss, na construção de uma paisagem que, longe de ser a expressão espontânea da natureza, provinha de "acordos longamente procurados durante uma colaboração entre sítio e homem", ${ }^{4}$ diferente da supremacia das forças naturais sobre o destino dos homens, a quem deveria então "apoiar-se sobre si próprio em todas as circunstâncias da existência". ${ }^{5}$

Antes de ter existência própria, começamos por ser uma ideia europeia [...] $A$ Europa é o fruto, de certo modo involuntário, da história europeia, enquanto nós somos a sua criação premeditada. $\mathrm{Na}$ Europa a real idade precedeu o nome. A América, pelo contrário, começou por ser uma ideia [...] O nome que nos deram nos condenou a ser um mundo novo. Terra de eleição do futuro, antes de ser, a América já sabia como iria ser. Mal se transplantou para nossas terras, o imigrante europeu já perdia a sua realidade histórica: deixava de ter passado e convertia-se em projétil para o futuro [...] Um ser que não tem passado, que não tem mais do que futuro, é um ser de pouca realidade. Americanos, homens de pouca realidade, homens de pouco peso. ${ }^{\circ}$

Le Corbusier apontaria, no seu enfrentamento com o território sul-americano, para a necessidade de uma ação proporcional à escala do território: "[...] no seu país os problemas são tão numerosos, tão imensos, os interiores a colonizar tão grandes, que suas energias diluem-se imediatamente nas dimensões, quantidades e distâncias".? Colonizar aqui, na perspectiva de um europeu seria "tirar-se os chinelos e instigar à aventura. $O$ cientista, o artista, colonizam a cada dia. Descobrir, em conseqüência, revelar. Revelar, em conseqüência mudar a face das coisas. Mudar a face das coisas, agregar um amanhã ao ontem". ${ }^{8}$

Ampliando-se a consciência do hiato entre a realidade concreta do país e as formulações intelectuais da vanguarda ativa brasileira, resultantes dos traumas e singularidades do processo de colonização brasileira, de acordo com Rubino, "resultou um projeto cultural que foi diferentemente interpretado em situações distintas: o de consonância com a industrialização, em que a arquitetura deveria se juntar a essa força transformadora e propor uma nova visualidade e espacialidade com pretensões universais. [...] Isso quer dizer que a arquitetura colocou-se como um campo intelectual, por vezes político, mas, sobretudo, civilizador, colonizador - colonizou a vida cotidiana, participando da construção de um novo olhar, o olhar moderno"?

Não só o questionamento acerca da possibilidade do mundo ocidental nos trópicos estaria no bojo da experiência de Lina ao desembarcar no Brasil em meados do século XX, mas a própria revisão do ocidente no contexto pós-guerra.

Como é o Brasil para o europeu que desembarca pela primeira vez no Rio de Janeiro? Do avião, o contraste entre as favelas e as construções modernas induz mais ao caos social que ao ressentimento burguês pelo arranha-céu padronizado, no lugar da casa de estilo. Do navio, a enseada de Copacabana e a baía com o Ministério da Educação e os outros edifícios que aparecem repentinamente, quase colados na floresta, da qual emana o odor que chega a bordo, sugerem um esforço humano que não deixa tempo para pensar se era melhor o arranha-céu ou a casinha folclórica portuguesa. $^{10}$

4 Lévi-Strauss, Claude. Tristes Trópicos. São Paulo: Companhia da Letras, 1996, p.74

5 Lévi-Strauss, Claude. Tristes Trópicos. São Paulo, op. cit., p.75.

6 PAZ, Octávio. Signos em rotação. Rio de Janeiro: Perspectiva, 1990, p. 127.

7 LE CORBUSIER, "Corolário Brasileiro", 1929, em Precisões sobre um estado presente da arquitetura e do urbanismo. São Paulo, Cosac \& Naify, 2004.

8 Le Corbusier, "O Espírito Sulamericano", 1929. Em SANTOS, Cecília Rodrigues dos [et ali.]. Le Corbusier e o Brasil. São Paulo: Tesseia: Projeto Editora, 1987, p.69.

9 Rubino, Silvana Barbosa. "Gramsci no Museu, ou a arte popular no Solar do Unhão, Salvador 1963-64". Conferencia apresentada na 26a Reunião Brasileira de Antropologia, em Porto Seguro, Bahia, 2008. 10 FERRAZ, M. [org]. Lina Bo Bardi, op.cit., 1993, p.12. 
Consonante às palavras de Le Corbusier, que coloca o estrangeiro como detentor de um senso de exterioridade agudo ao senso crítico, que provém do "saber permanecer em estado julgamento", ${ }^{11}$ Lina demonstra de chegada a leitura crítica que acompanharia toda sua trajetória. Ainda que sua rápida leitura da estrutura social que colocava em xeque o desenvolvimento entre natureza e cultura e, logo adiante, já se mostraria como ponto nevrálgico de suas ações, Lina entende a paisagem apreendida como "primeira mensagem de paz após o dilúvio da Segunda Guerra Mundial. [...] num país inimaginável, onde tudo era possível". ${ }^{12}$

Deslumbrada por um país que supunha possuir uma estrutura social marcada por "duas grandes aristocracias: as das Terras, do Café, da Cana, e ... o Povo", ${ }^{13}$ muito além das dificuldades de adaptação dos indivíduos sob o ambiente hostil, em que "tudo seria absorvido por esta paisagem violenta e sublime", ${ }^{14}$ seriam as consequências do predomínio do escravismo nos países colonizados, obstáculos para a aplicação da ideia-força contida no termo povo-nação. Pois, ao perspectivar a nação no reconhecimento de seu povo, no caso brasileiro, tal chave implicaria que a elite passasse a se reconhecer nos escravos. ${ }^{15} \mathrm{E}$, afinal, quais eram as efetivas possibilidades de conciliação entre elite e povo?
Diante da construção da nacionalidade, nos moldes do Estado e da Civilização, o povo então "inculto" poderia ser incorporado a um processo civilizatório que recusava a reconhecê-lo em sua história? A esse povo "desaforado, ordinário, maravilhoso [...] cafajeste, elegante", ${ }^{16}$ Lina dedicaria sua produção mais substantiva: a constituição de um projeto cuja linguagem pertenceria a todos, advertindo sempre aos seus pares: "não se curvem ao falar com as massas, senhores intelectuais, endireitem as costas". ${ }^{17}$

$\mathrm{Na}$ sociedade duramente estratificada, submetida à brutalidade de uma dominação baseada na escravidão, se de um lado os escritores e intelectuais reforçam os valores impostos, puderam muitas vezes, de outro, usar a ambiguidade do seu instrumento e de sua posição para fazer o que é possível nesses casos: dar a sua voz aos que não poderiam nem saberiam falar em tais níveis de expressão. ${ }^{18}$

Uma vez que os conceitos de civilização e progresso nem sempre seriam coincidentes, Lina apontaria a necessidade da arte popular estar associada a ideia de civilização, haja visto seu entendimento do termo enquanto "o aspecto prático da cultura, $[\ldots]$ a vida dos homens em todos os momentos". ${ }^{19}$

11 LE CORBUSIER, "Corolário Brasileiro", 1929, em Precisões sobre um estado presente da arquitetura e do urbanismo. op.cit., p.26.

12 FERRAZ, M. [org]. Lina Bo Bardi, op.cit., 1993, p.12.

13 lbidem.

14 LE CORBUSIER, "Corolário Brasileiro", 1929, em Precisões sobre um estado presente da arquitetura e do urbanismo. op.cit., p.26.

15 Diante do dilema, a intelligentsia brasileira reelabora, assim, o "tabu em totem". Ver NUNES, Benedito. "A antropofagia ao alcance de todos". Em ANDRADE, Oswald. A utopia antropofágica. São Paulo, Global, 1995.

16 FERRAZ, I. G. e MICHILES, A. Lina Bo Bardi. Documentário em VHS. São Paulo: Instituto Lina Bo e P. M. Bardi, 1993.

17 Lina Bo Bardi. "Cultura e não cultura". Em Crônicas de arte, de história, de cultura da vida. Arquitetura. Pintura. Música. Artes Visuais. Página dominical do I Salvador, n.1, 7 set. 1958.

18 Antônio Cândido. "Literatura de dois gumes". em A Educação pela noite e outros ensaios. 3. ed. São Paulo: Ática, 2000, p. 109.

19 Lina Bo Bardi, "Civilização do Nordeste", em Tempos de Grossura: o design no impasse, op. cit., p. 35. 


\section{Modigliani em New York}

Pela primeira vez um Museu brasileiro, vai enviar uma tela de seu acervo a um certame estrangeiro. E o que se dá com o "Retrato de Zborowsky", de A. Modigliani, pedido pelo "Museum of Modern Art" ao "Museu sem adjetivos", na ocasião da grande exposição dedicada ao mestre italiano, a se realizar em New York e Cleveland.

IMG 24.

Modigliani em New York. [Habitat n.1, p.92] 


\section{Agenda Didática}

Com o fim da II Guerra Mundial, o conceito de museu seria reformulado, a partir das antigas instituições europeias em ruínas e o MoMA se tornaria uma referência em termos de institucionalização do patrimônio recente para além do conceito histórico, pautadas em ações de grande alcance pedagógico, provocando o deslocamento dos circuitos seculares de acesso à cultura, agora do outro lado do atlântico. ${ }^{20}$

Uma agenda didática moderna e experimental seria resultante dessa reformulação que se irradiava no âmbito da comunicação dirigida então à cultura de massa. As exposições realizadas no MoMA expandiam as fronteiras da arte, incorporando múltiplas manifestações, das artes plásticas às artes aplicadas, gráficas, tipográficas, industriais, populares, arquitetônicas, passando pelos movimentos do corpo, no teatro e na dança.

Durante a Segunda Guerra Mundial, o governo dos Estados Unidos empenhou-se no fortalecimento de laços diplomáticos com as repúblicas americanas, diante das ameaças de expansão nazista e propaganda anti-americana, através da implementação de um protocolo de segurança denominado "Política de boa vizinhança", ${ }^{21}$ cujas ações se estenderiam a diversos campos, da indústria à educação, na forma de um intercâmbio cultural.

20 Maria Cecília França Lourenço, Museus acolhem moderno. São Paulo: E.D.U.S.P., 1999, p. 21

21 Ver Lauro Cavalcanti, "A arquitetura do Bom Vizinho", em Moderno e brasileiro, a história de uma nova linguagem na arquitetura 1930-1960, op. cit., pp.165-171. 

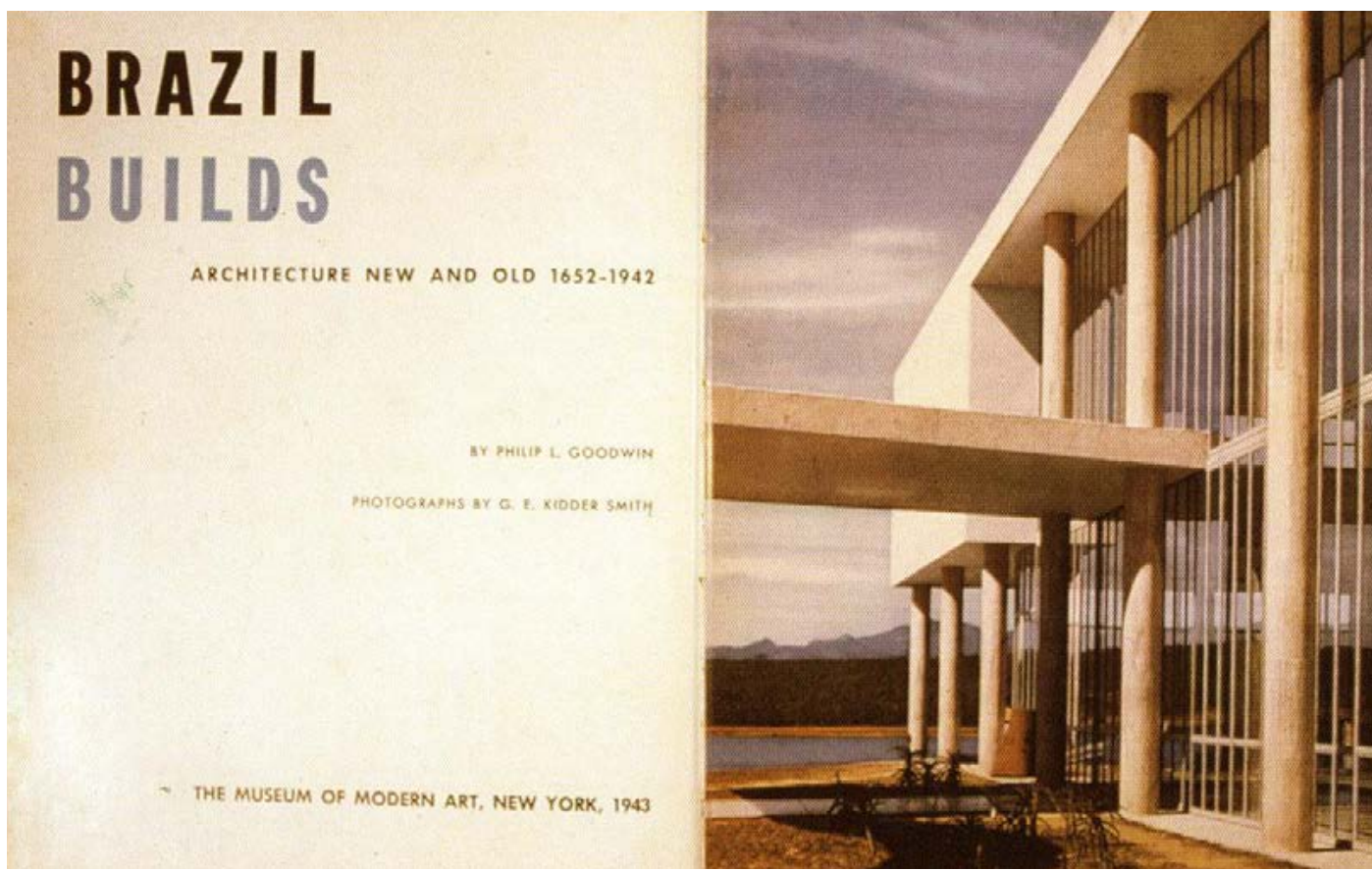

IMG 25.

Brazil Builds. [GOODWIN, 1943: s/n.]

No campo da arquitetura, a política da boa vizinhança financiaria a construção do pavilhão brasileiro na Feira Universal de Nova York, em 1939, a cargo de Lucio Costa e Oscar Niemeyer, ponto de inflexão na recepção e divulgação da linguagem arquitetônica moderna concebida nos trópicos.

Derivaria quatro anos mais tarde, ainda sob o mesmo protocolo, a exposição Brazil Builds que, a partir do MoMA, transitaria, para outras cinquenta localidades, entre 1943 e $1946 .^{22}$ Além disso, a agenda didática da instituição norte-americana apresentaria um festival de música brasileira, paralelo à mostra e abrigaria em seu programa diversos conteúdos dos vizinhos do sul. $^{23}$
Documentação de antecedência: o livro do Museum of Modern Art, Brazil Builds, uma esperança real quase cotidiana, não metafísica, na simplicidade das soluções arquitetônicas, nos "halloos" humanos, coisas desconhecidas para uma geração que chegava de muito longe. Naquele tempo, no imediato pós-guerra, foi como um farol de luz a resplandecer num campo de morte... Era uma coisa maravilhosa. ${ }^{24}$

Se o pavilhão da Feira Universal de Nova York e a exposição Brazil Builds projetaram a imagem cultural do país além-mar, por outro lado, apontariam a necessidade potencial de instituições, em solo brasileiro, capazes de dar corpo a uma agenda

22 lbidem, 165-171.

23 Como a exposição Portinari of Brazil, em 1940; o concurso Industrial Design Competition for

the 21 American Republics, em 1941; o concurso Hemisphere Poster Competition, em 1942 e a exposição The Latin-American Collection of the Museum of Modern Art, em 1943.

24 Lina Bo Bardi. FERRAZ, M. C. org. São Paulo: Instituto Lina Bo e P M Bardi, p. 12, 1993. 


\section{Oque é un museu?}

Um recanto de memórias? Um túmulo para múmias ilustres? Um depósito ou um arquivo de obras humanas que, feitas pelos homens para os homens, já são obsoletas e devem ser administradas com um sentido de piedade? Nada disso. Os museus novos decidiram abrir suas portas, deixar entrar o ar puro, a luz nova. Entre passado e presente não há solução de continuidade. Nada se detem, tudo continua. É necessário entrosar a vida moderna, infelizmente melancólica e distraida por toda espécie de pesadelos, na grande e nobre corrente da arte. Estabelecer o contacto entre vida passada e presente. Nêsse sentido os museus novos, tendo compreendido sua função no mundo contemporâneo, encontraram a coragem de exercê-las, e estão mais adiantados que os mais progressivos organismos educativos estaduais. O Museu de Arte de São Paulo é entre os primeiros do mundo que iniciaram ao redor dum núcleo de obras de arte famosas, êsse trabalho de vivifícacão e rejuvenescimento.

IMG 26.

"O que é um museu?" [Habitat n.9,p. 52.] didática que cumprisse tais propósitos pedagógicos culturais.

Munidos de um acervo de "obras representativas de todos os tempos e continentes", ${ }^{25}$ Lina Bo Bardi e Pietro Maria Bardi chegariam ao Rio de Janeiro, em 1946. ${ }^{26}$ Do encontro com Assis Chateaubriand, resultaria o projeto para o MASP, convergindo propósitos sociais e interesses políticos econômicos, que seria parte da agenda pedagógica da instituição paulista sem, no entanto, excluir os privilégios das classes que dariam viabilidade ao projeto: uma aristocracia rural enraizada e uma burguesia industrial recente, perspectivada sempre em conflito com "novo sentido social $[. .$.$] , que se dirige especificamente$ à massa não informada, nem intelectual, nem preparada, ${ }^{, 27}$ o que acentuava o desafio pedagógico proposto, dependente da liberdade de ação necessária para traduzi-lo em agenda.

Assim, a partir do momento que a sociedade paulista atravessava rumo à industrialização, associada ao acúmulo derivado de sua produção de café, ${ }^{28}$ o MASP seria pensado como "testemunho do grau de civilização de um país", ${ }^{29}$ projetando o Brasil além dos limites de seu "espírito caseiro e provincial", ${ }^{30}$ atribuindo "uma gama de ações muito maior, internacional, uma proposta não apenas adequada para São Paulo, mas para o Brasil, em um palavra, relação com a cultura externa, tentando afirmar o nacional além-fronteiras", ${ }^{31}$ que fosse então capaz de produzir uma imagem cultural crítica, apoiada em uma ação social transformadora.

\footnotetext{
25 "Uma significativa exposição de 'Nós e o Antigo'. Um Studio de arte no alto de um arranha-céu. Que é o Studio d'Arte Palma - organizador da adaptação do 'Museu de Arte' - criador das mostras didáticas - um conjunto escolhido de obras de arte", Diário de São Paulo, 08 de agosto de 1948.

26 Bardi realizaria três exposições na capital: sobre mobiliário, no Copacabana Palace e sobre arte italiana, antiga e moderna, no Ministério da Educação e Saúde. Ver Pietro María Bardi, "El Museo", El Mundo de los Museos. Buenos Aires: CODEX, 1967, p. 23.

27 Lina Bo Bardi, "O Museu de Arte de São Paulo. Função social dos museus ", Habitat n.1, op. cit..:17.

28 Pietro María Bardi en Sodalício com Assis Chateaubriand, op. cit., 49

29 Alencastro, "Rio", Habitat 6 [janeiro a março de 1952]: 92.

30 Pietro María Bardi, História do M.A.S.P., op. cit., 11.

31 Pietro María Bardi, Sodalício com Assis Chateaubriand, op. ci t ., 47.
} 
O que é um Museu? Correntemente, quando se quer designar uma pessoa, uma coisa, uma ideia antiquada, inútil, fora de uso, costuma-se dizer: é uma peça de museu. Querendo indicar com estas palavras que, no quadro da cultura contemporânea, o museu ocupa lugar poeirento e inútil. [...] $\mathrm{O}$ museu moderno tem que ser um museu didático, tem que juntar à conservação a capacidade de transmitir a mensagem que as obras devem ser postas em evidência que diríamos quase da função didática [...]. O complicado problema de um Museu tem que ser hoje enfrentado na base "didática" e "técnica". Não se pode prescindir dessas bases, para não cair em um museu petrificado, isto é, inteiramente inútil. ${ }^{32}$

Operando com um pequeno acervo inicial de cerca de cinquenta obras,,$^{33}$ a pinacoteca do MASP seria rapidamente acrescida de inúmeras obras vindas de doações e aquisições de galerias de todo mundo, em circunstância favorável para aquisição no pós-guerra, construindo a "maior coleção de arte ocidental da América Latina". ${ }^{34}$ A pinacoteca em construção receberia desde peças da Antiguidade às obras modernas, passando por pinturas e esculturas renascentistas, barrocas, românticas e impressionistas, ${ }^{35}$ pautando a "simples ideia" de que "a arte tem uma história única, não obedecendo aos limites de espaço e tempo; importante é a seleção dessa arte e como abordá-la e prepará-la para discussão". ${ }^{36}$

Nesse ideia, no entanto, estava contida uma "unidade que compreende uma diversidade", 37 como "consciência universal", ${ }^{38}$ por meio de uma prática pedagógica que mostrada a arte em sua historicidade, através das contextualização das obras em seu momento histórico, em que "a obra de arte não se localiza segundo um critério cronológico, mas é apresentada quase intencionalmente para produzir um choque que desperta reações de curiosidade e investigação", 39 além de sua equidade, ou seja, a partir da não separação, antevista por Riegl entre artes maiores e menores. ${ }^{40}$

O MASP inauguraria uma agenda ampla, pautada na exposição de artistas como Portinari, Calder, Le Corbusier, Toulouse Lautrec, Van Gogh, além de mostras sobre mobiliário e desenho industrial. ${ }^{41}$ No que se refere à cultura popular, a instituição apresentaria as exposições Arte dos Alienados, Cerâmica do Nordeste, Arte Indígena e Arte Negra, consonante à ideia da arte, reiterada como expressão humana e não como um exercício de privilégio de classe.

Pietro destacaria que o museu mesmo que ligado à esfera da organização política, detinha "uma condição explícita de liberdade absoluta, que garante sua independência, autonomia e objetividade, é reconhecida por essa atividade. Atritos e colisões de origem política devem permanecer fora do domínio da competência da cultura. Então, a colaboração entre todas as forças da cultura humana podem influenciar, por linhas convincentes, na formação democrática de homem moderno". ${ }^{42}$

Do otimismo norte-americano do design e do mobiliário doméstico por uma cultura racional e estimulante, já antevista ainda na Itália nas páginas da Revista $A$, com o intuito de fomentar uma agenda didática que se equiparasse às organizações mais progressistas, ${ }^{43}$ o MoMA seria uma referência válida, junto aos demais "museus vivos

32 Bardi, Lina Bo. "Casas ou Museus". Crônicas de arte, de história, de costume, de cultura da vida 5, Diário de Notícias, 1958. 33 A lista de doadores e contribuintes para a formação do acervo original de M.ASP. Habitat n.1 [outubro-dezembro de 1950 ]: 44. 34 Pietro Maria Bardi. Sodalício com Assis Chateaubriand. São Paulo: Museu de Arte de São Paulo Assis Chateaubriand, $1982,76$. 35 Começando com Picasso e Rembrandt logo viriam: Cézanne, Mantegna, em 1948; Gainsborough e Turner, em

1949; Toulouse Lautrec, em 1950; El Greco e Goya em 1951; Van Gogh em 1952; depois Hieronymus Bosch, Bellini, Bernini, Botticelli, Zurbarán, Chagall, Delacroix, Picasso, Degas, Memling, Tintoretto, Tiziano, Van Dyck, Franz Hals; Manet, Monet, Gauguin, Renoir, Cézanne, Lautrec, Rubens, Goya, Bellini, Matisse, Clouet e Chardin, em 1954.

36 "Uma arte moderna assim", Habitat n.10 [janeiro-março de 1953]: 67

37 Aldo Van Eyck, "Um dom superlativo", em Museu de Arte de São Paulo. Lisboa: Blau, 1997

38 Pietro María Bardi, "Por uma nova cultura do homem", Habitat n.2 [janeiro a março de 1951]: 2.

39 Lina Bo Bardi, "O museu de Arte de São Paulo. Função social dos museus", Habitat n.1, op. cit. : 17.

40 Ver Alois Riegl. Arte Tardoromana. Turim: Giulio Einaudi, 1959.

41 Pietro María Bardi, "An educational experiment at the Museu de Arte Sao Paulo", Museum vol. I, n. 3-4

42 Pietro María Bardi, "Por uma nova cultura do homem", Habitat n.2 [janeiro a março de 1951]: 2.

43 Lina Bo Bardi, "O que é um museu", Habitat n.9 [outubro - dezembro de 1952]: 52. 
dos Estados Unidos", os primeiros a entender a função educacional das novas instituições. ${ }^{44}$ Se a mirada aos museus vivos dos Estados Unidos se constituía como um raciocínio valido para a institucionalização do patrimônio recente, Ethel Leon avalia que "as exposições que o MASP promoveu em seus primeiros anos mostram claramente que a intenção de seu diretor não era apenas a de montar um acervo precioso com obras de diversos períodos, mas também contribuir para uma espécie de atualização do gosto do público". ${ }^{45}$

44 "Os Museus vivos nos Estados Unidos", Habitat 8 [julho-setembro de 1952]: 12.

45 LEON. Ethel. IAC - Instituto de Arte Contemporânea escola de desenho industrial do MASP (1951-

1953) - primeiros estudos. Dissertação de

Mestrado apresentada a FAUUSP, 2006, p.16.

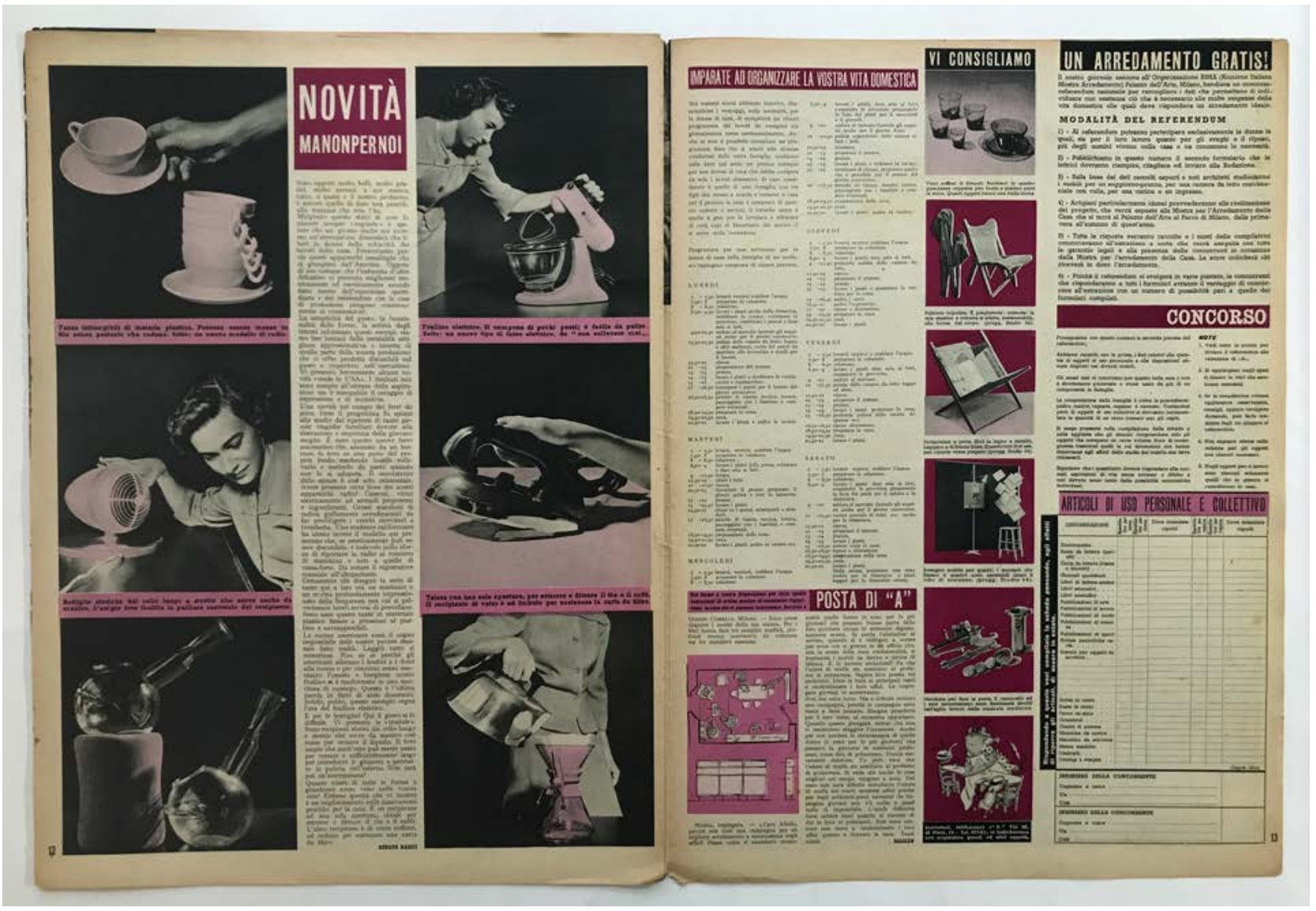

IMG 27.

Revista $A$

- eletrodomésticos.

JULIANA VILLELA JUNQUEIRA

[Revista A, 1946]. 
Se intelectuais realmente responsáveis reconhecerem que uma nova era se abriu e que uma revolução está prestes a chegar, a revolução do cultura, [então] o problema educacional chegaria à frente: e nosso museu - ou contra-museu, como queremos chamá-lo - deve ser considerado.46

O Brasil moderno estaria no horizonte dos desafios impostos em que a falta de bases sócioeducacionais impunha ao crescimento econômico uma forma não coincidente com a ideia de progresso. ${ }^{47}$ No desejo de construir uma nova realidade social no país, "em que poderia se tornar em um museu como o nosso, o interesse pela história da arquitetura e arquitetura viva: as pessoas ficariam perturbadas com os problemas que vão de suas próprias casas, ou mesmo da cadeira em que se sentam, ao planejamento urbano, ao planejamento do país e, porque não?" ${ }_{48}$

Na contramão desse quadro, no final de 1950, surgiria Habitat - revista das artes no Brasil, cujo propósito se daria no escopo de "resolver a questão das artes como um fato educacional". 49 Por "Habitat", Lina e Pietro designariam "uma palavra intimamente ligada à arquitetura, à qual atribuímos um valor e uma interpretação não apenas artística, mas também uma função artisticamente social" ${ }^{50}$ Nele, os valores necessários a uma cultura moderna: "dignidade, conveniência, moralidade da vida e, portanto, espiritualidade e cultura". ${ }^{51}$ Para Pietro, a revista estaria destinada ao "povo iluminado, sereno, educado, que pensa" ${ }^{952}$, defendendo o acesso da arte na formulação do gosto moderno, que estaria no desenho de uma nova sociedade..$^{53}$
A ideia de 'Museu' é ainda das que se acham entrosadas, na mentalidade da maioria das pessoas, com a ideia de mausoléu intelectual, o que se deve entender como fruto particular da organização dos museus instalados na base da conservação e da especialização, em que se fecham as coleções em edifícios arquitetonicamente aparentando formas da antiguidade (clássica ou do Egito), sufocadas sob as cúpulas, as escadarias monumentais, os salões cheios de colunas, tornando-se assim uma embaraçosa superfluidade... ${ }^{54}$

O problema educacional refletiria métodos pedagógicos ineficientes, desatualizados e rotineiros, ${ }^{55}$ que precisariam ser transpostos ao campo artístico, tencionando os limites da construção social que estaria na base no projeto do museu. Somada a inexistência de um programa educacional no campo da arte, havia a estrutura incipiente de setor, entre museus, galerias, colecionadores, publicações e críticos. ${ }^{56}$

O extraordinário conjunto de ensinamentos que a arte do passado e em andamento contém em si mesma [...] deve desempenhar um papel de liderança na educação moral de cada cidade . [...] A unidade das artes significará: participação da arte na sociedade e contribuição para sua futura sistematização. [...] Acredito que chegou a hora de reformar os museus, refazê-los para servir o povo, guiar a formação de seu gosto, colocá-lo à frente do antigo, ou seja, diante das instalações de sua própria vida, para que eles extrair energias vitais, úteis para o futuro. ${ }^{57}$

O Brasil, a partir de um reconhecimento de si mesmo por meio das manifestações

\footnotetext{
46 Pietro María Bardi, "Musées hors des limites", Habitat 4 [julho-setembro de 1951]:50

47 Alencastro, "Cultura não estrangeira", Habitat 10, op. cit. : 92

48 Pietro María Bardi, "Musées hors des limits", Habitat n.4, op. cit .: 50.

49 Prefácio, Habitat 1, op. cit.

50 Ibidem

51 Lina Bo Bardi, " Habitat ", em Lina Bo Bardi , op. cit. p. 64

52 Pietro Maria Bardi, "O antigo e nós", Habitat 12, op. cit. : 57.

$53 \mathrm{Em}$ prol do gosto moderno, as páginas da revista apontavam o colecionismo como forma de "apoiar as obras artísticas da própria terra". In: "Convidar para colecionar", Habitat. n 4, op. cit. : 41

54 Lina Bo Bardi, "O museu de Arte de São Paulo. Função social dos museus", Habitat n.1, op. cit. : 17.

55 Helio Duarte, "Arquitetura e o problema escolar" Habitat 4 op. cit. : 4

56 Ver Alencastro, "Colecionadores", Habitat 4, op. cit.: 95 e Alencastro, "Atenas", Habitat 13, op. cit.: 94. "Qual o futuro das artes no Brasil?", Habitat 7, op. cit.: 26; Alencastro, "Traduções", Habitat 2, op. cit.: 90

57 Pietro María Bardi, "Musées hors des limites", Habitat 4 [julho-setembro de 1951]: 50.
} 
nos campos da cultura e da arte, balizavam o conteúdo da revista, cujo estado da arte seria representado, em primeiro plano, por produções nacionais - mas em diálogo com os acontecimentos estrangeiros considerados relevantes. Caberia à "Habitat, por princípio e por hábito, [publicar] eventos brasileiros. Quando fora de os limites pré-determinados o fazem descobrir, em outros mundos, em outras esferas, tudo o que você encontra do brasileiro; ou, pelo menos, tudo o que poderia ser útil para o Brasil"". ${ }^{58}$

A história das artes em Brasil continua ainda em grande parte inexplorada; no momento, não é uma crônica contemporânea que progride com uma velocidade surpreendente. Assim, acontece que o passado, tão rico em temas de re-evocação, e a atividade efervescente do presente, ainda não possui documentação e informações adequadas à realidade e à sua importância, embora a cada dia aumente o desejo de saber o que isso é feito no país e fora dele em matéria de arte. ${ }^{59}$
Seu conteúdo sintetizava a agenda pedagógica do MASP, entre questões relacionadas às artes plásticas, desenho industrial, paisagismo, moda, teatro, dança, cinema e arquitetura, pautados pela não distinção entre artes maiores e menores, que se mostrava tanto na ação horizontal que dispunha a todas, tanto em seu espaço físico quanto em suas páginas, apresentando ao grande público artistas consagrados e anônimos. Assim, caminharia na direção da formação de um gosto próprio, sensível à realidade histórica do país e suas contingências sócioeconômicas, que refletiam a vida material e espiritual do país.

$O$ antigo seria colocado dentro de suas categorias próprias, em sua historicidade, entendimento que, transposto para a sociedade industrial, apontava para uma tradição a partir da modernidade artística, na autenticidade do moderno que, em seu presente histórico, se validava mais por acumulação do que por ruptura, sendo o passado entendido como fundamento do presente, cuja condição moderna se validava na medida em que culturalmente autêntica.

58 "Arranha-céus e o espirito", Habitat 8, op. cit .: 1 .

59 "Prefácio", Habitat 1, op. cit .: 1.

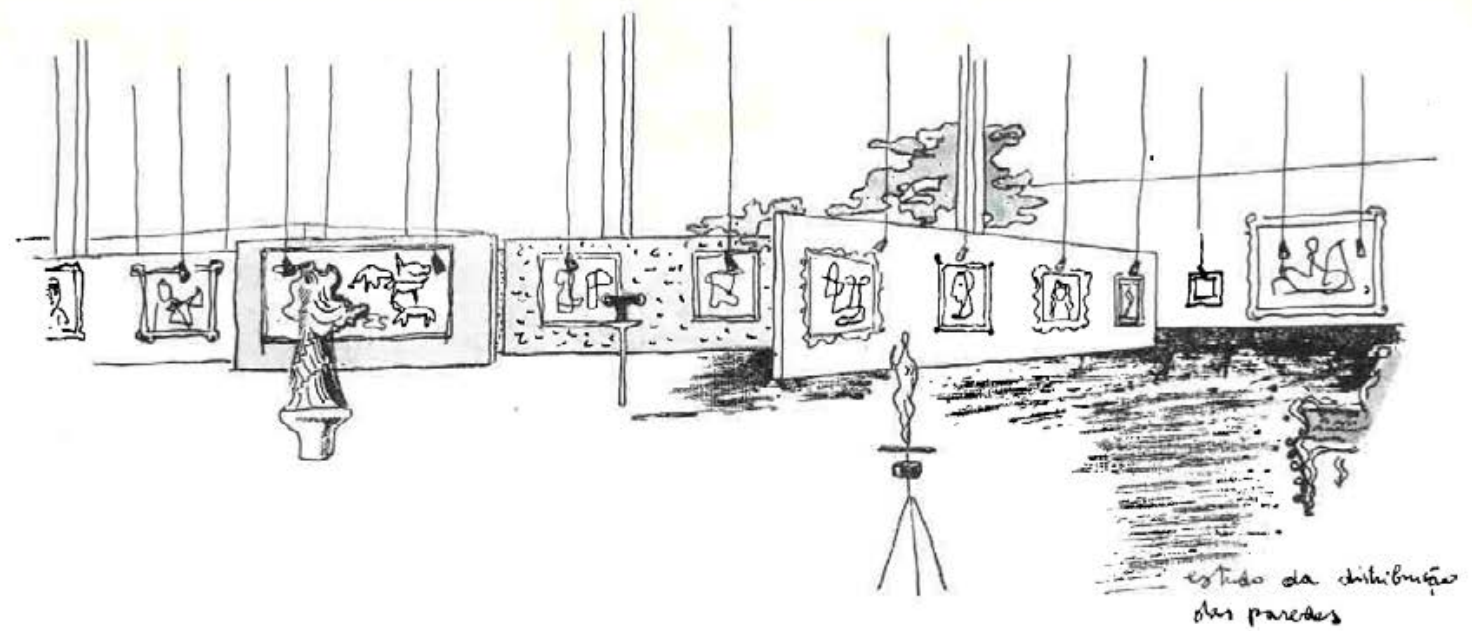

Estudo para as paredes de esposição. 

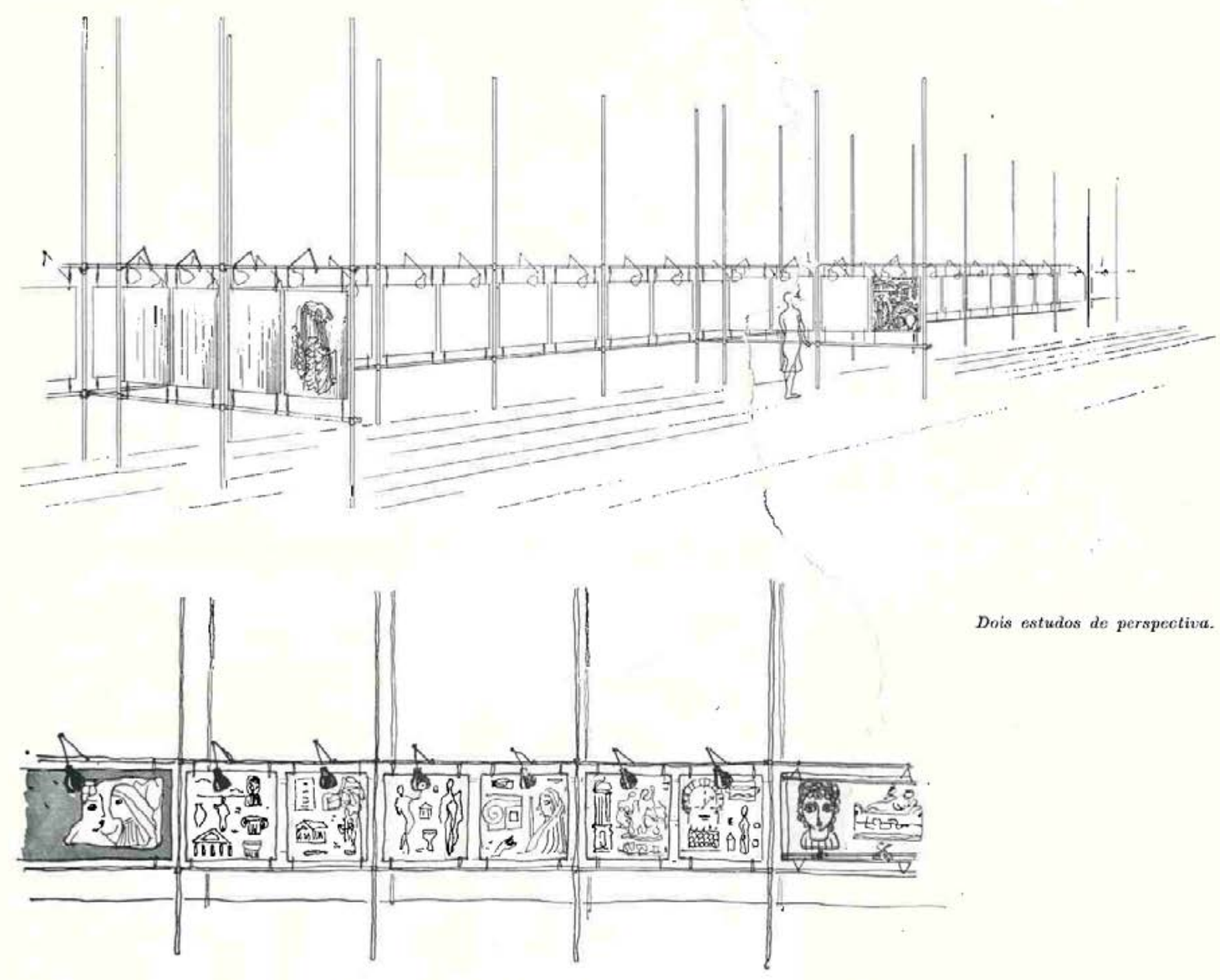

IMG 29.

Exposições Didáticas.

[Habitat n.1, p.35]

Em relação ao projeto expositivo, duas iniciativas fundamentariam o projeto pedagógico da instituição. A primeira, denominada Exposições Didáticas, reproduziria cerca de quinhentas imagens com legendas sobre determinado movimento artístico, substituídas a cada seis meses, expostas em fileiras de "painéis de fácil compreensão", ${ }^{60}$ cuja fixação em barras metálicas independentes dos planos, permitiria o aproveitamento integral do dispositivo de exposição em ambos os lados. ${ }^{61} \mathrm{~A}$ experiência didática estaria marcada por essa atitude em relação ao passado, como componente do presente em sua historicidade, "uma conduta apta a criar no visitante a forma mental adaptada à compreensão da obra de arte [que] não é localizada segundo um critério cronológico mas apresentada quase propositadamente no sentido de produzir um choque que desperte reações de curiosidade e de investigação". ${ }^{62}$

60 Pietro María Bardi, História do MASP , op. cit ., 15

61 Técnica expositiva amplamente utilizado na Itália, nas décadas de 1930 e 1940, por

Edoardo Persico, Franco Albini, Giuseppe Pagano, entre outros.

62 Lina Bo Bardi, "O Museu de Arte de São Paulo. Função social dos museus ", Habitat n.1, op. cit..:17 


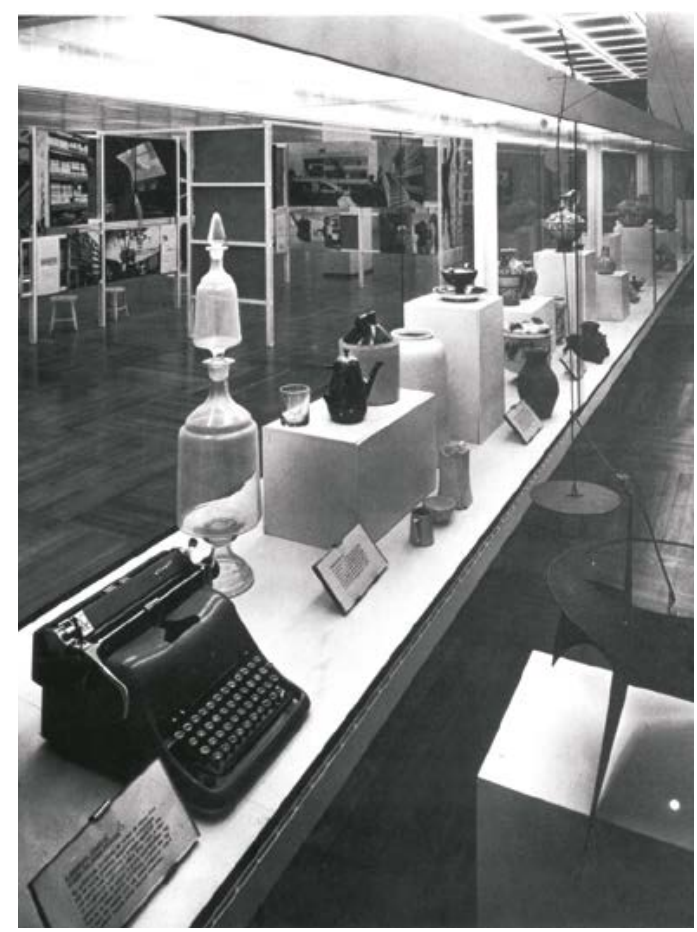

IMG 30.

Vitrine das Formas. [Habitat n.1, p.35]

Em cada painel, há exemplos e ilustrações de um período da história organizado em quatro faixas horizontais: 1. Elementos da história e da vida civil; 2. arquitetura; 3. escultura; 4. tinta. As cópias das obras mais importantes têm um tamanho razoável e quase todas são coloridas. Cada painel contém uma explicação muito simples. A seção também inclui displays de vidro com obras de artes aplicadas pertencentes ao período descrito nas placas. Os grupos de visitantes ou estudantes são acompanhados por um assistente que descreve o que está nas figuras e mostra as imagens na galeria. ${ }^{63}$

A segunda, Vitrines das Formas combinaria itens de naturezas e períodos históricos diversos, provenientes das exposições permanentes e temporárias, como "pedras e tannagras lacadas, cerâmica do século XVI, jóias do século XVIII, Osíris do Egito, Budas do Tibete, uma cópia do Código Napoleão e um copo de Émile Gallé, gravuras de Kandinsky e uma máquina de

63 Relato de Pietro Maria Bardi sobre a primeira exposição didática Panorama da História da Arte, desde suas origens até o presente, em "An educational experiment at the Museu de Arte Sao Paulo", Museum vol. I, n. 3-4, op. cit. escrever", ${ }^{64}$ desvelando critérios de "proporção, racionalidade, inteligência, gosto, arte e historicidade" .65

As páginas da Revista Habitat, editada por Lina nos primeiros números no início da década de $1950,{ }^{66}$ sintetizam o projeto cultural em que o conceito de modernidade está amparado numa visão que conecta homem e cultura, agindo sobre a fratura entre teoria e prática, pontuando a noção do tempo e sua relação com a produção.

Do passado pretendemos haurir germes da vida, não por mera exumação histórica, mas sim porque nós nos consideramos resultantes de tempos idos; dedicaremos pois ensaios à história da arte brasileira, a fim de fundir os tempos em uma só época, sem a baliza das classificações, dividindo o antigo do assim chamado moderno. ${ }^{67}$

Para além do presente, o tempo é visto de forma dilatada na acumulação dos estágios anteriores ao período em questão. Essa concepção do tempo em um continum estende a ideia de presente que necessariamente expõe suas camadas anteriores. "Entre passado e presente não há solução de continuidade. Nada se detém, tudo continua. É necessário entrosar a vida moderna [...]. Estabelecer o contacto entre vida passada e presente. ${ }^{968}$ Bardi, completaria: "Estudar nosso passado significa conhecer a nós mesmos". ${ }^{69}$

Ao desenvolvimento da produção crítica no campo da arte estaria contida a noção de progresso, entendendo o atraso do país na esfera artística, à inexistência de um setor especializado. ${ }^{70}$ Sob o pseudônimo de "Alencastro", "11 Lina utilizaria a ironia como forma de combate ao mau gosto e à alienação de uma burguesia recente que se colocava como entrave para a formação de uma cultura autóctone. ${ }^{72}$

64 Pietro María Bardi, "El Museo", El Mundo de los Museos, op. cit., 24.

65 "Vitrinas das Formas", Habitat 1, op. cit. : 35

66 Lina seria responsável pelos números 1 a 9 da revista Habitat; os números 10 ao 13 seriam dirigidos por Flávio Motta e, finalmente, os números 14 e 15, estariam sob a responsabilidade conjunta de Lina e Pietro.

67 "Prefácio", Habitat 1.

68 "O que é um museu?", Habitat n.9, p.52.

69 Pietro Maria Bardi, "O antigo e nós", Habitat n.12, op. cit . 70 Alencastro, "Atenas", Habitat 13, op. cit. : 94

71 Renato. Interlocuções com a arquitetura moderna italiana na constituição da arquitetura moderna em São Paulo. p.68.

72 Ver: Alencastro, "Dona Yolanda", Habitat 12, op. cit.: 91, "Mais uma amadora", Habitat 7, op. cit.: 40., Fiorani, Habitat 10, p.93 . 


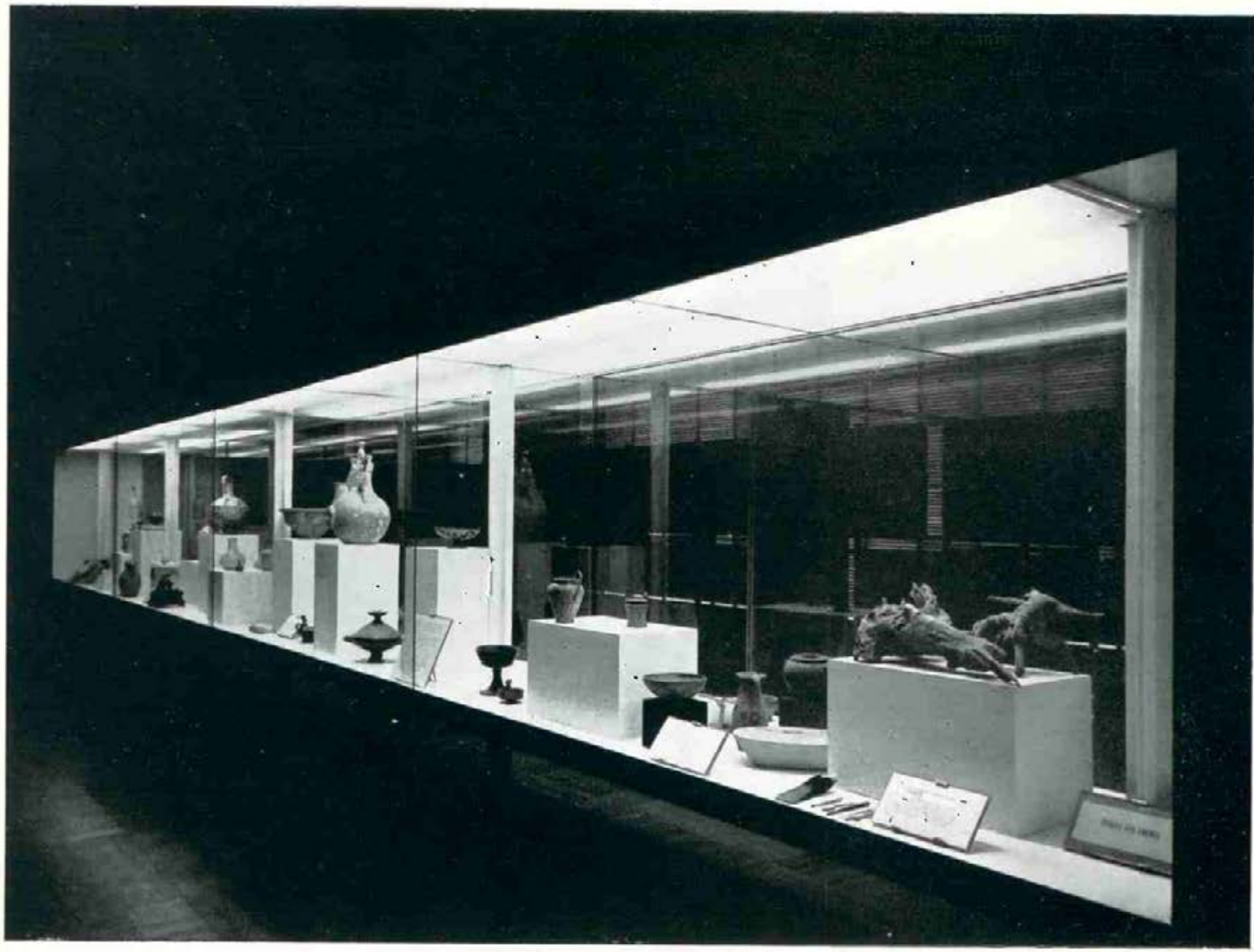

A vitrina das formas; uma grande vitrina com paredes de cristal, divide a parte de exposicao permanente da parte de exposica periódiç. A haz provém do próprio této da vitrina, através de vidros que a difundem.

\section{Vitinnas das formas}

Estas exposiçōes periodicas tem um sentido museológico diferente: não pretendem ser uma apresentação de objétos "antigos", mas uma reuniāo de um conjunto orgánico de formas variáveis, criadas por civilizaçōes diferentes ou originarias simplesmente de circunstancias casuais, mostrando a variabilidade $d a$ fantasia humana na criaçâo e na modificaçâo dos materiais dentro de um impulso renovador incessante.

A maioria das pessóas costuma encarar a forma com certa indoléncia visual, isto e, com falta de discriminação ou espirito de comparacado, quase sempre sem nenhuma preocupacto eritica, adquirindo um copo ou um aparelho de ródic, uma miquina de tura ou um vaso, sem conciência da importancia e da responsabilidade que a entrad de Verdade to que na maioria das veres a propria arquitetura da casa obedece a mesma confusâo de valores e de gôsto. Estu exposiça visa portanto despertar a atencio sobre: propono, racionalidade, inteligencia, sosto. arte historicidade de toda $e$ qualquer Jorma

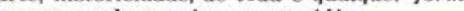
pom a qual se entre em contáto.

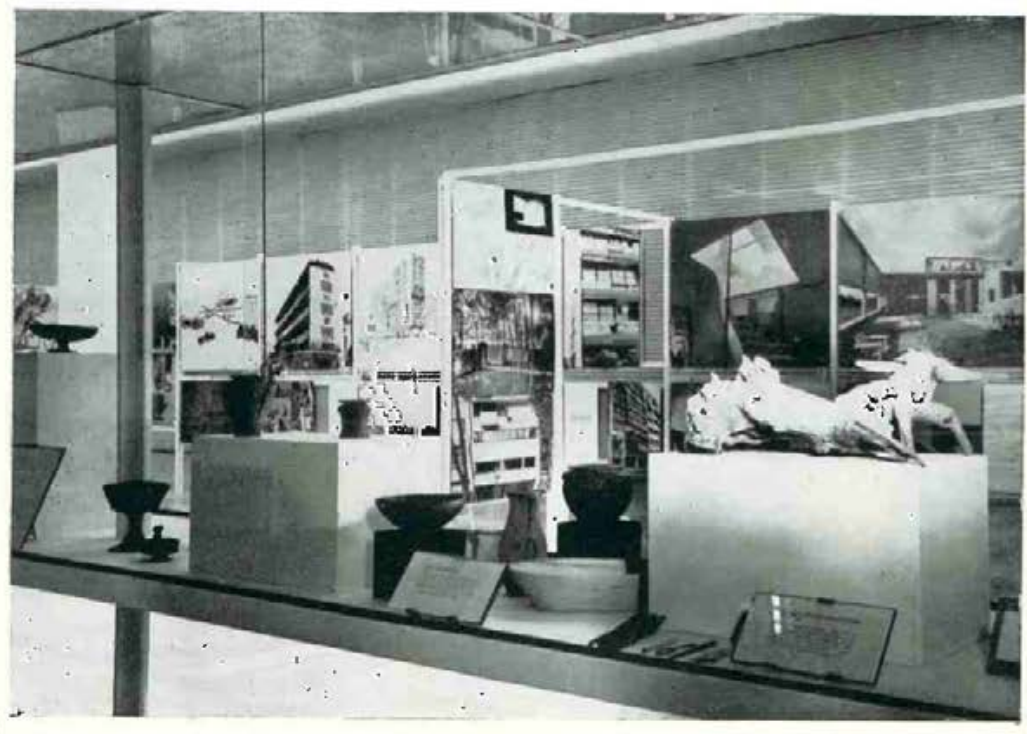




\section{Habitat}

A nossa revista, como é sabido, é uma revista de divulgação: a finalidade é a de levar ao conhecimento do maior número de pessoas cultas o maior número de problemas das artes brasileiras. Muitas vêzes nossas descobertas têm um sabor arqueológico, não por estarmos cavando debaixo da terra, mas porque estamos cavando no desconhecido, no mais profundo dos desconhecidos assuntos artisticos brasileiros. Publicamos, continuadamente, inéditos não sòmente do Brasil mas também inéditos brasileiros que estão nos museus estrangeiros e que são, naturalmente, desconhecidos por nossos estudiosos. Muitas vêzes acontece que nós, jornalistas, fazemos alguns erros. Atribuimos, por exemplo, uma cerâmica carajá a outra tribu que reside a pouca distância, ou vice-versa. Então, o exército dos especialistas atira-se contra nós, mas não com uma carta ou retificação qualquer, mas se atira contra nós nas conversaçóes, aproveitando-se de tôdas as oportunidades e dizendo que somos diletantes etc.

Declaramos, por isso, que diletantismo por diletantismo, preferimos o nosso, que deu à arte brasileira uma revista, sua arena para as discussōes. Habitat, como disse há algum tempo o professor Lourival Gomes Machado, rompeu a praxe das revistas brasileiras de cultura que morrem no sexto número ou antes disso. Assim, mais uma vez, lançamos o nosso brado fatídico: "Diletantes de todo o mundo, unamo-nos".

IMG 32.

"Mais uma amadora". [Habitat n.12, p.96]
Mais um primitivo

Mais um pintor primitivo? Mais um, e nảo será o último. Enquanto a pintura profissional náo se decidir por um camınho - um caminho qualquer - e comecar a se tornar consistente, èstes pintores domingueiros serão a afirmação de que a divina arte que Antonio Tari colocaya no ápice de sua Imaginaria piramide das artes, não está ainda esgotada.

A pintura, uma arte de silenciosos, uma arte que prescinde de bate-papos e tapeaçōes, é a arte que obriga o seu escravo a pensar sómente nela (muitos, errôneamente, acreditam que os pintores domingueiros pensam na arte apenas entre o sábado e a segunda feira. Náo é verdade: os domingueiros pensam na arte da segunda ao sábado, acumulando sensaçóes, vontades, desejos, idéias, invençōes, tudo o que podem, e depois, no dia festivo, agarram a palheta e póem fora, entāo, o seu parto. E é aqui, exatamente,

\section{Mais uma amadora}

Os nossos leitores, que já compreenderam qual o interèsse que "Habitat" manifesta pelas aventuras da pintura, terāo notaem nossas colunas para esforcados diletantes, que, com a sua ingenuidade, com o candor próprio de quem pela primeira vez se compromete com a arte, ou com algo que the afete o sentimento, aos esforçados diletantes que pintam um quadro, modelam um pedaço de madeira, escrevem uma poesia: aos jovens que por qualquer manelra procuram ativar um comercio com o espirito e superar, asSim, um pouco, os comercios muito materiais da vida. O diletante brasileiro, que pode ser o antigo guarda noturno de um hotel em Sáo José do Rio Preto, o excelente negro da Bahia, um dêsses pretos que em nosso namero anterior a as Valladares: ou entào, a pessoa que em certo domingo resolveu exercer qualquer: concreta manifestacão da arte. Fsco as sim como qualquer amador nacional, encontrará sempre por parte desta revista a mais fervorosa simpatia.

E, entáo "Habitat" uma revista dedicada aos diletantes? Sim. Somos uma revista dedicada aos dilletantes. A palavra diletante, naturalmente, nos a entendemos como a interpretava Lessing, há dois séculos. Quem o desejar, abre uma enciclopédia, informe-se de quem fol Lessing, adivinhe em que livro se refere o grande critico as diletantes, e se conhece o alemâo, leia o interessante trecho. Diletante, para nos, é todo apalxonado por uma

IMG 33.

"Mais uma amadora". [Habitat n.7, p.40] 

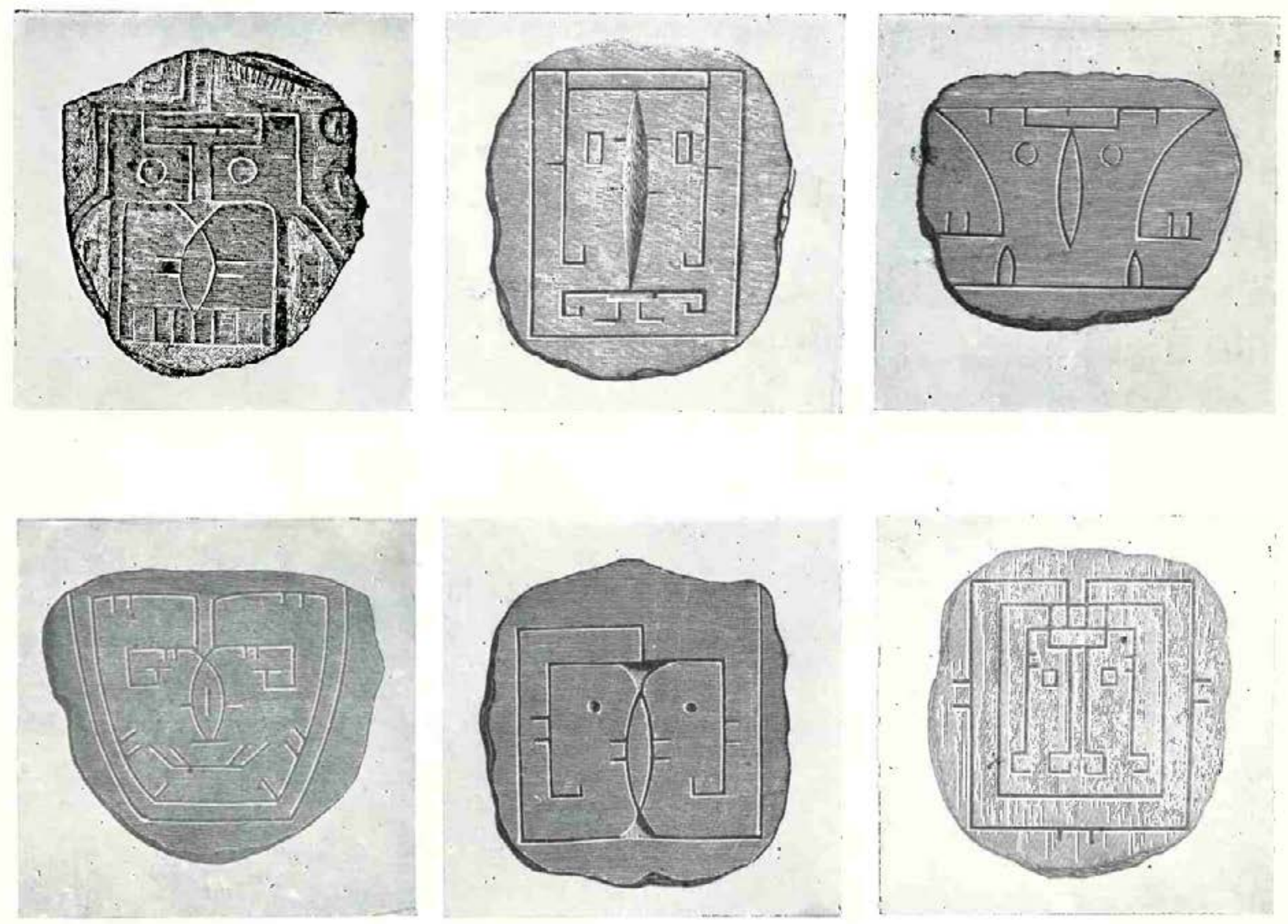

\section{0 índio desenhista}

Quando o indio desenha, èle precede por sensaçōes, por sinteses, por idealizaçōes. Ele nunca aprendeu a dizer a verdade no sentido de exatidão, do cópia, de repetição: sua verdade é simbolica, procede e se resume em sinais fixos, mas variaveis em sua composiçao para oferecer um misto de lenda $e$ de estados d'alma. Eis uma série de retratos geométricos, ricos em linhas infinitas $e$ mis. teriosas, capazes de guiar nosso pensamento nas mais profundas meditaçes. ote jogo 作 pacidade psicologica e absoluta, livre de toda a crosta exterior e superflua. Um re finadissimo pintor contemporâneo nầo iria mais longe. 


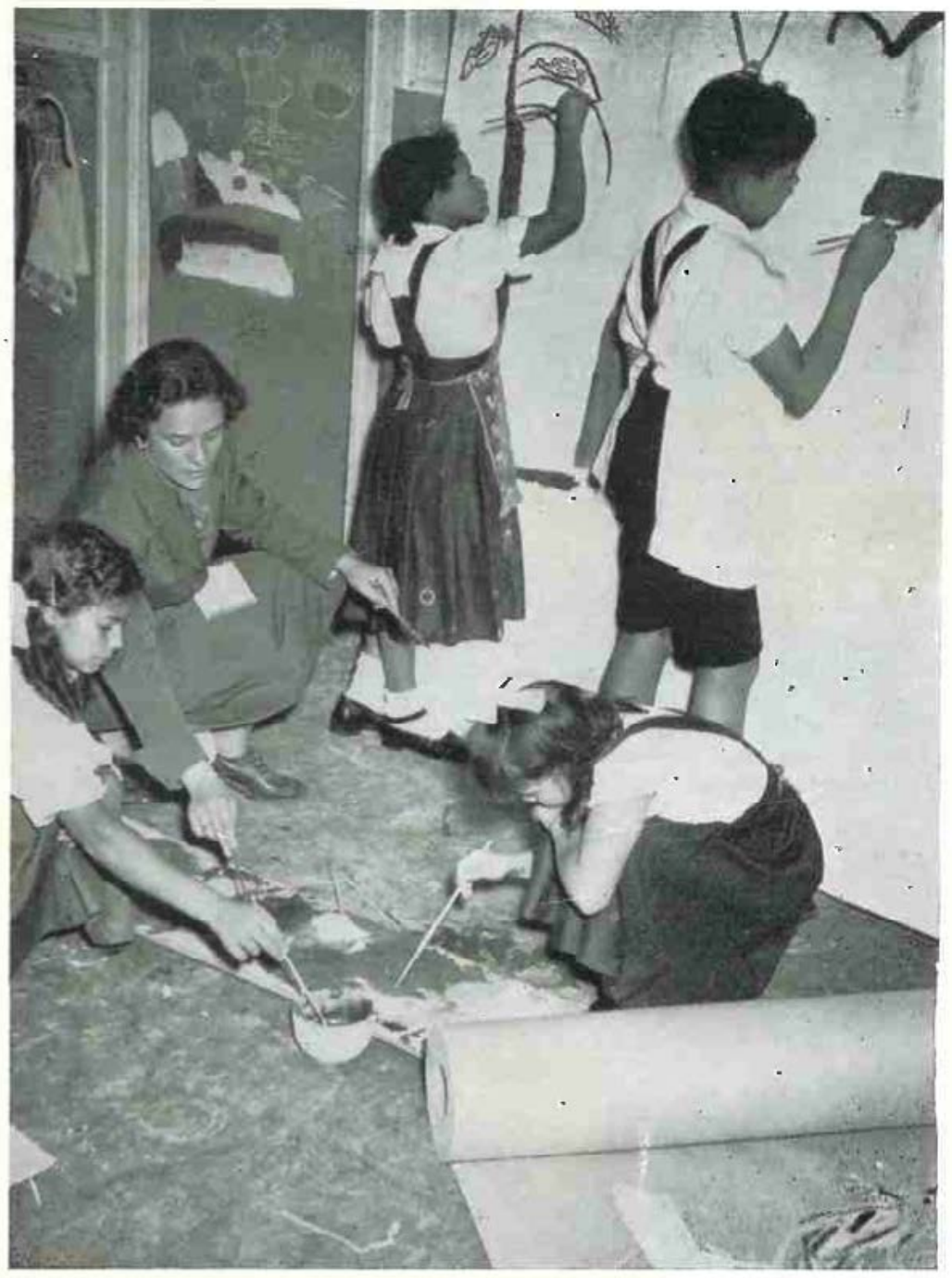

IMG 35.

Clube Infantil de Arte.

[Habitat, n.1, p.93]

A criança do Club Infantil de Arte está preparando as decoraçoes do baile do Arrabal. de, no Club dos Artistas de São Paulo. 


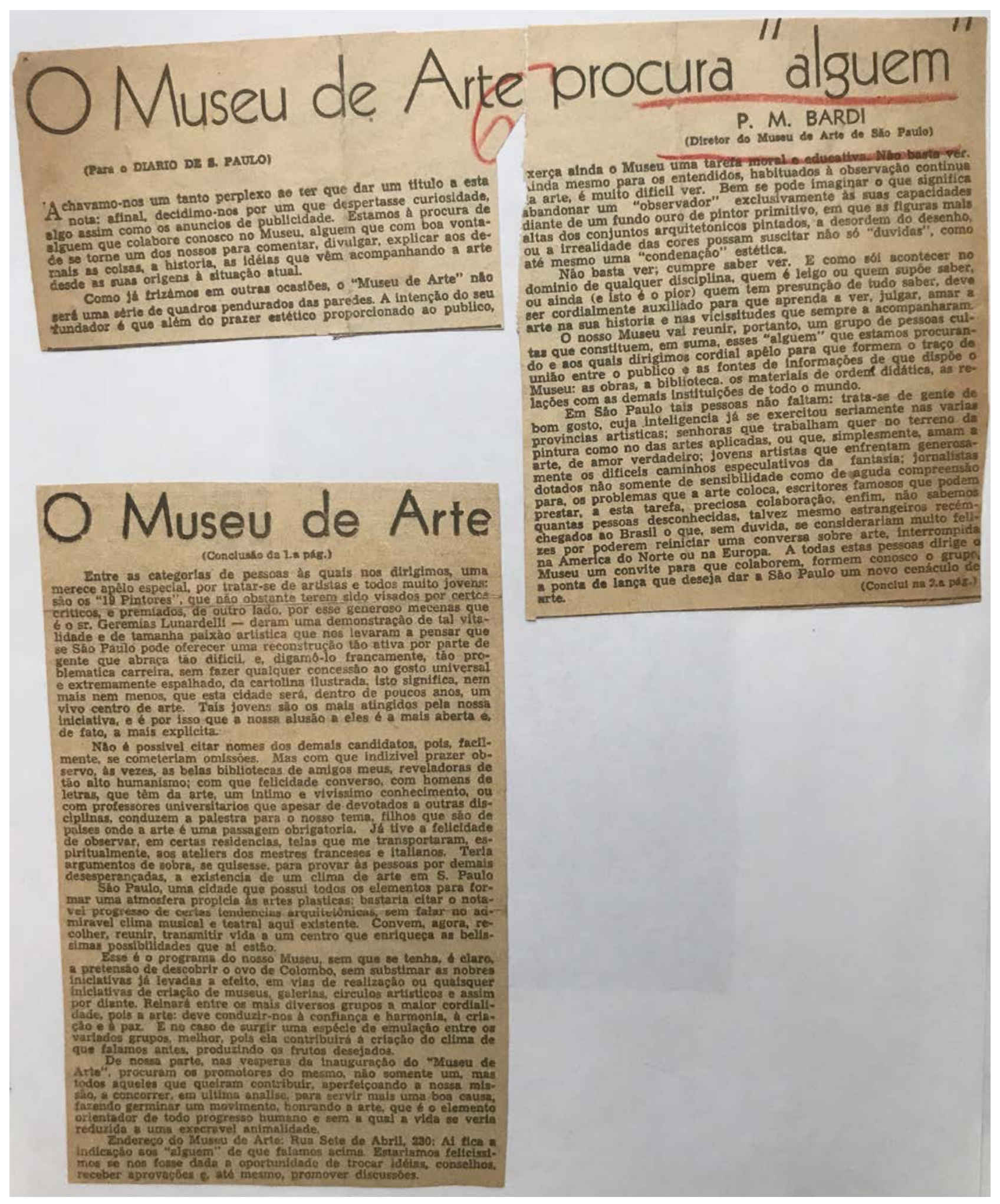

IMG 36. 


\title{
A nossa revista, que nada tem de etnográfica
}

\begin{abstract}
mantem-se firme na sua opinião, ou melhor, na sua fé que é a seguinte: o produto popular genuíno [dizem os cientistas: 'ergológico'] é o germe que contem na sua variedade e espontaneidade a semente de toda a civilização futura, os aspectos de um complexo nacional em elaboração. ${ }^{73}$
\end{abstract}

Nas páginas de Habitat, Lina direcionaria o conceito de civilização para a "vida dos homens o tempo todo", ${ }^{74}$ reunindo "exemplos absolutos de civilização", ${ }^{5}$ constituídos por uma ética consonante ao mundo natural, desde objetos de uso comum pelas comunidades indígenas e outras práticas no interior do país, como cerâmicas Marajoara, ${ }^{76}$ flores de papel machê, Ex-votos das áreas rurais, ${ }^{7}$ produzidos por anônimos, "amplamente não publicados" ${ }^{78}{ }^{78}$

[O conceito verdadeiro do Brasil trabalhador, país de cimento, espaços e riquezas, sua atividade generosa - esse conceito, dizia, deveria ser baseado inicialmente nas camadas sociais do interior, ao longo de rios fabulosos, nos cafezais, nas fazendas de algodão, e nos seringais, nas pontes e oficinas. O milagre de uma sociedade que fala uma só língua há séculos, que se criou

73 "Nossos instrumentos musicais", Habitat n.8, op.cit.: 42.

74 Lina Bo Bardi, "Civilização do Nordeste". Tempos de Grossura: o design no impasse, op.cit, p.35.

75 "Artezanato e Indústria", Habitat n.9, op. cit, p.86.

76 "Cerâmica do Noroeste", Habitat n.2, op. cit.: 72.

77 Alceu Maynard Araújo, "Ex-votos e

promessas", Habitat n.5, op.cit:42.

78 "Prefácio", Habitat n.1, op. cit: Xx. 
numa amalgama de elementos históricos provindos de continentes tão diversos - o Brasil deve ser compreendido através de imagens reais e não através dos falsos instantâneos das boites]. ${ }^{79}$

A natureza ética fundamenta a linguagem "primitiva", por meio de uma necessidade vital, material ou espiritual, cuja engenhosidade genuína deriva de uma ação própria aos meios disponíveis: materiais e resíduos, constituem a matéria-prima a ser trabalhada, de acordo com as necessidades impostas pelo cotidiano.

Essa engenhosidade identificada na ética primitiva cujo tempo transversal atravessa obras de períodos distintos, contemporâneos inclusive, ${ }^{80}$ uma vez que sociedade "é o conjunto dos cidadãos, e compreende todos as classes sem distinções. [...] significa todos os cidadãos, de Einstein ao fazendeiro do Arizona, de Cocteau ao carteiro de Albi, de Mac Arthur a um soldado raso coreano". ${ }^{81}$

De Assis Chateaubriand, respondendo à uma sugestão de Lina que de antemão viu "no aborígene a matéria prima de novas inspirações artísticas, a contribuição valiosa à causa da cultura", ficaria um artigo sobre a "extraordinária influência do elemento nativo, no desenvolvimento da colonização" no povoamento do planalto, em seus usos e costumes.

Numa fase histórica de deslassamento moral, essa solidariedade é comovente, e inspira estudos que façam, de novo, vir a ser o índio, o elemento capaz de fornecer recursos humanos para o povoamento deste solo. Deveríamos insistir em ir buscar na selva, sem trabuco nem propósitos de escravização, o elemento que foi uma das peças da carpintaria humana nacional ${ }^{82}$ [Assis Chateaubriand]

79 Lina Bo Bardi. "Amazônas: o povo arquiteto", Habitat n.1, op. cit:68

$80 \mathrm{O}$ conceito abarca desde Giandomenico de Marchis à Maria Bonomi, passando por Cassio M'Boy e Agostinho de Freitas. Ver "O escultor de Marchis", Habitat n.10, op. cit.: 74-75; "Mais um amadora", Habitat. 7, op. cit .: 40-41; "Mais um pintor primitivo", Habitat 2, op. cit: e Mais um primitivo", Habitat 7, op. cit, respectivamente.

81 Lina Bo Bardi. "Amazônas: o povo arquiteto", Habitat n.1, op. cit:68.

82 Assis Chateaubriand, "O índio e o homem do planalto", Habitat, n.14:2

\section{Gravatas}

Um dia, um cavalheiro val comprar uma gravata: "Como a deseja?" - pede o vendedor. "Nẩo sei, mostre-me algumas". Comeca aí a pôr-se em movimento todo o seu aparato estético, o processo de elaboraçäo se forma, e em pouco a escôlha recai sôbre uma bonita gravata importada dos Estados Unidos. É por isso que no Brasil também se começa a ver o espetáculo da morte da seriedade e compostura nos trajes masculinos, mudanca esta iniciada pelos norte-americanos, há alguns anos. $\dot{E}$ comum ver-se um senhor de grandes responsabilidades, levando, pintadas sôbre a camisa uma rã, duas bailarinas, ou uma cascavel, um relógio, um automóvel, etc.

O homem, em matéria de futilidade, está levando a melhor sôbre a mulher; e êste é um problema grave. O homem norte-americano está modificando seu trajar, e começa pela gravata. Defendamo-nos.

IMG 37.

"Gravatas" [Habitat n.2, p.95] 
com os tamôios, os aimorés e os capichabas: "isto aqui é somente nosso".

\section{Fantasias musicais}

- Carnaval é a mina de ouro de nossos compositores populares. Ao se aproximar o fim do ano, todos os anos, a turma pega a caixa de fósforos, zabumba um ritmo de samba ou de marcha, inventa uma letra qualquer e assobia uma melodia, que um cavalheiro anônimo, nas casas editoras, transformará em notas escritas na pauta. E, aí, é só esperar a chuva dos direitos autorais a cair, como Júpiter no regaço de Dánae, no bôlso de cada qual. Tudo isso gera movimento e muita animação. Chega gente de fora para apreciar o espetáculo. As Autoridades distribuem prêmios. A Atlântida faz logo algum ignominioso filme musical.

O diabo é que, no fim, quando a famosa marcha ou o popularíssimo samba saem à rua, a gente se surpreende, em demasiados casos, topando com algum velho conhecido: é "O sole mio" para cá, "La vie en rose" para lá, músicas italianas, francesas, mexicanas, cubanas, norte-americanas (até Puccini, Verdi e Tschaikowski já foram postos a saque!) tôdas metidas em fantasias baratas para fazerem número no caldeirão carnavalesco e tôdas, mais ou menos, encabuladíssimas de não disporem sequer de máscaras para um modesto disfarce. O fenômeno vem se acentuando de modo alarmante nos últimos anos. Dir-se-ia que, à míngua de inspiração, nossos sambistas optaram pela erudição, se tornaram ratos de biblioteca, fazem questão de exibir cultura. E acontece que suas pretensôes, de que a música transponha as fronteiras e vá deliciar o resto do mundo, encontram lá fora caras amarradas, quando nẵo suscitam a gritaria das vitimas: "Pega! Pega! Fui roubacio de quatro, de cinco, de seis compassos! Chamem a polícia!"

Nossas sociedades de compositores bem que poderiam tomar alguma providência a respeito. Por exemplo: que tal se uma boa parte dos direitos produzidos pilhando-se o alheio, se destinar a indenizar os lesados? Talvez assim os músicos de Carnaval co-

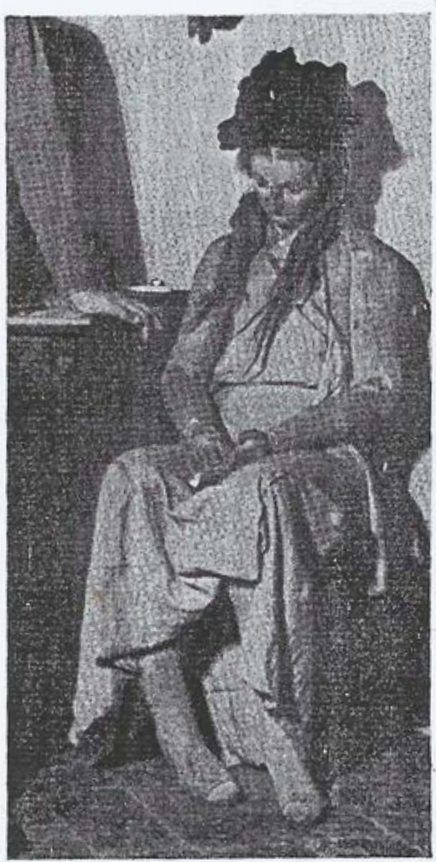

Manequim de pintor em repouso, que está meditando quanto tempo o seu dono perde, com a paleta e as côres.
IMG 38

"Fantasias Musicais" [Habitat n.2, p.95]
Nessas peças orquestradas como valores válidos da cultura popular, estaria uma consciência nacional conveniente para a consolidação de um projeto pedagógico que fomentasse a crítica e instruísse o gosto sob ângulos diversos dos convencionais, sob um prisma da modernidade como síntese de seu lugar, do homem e dos meios disponíveis para a sua produção material e espiritual.

Consciente de que o ser estrangeiro fazia parte da formação do povo brasileiro haveria uma "contradição íntima" entre o solo tropical e civilização, conferindo "a toda a criação do pensamento e da arte latino-americanos, esse conjunto de seduções e falhas que a distingue de todas as outras", ${ }^{83}$ sedimentando uma "afirmação gradual, mas orgânica, interna, etnológica mesmo os fatores mais autênticos que compõem a estrutura [nacional], que são a anatomia do homem brasileiro". ${ }^{84}$

83 "A Itália e o cinema brasileiro", Habitat 7, op. cit. : 90-91

84 "Por uma enciclopédia brasileira", Habitat, n. 9, op. cit.:2. 
A ética do elemento primitivo está na sobreposição do uso em relação à troca, longe, portanto, dos excessos inerentes ao sistema de produção capitalista, exponenciados com o advento da sociedade de massas. $E$ por ser um conceito ligado ao mundo da produção e, portanto, político - desvela uma outra produção possível no horizonte de um sistema igualmente diverso. Entre as manifestações etnográficas do passado colonial e às formalizações de matriz moderna, estaria a mirada do Masp, coincidindo "as formas modernas às formas primordiais das civilizações primitivas".

Ainda que muitas vezes se referisse à uma precariedade que está no bojo da necessidade, a expressão "primitiva" corresponderia à inventividade humana traduzida em uma linguagem que, através dos tempos, tendeu à simplificação de procedimentos relacionados ao fazer tendo o uso, e não a troca, como mote produtivo. Não sendo uma mercadoria, sua razão era despojada do conceito de "belo" (o que mais tarde se traduziria, em Lina, como "o direito ao feio"). E na direção do exercício de sobrevivência de uma civilização que responde eticamente ao mundo cotidiano trilharia a "Civilização do Nordeste" ${ }^{85}$ contra os excessos de um sistema perverso e a favor da resistência das massas rurais por um sistema que as entendam como sujeitos de um processo de autenticidade cultural, associado aos valores da cultura popular por meio da técnica. ${ }^{86}$

Em "A arte popular nunca é Kitsch", Lina contrapõe a natureza que distancia o Kitsch da Arte Popular: a primeira, longe "do povo, é da burguesia e é irreversível". Já a segunda, "mesmo em casos extremos, ela é perfeitamente reversível". A irreversibilidade vinha, ainda, do "verdadeiro sentido do Kitsch [que] é o medo, medo da morte. [...] a hipotética morte de uma Nação", associada aos regimes totalitários e à burguesia que temia enfrentar "o dilúvio das pequenas ternuras familiares $[\ldots]$ a hipocrisia das $[\ldots]$ cortinas bordadas e dos enfeites [...]" ${ }^{87}$

85 Lina Bo Bardi, "Civilização do Nordeste", em Tempos de Grossura: o design no impasse, op. cit., 35-37.

86 Id. "Cinco anos entre os 'brancos'", Mirante das Artes, Etc. 6, op. cit.

87 Id. "A arte popular nunca é kitsch", em Tempos de Grossura: o design no impasse, op. cit., 31. 


\section{Zonti}

"O Brasil terá um cinema que passará a interessar não só aos circuitos do país, mas às telas de todo o mundo, quando for essencialmente brasileiro. O cinema dêste país só terá características essencialmente brasileiras, quando principiar a filmar as humanas e interessantíssimas histórias do povo do Brasil." Assim disse, justamente, o verdadeiro cineasto italiano, Aldo Zonti.

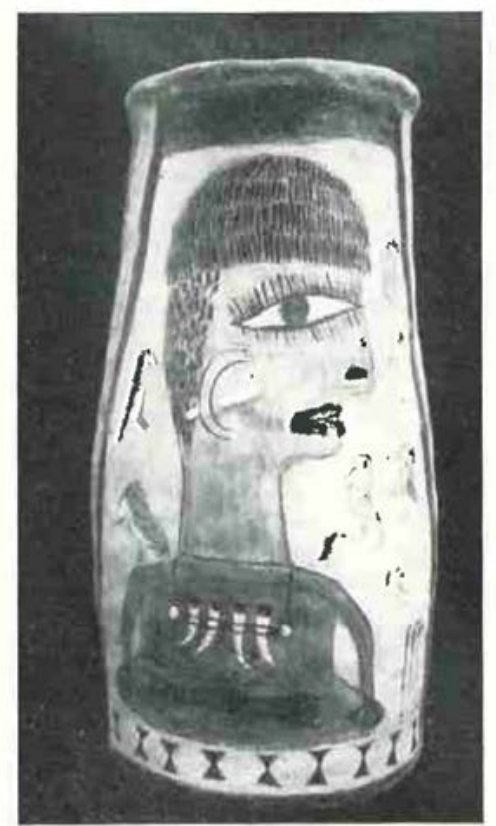

Muito sucesso conseguiu o $\mathrm{Sr}$. Tatin, ceramista francês, na Galeria Domus
Após o fascismo, Lina encontraria, a partir do movimento de reconstrução italiana, uma cultura popular desintegrada. Já o universo popular antevisto a partir de sua imersão nos caminhos do Nordeste, trariam, enfim, "as condições ideais para se construir um país moderno". ${ }^{88}$

Na linha tênue que separa o espírito reacionário do revolucionário no enfrentamento da cultura como fundamento da nação, Lina lançaria mão da diferença aprendida com Gramsci entre nacional e nacionalista cujo compromisso, no primeiro, seria uma afirmação coletiva e, portanto, universal e, no segundo, uma afirmação individual que se sobrepunha às necessidades da maioria. Assim, os nacionais, citando Goethe e Stendhal, Alemanha e na França, respectivamente, exprimiam os "valores reais de um país, enquanto os nacionalistas são atitudes políticas que visam certas particularidades de um país por todos os meios, às vezes até com o uso da violência". ${ }^{89}$

Em função de sua matriz antropológica e adesão racional do momento presente, fato que concederia o estatuto moderno às práticas relacionadas ao universo propositivo da arte popular, Lina vislumbrava um caminho possível para um progresso nacional e independente em suas proposições articuladas no universo da cultura, no "balanço "visto do outro lado" [...] o Aleijadinho e a cultura brasileira antes da missão francesa [...] o nordestino do couro e das latas vazias [...] o negro e o índio". ${ }^{90}$ Nessa matriz popular, cuja ideia-força é a cultura do povo, se mostra, então, "um país de enormes possibilidades". ${ }^{91}$

Habitat seria uma plataforma para publicações de construções anônimas em áreas rurais, fruto das necessidades "das funções da vida [e] chega com segurança às suas finalidades [...] que são: economia, propriedade dos materiais, exato emprego das funções, conhecimento dos resultados práticos". ${ }^{22}$ Ainda na Itália, em 1943, Lina escreveria para a revista Domus um artigo

88 Marcelo Ferraz ,"Salsinha de poucos pratos", A Tarde Cultural, 23 de out. de 1993: 3

89 Lina Bo Bardi, "Discurso sobre a significação da palavra artesanato", em Tempos de Grossura: o design no impasse, op. cit., 17.

90 Id. "Um balanço dezesseis anos depois", op. cit., p. 12.

91 Id. "Por que o Nordeste?", op. cit. 20.

92 "O povo é arquiteto", Habitat n.10, op.cit, 32.
"Zonti"

[Habitat n.4, p. 96] 
pontuando a ética primitiva contida nas construções rurais italianas. ${ }^{93}$

L'indagine realística del mondo moderno, distruttrice di ogni superficialità, di ogni preconcetto, di ogni decorativismo. ha riportato l'architettura al rapporto SUOLO CLIMA AMBIENTE VITA, rapporto che, con meraviglioso primitivismo vediamo scatururire dalla più spontanea delle forme d'architettura: I'architettura rurale. ${ }^{94}$

Da cultura primitiva em seu universo intuitivo e cosmogônico à sua assimilação no horizonte do desenho industrial, em equivalência estaria o adjetivo popular para a produção da arquitetura no país, a partir de sua ética incumbida de uma razão social. No influxo colonial, a arquitetura brasileira revelaria sua autonomia sob a perspectiva do trabalho humano amparado pela consciência técnica vinda da necessidade.

A arquitetura contemporânea brasileira não provém da arquitetura dos jesuítas, mas do 'pau a pique' do homem solitário, que trabalhosamente cortara os galhos na floresta, provem da casa do 'seringueiro', com seu soalho de troncos e o telhado de capim, é aludida, também ressonante, mas possue em sua resolução furiosa de fazer, uma soberbia e uma poesia $[. .$.$] do homem do sertão, que não$ conhece as grandes cidades da civilização e os museus, que não possue a herança de milênios, mas suas realizações - cuja concretização foi somente possível por esta sua soberbia esquiva - fazem deter o homem que vem de países de cultura antiga.95 [Lina Bo Bardi, "Bela Criança", Habitat n. 2, op. cit .: 3]

Estamparia as páginas do primeiro número de Habitat, a moral severa de Vilanova Artigas, na casa que "quebra todos os espelhos do salão burguês. [...] contra o clima, vento e chuva, mas não [...] contra o homem". 96

Na revista Domus, seria exaltada a ética nas instalações do Museu do MASP, ${ }^{97}$ então na rua 7 de Abril, no prédio de escritórios projetado por Jacques Pilon, que por não estar "instalado em prédio próprio, não [era] um monumento em si".98

O critério que informou a arquitetura interna do Museu restringiu-se às soluções de "flexibilidade", à possibilidade de transformação do ambiente, unida à estrita economia que é própria de nosso tempo. Abandonaram-se os requintes evocativos e os contornos, e as obras de arte antiga não se acham expostas sobre veludo, como aconselham ainda hoje muitos especialistas em museologia, ou sobre tecidos da época, mas colocadas corajosamente sobre fundo neutro. ${ }^{99}$

Ao "intransigente" arquiteto moderno caberia o trabalho que colocaria a nova arquitetura como "caminho para decência e à salvação para a humanidade". ${ }^{100}$ Afinal, mais importante do que construir era preciso saber como a maioria das pessoas vivem. ${ }^{101}$

93 Cf. Pagano Giuseppe. Architettura Rurale Italiana. Milão: Ulrico Hoepli, 1936.

94 Lina Bo Bardi, "Architettura e Natura: la casa nel paesaggio", Domus n.191, nov.1943:464.

95 Id. "Bela Criança", Habitat n. 2, op. cit .: 3

96 Id. "Casas de Vilanova Artigas", Habitat n.1, op. cit.: 2.

97 Os projetos de Lina Bo Bardi estampariam diversas revistas estrangeiras ao longo de sua atuação na Habitat. O Masp apareceria na The Architectural Review. (Setembro de 1952): 160-163 e Domus 284 (julho de 1953): 22-26; o Studio Palma na The Architectural Review (outubro de 1951): 261-262; o Museu de São Vicente na The Architectural Review (julho de 1953): 12-13 e, finalmente, a Casa de Vidro em diversas publicações: Domus n. 279 (fevereiro de 1953): 19-26, The Architect and Building News (23 de abril de 1953): 488-494, Interiors (maio de 1953):74-83; Architectural Design (agosto de 1953): 230-231; Werk 8 (agosto de 1953): 256-260 e L'Architecture d'Aujourd hui 49 (agosto-outubro de 1953): 38-41.

98 "Introduzione al Museo de Arte di San Paolo". Domus. n.284 (jul., 1953): 22-26. Este artigo

foi traduzido e publicado em Habitat, n.14 (janeiro-fevereiro de 1954): 52-53.

99 Lina Bo Bardi, "O Museu de Arte de São Paulo. Função social dos museus ", Habitat n.1, op. cit..: 17.

100 "Decoração", Habitat n.2, op. cit:91.

101 "Legenda", Habitat n.7, op. cit:95. 
A função do arquiteto é, antes de tudo, conhecer a maneira de viver do povo em suas casas e procurar estudar os meios técnicos de resolver as dificuldades que atrapalham a vida de milhares de pessoas. Para um arquiteto, o mais importante não

Hoje, em nenhum país do mundo se constrói relativamente mais do que no Brasil. E não é somente nas duas grandes Metrópoles, mas também nos centros afastados, nas margens periféricas, no limiar das florestas, nas extensões arenosas. Esse campo, portanto, poderia ser interpretado como fonte de cultura intensiva para a arquitetura de nosso tempo. Todas as circunstâncias econômicas e ambientais parecem, em muitos sentidos, favorecer a transformação de tantas experiências solitárias e exemplares, feitas aqui ou alhures, numa experiência comum, ou, antes, nacional. Construir a arquitetura moderna, a fisionomia do mundo de hoje. ${ }^{102}$

Na ética empregada na construção popular, a simplicidade derivada da racionalidade do fazer lógico contra a complicação irracional decorativa do gosto provincial, desvelaria uma consciência responsável, que não estaria subjulgada à moda e ao capital. ${ }^{103}$

"Não é verdade que o sentimento arquitetônico popular obedeça exclusivamente às estritas condições de sua miséria: às vezes, ao contrário, surge-nos ele mais rico de achados e soluções, mais cheio de lógica do que as deformadas estruturas inventadas pelos arquitetos em busca de sutilezas herméticas ou de formas extravagantes". 104

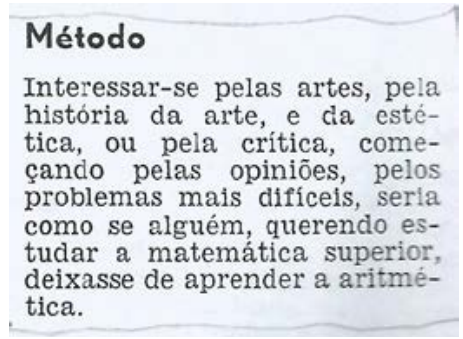

IMG 41.

"Método". [Habitat n.2, p.89]

102 "Construir com simplicidade", Habitat n.9, op. cit.:15.

103 No raciocínio da necessidade "os pobres são arquitetos, [...] não têm ideias extravagantes em relação à casa. Os pobres sabem quanto custa uma parede lisa; os ricos pensam em como completar uma parede lisa". In: "Porque o povo é arquiteto?", Habitat n.3, op. cit.: 3.

104 "O povo é arquiteto", Habitat n.10, op.cit, 32 


\section{Uma triste noticia}

Săo Paulo é uma cidade de cêrca de dois milhōes de habitantes, uma cidade que, como já tivemos ocasião de di zer em outras oportunidades. é nova no que se refere aos problemas da arte. Por problemas de arte entendemos todo o complexo de ativiclades artisticas que vâo de um bom desenho destinado à fahricacâo de uma colher, a arqu tetura de uma casa, de uma maquete para um de 70 ou 80 metros de altura os quais frequentede altura os quais frequentemente enchem as cidades, às páginas de um livro escolar ou de uma dessas contemporâneas tapecarias que sâo os cartazes; os problemas da sanato, das vitrines para comércio, do rádio para a televisão, ocupam toda a vida levisao, ocupam toda a vida de uma cidade. Dizendo que S. Paulo é uma cidade nova sob tal aspecto, nāo pretendemos afirmar que nāo se verificassem atividades artisticas no passado, mas simplesmente que depois da fundacão de instituições de arte, os problemas a que nos referimos foram realmente propostos e estão interessando o público (música, que comecara muito antes, tem hoje um desenvolvimento de que perfeitamente pode orgulharse uma metrópole)

$\mathrm{Na}$ nova cidade de $\mathrm{S}$. Paulo. há alguns anos passados, duas gentis criaturas, de pouco chegadas da Europa, haviam aberto uma galeria de arte, galeria nấo do gênero daque las nas quais improvisados comerciantes exibem um grupo Luiz Felipe e certa quantidade de falsificadas mobilias do estilo baroco brasileiro, mas, isso sim, uma galeria destinada a auxiliar os invens pintores brasileiros, alem de sua outra finalidade, qual seja, a de penetrar nos lares, fazendo-os aceitar um pouco de pintura que não seja exclusivamente a pintura exclusivamente a pintura das cartolinas ilustiradas, as quais grande parte das familias gosta de pendurar nas paredes domésticas, tomando evidentemente o cuidado de razé-las llummar de modo conveniente por meio de abatjours.

Tal era a confiança nos jovens pintores de São Paulo, confiança que ao mesmo tempo se baseava nos sentimentos estéticos de determinado grupo de amadores da arte, que a principio fingiam que o eram. depois passaram a uma pose snob, para finalmente descobrir na arte dos seus proprios contemporaneos qualquer coisa de satisfatorio, de agradável, de confortante (porque preciso lembrar que a generalidade dos paulistas ricos, que a noite voltam para casa satisfeitos com os bons negócios realizados, ou aborrecidos porque tais ativjdades náo lhes correram bem, está convencida de que a vida nâo se vive apenas gracas à loteria, aos jogos, ao futebol, as variadas formas de distracão: vive-se, isso sim, através da leitura de um livro, da músi-

IMG 42.

"Uma notícia triste" [Habitat n.8, p. 95]

\section{Odisseia}

José Siqueira no "O Jornal" (23 de dezembro) escreve: "Estamos plenamente convencidos de que o grande público e mesmo os amantes da música em nosso país, ignoram por completo a odisséla do compositor brasileiro da música erudita. Aqui, onde o sol nasce para todos, não há lugar para essa espécie de artista. É paradoxal!

A breve análise que faremos desse magno problema, reforca indubitavelmente, essa dolorosa afirmação. Quais sāo as causas determinantes desse descalabro?

I - A falta de educacão musical do povo, ocasionada pela má orientaçâo que vem sendo imprimida à essa forma de educacảo desde 1931, quando passou a fazer parte integrante do currículum das escolas primárias e secundárias em todo o pais; II - A falta de ambiente musical significativo, o qual existe somente no Rio e São Paulo, e, ainda assim, com grandes deficiências: III - A carência de casas editoras com âmbito nacional; IV - A indiferença com que as casas gravadoras de discos nacionais e estrangeiros tratam a música erudita brasileira; V - A falta de regulamentação da música, co mo profissão liberal; VI - O descanço com que são olhadas as produçōes brasileiras, quer pelas autoridades, quase sempre ignorantes na máteria, quer pelas diretorias das Sociedades de aficionados da música, quer pelos nossos próprios estabelecimentos de ensino, onde o compositor passa uma pequena existência, à cata de conhecimentos técnicos que lhes permita a prática conciente de sua arte $\mathrm{e}$, finalmente, a precáriedade de nossos teatros espalhados por todo o país sem organização juntos permanentes, como a orquestra, o cơro e o corpo de baile, sem os quais, resultará inutil qualquer tentativa de profundidade e largueza compatíveis com o Brasil de nos. sos dias".
IMG 43.

"Odisseia"

[Habitat n.6, p.94] 


\section{Ourivesaria}

O Brasil possue uma notável tradição no campo da ourivesaria, tradição absolutamente autônoma e rica de belas invençổes. No entanto, como vem sendo hoje em dia continuada esta tradição? Podemos logo dizer: da maneira a mais badizer da é, copiando mal sem nenhum, as formas antigas, ou pior ainda, experimentando falsificar as cousas antigas. $O$ balangandan, que originàriamente é uma soberba peca de ourivesaria, uma vez imitado ou na maioria dos casos falsificado, torna-se ancasos falso antigo é quanto sobra de uma situação gloriosa. Isto tudo acabaria se os ourives, inspirandose ao antigo, entendessem que o antigo há de ser germe de vida, estimulo para novas criaç̃os, para novidades originais çoes, para novidades originais a serem colocadas ao lado das antigas. Muito esperavamos da Escola de ourivesaria do "Senai"; no entanto, ai, onde o ofício é aprendido com tôda perfeição e diligência, o gôsto perfeicăo a está atrasado de, pelo "Salon, trinta anos: e o gosto do "Salon gôsto duvidoso e superado.

IMG 44.

"Ourivesaria".

[Habitat n.4, p.90]

\section{Fiorani}

Está morando no Rio de Janeiro um Jóvem que tem o gôsto da boa tipografia, isto é uma arte que vai decaindo dia a dia, descendo, allás na proporçâo inversa das conquistas técnicas que sáo pelo contrário, extraordinárias. tipografia passou das măos do artezáo ao escritorlo industrial, quasi que sem aviso prévio, de um ano para outro. Pode-se ainda encontrar al gum livro bonito, impresso no Rio de Janeiro, com carinho respeitando as normas bodonianas, consideradas o Evangelho dessa arte. Mas agora, o mau gosto domina. A nossa e a época da ofensa à tipografia, época em que os jornais usam letras maiúsculas para tôdas as palavras do titulo, consequência lógica do mau gôsto que nunca será do ficientemente deplorado. São tempos dificeis para o típógra fo que vem se dedicando profissăo desde jóvem, sem sua colas que the ensinem beto da mesma dum ponto de vista da tipografia artistica. no meio dessa confusclo, d confusão, do caos da paginaçáo apressada. debaixo de montanhas de papel impresso que perdeu quasi 0 aspecto de texto quem quiser imprimir um livrinho ou folheto obedecendo à arte tipográfica, não poderá fazer outra coisa a não ser chorar. A propria editorial do pais, em seu conjunto - pelo papel, ti elo papel, tipos, impressão, cliches e enpode ser levada a sério. pode ser levada a serio.

No entanto, no meio dessa desolaçáo, um jovem, Mario Fiorani, Imbuido de estudos humanistas, consegue fazer os prelos gemerem com uma razâo, um porque, um fím exclusivamente tipográfico. São as vozes da contra-corrente, quando a corrente é oceânica. E uma espécle de apostolato catequigador que náo quer talvez se dirigir as massas, e que vez se dirigir as massas, e que possue, no entanto profundo ignificado para os que vivem nao somente de paso, mas também de espirito. Todas as vezes que encontramos um desses voluntários do insucesso, somos levados a pensar que a atividade artistica é pura poêmica da inteligência contra a "casca-dura" do número infinito daqueles que, entre cavalos e futebol, loterias e Cadillac, leituras insignificantes e tro espetáculos carne de canhāo. Eis que Fiorani, para os votos de que Fiorani, para os votos le 1953 , envia uma composiço lpográfica bem cuidada, com boas tintas e papel que foi procurar até Pescia, onde ainda se fazem papeis à mão. São páginas tiradas de Max Ernst 'a êle dedicadas, a êsse artista menos popular do que um "rei da voz" ou um Ademir. Mas, os que receberem o foheto, sabem quem é Max Ernst i uma telegrafia sem los, que ninguém consegue inerceptar: é a linguagem da inteligência da cultura, da fantasia. E uma linguagem que, talvez, salvará o mundo

da chacina total.
IMG 45

"Fiorani"

[Habitat n.10, p.93] 


\section{Correspondência}

Muitos dos nossos leitores têm se queixado porque não respondemos mais, sob êsse título, àqueles que nós escrevem. Sim, o fato é que não temos mais recebido cartas, e por outro lado devemos confessar que as cartas dos números anteriores eram todas imaginárias.
IMG 46

"Correspondência".

[Habitat n.8, p.95]

\section{Declaração}

Passados já agora quatro anos da fundação desta revista, cujo escôpo foi proporcionar ao Brasil uma lide onde os muitos problemas das artes pudessem ser apresentados e debatidos tendo sempre em vista a necessidade indispensavel da crítica, os seus diretores e editôres podem se comprazer, hoje, com o longo e profícuo caminho percorrido e com o fato de na esteira de Habitat terem aparecido tantas outras revistas de arquitetura e arte. Mas qualquer esfôrço ou labor verdadeiramente apaixonado não pode prosseguir até ao infinito, principalmente no campo das artes onde a atividade deveras séria subentende uma polêmica. Ora, a nossa polêmica não pode perdurar mais, pois teríamos que repetir o que já foi dito e repetido, e acabaríamos nos tornando monótonos, deixando assim de in. teressar aos leitores. Por outro lado, motivos de viagem ligados ao itinerário prolongado na Europa e na América do Norte para a apresentação das exposiçôes das obras-primas do Museu de Arte de São Paulo e liga. dos à preparaçāo do novo plano do Museu impedem que Habitat possa contar com a nossa constante colaboração. Por isso, solicitamos aos editô. res desta revista que aceitassem as nossas demissöes.

Acreditamos que os quinze volumes da Habitat contêm em si todo um pa. norama bem como a perspectiva de bom movimento artístico brasileiro entendido sob o ponto-de-vista da avaliação dos seus artifices; procuramos defender as verdadeiras personalidades que operam no supradito panorama; diferenciamos sempre a arte da mundanidade; jamais incensamos qualquer indivíduo que, sem cultura e sem idéias, tenha tratado dos problemas da arte como assunto de botequim; nunca comparticipamos de excessivos otimismos sôbre a grandeza de certos arquitetos elevados a monumentos nacionais; jamais outorgamos diplomas à artistas após quinze lições; e assim por diante. Nossa atitude, por certo, pareceu extranhavel a certa gente afeita a se cansar em abracinhos. Mas quantos não serão os ver. dadeiros artistas, desde os artesãos índios até aos pintores primitivos, desde os simples contramestres até aos jovens arquitetos, que se beneficiaram com o nosso clima de revisões? Esperamos que continue esta liberalidade de Habitat e que os seus diretores saibam descobrir continuamente e com a maior cordialidade os novos valores da arte brasileira. Principalmente usando sempré da independência, sem dar ouvido aos vários "patrôes" que tanto existem no setor das artes como em quaisquer outros setores da vida. Agradecemos tanto às poucas pessôas que nos ajudaram nêste trabalho como aos editôres e proprietários da revista que souberam dar estrutura administrativa a uma publicação que as gralhas do mau agouro cuidavam que parasse de sair logo após o segundo número, conforme sói acontecer.

Lina Bo Bardi P. M. Bardi

IMG 47. "Declaração" [Habitat n.15, p.1 ] 


\section{$\mathrm{O}$ "BELO" - O DIREITO AO FEIO}

A expressão Kitsch surgiu na Alemanha no fim do Século XIX quando a Revolução Industrial tomou definitivamente o poder. É o estigma da alta burguesia culta contra os setores da mesma classe, menos afortunados que através da industrialização começavam a ter acesso aos "Tesouros da Arte", ao "Belo".

Esta pequena exposição não é uma - Integração do Kitsch - é apenas um pequeno exemplo do DIREITO AO FEIO, base essencial de muitas civilizações, desde a África até o Extremo Oriente que nunca conheceram o "conceito" de Belo campo de concentração obrigado da civilização ocidental.

De todo este processo foram excluidos uns ainda menos afortunados: o Povo.

E o Povo nunca é Kitsch.

Mas esta é uma outra historia.

LBB.

24 a 30/10/1082 - Centro de Lazer Sesc-Fabrica da Pompeia

I EXPOSIÇÃO DE ARTES DOS FUNCIONÁRIOS DO INAMPS

IMG 48.

O Belo e o direito ao Feio.

[Arquivo MASP].
IMG 49.

Colher.

[Revista Habitat]

ver algumas linhas de crítica e não de mero elogio jornalístico. A palavra "critica" é muito cacete, especialmente quando a empregam pessôas que a confundem com "dissecação"; mas é em nome da crítica que precisamos falar em arte, senão tudo se reduz a uma corrida de panegíricos e homenagens, corrida esta inútil tanto para o artista como para o público.

Eis o que foi uma mostra retrospectiva de Bruno Giorgi. Trata-se de um escultor com dotes plásticos de relevância, artista que possui o "métier" e a inteligência. Por vezes realiza pequenas obras primas, como o retrato de Mário će Andrade - vivo, ardente, pensado, quasi fértil —; mas ao lado de obras que enriquecem a escultura brasileira, encontramos trabalhos inexplicáveis, com algo de Henry Moore, por demais estra-

\section{A bela colher do indio Pariukur no Amapá.}

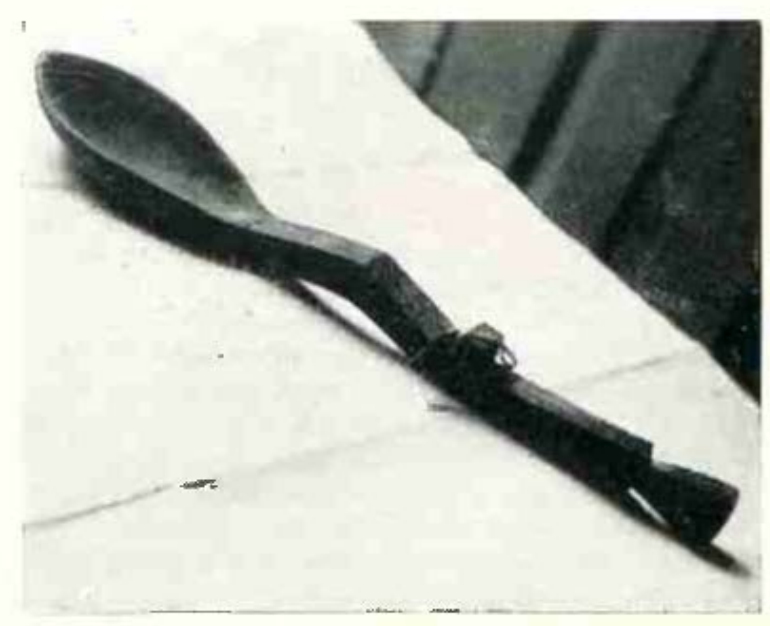


que o gênio, mais cedo ou mais tarde, despontará e dará seus frutos.

Lemos, porisso, com vivo prazer as seguin tes palavras no folheto de propaganda do "Instituto de Arte Contemporanea":

"Instituto de Arte Contemporanea" à arte "Formar jovens que se dediquem à arte industrial e se mostrem capazes de desenhar objétos nos quais o gôsto e a racionalidade das formas correspondan

Aclarar a conciênc a da funçẫo social do desenho industrial, refutando a fácil e detetéria reprodução dos estilos superados e do diletantismo decorativo.

Ressaltar o sentido da função social que cada projetista no campo da arquitetura aplicada deve ter em relaçăo à vida"” aplicada, deve ter em relaçảo à vida". Precisamos, néste caso, recomeçar tudo? Estamos tão atrazados em desenho industrial? (expressẫo feia, esta, inventada pelos americanośrcio mas na essencia significo o desenho na vida, gosto na atualifica 0 desen dace, o bom gostoj. Nas, nao estamos campo do industrial design" onde se encontra um Loewi, nenhum pais mais que os Estacios Unido ama a arte e se preocupa em sua integração à vida cotidiana. Encontramos, porém, ao lado de excelentes conquistas (por expl.: a forma da Studebaker, as geladeiras, os anúncios da revista "Fortune", a cadeide Charles ra de Charles Eames, os aparelhos sanita. rios Crane, etc.), uma infinidede de objetos mal desenhados ou até envelhecidos plágios, como é caso de certos móveis. dos estilos americanos, que sâo uma derivação direta dos estilos europeus, enfim. - incontrolável hibridismo dos fabricantes que só cogitam dos problemas especulativos e nunca dos estéticos.

No Brasil, os que fabricam nẵo se preocupam gersimente em aprimorar o gósto. O adjetivo "bonito" serve, indiferentemente, cer para louvar uma cadeir. a caricatura duma cadeira feita por um daqueles industriarios que, em matéria de gosto, ficaram no "bom gôsto" provinci ano. Assim acontece também na Itália, pais errôneamente acreditado como a quintessência da arte: os italianos pensam ter em suas veias meio sangue artista, com a certeza de ter arte no seu próprio corpo e pensam numa cançãozinha nacolitana mediocre, como pensariam em Bach.

dićto uso comum, indice correto para objero de uso comum, indice correto para julgar o nivel coteco de un povo, esta com alguns excmplares, sados, certamente, da letargia em que a pestifera repetiçào de estilos, chamad as tinha enfurnado.

Elizabeth Nobiling acaba de realizar no Mu seu de Arte 1 um album de ph faciaìo por José Geraldo Vieira.

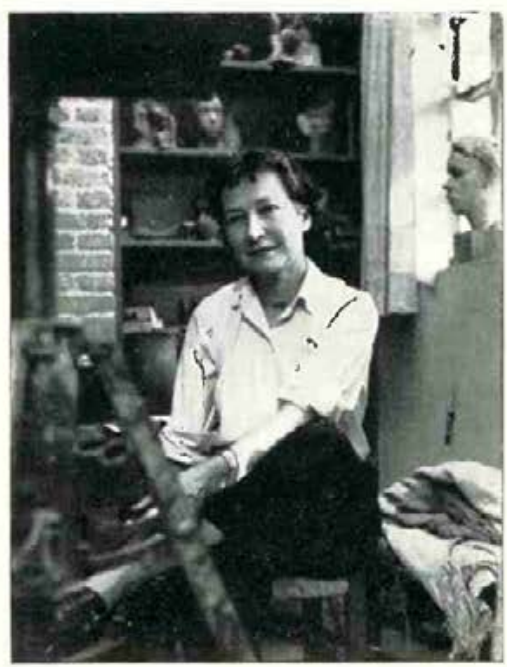

IMG 50.

"Desenho Industrial". [Habitat n.1, p.94] 


\section{[...] O povo se aborrece [...] com tudo aquilo que é inútil}

Para além da compreensão do "outro" como um sistema fechado, cuja atenção aos costumes e à cultura dos povos, serve enquanto perspectiva para se repensar o sistema e as categorias daquele que olha, Lina apresenta uma ação mais propositiva, do agir e transformar, pautada por uma visão de projeto que incide sobre a cultura material, na medida em que dela dependeria o nível estético do país. ${ }^{106}$

Quando aponta para a fatura de um "produto standart, usando a mesma precisão instrumental e funcional com que a inteligência do artesão fabricava seus produtos" ${ }^{107}$ Lina identifica não só a oportunidade reprodutível da indústria, mas o paradoxo inaugural imposto pela "coexistência desses dois sistemas de produção". ${ }^{108}$ Era necessário, ainda, que as soluções do desenho industrial fossem produzidas "com farinha do nosso próprio saco". ${ }^{109}$

[...] Os jovens de São Paulo expuseram-me sua tese: "Somos antropófagos". A antropofagia não era um costume glutão. Tratava-se do rito esotérico, de uma comunhão com as melhores forças. $O$ repasto era parcimonioso, dele participavam cem ou quinhentas pessoas que iriam comer a carne do inimigo capturado. Esse guerreiro era valoroso; assimilavam-se

\footnotetext{
105 "O povo é arquiteto", Habitat n.10, op.cit, 32.

106 "Desenho industrial", Habitat 1, op. cit.

107 "Artezanato e Indústria", Habitat n.9, op. cit, p.86.

108 Ibidem.

109 Alencastro, "Desenho Industrial", Habitat n.4, op. cit: 95.
} 
suas virtudes, porém ele, por sua vez, havia comido a carne dos próprios guerreiros da tribo. Assim ao comer sua carne, assimilava-se a própria carne de seus ancestrais. ${ }^{110}$

Transposta para a questão cultural, a saída antropofágica de Oswald que, ao mastigar e digerir o outro, assimila sua potência em estado bruto conduziu a cultura brasileira dos anos 1920 aos 1960, perspectivada do erudito ao popular, "entre a sedução da cultura ocidental e as exigências de seu povo, múltiplo nas raízes históricas e na dispersão geográfica"."'11 De forte carga simbólica, a via antropofágica equacionou o movimento construtivo europeu às vanguardas nascidos no Novo Mundo, na tensão que abriga o olhar para dentro e para fora, ao mesmo tempo, formalizando um fazer antropofágico contido no que se produz e, sobretudo, como se produz. E, assim, nesse léxico cultural permeável, se os sistemas teóricos europeus perspectivaram a cultura brasileira, o velho continente também pôde, a partir das "transplantações possíveis", rever a ideia constituída de si mesmo.

No exercício do gosto moderno, a experiência popular seria vista como catalisadora do processo de consolidação cultural a partir da ética social desejada e sua projeção no "concerto universal das nações". ${ }^{112}$ Ciente da vastidão do território brasileiro e da multiplicidade não apenas de expressões, mas de estágios de industrialização muito distintos em sua proporção continental, refletidos na produção da vida material do país, a engenhosidade própria e genuína das manifestações populares em suas necessidades cotidianas continha uma ética que poderia, assim, balizar um método reprodutível, no qual residiria a autenticidade da experiência moderna.

Nos últimos anos em que Lina viveu na Bahia, no começo da década de 1960 , a arquiteta se dedicaria ao Centro de Estudos do Trabalho Artesanal / CETA, que estaria em correspondência com a criação de uma Escola de Desenho Industrial, cuja produção se daria na esteira de objetos-tipo para a indústria, a partir do entendimento de um método pedagógico que fosse capaz de fazer a passagem do pré-artesanato existente à indústria.

Em seu plano de ação, haveria um intercâmbio entre projetistas, vindos dos cursos de Engenharia ou Arquitetura, e mestres-artesãos, numa formação intercambiável, considerando, inclusive a necessidade de formação dos últimos, oriundos de um estágio pré-artesanal. Para o escultor Mário Cravo, que integrava o circuito do Museu de Arte da Bahia, o conceito do mestre-artesão desapareceria no movimento de integração à cultura industrial.

[...] veja bem: o conceito é que se vai desaparecer, se essas manifestações populares têm que desaparecer, por que não aproveitamos de alguma forma e assassinamos-las? É isso aí, conscientemente. Eu acho que é um raciocínio válido. E então de certa forma, trazer esses mestres para a cidade foi uma maneira de sacrificá-los [...] você trazendo esses mestres para cá, eles seriam automaticamente poluídos e transformados, é uma maneira de matar. ${ }^{113}$

110 Le Corbusier. Precisões: sobre um estado presente da arquitetura e do urbanismo. São Paulo: op.cit., p.29.

111 BOSI, Alfredo. História concisa da literatura brasileira. 3.ed. São Paulo: Cultrix, 1981, p. 345.

112 Lina Bo Bardi. Catálogo Brennand Cerâmica. Museu de Arte Moderna da Bahia, 1961.

113 Entrevista do escultor Mário Cravo ao professor Renato Ferraz, em 06/10/2000, reproduzida em Pereira, Juliano Aparecido; Sobral Anelli, Renato Luiz. "Uma Escola de Design Industrial referenciada no lastro do pré-artesanato: Lina Bo Bardi e o Museu do Solar do Unhão na Bahia". Revista Design em Foco, vol. II, núm. 2, julho-dezembro, 2005 , p.24. 
A morte do artesão ou do "pré-artesão", na definição de Lina, diz muito sobre as resistências impostas ao seu projeto pedagógico, inclusive em seus círculos mais próximos. Mas é no sentido de primeiro da antropofagia - a "eleição do prato" "114 - que sua práxis vai ao encontro da máxima oswaldiana. Ou ainda, nas palavras de Suzuki, na estratégia que "mistura e manda":

Mistura e manda, também é expressão popular corrente para designar o jeito brasileiro de comer, arroz com feijão e farinha, carne seca: mistura tudo e manda, e, quando dito, é sempre acompanhado do gesto de se levar um garfo à boca, mas um gesto feito brusco, desaforado. Mistura também é o que é mais caro - de preço e de sabor durante a refeição: arroz, feijão e farinha a base, carne - boi, galinha, cabrito - é a mistura - mesmo quando carnes "de-segunda": bucho, fato, como se diz na Bahia. Na música brasileira, misturar e mandar pra-dentro, mastigar, comer e engolir, sempre foram salutares: há influências de todos os tipos e procedências. $\mathrm{Na}$ arquitetura moderna brasileira isso também ocorreu, ou melhor, foi assim que foi nascendo, trazida ou colhida na fonte, não importa. ${ }^{115}$

Interessa, portanto, mais do que aniquilar o outro, preocupação de viés culturalista, a ideia de projeto na chave da invenção. ${ }^{116}$ Mais próxima, portanto, da antropofagia do que da etnografia, ao inventar o prato e seus elementos "culturalmente válidos", Lina reinventa a si mesma, enquanto produtora de uma história que lhe diz respeito: a cultura material brasileira e suas possibilidades de produção, circulação e transmissão.

\footnotetext{
114 Luis Antônio Jorge, em sua comunicação enquanto presidente da banca para obtenção do título de livre-docente do professor $\mathrm{Dr}$ Guilherme Teixeira Wisnik. FAUUSP, 2019.

115 SUZUKI, Marcelo. Lina e Lucio. Tese de Doutorado. IAU-USP, 2010, p. 284.

116 Luis Antônio Jorge. "A posse possuída: o encontro marcado com o sertão". Em Espaço Seco: Imaginário e poéticas da arquitetura na América. Tese doutorado. FAUUSP, 1995, pp. 69-183.
} 

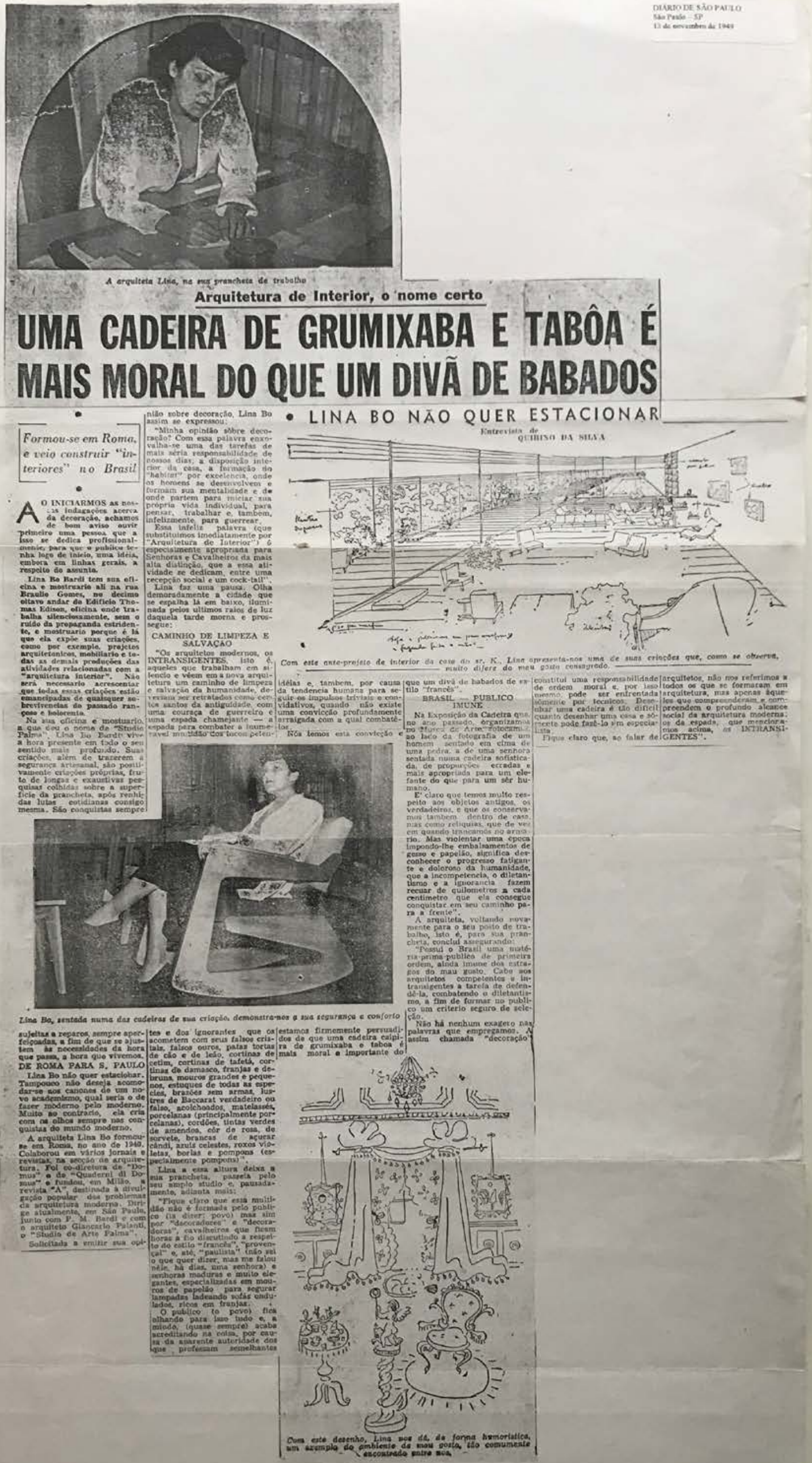


\section{Paradoxos da industrialização}

No Brasil, em meados dos anos de 1950, com o fim do Era Vargas, retomava-se a vida democrática do país e no âmbito econômico, o processo de industrialização se abria em nova perspectiva, via indústria automobilística e expansão da infraestrutura, pautadas pela necessidade crescente da modernização. Entretanto, o país - e a América Latina como um todo - encontravam-se em enorme defasagem diante dos países industrializados.

Os anos 1950 marcariam não só intensa industrialização em busca de consolidação, mas a criação de um mercado dinâmico, que resultaria num projeto modernizador capaz de entender a economia como um todo. Essa análise partia da constatação de que a modernização, na primeira metade do século XX, acentuou descompassos regionais sob a forma assincrônica de seus motores de desenvolvimento. Ao Norte, o poder se concentrava numa aristocracia rural, detentora das terras e dos meios; ao Sul, às benesses se acumulavam em uma recente burguesia industrial - ambas conservadoras e em cuja base estaria uma população depauperada.

Neste período em que o país vivia um processo acelerado de sua modernização, surgem diversas instituições cujo propósito estava em gerir o desenvolvimento nacional, como o Conselho Nacional de

IMG 51.

"Uma cadeira de grumixaba e tabôa é mais moral do que um divã de babados". [Diário de S.Paulo, 13 de nov. de 1949].
Desenvolvimento Científico e Tecnológico - CNPq, em 1952, o Banco Nacional de Desenvolvimento Econômico - BNDE, em 1952, a Petrobrás em 1953 e a Eletrobrás, 

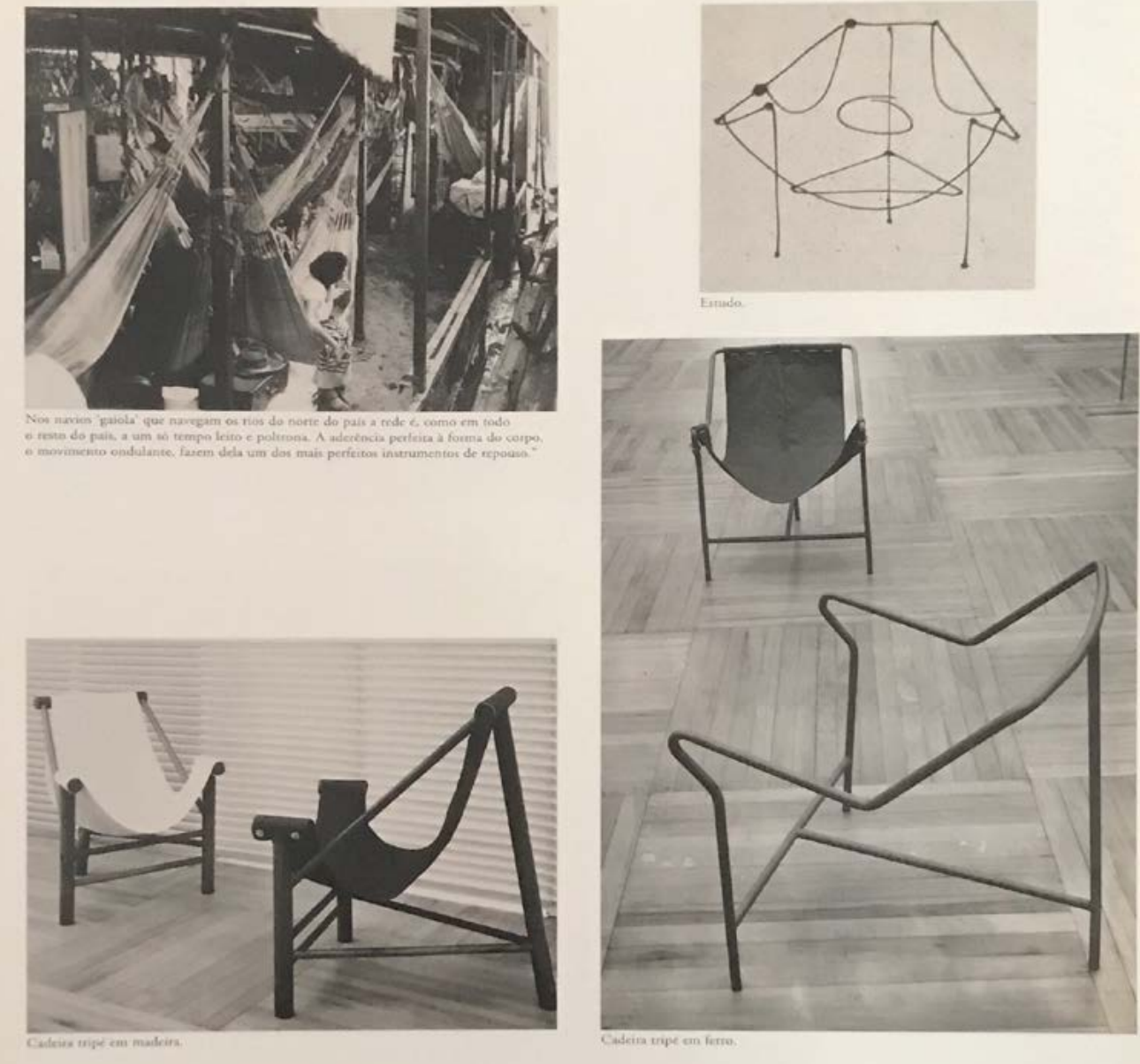

em 1954. ${ }^{117}$ Formalizava-se, assim, um debate acerca dos valores e instituições necessários para que a noção de modernidade estivesse perspectivada por uma ideia de progresso. Evidentemente, a associação parasitária entre investimentos públicos e privados tenderia à concentração de riqueza e o horizonte de sua democratização gerando progresso se tornaria uma miragem no oásis do planalto central do país.

Mas de volta a esse hiato democrático ou, melhor dizendo, em redemocratização, que emerge a discussão acerca da institucionalização do design no Brasil. $\mathrm{O}$ reconhecimento do atraso exponenciado em Brasília somado à necessidade de promover seu desenvolvimento, levaria a um debate público acerca da industrialização e às consequentes tentativas de sua institucionalização através das escolas que emergiriam no início da década de 1960, pensadas sobretudo para inibir o processo de pagamentos de 'royalties' pelo uso da forma em produtos fabricados no Brasil. Era, portanto, necessário repensar a produção e distribuição de objetos-tipo num cenário de desenvolvimento acelerado, a partir de políticas públicas de incentivo à produção nacional, visando à substituição

117 Essas novas instituições estatais somavam-se ao processo iniciado durante o Estado Novo,

representado pela criação da Companhia Siderúrgica Nacional, em 1941, a Companhia

Vale do Rio Doce, em 1942 e a Companhia Nacional de Álcalis, em 1943. 


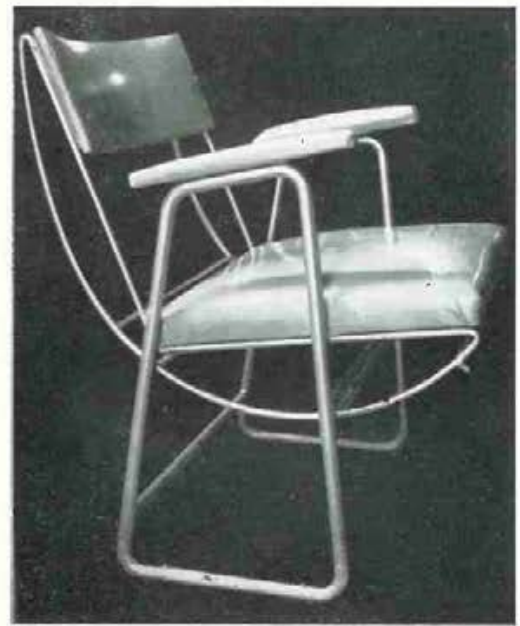

A cadeira do grande auditorio; assento encosto estofados $\theta$ cobertos com material plástico plavinil cinza perola; as partes de ferro säo pintadas de bronze de aluminio.
A cadeira do grande auditorio é movel, permitindo que se ganhe notavel espaço. O encôsto $e$ o assento, fixados sobre uma armaçáo de tubos de aço, em curva semi-oircular. giram mediante um impulso transmitido ao assento, para cima. A armação rotativa fiviala num oavalete de forro $\mathrm{em}$ que são fivader os bracos; aterais permitem a armasao de nodar sem jugir ao cavalete de Jerro. A pessoa sentada transmite - impulso ao assento que, levantando, per mite a utilizaçāo maior do espaço numa posiçáa de comodo reouo. Patente arq. Lina Bo Bardi.

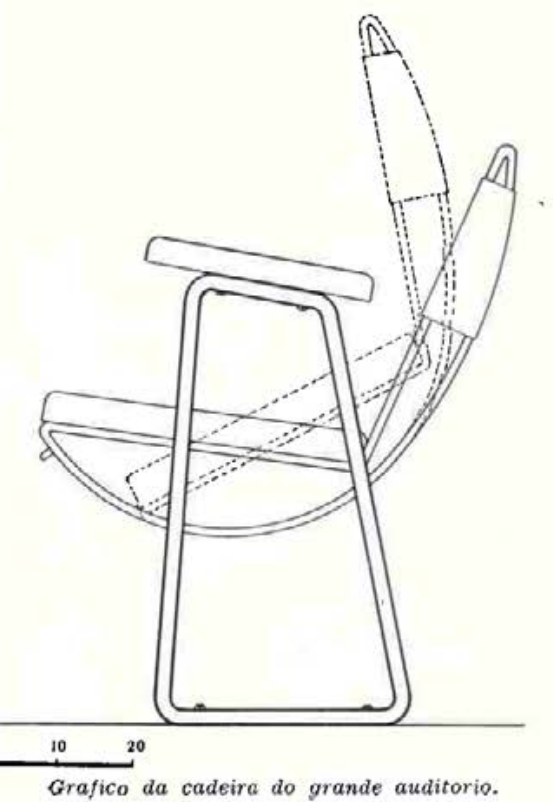

dos produtos importados e, mesmo, a nacionalização da forma.

Próxima à sede do Masp, no centro de São Paulo, ao final dos anos 1940, Lina abriria o Studio de Arte e Arquitetura Palma junto ao arquiteto Giancarlo Palanti, ${ }^{118}$ que além de projetos de espaços internos cuja aceitação comercial seria evidente, o studio pautava-se, antes, em desenvolver a prática do design no Brasil, a partir de móveis consonantes aos tempos modernos. Lina relataria que "não existia uma preocupação com o desenho industrial no Brasil, apenas um artesanato e alguns decoradores tipo 'Plaisir de France' [...] uma coisa de direita, reacionária." $" 119$

Em suas instalações, haveria uma área artesanal, aos moldes de uma oficina de madeira e uma pequena indústria para que se pudesse realizar os protótipos. ${ }^{120}$ Essa associação era condição necessária para execução, uma vez que a produção exigia a manipulação artesanal, dada a inexistência de uma estrutura industrial

118 “Uma significativa exposição de 'Nós e o Antigo'. Um Studio de arte no alto de um arranha-céu. Diário de São Paulo (8 de agosto de 1948).

119 MENEZES, Aureliana. Entrevista com a arquiteta Lina Bo Bardi. FAU-USP, 20 de agosto de 1976. Arquivo ILPMB.

IMG 53.

Cadeira tubular do grande auditório do MASP. 120 Ibidem. 


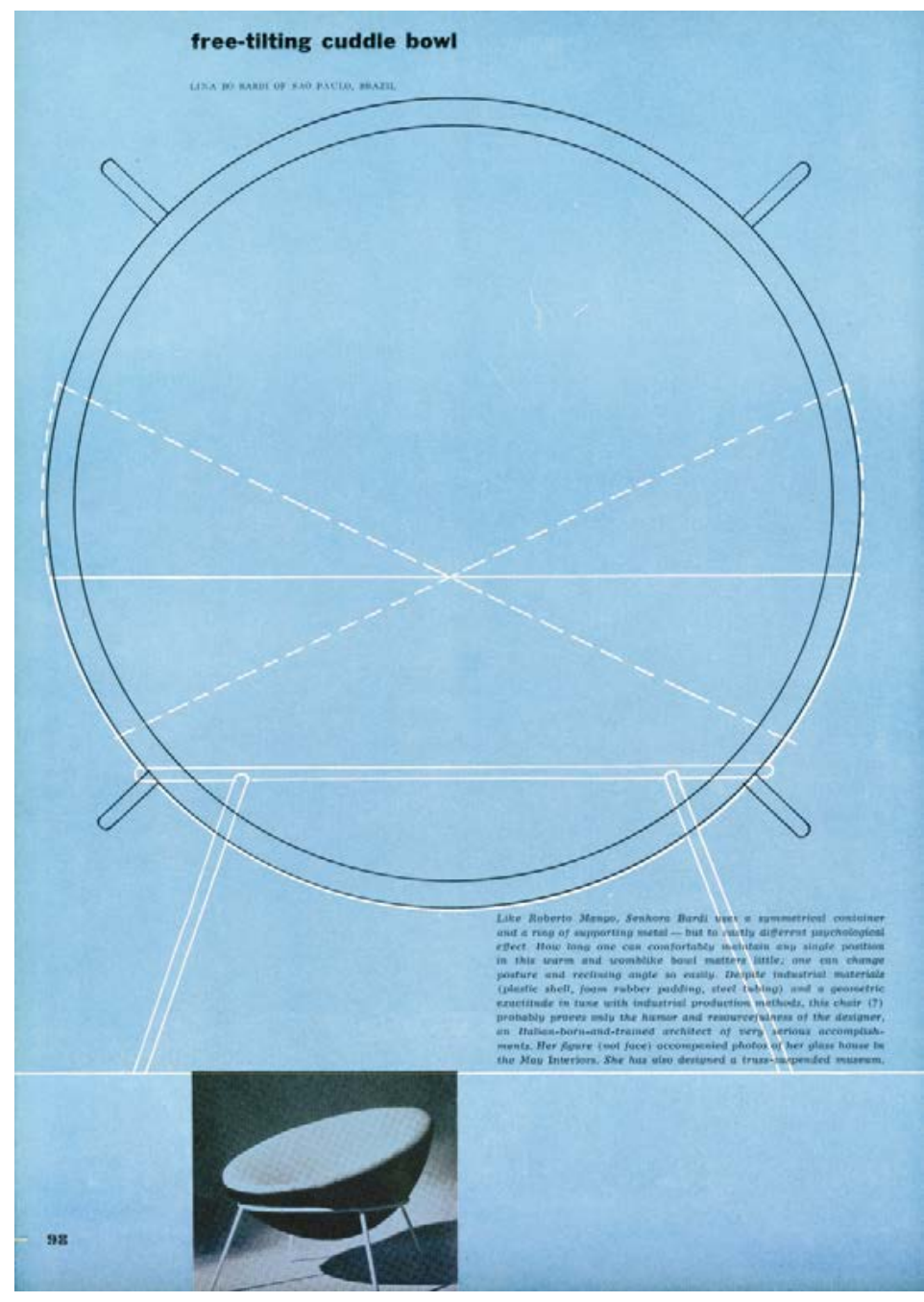

IMG 54.

Bardi's Bowl.

[Interiors, mai. de 1953.] capaz de produzir em larga escala, o que naturalmente, acabou se tornando o avesso da produção em série, com alto custo por unidade.

No Brasil não existe modulação nenhuma porque não existe uma produção industrial para construção, nem nos móveis, nem na arquitetura. [...] Toda a produção que tem aqui, é um quebra-ganho de $4^{\mathrm{a}}$ categoria, sem uma indústria de base verdadeiramente séria. ${ }^{121}$

Em sua primeira tentativa de produção de uma cadeira moderna, Lina colocaria na legenda do livro que condensaria suas obras, em 1992, um parêntese elementar: (embora não industrial) $^{122}$ Resultariam, dos tempos do Studio Palma, duas cadeiras: uma para o auditório menor do MASP, em 1947 - feita à mão pelo artesão italiano Renato Consolaro, ${ }^{123} \mathrm{em}$ madeira brasileira e assento em couro; a outra, para o auditório maior, tubular com assento em plástico - também de produção manual. Problema semelhante enfrentado, anos antes, por Warchavchik, relatando para Siegfried Giedion, na ocasião do III CIAM, ter que montar "ateliês para que fossem executadas janelas, portas de madeira lisa, móveis etc, porque a indústria, que aliás trabalha bastante bem para a construção comum, não pôde realizar o que eu lhe pedia com a precisão e o cuidado necessários". ${ }^{124}$

Além da inexistência da indústria para amparar a produção em massa, a falta de propriedade intelectual de seus desenhos, com cópias muito rapidamente disseminadas sem qualquer critério de qualidade em sua apropriação e execução, ${ }^{125}$ fez com que Lina e Palanti fechassem as portas, antes mesmo de adentrar os anos $1950 .^{126}$

MENEZES, Aureliana. Entrevista com a arquiteta Lina Bo Bardi. FAU-USP, 20 de agosto de 1976. Arquivo ILBPMB.

122 "Studio Palma", em Lina Bo Bardi, 1992:56.

123 Pietro Maria Bardi, História do MASP, op. cit. 13.

124 Ver Gregori Warchavchik. Arquitetura do século XX e outros escritos. São Paulo: Cosac Naify, 2006, p.171.

125 MENEZES, Aureliana. Entrevista com a arquiteta Lina Bo Bardi. FAU-USP, op.cit. Arquivo ILBPMB.

126 Júlio Katinsky, que frequentou o curso de desenho do Masp aponta que o estabelecimento do desenho industrial no Brasil inicia-se com a produção da arquitetura brasileira dos anos 1930-40, com a limitação de importação de materiais como cimento e aço, ao longo da Segunda Guerra Mundial, o levaria ao desenho de componentes como esquadrias, azulejos, cobogós e mobiliários. Ver KATINSKY, Júlio Roberto. Desenho industrial e artesanato [Apresentação] Design brasileiro: quem fez, quem faz[S.I: s.n.], 2005. 
Porisso, nào se irrite o leitor com a tirada do "bonito"; todo o mundo é como uma grande província e nós, no Brasil, temos a sorte de estar num pais jovem, e ainda por fazer.

Muitos passos já foram dados, A influencia ios proditos amer muito objétor. A arquiletura do grupo de Jovens arquitetos brasileiros e dos extrangeiros aqui radicados, como a difusảo das conquistas estéticas, realizadas cotidianamente através de revistas e cinema, ajudam a discernir. Se, por exemplo, a nda existem familias que manciam construir seu palacetc em estilo colonial com no seu incerior uma farra decorativa digno do colonigl da fa farra decorativa digna do chan (acuelas paredes de banheiro, chamadas do azulejos, com figlurinhas pintadas por moças amadoras de bôa família), se bem que isto ainda exista, temos já as çasas que não caem nas mãos dêsses decoradores de gôsto duvidoso e fantasista. O fato mesmo de já existirem fábricas de moveis inspiradas nas melhores producões americanns e curopéias, significa que brevemente morrerão de morte natural êsses monstrengos deslocados em época e lugar: as perninhas recurvadas a Luiz XVI ou à as perninhas recurvadas a Luiz XVI ou à D. Joào V1, os dourados com purpurina, thas, as cortinas que varrem o chảo e os tapetes de falso Oriente, os bibelos falsificados etc

Nas casas tomarão naturalmente seu lugar os móveis simples, cômodos, proporcionados, isto é; os móveis estudados e desenhados; nas vitrinas ver-se-ẫo objetos que adornam e se pensará que sua origem está no bom desenho, executado por alguem que estudou, percebeu, compreendeu, sôtre as pareces veremos cartazes agradáveis, vivos, expressivos: assim a própria rua, sala de recepcão da cidade, tera seus aspectos de recepção melhorados

Virá tal dia, mas para isso devemos trabalhar. Os numerosos industriais responsáveis pelo ramo, devem pensar neste problema, pois é também o problema de novas produçoes: pois a um certo momento haverá uma tal repugnancia pelo velho e falso que o público exigirá algo de novo. A producão antecipada desde jó dêstes A produção antecipada, desde ja, destes nova que nầo renovam o tipo de sua produção desde a primeira guerra mundial! Quando alguem deseja adquirir um objéto qualquer para presente, para tal se dirige a rua Barão de Itapetininga, poderá perceber quanto é tomada a estética em consiGeração! Há all uma bóa loja com mercadoria, em sua grande parte estrangeira observando estes objétos, por vezes lindos, pensamos que êles poderiam ser produzldos pelo artesa pelo artesanato paulista se. Mas, alem desta loja, quanto briquea-braque? Residuos de ceramicas do pior oitocentos, prataria dita portuguésa, que mais parece brazōes de tubarôes, os móveis para rádio que nacia mais săo além de exercícios da pior marcenaria para os sentenciados que um d'a terâo seu funeral sob um daqueles absurdos campanários da Consolaçảo e da Avenida Brasil, que chamam por vingança. $\mathbf{E}$ assim por diante. Criticar não adianta. Prec'sa-se lançar ns bases para um novo espirito, para novo clima, e é neste sentido que se está trabalhando. "Habitat" sentir-se-á satistrabalhando. "Habitat" sentir-se-á satis-
feita em anotar e divulgar torios os esfor-
cos informados por este intúito.

\section{Decoradores}

Para se ter uma idéia dos pensamentos que presidem à decoraçâo oficial. é suficiente dar uma olhadela nos lustres que enfeiam - teto da passagem subterrânea da Praça da Correio, em São Paulo.

\section{Abramo}

Livio Abramo é um requintado gravador, pode-se dizer, o primeiro a gravar no Brasil: um subtil observador da natureza e dos

IMG 55.

"Desenho Industrial"

[Habitat n.2] 


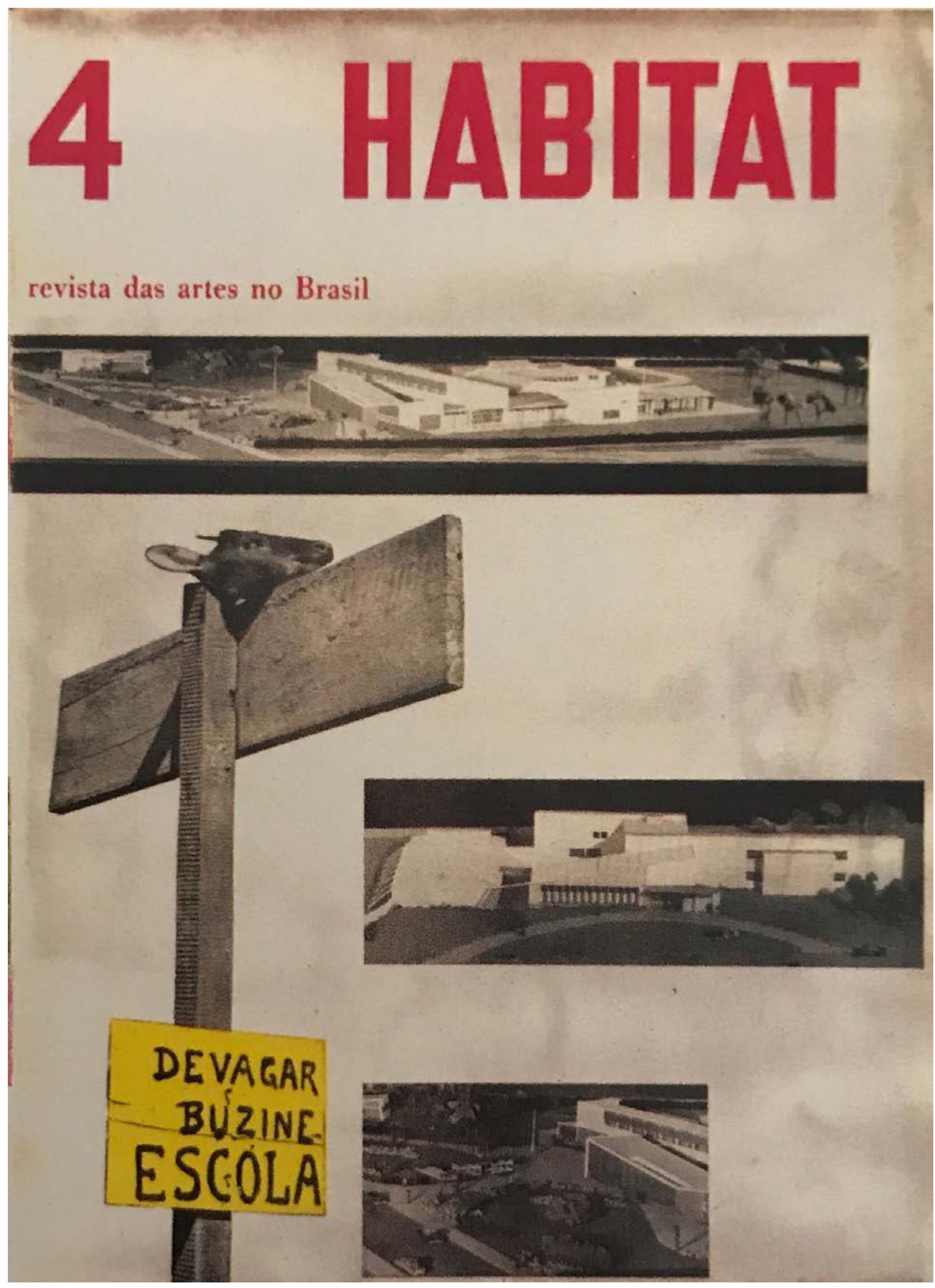




\section{Com a farinha de nosso saco}

Com o objetivo de "esclarecer a consciência do papel social, do projeto indústria, refutando a fácil reprodução e superar deletéria de estilos decorativos e diletantismo. Destacar o significado da função social que cada projetista, no campo da arquitetura aplicada, deve ter em relação à vida" ${ }^{127}$ o Instituto de Arte Contemporânea seria inaugurado, em março de 1951.

Mesmo antes, o Masp organizaria diversos cursos de caráter experimental, ${ }^{128}$ entre história da arte para público geral e monitores, vitrines, música, dança, cinema, gravura, musicologia, filmes, fotografias e educação para crianças e, em parceria com instituições de ensino, promoveria oficinas educacionais. Para crianças de 5 a 12 anos, seriam ministradas aulas de pintura, escultura, dança, música, fantoches e música. O Masp formaria, ainda, duas orquestras: de crianças e jovens, oferecendo ingressos a programas de bolsas de estudo, além do Conjunto de Dança Expressiva, dirigido por Yanka Rudzka, que mais tarde faria parte da vida cultural na Bahia.

O ensino abrange a fotografia, jardinagem, tecelagem, artes gráficas, moda. Porque este é o espírito fundamental da escola. O Museu procura antes de mais nada, formar esses elementos que, como no passado, aproximam a arte e o costume:

\footnotetext{
127 "Industrial Desenho", Habitat n.1, op. cit. : 94

128 Pietro Maria Bardi. An experimental education. Museum, vol, :3 e 4; e "Eleazar no Museu de Arte", Habitat n. 12 (julho-setembro de 1953): 89.
} 


\section{MUSEU

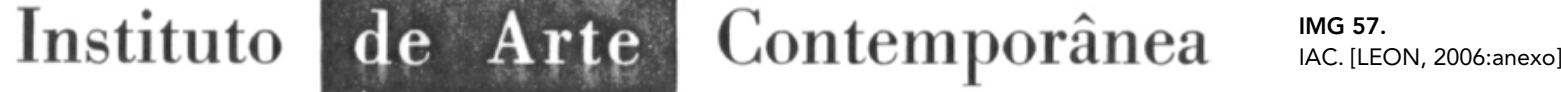

0 Institutó de Arte Contemporànea surge por iniciativa do $\mathbf{M u}$. seu de Artes de São Paulo, com a finalidade de colocar à dis. posiçáo dos jovens uma escola e um centro de atividade, onde seráo estudados e divulgados os principios das artes plásticas em favor da coletividade e em absoluta coerência com a época.

Um grupo de arquitetos, artistas e téenicos, persuadido da ne. cessidade dessa inichtiva, reuniu-se com o objetivo de trabalhar nessa escola rigorosamente disciplinada e orientada numa base didática, visando:

- formar jovens que se dediquem d̀ arte industrial ê se mos. trem capazes de desenhar abjetos nos quais o gosto e a ra. cionalidade das formas correspondam ao progresso e à men4. talidade atualizada;

- T. aclarar a consciêncio da fungüo social do desenho indus. trial, refutando a facil e deletéria reprodução dos estilos su. - perados e o diletantismo decorativo;

- ressaltar o sentido da função social que cada projetista, no campo da arte aplicada, deve ter em relaçäo à vida.

Em uma palavra o I.A.C., solicitando a colaboração definitiva da indústria, deseja inerementar a circulaçáo de idéias novas, de novos empreendimentos no campo estético, errôneamente considerado como storre de marfims para inieiados, generalizando o mais possivel as conquistas da arte, da tradiçáo e da cultura.

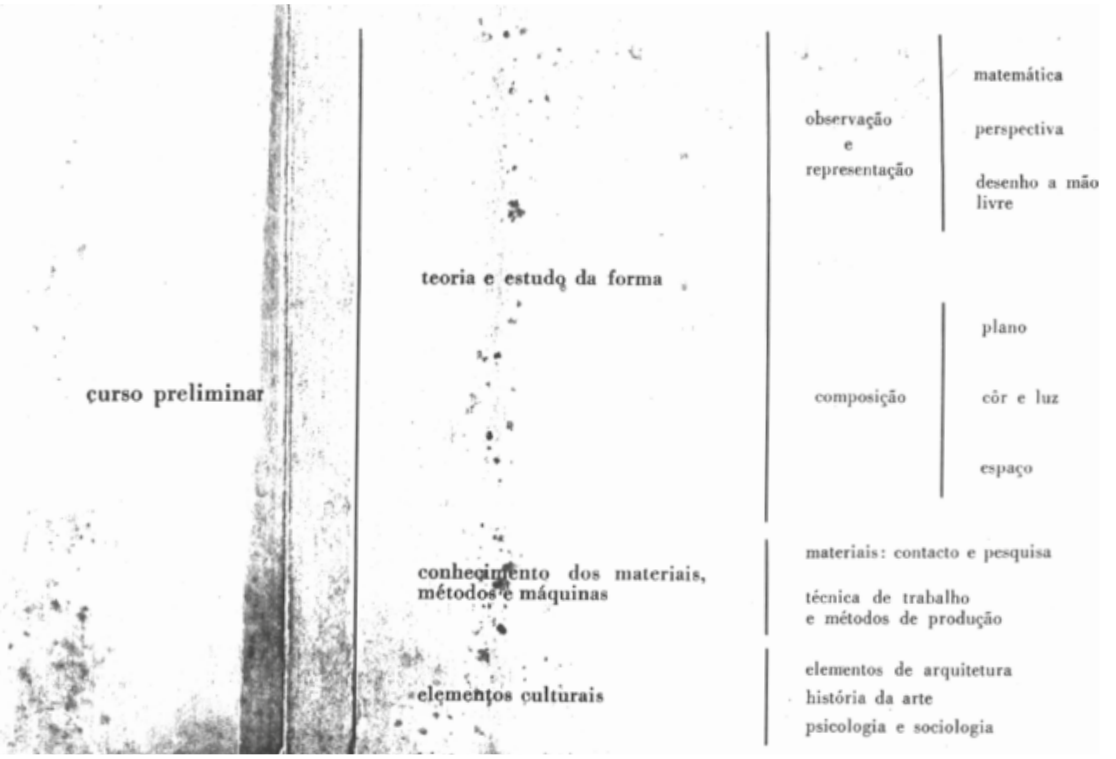

IMG 58.

Projeto Pedagógico IAC.

[LEON, 2006:anexo]
IMG 59.

Projeto Pedagógico

IAC. [LEON

2006:anexo]

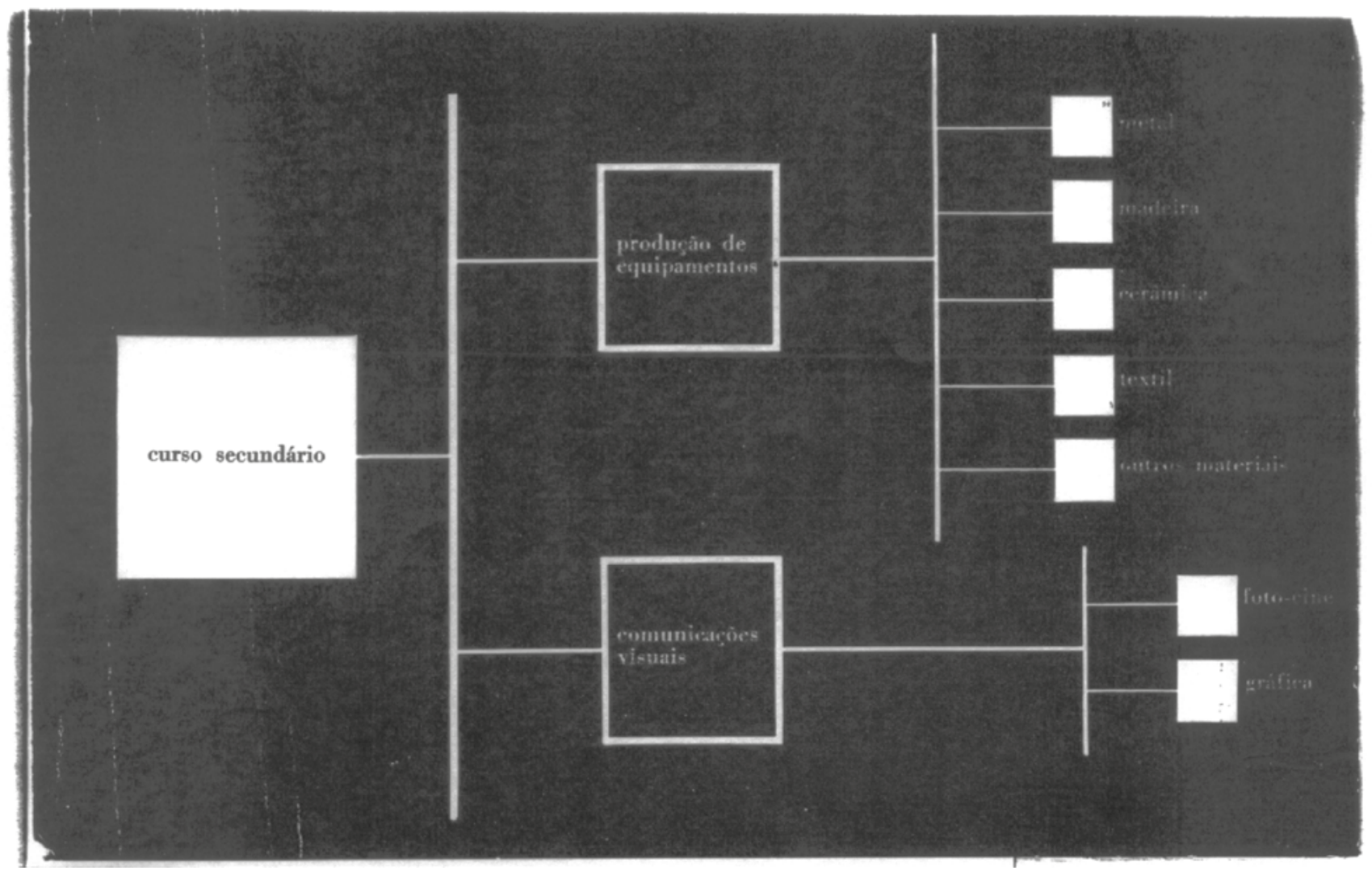




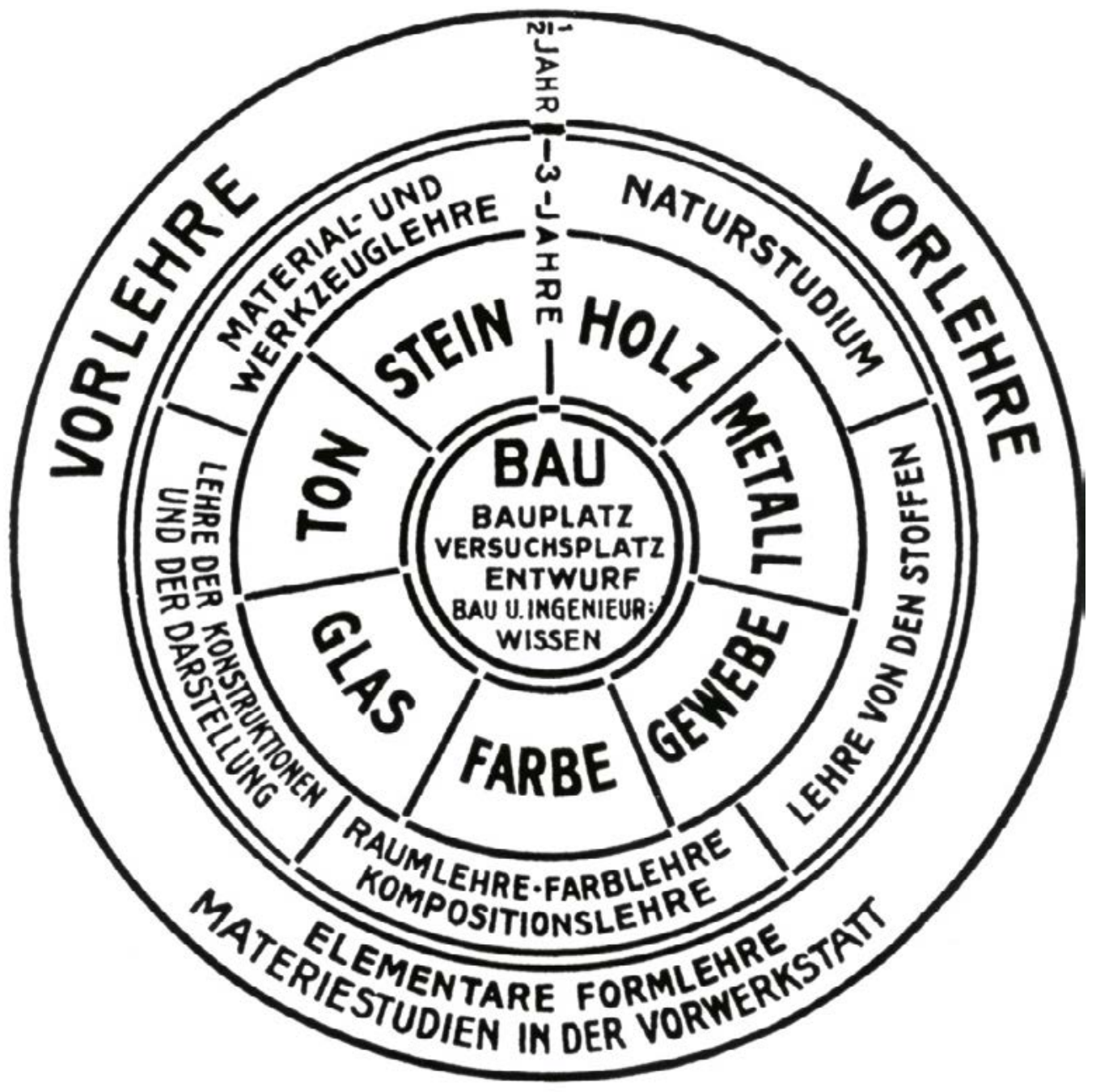

pretende penetrar no gosto da nação, não mediante a alta cultura que artificialmente diferencia as classes, mas através de verdadeiras "atividades penetrantes", como o desenho industrial, a propaganda [...] com "speakers" de rádio e cenógrafos de televisão, com a moda, as artes gráficas, a decoração, as profissões do artesanato, isto é, com atividades positivas que determinam o gosto e o costume. Tudo isso relaciona-se com as classes sócias. Portanto - Museu não é uma escola "popular" (no antigo sentido classista de elevar uma camada do novo ao gosto burguês) mas uma escola nacional, aberta, em primeiro lugar, à juventude, aos moços. ${ }^{129}$
IMG 60.

Projeto Pedagógico Bauhaus. [Bauhaus Archiv.] 


\section{Desenho industrial}

Fabricantes de cerâmica, de móveis, de vidros artísticos, de adornos em geral; fabricantes de tecidos, fabricantes dos mil objetos de gosto atrazado e de desenhos furtados cá e lá! oucam: demos a São Paulo a primazia no campo do desenho industrial, e criamos as formas com a farinha de nosso saco.

IMG 61.

"Desenho Industrial".

[Habitat n.4, p.95]

Pensando no ensino, autonomia e disseminação do desenho industrial e das artes aplicadas em bens de consumo de origem industrial, em março de 1951, seria inaugurado o Instituto de Arte Contemporânea IAC, no mesmo prédio do Museu, contendo laboratório de fotografia e oficinas de tecelagem, gravuras, metal, gesso e madeira, cujo funcionamento se estenderia até final de 1953. ${ }^{130}$

Aos alunos do IAC ficaria as instruções de Alencastro para "esquecer quanto aprenderam e considerá-lo como experiência negativa; isto porquê, na maioria dos casos o ensino teve seus epicentros nas imitações de modelos antigos [...] Uma escola de desenho industrial que está em início, não pode prescindir da realidade do Bauhaus e do afamado Instituto de Chicago". ${ }^{131}$
Surgiu então a famosa 'Bauhaus' com Gropius, Breuer e outros, a escola de desenho industrial criadora de inúmeras soluções novas que hoje nos são familiares como as cadeiras de tubo de aço, moveis de aço etc. Depois os americanos continuaram e desenvolveram essa experiência no conhecido Institute of Design de Chicago, chefiado por Moholy-Nagy, ex-professor da Bauhaus.... Todas essas iniciativas não podem passar ignoradas no Brasil, principalmente em São Paulo, grande centro industrial. Hoje a arte não pode mais ser vista como especialidade de um grupo fechado. Ela tem que ir ao encontro dessa transformação da fisionomia do mundo feita pela indústria e nas mesmas proporções. ${ }^{132}$

130 Lina Bo Bardi, "O Museu de Arte de São Paulo. Função social dos museus ", Habitat n.1, op.cit.

131 "No Museu de arte. Instalação do Instituto de arte contemporanea.", Diário de São Paulo, 8 de março de 1950. Arquivo MASP. 132 Ibidem. 
A configuração do campo intelectual para o design enquanto atividade profissional $e$ suas possibilidades no contexto brasileiro da concepção à produção da cultura material, levaria a profundas discussões acerca de sua prática, seus modos de produção entendendo aqui a passagem problemática do produto artesanal ao produto industrial e, sobretudo, a necessidade e a condução de políticas públicas associadas a esses termos.

No plano internacional, as discussões das novas formas de produção estariam centradas nos desdobramentos do núcleo originário da Bauhaus nos Estados Unidos criando uma série de escolas de design e, na Alemanha, com a HfG de Ulm. ${ }^{133}$ Ambas as experiências seriam referenciadas no Brasil, primeiramente no Instituto de Arte Contemporânea do Museu de Arte de São Paulo, o IAC-MASP, cuja matriz seria New Bauhaus, mais tarde, Chicago Institute of Design, de László Moholy-Nagy e, pouco mais adiante, a Escola de Ulm seria referência para ESDI. ${ }^{134}$

Agora, com a próxima instalação do Instituto de Arte Contemporânea, estará o Museu em condições de enfrentar um dos problemas mais palpitantes da arte no mundo atual, qual seja colocar os modernos métodos de produção a serviço da divulgação em grande escala de objetos que representam a formação dos princípios da arte contemporânea. $\mathrm{Na}$ realidade, a industrialização constitui um aspecto essencial do problema. É verdadeiramente uma espécie de 'faca de dois gumes'. Desorientada artisticamente, torna-se perniciosa, difundindo o mau gosto, criando pelas suas incoerências, o caos. Compreendida não só como fator de conquistas materiais transitórias, ela pode servir ao desenvolvimento mental de um povo, tornar a vida moderna mais coerente, mais propicia à criação e menos 'mecanizada'. O objetivo do Instituto de

\begin{abstract}
Desenho industrial
Está se fazendo em são Paulo uma experiência de um certo interêsse para o assim chamado desenho industrial, têrmo aliás errado para a indicação do gôsto e da contemporaneidade da forma dos produtos manufaturados e fabricados em série. A experiência tem como centro o $\mathrm{Mu}$ seu de Arte, e mais especificamente o Instituto de Arte Contemporânea, escola experimental onde 25 alunos frequentam cursos de desenho, de estudo dos materiais, técnicos, a fim de formar uma mentalidade, ou melhor, uma paixão racionada para a forma. Êstes alunos, embora procedentes de escolas de arte ou arquitetura, recomeçam ex-novo, devem esquecer quanto aprenderam e considerá-lo como experiência negativa; isto porquê, na maioria dos casos o ensino teve seus epicentros nas imitaçōes de modelos antigos, no culto dos professores que desconhecem os novos mestres. Uma escola de desenho industrial que está em início, não pode prescindir da realidade do Bauhaus e do afamado Instituto de Chicago, para mencionar só dois fatores decisivos. Temos certeza do resultado dêste Instituto ser grande benefício numa cidade onde há viva ansiedade para iniciar um novo ciclo de história artistica.
\end{abstract}

IMG 62.

"Desenho Industrial".

[Habitat, n.2, p.94]

133 A Staatliches-Bauhaus funcionou entre 1919 e 1933, na Alemanha; Chicago Institute of Design, de 1939 a 1946, sob direção de Moholy Nagy e A Hochschule für Gestaltung Ulm foi fundada na Alemanha, em 1952, por Inge Aicher-Scholl, Otl Aicher e Max Bill, ex-aluno da Bauhaus, e durou até 1968.

134 Jacob Ruchti, "Instituto de Arte Contemporânea", Habitat n.3 (abril-junho de 1951): 62. 
Arte Contemporânea é justamente aclarar essa consciência, demonstrando em seus cursos que a máquina - considerada por muitos como escravizadora do homem - pode ser, hoje em dia, utilizada como elemento criador, e por isso mesmo de libertação. ${ }^{135}$

No horizonte da Bauhaus ao Institute of Design de Chicago estariam os métodos pedagógicos de Moholy-Nagy numa mirada produtivista ao mundo industrial, não sem conflito em sua utopia socializante a partir da reformulação do modus operandi mestre-aprendiz do mundo artesanal para o mundo industrial, na transposição do binômio mestre-da-forma e mestre-artesão, então equacionados na figura do designer moderno.

Hoy se ha erigido un nuevo Bauhaus en tierra americana. Los Estados Unidos son el principal baluarte de una nueva civilización cuya misión simultânea es la cultura e industrializacion de un continente. Es el suelo ideal para nutrir un principio educativo que pugna por lograr una más intima unión entre arte, ciencia y tecnologia. Para alcanzar este objetivo, uno de los problemas de la educación del Bauhaus es mantener incólume en los adultos la sinceridad emocional dei nino. La exactitud de su observación, su fantasia y su creatividad. Estos fines explican que el Bauhaus no utilice un sistema rígido de ensenanza. Maestros y estudiantes en estrecha colaboración, inevitablemente hallarán "nuevas maneras" de manejar los materiales, herramientas y las maquinarias necesarias para sus diseños. El espíritu de pionero que caracteriza al estudiante norteamericano es admirablemente apropiado para esta tarea. Temendo en cuenta nuestro nuevo ambiente cultural, y las dos décadas que han transcurrido desde la fundación del primitivo Bauhaus, el programa de la escuela en los Estados Unidos ha sido levemente modificado. Sin embargo, tanto

Finalidades do IAC no Museu de arte. Pretende colocar os modernos métodos de produção a serviço da arte contemporânea. Diário de São Paulo, 15/06/1950, reproduzido em Ethel Leon, Instituto de Arte contemporânea, Escola de Desenho Industrial do MASP (1951-1953)., op. cit., 74. 
en el nuevo Instituto como en el antiguo, el curso preliminar se considera parte fundamental del aprendizaje. En él pone a prueba el estudiante su capacidad y tiene su primer contacto con el tipo de trabajo que en el futuro constituirá su especialización. Las tendencias de su orientacion estetica y sus dotes creadoras seran encauzadas, abriendo se le un camino entre la multitud de "ismos" artisticos.

La preocupación intensiva y constante por los elementos de creación aguza su discriminación entre el diseno meramente diletante y superficial, por un lado, y el funcional "diseno orgânico" por el otro. Los ejercicios prácticos y el placer de las experiencias sensoriales le han de conducir a la seguridad de sensación, y luego a la creación de objetos que satisfarán las necesidades humanas, tanto espirituales como utilitárias. ${ }^{136}$

Primeira experiência moderna brasileira voltada para o contexto industrial, para Jacob Ruchti, designer suíço, fundandor do curso, ao lado dos Bardi, "O curso do IAC de São Paulo é uma adaptação às nossas condições e possibilidades do célebre curso do Institute of Design de Chicago, dirigido pelo arquiteto Serge Chermayett, e fundado em 1937 por Walter Gropius e Moholy-Nagy como uma continuação da famosa Bauhaus de Dessau". ${ }^{137}$

O Instituto de Arte Contemporânea é uma iniciativa do Museu de Arte de São Paulo. Tem por objetivo incrementar o estudo e as pesquisas no terreno das artes aplicadas. Adota uma orientação nitidamente contemporânea. Procura orientar a produção industrial, a fim de que seus objetivos, de uso comum e de alcance coletivo, atinjam um nível estético elevado e em coerência com a época atual. Assim, o Instituto está convencido de contribuir, através das artes aplicadas, para a formação de uma consciência clara da função social da arte. ${ }^{138}$

Dividido em três etapas de formação, passaria pelo curso preliminar, cursos especializados e cursos complementares, sendo o preliminar, próximo, tanto do Vorkus, na Bauhaus, quanto dos VkhUTEMAS, além da já mencionada referência do Institute of Design de Chicago e mesmo, da contracorrente racionalista representada pelo do styling. ${ }^{139}$ Destacaria, assim, o os trabalhos de Marcello Nizzoli, Giò Ponti, Ettore Sottsass, a dupla Eames-Raymond Loewy e George Nelson, entre outros, estendendo a lista dos mestres bauhausianos agora emigrados nas escolas de design americanas.

Junto à Jacob Ruchti, Lina apresentaria a aula inaugural, elaborando as bases do movimento que, no ano seguinte, seria a matriz da arte concreta no Brasil, pelo grupo Ruptura. ${ }^{140}$ Waldemar Cordeiro, Lothar Charoux, Geraldo de Barros, Kazmer Fejer, Leopold Haar, Luiz Sacilotto e Anatol Wladyslaw fariam parte do manifesto, cujas obras seriam exibidas no mesmo ano no Museu de Arte de São Paulo.

Como referência a este desdobramento, entretanto, não poderíamos deixar de enfatizar a presença de Max Bill que, desde 1951, se faz presente na instituição, primeiramente através da exposição retrospectiva de sua obra, além da própria repercussão do prêmio principal da I Bienal de São Paulo, direcionado à escultura "Unidade Tripartida". ${ }^{141}$ Sua vida efetiva ao Brasil ocorreria em 1953, e a controversa conferência realizada na FAUUSP em 9 de junho de 1953, seria publicada nas páginas de Habitat, denunciando o "espírito acadêmico modernizado" que regia a aplicação

\footnotetext{
136 Ver MOHOLY-NAGY, L. La Nueva Visión y Reseña de un artista. Ediciones Infinito. Buenos Aires, 1997 , p. 11 e12, prefácio de 1938.

137 Juliana Pereira. Desenho Industrial e Arquitetura no Ensino da FAU USP (19481968). Tese apresentada ao IAU-USP, 2009: 74-75.

138 Bardi, P. M. apud LEON. Ethel. IAC - Instituto de Arte Contemporânea escola de desenho industrial do MASP (1951-1953) - primeiros estudos. Dissertação de Mestrado apresentada a FAUUSP, 2006.

139 Juliana Pereira. Desenho Industrial e Arquitetura no Ensino da FAU USP (1948-1968). Tese apresentada ao IAU-USP, $2009: 75$.

140 Aracy Amaral, Arte Construtiva no Brasil, op. cit., p.232.

141 A revista Habitat faria duras críticas ao projeto da Primeira Bienal de Arte que, longe de possuir um projeto próprio, em termos de representação e critério de exposição, referia-se ao modelo de Veneza como fenômeno comercial. Ver. Alencastro, "Veneza", Habitat n.2, op. cit.: 96; Alencastro, "Organizar", Habitat n.10, op. cit.: 94 e "Exposicao de arquitetura: proposta", Habitat n.4, op. cit.: 78.
} 


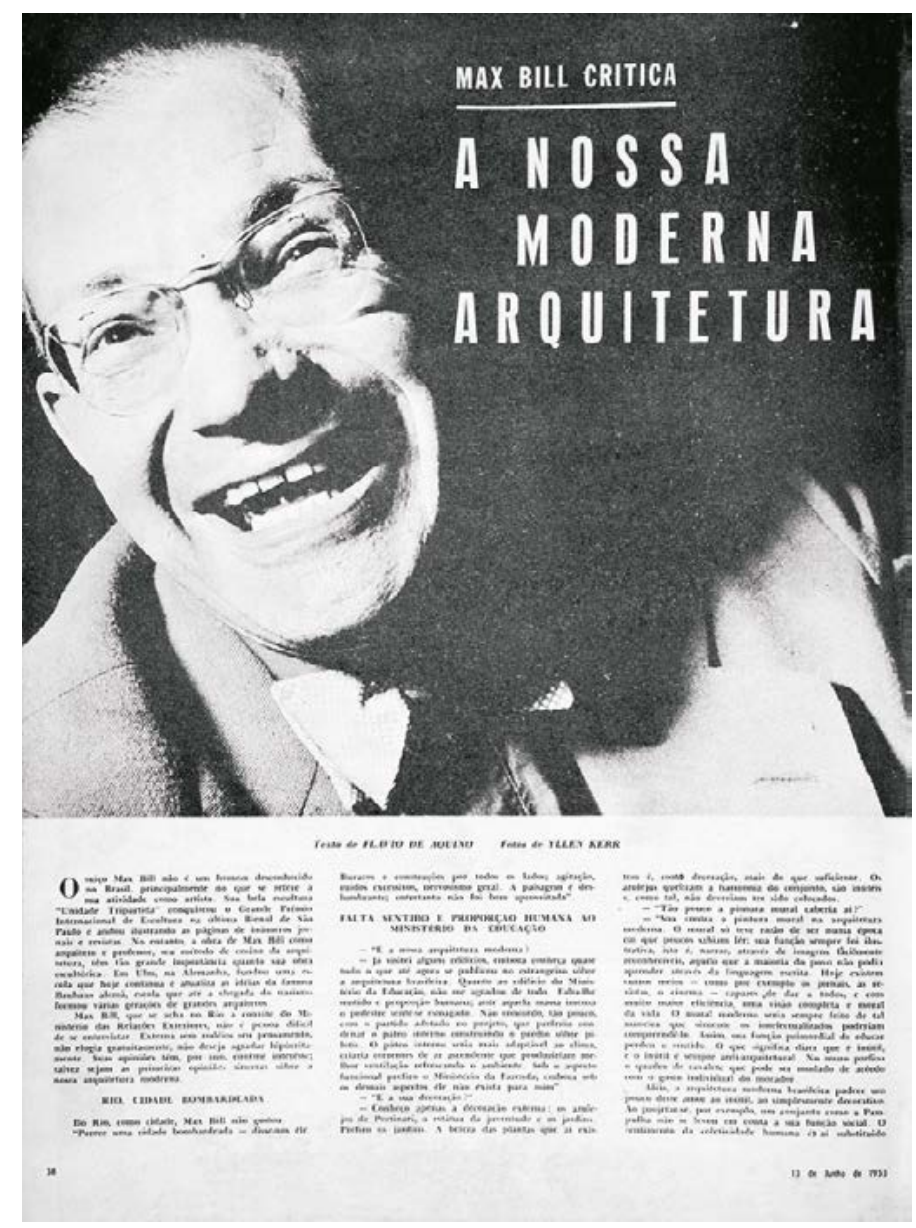

IMG 63.

Max Bill.

[Habitat n.12, p.38]

IMG 64.

"Unidade Tripartida". [Coleção MAC-USP]

descompromissada dos cinco pontos de Le Corbusier, em solo tropical. ${ }^{142}$ "Ficaria desgostoso comigo mesmo se não afirmasse que a arquitetura brasileira corre o risco de cair num perigoso academicismo anti-social" ${ }^{143}$ relataria diante das formas, antes, derivadas da "expressão individual e não ao seu caráter social dado pela atenção a funcionalidade do edifício e seus componentes". ${ }^{144}$ Visão próxima apresentaria Gropius, no ano seguinte, que em vista a Casa das Canoas, diria: muito bonita, mas não multiplicável". ${ }^{145}$

142 Flávio d’Aquino, "Max Bill, ou iconoclasta inteligente", Habitat n.12, op. cit. : 34

143 BILL, Max. "O arquiteto, a arquitetura e a sociedade", em XAVIER, A. Depoimento de uma geração. São Paulo: Cosac Naify, 2003.

144 Ibidem.

145 Cf. Depoimento de Oscar Niemeyer. In: Wisnik, Guilherme (org.). O Risco, Lucio Costa e a utopia moderna.

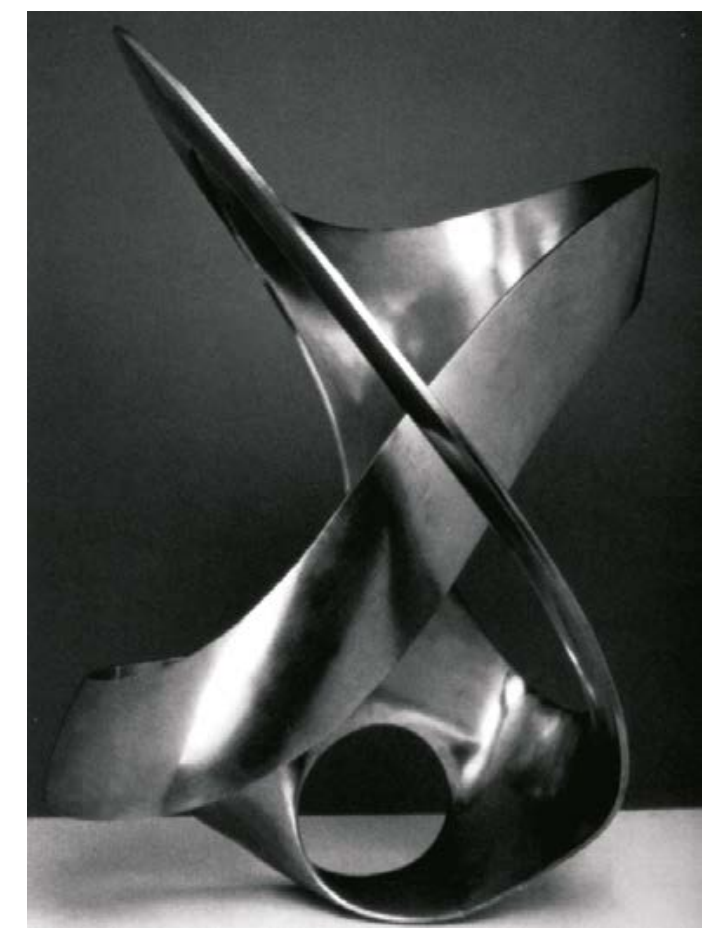




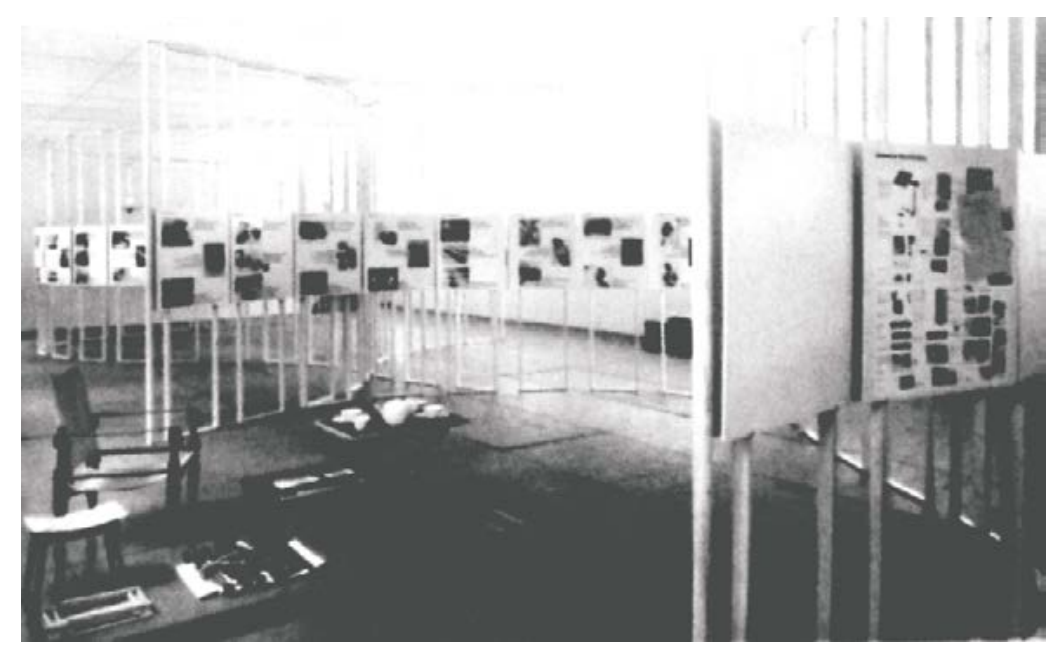

IMG 65.

Exposição Max Bill em Basel. [NOBRE, 2009:Anexo]

Da "oportunidade perdida" declarada por Lúcio Costa, ${ }^{146}$ a revista Habitat veria a possibilidade fomentar o debate acerca da jovem arquitetura brasileira, "talvez (...) as primeiras opiniões sinceras", ${ }^{147}$ para quem a "bela criança" precisaria de instituições fortes pautadas em uma crítica especializada. Esse treino intelectual em respostas às análises menos personalistas e, por vezes provocativas, seria, na visão de Lina, a ponta de lança da autocrítica que Oscar Niemeyer faria no depoimento de 1958. ${ }^{148}$

Além dessa teoria, havia a outra, a do caldo de feijão: crianças no Brasil são alimentadas com caldo de feijão, que contém ferro, importante na absorção dos demais alimentos. Parecem viçosas e fortes, a fome vem logo em seguida. Ela se referia a jovens músicos, poetas, artistas em geral, autores de uma brilhante obra, na estreia, e que depois somem, não continuam a carreira inicialmente promissora. ${ }^{149}$ [SUZUKI, 288]

146 Lúcio Costa, "Oportunidade perdida ", Manchete n.63 (4 de julho de 1953), reproduzido em Lúcio Costa: sôbre arquitetura, Alberto Xavier (org.) Porto Alegre: Uniritter, 2007, 252-259.

147 Flávio d'Aquino, "Max Bill, ou iconoclasta inteligente", Habitat n.12, op. cit. : 34

148 "Depoimento", Módulo, n. 9 (fevereiro de 1958): 3-6.

149 SUZUKI, Marcelo. Lina e Lucio. Tese de Doutorado. IAU-USP, 2010, p.288. 


\section{Duas Grandes Exposiçôes no Museu de Arte $_{\text {nte }}$}

\section{Cassio M'boy, o pintor do nosso folclore, e Max Bill, o revolucionario das linhas e das formas -} Lina Bo fala sobre o arquiteto suiço

Duas exposicōes assinalam, no Museu de Arte, o ponto atto do movimento artistico da semana. Uma é a do conhecido pintor Cassio M'Boy e outra a do arquiteto e pintor suigo
Max Bill.

Cassio M'Boy, cujo verdadeiro nome é Cassio da Rocha Matos nasceu e se crion numa fazenda de café do interior do Estado, Descende de antigas familias paulistas, originarias dos primeiros colonizadores que aportaram em Sâo Vícente. Viveu alguns anos em São Pauto. Em 1920 foi residir na Viia de M'boy, hoje Embu, procurando assimilar os costumes tradicionais da zona. Poucos anos depois confundiam-no con os descendentes dos catecumenos do padre Belchior de Pontes, fundador da localidade. $E$, pintor a tambem eseultor. Nâo teve mestres, trouxe do berco sua vocació artistica. Conquistou medalha de ouro na Exposiçáo Internacional de Paris, em 1937, tendo concorrido com uma "Fugga para o Egito", esculpida em madeira, modalidade de arte à qual se dedicon durante muitos anos, tendo canalizado quase a totalidade ie sya productio para o estrangeiro. Cassio mrboy e um grande interprete das lendas como sâo conhecidas naquela regiāo.

Nessa sua exposicin no Musen de Arte destacam-se os quadros: "Mhe do Ouro" "o Diabo de M'boy", "Máe da Agua", "Saci" - "Nossa Senhora do Desterro". Max Bill naseeu em Winterthour, na Suica, em 1908. Estudou no Bauhaus de Dessau, Trabalha atualmente por conta propria em Zurique. dá projeton publicos, exposicós, planos de urbanisino. Tem sind $\mathrm{em}$ set attivo inumeras ohras do escultu$r a$, arquitetura, ensalos, artigos dédicados 20 problemas de arquitetura, escuitura e pintura. Sobre 2 importancia da exposiçáo de Max Bill ouvimos opiniáa da arquiteta Lina Bo. - "Bill pertence aqueia categoria de artistas contempora (especialmente arquitetos), cuifo inserimento para as solucóes faceis do nüo controlado, do náo exato, é absoluto. A matematica esta na base de toda a sua concepcĭo, nâo a matematica imaginada pelos teigos, isto é "fria", mas a matematica camo pode ser hoje considerada intespral.

"Admirando as pinturas 0 as esculturas, as arquiteturas e as composiçóes graficas de Max Bii., um amigo inteligente, dedicado aos problemas da arte moderna, observava suas pinturas "conferirem" nas provas, como as operacoes simpies," "peracualque sempre "concluem", de qual-

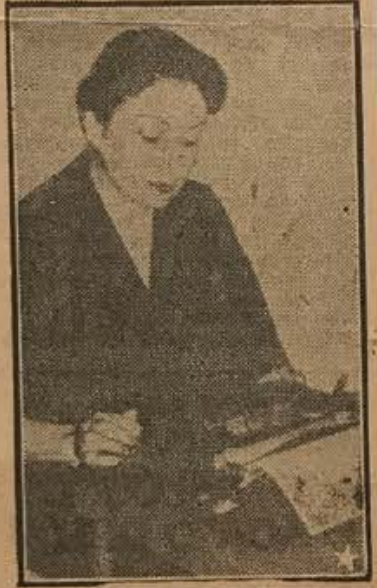

Lina Bo Bardi

- contínuado acerca da imporconcia do ne.0 compromisso nm tamanha acusacío à leviandade que o observador acaba percebendo sua mensagem; é o que parecia a primeira vista jogas abstratos de formas, assume agox2 un aspecto deriniaso e concreLo, torna-se proiccia de um tempo novo, capaz de se manifesta: consciencla matematica, naquele

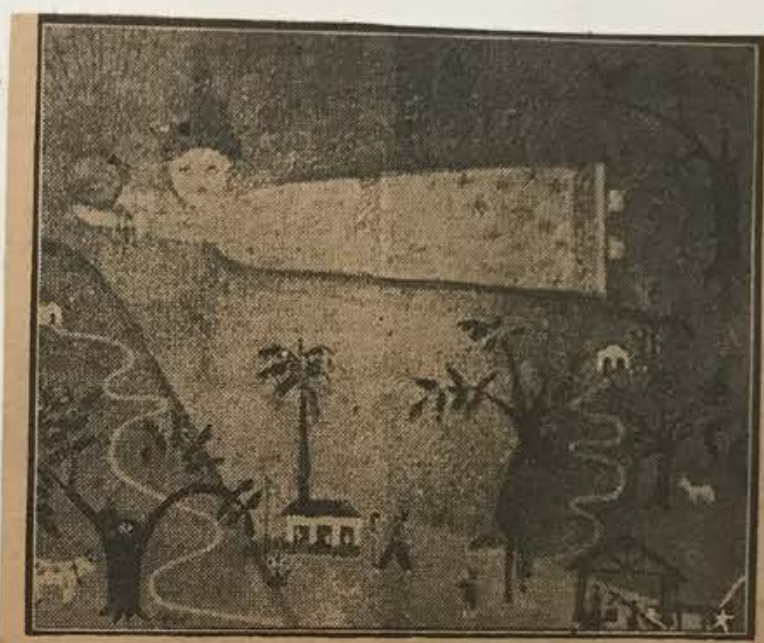

MAE DO OURO T̄ Reside no Morro do Jaraguá. los morros circunvizinhos, preferindo sempre os mais elevados, nunca visitando dois ou meis morros por passelo: visita cade um por sua vez. Em Embu é vista vindo do Jaraguá para o morro Votorantim, que é o mais alto daquela regiéo, e deste voltando para a sua morada, que é o Jaragutâ. A Mãe do Ouro é uma litalsstma muther, muito branca, com os cabelos cor đe ouro, que passa rapidamente pelo céu, veste-se com tecidos flamejantes, bordados a ouro, com incrustacōes de pedras preclosas; enfeita-se dos pés à cabeca com adornos riguissimos de ouro. Em hipotese alguma separa-se de uma rande perita de ouro que rutila em suas mốos ao nonto die ofuscar iz vista humana. A Mäe do Ouro é "encantada". existe umi a vista capaz de a "desencantar". mas ninguem sabe quat solavie sendo, quando ela passa, as pessolas grila eson das as palavras que thes ocorre pon no hessuas gritam to"palavras feias", pois que aguele gue consegu, "cese senao

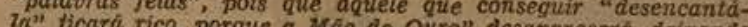
cair a pedra de ouro a inte do oiro cair a pedra de ouro e todas as suas jótas. Ela é intojenstva, mas mesmo assim é temida.

frontava-as as composiçōes musicais dos mestres primitivos. Entretanto, ha outro aspecto
nas obras de Max Bill, naguelas guas telas que parecem "caueins dos sisudos, naquelas suas ar quiteturas extremamento contro. ladas o propositalmente năo oripinals, nilo tortuosas, nío visto-
sas, mas que maraviliam, ao sas, mas que maravilham, ao contrario, o observador cuidadoabsoluta das soluçōes. Em todas estas obras há uma intransigen- anselo determinante de nilo dies.

"Sta estes os valores concretos da arte de Max Bill, e é natura ćto conciliante, facil a geraquer encarar problemias: 6 natural que a sua arte desagrade tambena aos fautores da velha cuitura, para os guais ela reuYar nil acusaráo. imi os fatos: de una ger expilat assistiu - a catastrofe da guerre que i. rateneta da fuirura trasicio nal, Coma pesquisador cuidadoso e solltario de novas possibi.-
lidades, Minx Bill, todavia, nío

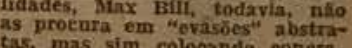
tamente os problemas, parece-
nos ouvir a esta altura a voz de
uma senhora, ene dilientemenuma senhora, que dilisentemen-
te frequenta as expostcos, perEuntando:

possivel "Mas, meu Deris, como of possivel chamair de pintura aque. um funde completnmento poise $\cos -c$ onde estalo os famer. problemas da arte?" os problemas da arto nise existom, pols os probleman ê. tem passin eat at transeen problemis univa o campo do. Tax Bili, 6 mister fo, b antes do mals nosquecearquiteta $a^{\mathrm{e}}$ - concilufu a sma na Bo. 
Se revista já apontava essa direção em sua linha editorial, antevendo "muitos sinais alarmantes de que o 'moderno' acaba sendo um treino gráfico, a preguiça, a piada", ${ }^{150}$ Lina não deixaria de reconhecer o entusiasmo da jovem arquitetura. Em suas palavras:

A mesma febre de fazer, e de fazer rapidamente, está presente na arquitetura brasilei$\mathrm{ra}$, que tem somente pouco mais de 10 anos de vida. $O$ arquiteto brasileiro é um rapaz chamado à luta subitamente e que lançou-se com coragem e generosidade, sem conhecer a fundo o "mecanismo". O seu ímpeto comove. Finda a batalha, coloca-se a questão de decidir se $o$ arquiteto merece ou não a medalha. É preciso isolar desse conjunto que desconcerta e enerva o europeu, os elementos positivos dessa arquitetura, os elementos "autênticos", que não dependem da limitação de cultura: soluções construtivas extremamente simples e frescas, uma modéstia aliada a um sentido festivo da vida: os arquitetos brasileiros foram os primeiros a colocar cor em sua própria arquitetura. Na aurora de suas possibilidades, no entusiasmo de suas realizações, o arquiteto brasileiro pensou que "tudo era permitido", que não havia necessidade de "revisão". Esta disposição psicológica somente agora está sendo mudada. Os jovens que saem da universidade estão voltados para esta revisão: a nova arquitetura brasileira poderia começar agora. ${ }^{151}$.

Na mirada em direção à indústria, o mesmo entusiasmo com a democracia americana a favor do design moderno que, ao final da Segunda Guerra, Lina, Zevi e Pagani editaram a Revista $A$, o IAC procurava dirimir as distâncias de São Paulo aos centros produtores de conhecimento na produção técnica direcionado ao mundo industrial.

Entretanto, as referências de ensino de design referidos se mostrariam insuficientes

\footnotetext{
150 "Construir com simplicidade", Habitat, n.9. op.cit.

151 Lina Bo Bardi, "Lettera dal Brasile", escrito em 1956 para

a revista romana L'architecttur, em FERRAZ, op. cit., p. 95.
}

IMG 66.

Exposição Max Bill.

[Diários de S.Paulo] 


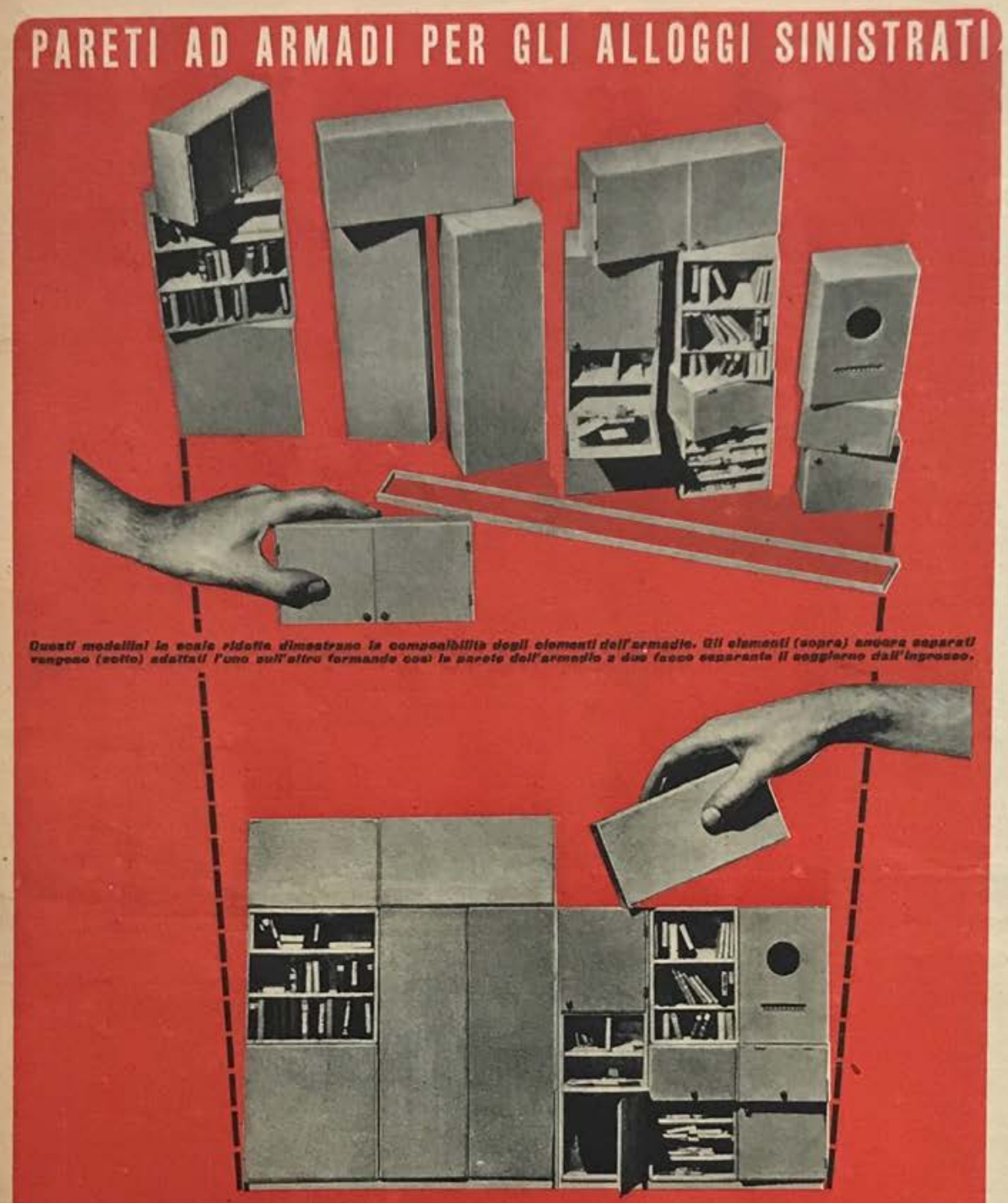

VERSO IL SOQGIOANO

Questó tipo di armadio permette di drut rione in un comuse allozicia. Infatti der vortituite dalla parete armadio la quale scuno dei due ambienti af duc lati dell' a chia tramema demolita ens di $10.14 \mathrm{~cm}$. $\mathrm{cm}$. Iingombiro mazziore de di woll s.10eliminare gran parte dei comuni moblli madio. Le armadiate risultano compreste larghi in media da 50 a $60 \mathrm{~cm}$, che si pe elementi-per particolari uxi poswono magk si ottiene anche una magziore varieli di tarsi con un minimo scarto alle lunghea senta il lato venio il soggiomo della part Tingress, Libri, dischi, cancellenia e cart un servizio per vino; ecto aleuni degli of delia stanza di soggiomo. Scaffali apert portata dei bambini. Uso scrittoio a nibol vere; $d$ sormontato da cascetti e da th 5 . chi scrive seluto, Una combinarione di 6 mofono ad un'alterza ngionevole per Yuxe cente all'a pparecchia, Venso if sogriarno
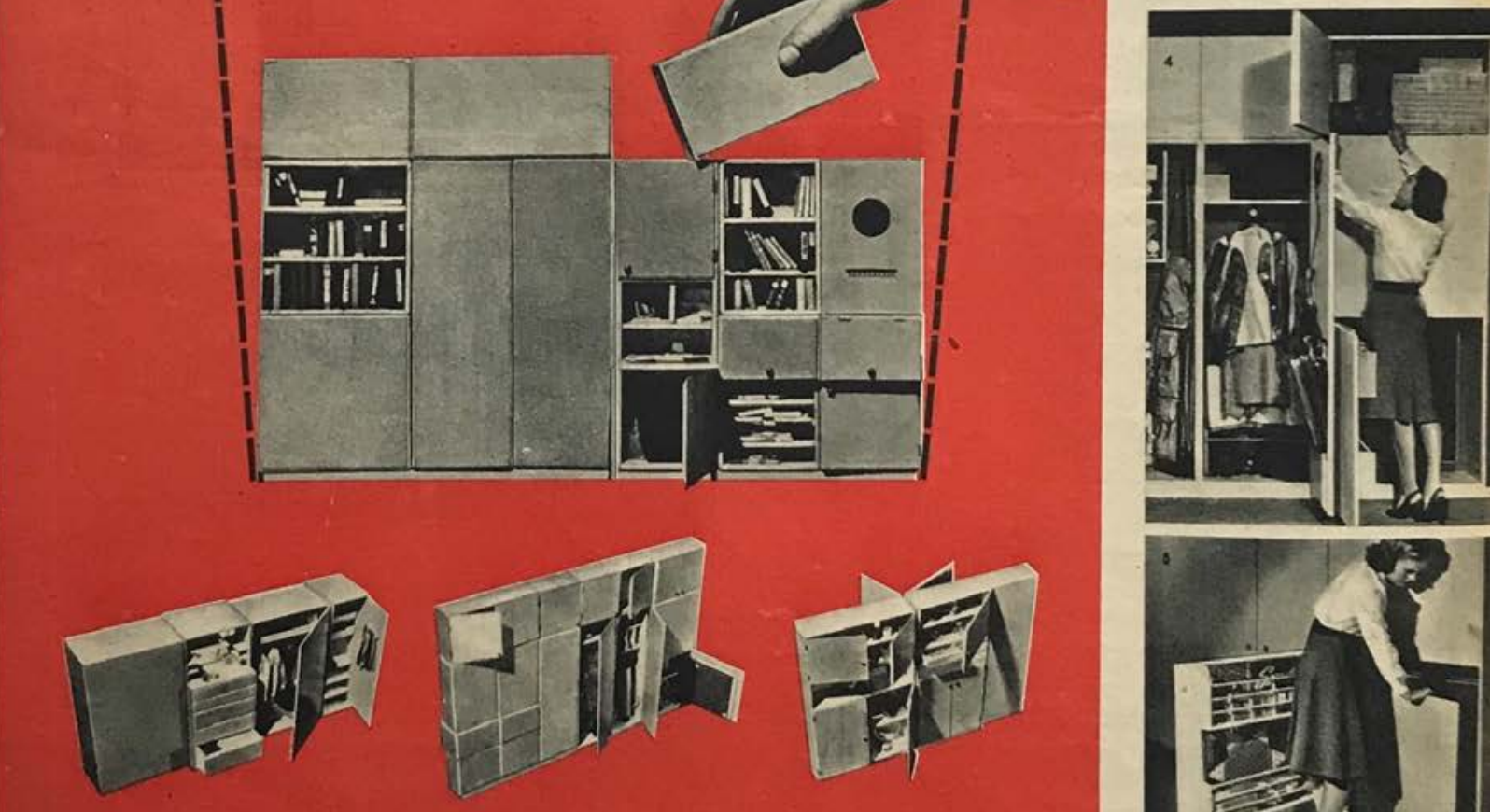

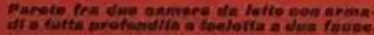

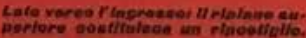

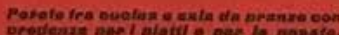

Molif lottori ci hatuo chieato maggiori informazioni sulle pareti arma. di viota escluaivamente economico. Inoltro 1 vantaggi che si ottengono diato di cui abbiamo pubblicato una fotografia nul n. 1 di " $\boldsymbol{K}$ ". Li sono considerevoli: risparmilo di spaxio, massima abitabilith degl aocontentiamo in questo numero aggiungendo alla documentazione ambienti. Anche lo porto di passaggio possono venire incorporate dellopera degll architotti G. Noleon o H. Wright una proposta del. in queste pareti senza alterame la compattezza. Praticamente if tip Tarchitotio Baldo Bandini nguardante 1'spplicaxione delle pareti arma- ai possono ridurre a tre: olement por pareti tra cucina o rtanza d diato a veochi odifici, propouta particolarmente vantaggiosa nel caso pranzo (con ante e cassottl apribill dai due lati); elomenti per parot

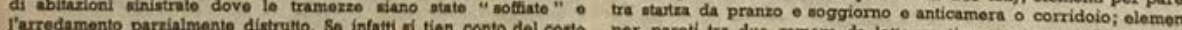
della ricostruzione di un muricelo a dol mobili cho vangono costo per pareti tra due camore da letto contiguo, o tra ura di queato

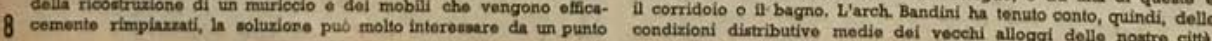
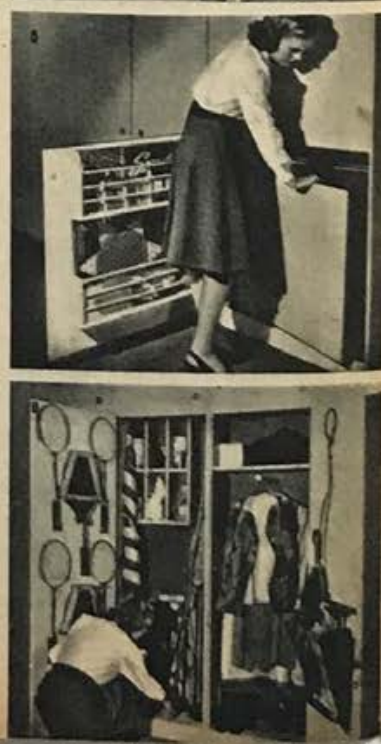

IMG 67. 

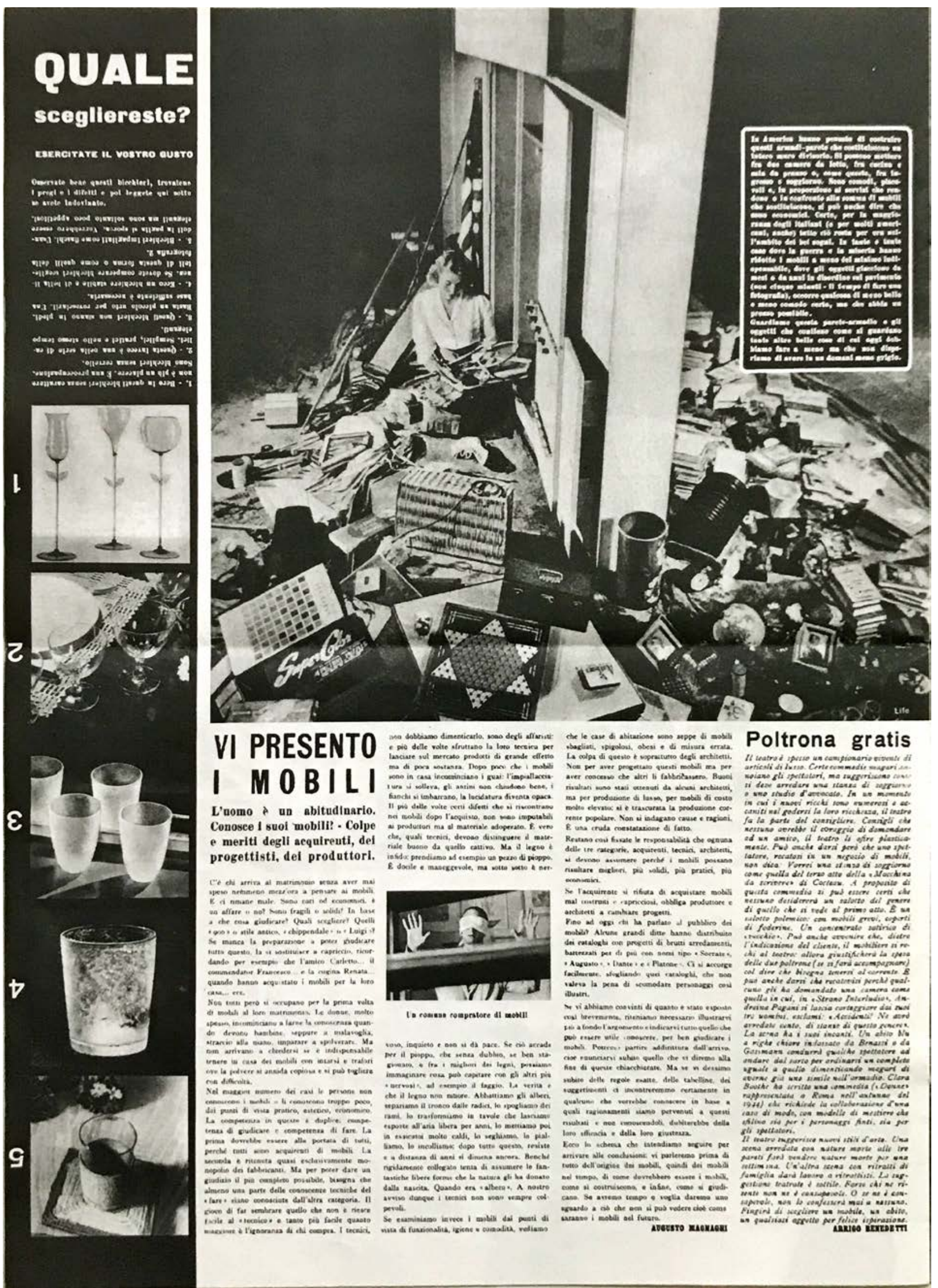

VI PRESENTO I MOB I L I

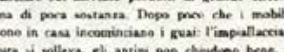

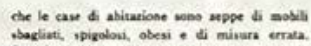

Poltrona gratis

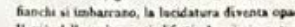

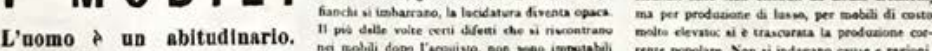

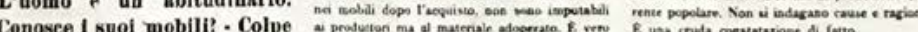

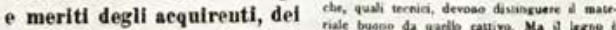

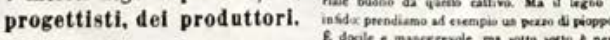

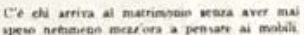

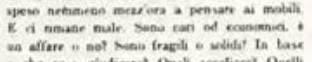

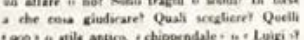

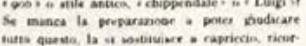

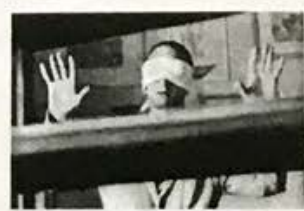

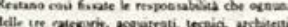

it do

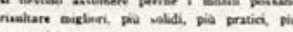

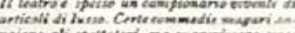

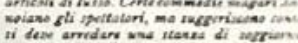

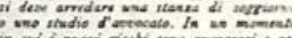

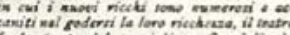

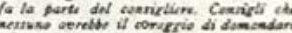

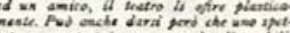

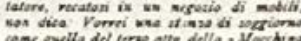

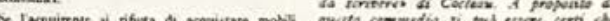

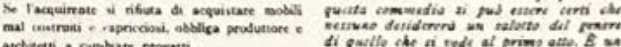

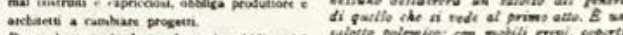

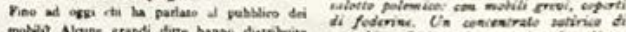

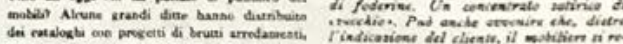

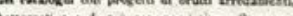

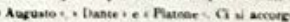

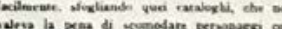

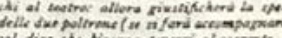

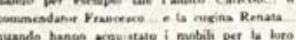

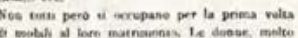

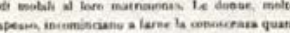

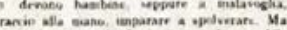

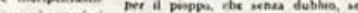

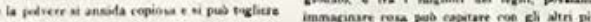

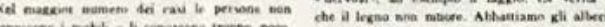

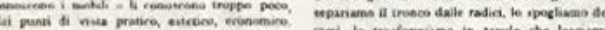

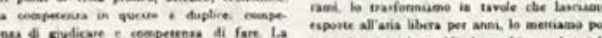

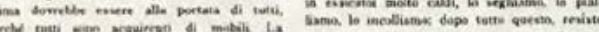

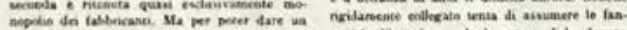

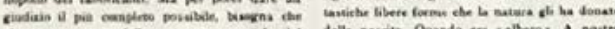

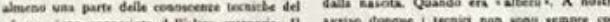

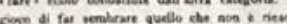

triok

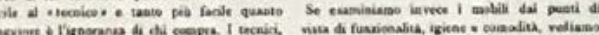

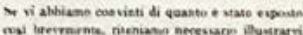

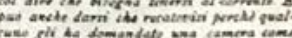

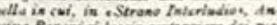

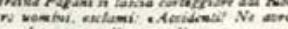

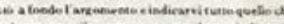

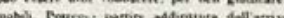

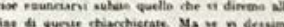

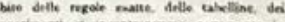

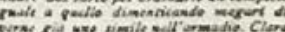

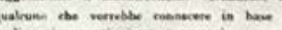

(a)

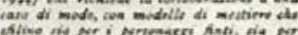

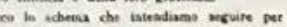

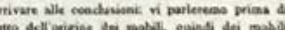

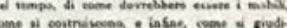

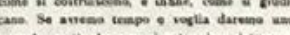

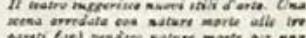

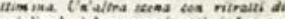

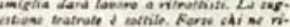

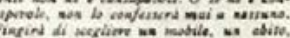

aversro navies

intoo intortm 

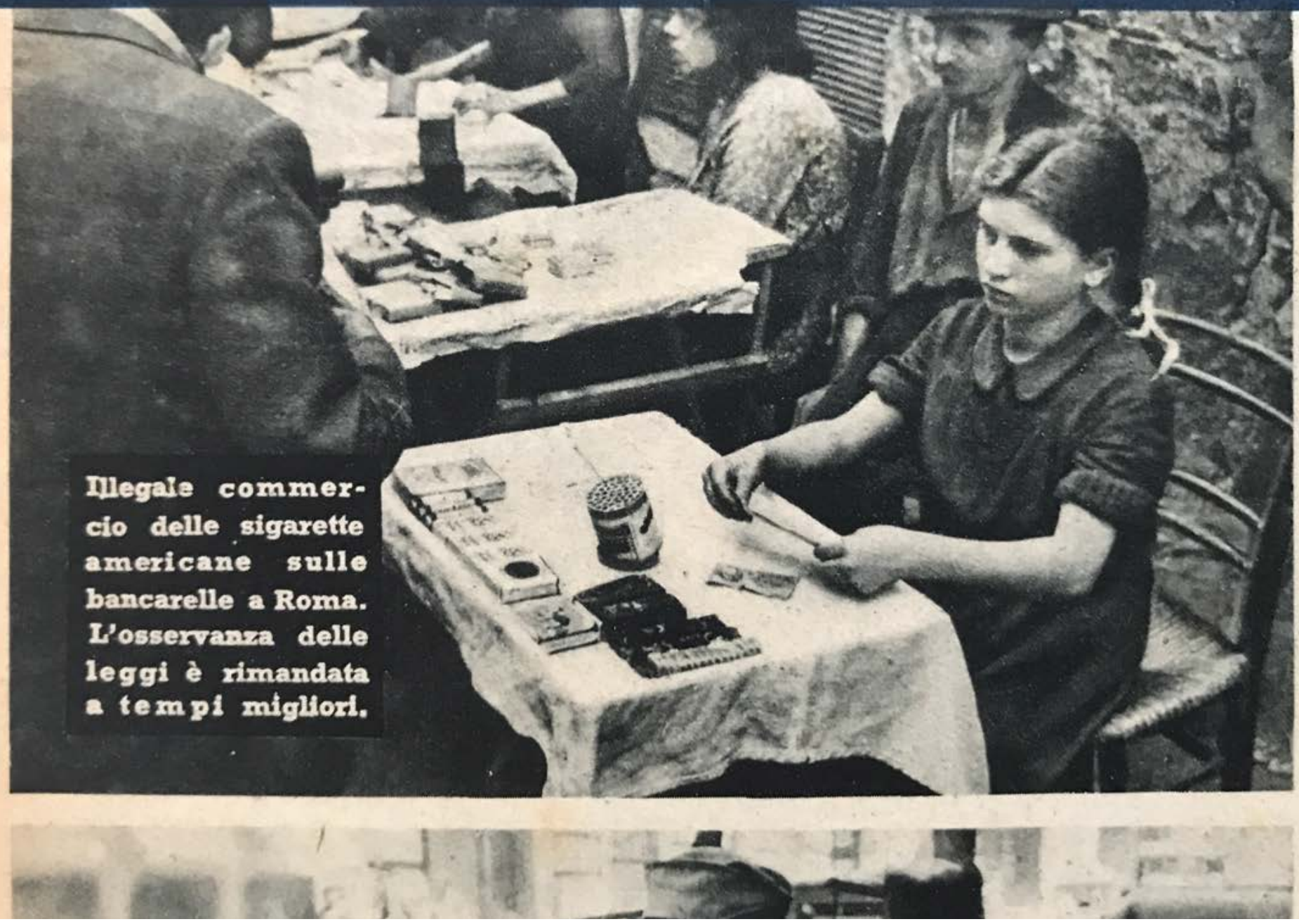

IMG 69.

Industria americana. [Revista A, 1946] para abarcar os paradoxos existentes em nosso processo econômico e dinamizar em progresso a rudimentar estrutura social existente, em que a relação entre trabalho técnico-artístico e indústria não se configurou no horizonte de uma emancipação cultural, ao exemplo dos Estados Unidos que, desde o século XIX, avançou sobre a escala americana constituindo uma indústria responsável pelo sucesso da ocupação e, mais tarde, pela cultura material reprodutível em massa.
O entusiasmo nascente com a autonomia cultural norte-americana equacionada como modelo institucional seria, paulatinamente, revisionada na imagem de uma América que "esvaziou Gropius e Mies van der Rohe, acabou com a inventiva de Grosz e a violência de Kurt Weill - que se tornou compositor de adocicadas melodias de filmes" ${ }^{152}$ crítica presente nos textos de Argan, ao denunciar a subversão contida na apropriação da utopia socialista do design ao sistema capitalista. ${ }^{153}$

152 Lina Bo Bardi. "Na América do Sul: após Le Corbusier, o que está acontecendo?". Mirante das Artes, n.1, jan-fev. 1967, pp.10-11.

153 Ver prefácio para o livro de Tomas Maldonado, El Diseño Industrial Reconsiderado e "A crise do design", em História da Arte como História da Cidade, pp.251-267. 
Com a desenvoltura de quem é rico, bonito e bem-educado, o sr. Ray Smith, associate editor (Feature and Interior Design) da importante revista de arquitetura norte-americana Progressive Architecture, apresenta um panorama da arquitetura da América do Sul [...]. [Ele] aconselha paternalisticamente os arquitetos sul-americanos a não copiar a arquitetura "internacional industrializada" dos países desenvolvidos, mas a se inspirar nas ocas dos índios, nos "ranchitos" e nas "favelas" dos pobres, como convém a arquitetos subdesenvolvidos [...]. Baseado num equívoco (não queríamos pensar em má-fé) o autor [...] expõe explicitamente a convicção de que a verdadeira arquitetura é norte-americana, baseada na produção industrial de massa, à qual os jovens arquitetos latino-americanos "ainda" não podem ter acesso, por causa do subdesenvolvimento do país e deles mesmos. ${ }^{154}$

Evidentemente, o pós-guerra também apontava para um colapso nas formas das instituições, exigindo o enfretamento dos desafios colocados pela cultura de massas, que logo também esbarrariam com as limitações de um sistema pedagógico referenciado em modelos utópicos, cujo gute Form, constitutivo do standard, seria então perspectivado com obsolescência programada decorrente do avanço da cultura industrial em sua lógica exacerbada de consumo. No limite, esbarrariam com a crise dos parâmetros socioculturais que organizavam o mundo ocidental, cujo marco seria as manifestações de maio de 1968.

Não só o curso do IAC, mas a agenda pedagógica do MASP como um todo, desde as conferências abertas ao público, ${ }^{155}$ a horizontalidade das exposições didáticas e na vitrine das formas, que agiam sobre o gosto moderno na concretude da historicidade necessária para o redimensionamento dos valores escolhidos como válidos, passando pela Habitat que tão bem se utilizou do "mas media" não como "acontecimento da natureza", ${ }^{156}$ mas como uma construção desejada, Lina sinalizaria a necessidade de um campo institucional para a produção industrial no Brasil no horizonte de uma civilização técnica.

A construção de uma autonomia no design passa necessariamente pelo IAC, cuja breve existência, no início da década de 1950 , não só formalizou a discussão dentro de um campo profissional, como promoveu um diálogo que se desdobraria em outras instituições. No Rio, a Escola Técnica de Criação no MAM-RJ e a ESDI, pelo então Estado da Guanabara, em 1963; ${ }^{157}$ e em São Paulo, em 1962, a Sequência de Desenho Industrial da FAU-USP, a partir da revisão de ensino proposta por Vilanova Artigas, ${ }^{158}$ além do início do Instituto Superior de Desenho Industrial, coordenado por Mário Pedrosa, ligado à Universidade de Brasília, no início dos anos 1960.

Passados três anos de funcionamento, o IAC encerraria suas atividades, cuja descontinuidade foi atribuída tanto ao financiamento insuficiente para sua operação, que amparados fundamentalmente pelo grupo Diários Associados dependiam de uma aproximação dos industriais paulistas. Além formação necessária vinda da aproximação direta nos processos e materiais industriais - saindo da estrutura artesanal de suas instalações, $o$ apoio imaginado se daria na troca pela qualificação profissional desejada de mão-de-obra, interesse este não concretizado pela classe industrial, já habituada a reproduzir modelos projetados no exterior como referência de produção e consumo.

No descompasso entre o refinamento da produção de objetos de consumo pela IAC à inexistência de uma indústria capaz de absorver as demandas do mobiliário moderno idealizado pelo Studio Palma, somava-se à crise institucional do MASP enquanto

154 Lina Bo Bardi. "Na América do Sul: após Le Corbusier, o que está acontecendo?". op.cit.

155 Passaram pelo auditório do Museu, Oscar Niemeyer (em 1948), Henrique Mindlin (1948), Rino Levi (1949), Alvar Aalto (1954), Sergio Millet (1948 e 1949), Washington Luís (1948), Gilberto Freyre (1948), Manuel Bandeira (1947), Camargo Guarnieri (1947), Alberto Cavalcanti (1949 e 1952), Germain Bazin (1948 e 1951). In: Pietro Maria Bardi. Revista Museum, op.cit.

156 Lina Bo Bardi. "Na América do Sul: após Le Corbusier, o que está acontecendo?".op.cit.

157 Ver NOBRE, Ana Luiza. Fios Cortantes. Projeto, produto, arquitetura e design no Rio de Janeiro. Tese de Doutorado apresentada a PUC-Rio, 2009:67-70.

158 Vilanova Artigas, "Introdução", em Marcelo Carvalho Ferraz (coord.) João Vilanova Artigas. São Paulo: Instituto Lina Bo e PM Bardi, 1997, 28. 
utopia socializante pautada em uma agenda pedagógica incapaz de promover a democratização no país. "O público estava ausente", ${ }^{159}$ referia-se Habitat, ciente do círculo que se retroalimentava na elite paulistana.

Frente aos problemas colocados sobre o sistema de produção e consumo e suas amarras econômicas inerentes ao sistema capitalista, somada às contradições que a instabilidade social no país impuseram na passagem da produção manufatureira para a industrial, que necessariamente atravessava as relações de trabalho, a mirada de Lina para o Nordeste brasileiro antevê uma potência possível neste "outro" - produtor de sua própria vida material. Longe de se configurar como um sistema autônomo essa "força latente" não consolidada em políticas públicas e formalizada em linguagem industrial, mais tarde, se consolidaria como a dura afirmação do status quo enquanto resíduos da sociedade de massas, cuja "inventividade" por si só jamais se consolidaria em um caminho possível e desejável.

O Brasil é um país fundamentalmente agrícola, a estrutura do país é agrícola. Isso não quer dizer que se deva ficar assim na base do sonho reacionário de volta ao artesanato, de jeito nenhum! Mas a dosagem, o verdadeiro estudo, o verdadeiro planejamento, com as verdadeiras bases econômicas sociais de estudo por estado do país, nunca foi feito, não existe um plano nacional. ${ }^{160}$

Em termos marxistas, Lina diria que pensar a industrialização como "pulo para o socialismo" na formação das classes operárias seria um erro. "No Brasil não existe burguesia, existe apenas uma classe média, pois a revolução burguesa não conseguiu se efetivar no Brasil. [...] aquilo que existe é uma classe média, assim chamada produtora e que não produz nada. Enquanto a burguesia estava tendo um papel importante na Europa, o Brasil não tinha possibilidade de se projetar pois era um país ainda ligado a valores coloniais." 161

159 "Lições de arte para 20.000", Habitat n.7: xxx

160 MENEZES, Aureliana. Entrevista com a arquiteta Lina Bo Bardi. FAU-USP, 20 de agosto de 1976. Arquivo ILPMB.

161 MENEZES, Aureliana. Entrevista com a arquiteta Lina Bo Bardi. FAU-USP, 20 de agosto de 1976. Arquivo ILPMB. 
construtiva da história da arte. Estando a arte tão intimamente ligada à vida, a ponto de tornar-se uma de suas formas, tornar-se uma de suas formas, como poderiamos prescindir de um seu curso completo de es tudos? Estudam-se história, filosofia, literatura comparada e tôdas as outras ciências e dis ciplinas que servem para en quadrar o homem em suas épocas, em seus ambientes e em suas realizacôes. Ora, porque ñio reunir tôdas estas partes do náo reunir todas estas partes do superbo arte?
da aresco sobre o fund

Digamos mais: já que a arte permanece com seus movimen tos, mais evidente menos hipotética do que os documentos em gera!. afirmemos, por exemplo. que a história da península ibérica, da Sicília, por assim dizer, das comunas italianas ou das cidades hanseáticas, estuda-se melhor - ou, cas, estuda-se melhor pelo menos, compreende-se melhor, integrando os estudos dos documentos escritos com os dos documentos edificados, esculpidos, pintados.

Concluamos: o estudo da história da arte nảo é um luxo nem uma perca de tempo. Tampouco é um pêso para os estudantes já oprimidos por programas densos. Ao contrário: é um ugradável, por natureza, pois agradavel, por natureza, pois esta "aseada na "epresentação e no "espetaculo" do belo; integra e completa o estudo das outras historias, politica, filosófica e literária e torna êste estudo fácil e mnemónico com as referências as obras e monumentos característicos. Poder-se-á compreender. por exemplo, e será mais fácil de ser lembrada a gigantesca corrida dos muçulmanos da Méca rida dos muçulmanocermos e tivermos a agradável lembrança vermos a agradavel lembrança dos monumentos mouriscos que
assinalaram - e ainda assinalam - suas etapas.

Êstes conceitos estão presentes no espírito da direçăo do "Museu de Arte" que, como várias vêzes foi dito, não constitue apenas uma "coleçẫo" ou uma "penas " e sim deseja ser, an"galeria", e sim des uma "escotes de mais nada, uma "esco-
la". Além das preciosas obras la". Além das preciosas obras
que posue, sua maior riqueza, em sentido potencial, é sua galeria didática, seu setor pedagógico que deve precisamente servir a tornar acessiveis compreensiveis a um público sempre maior. sempre maior, os tesour se văo ordenando nas outras
salas do Museu.

\section{Teatro}

E' necessário construir um teatro de prosa permanente; mas antes disto é necessário criar antes disto e necessario criar uma escola de arte dramatica espectador notando a maneira espectador notando a maneira de gesticular de uma de nossas artistas. E acrescentava: Um diretor verdadeiro conse-
guiria tirar o cinquenta por cento de seus defeitos.

\section{Ipiranga}

Lemos nos jornais paulistanos: "A visita publica ao Museu Paulista foi, no mês de julho próximo findo, de 42.590 pessoas. Em julho do ano anterior fôra de 33.174 . A afluéncia maior verificou-se aos domingos, especialmente a 15 e 22 de julho, quando o total de 22 de julho, quando o total de
visitantes foi respectivamente visitantes foi respectivamente
de 7.590 e 7.636 pessoas. Durante os dias úteis a maior afluência registrou-se dia 12, quando procuraram o Museu 1.481 pessoas". Parece que vamos para a frente com os museus.

\section{$5.000 .000,00$}

O "Palmeiras" ganhou o campeonato nảo sabemos do que, um campeonato mundial, e dai grandes festejos. O Estado conferiu ao "Palmeiras" cinco milhôes de cruzeiros. Muito bem: os músculos dos atletas terão os musculos dos atletas terão novo alento e a energia dêstes
musculos produzida por tanmusculos produzida por tan-
tos cruzeiros permitirá que novas vitórias favoreçam êste "team" simpático. Ótimo, também para aquela massa de pobrezinhos que se empilham aos domingos nos estádios, afim de torer para um ou outro do torcer para um ou outro dos outro dos jogadores que sabe melhor chutar. A "mens sana" destas multidoes juntamente com o "corpore sano" dos vários "Onze", será, sem dúvida alguma, um belo futuro e nós somos velhos demais para assistir a um futuro em que a honra das naçōes será entregue aos jogadc aos jogadores de futebol. Ja temos o futebol nas ruas, nas paginas dos jornais,no ar, na televisäo, por todo lado. E se continuarmos dêste passo, no lugar da cabeça, colocarão sôbre o pescoço dos homens uma bola, e vara os melhores uma corôa de $5.000 .000,00$ (os zeros sâo o zero do espírito que es tamos destruindo)

\section{Urbanismo}

A situação urbanistica em São Paulo já pode ser comparada àquele avestruz que para náo ser visto esconde a cabeç n areia. Receia-se de enfrentar problema em sua totalidade,

A pinacoteca-mirim dos alunos , cas do Museu de Arte figura nc durante o Congresso dos Escri:

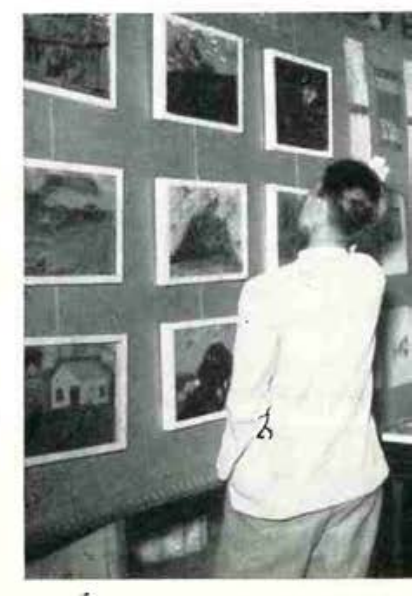

IMG 70

"Ipiranga".

[Habitat n.4, p.94] 


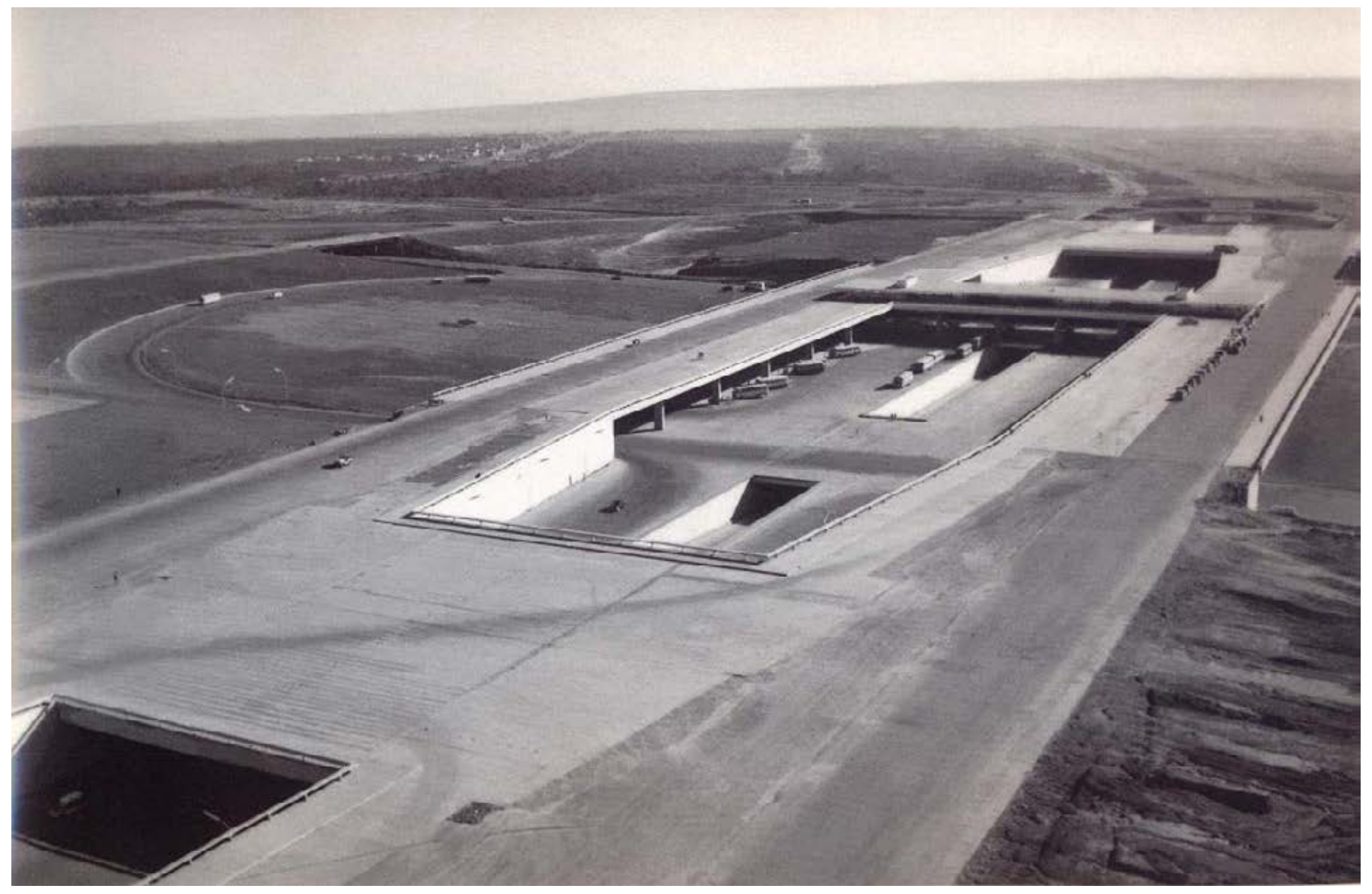

IMG 71.

Construção de Brasília.

[WASELY, 2010:493] 
PRÁTICAS

PEDAGÓGICAS

\section{MAMB}

\section{Exílio do Estado}

[...] Atrás dos mapas de Estado Maior e da vontade de dominar a silva horrida por meio da tecnologia e de um volumoso aparato militar, escondia-se um temor. A elite modernizadora do país, à qual pertencia Euclides, temia, assim como a tropa, o confronto com a geografia física e humana do país real: medo de perder-se no "labirinto de montanhas", no "labirinto das veredas" e no "labirinto das vielas" da "urbs monstruosa", espaço anárquico de uma população depauperada e crescente, que escapava ao controle e era o oposto dos ideais da ordem e do progresso. ${ }^{1}$

Antítese do mundo dos letrados, o sertão no processo de apreensão do território e do pensamento sociocultural brasileiro aponta para construção de grandes paradoxos, tão genuinamente intrincados ao entendimento da cultura moderna no país. Se o gesto inaugural de Euclides colocava em xeque a modernização oficial do Brasil, ${ }^{2}$ através de um inevitável crime fundador da unidade federativa então republicana, numa esfera social ampla, a construção de Brasília simbolizava um esforço coletivo em torno do ideal moderno, ${ }^{3}$ orquestrando a produção

1 BOLLE, Willi. grandesertão.br. São Paulo: Ed. 34, 2004, p.78.

2 CUNHA, Euclides da [1902]. Os Sertões [Campanha de Canudos]. 3ed corrigida. São Paulo / Rio de Janeiro: LAEMMERT \& C. Livreiros Editores, 1905.

3 Fazem parte do período o Plano de Metas do governo Juscelino Kubitschek, o Plano-piloto para a Poesia Concreta dos poetas concretos paulistas e o próprio Plano-piloto para Brasília, de Lúcio Costa. 
técnica e civilização tropical, perante aos amplos espaços vazios do planalto central do país. ${ }^{4}$ Nas palavras de Maldonado, imbuído de um orgulho "sul-americano":

(...) Com a criação de Brasília, temos pela primeira vez a possibilidade de ir para a frente, de abrir novas perspectivas. Não quero dizer que a tentativa seja inteiramente convincente sob todos os pontos de vista. Mas Brasília não é somente a realização de um estadista; é quase que um gesto de desespero da inteligência sul-americana para abrir novas perspectivas à nossa realidade terrível e dolorosamente fechada. ${ }^{5}$

Os anos JK iniciam-se embalados ao "clima de euforia e festa nacional se junta a sensação de que, além de ter encontrado seu destino autônomo, a nação atingiu por fim instituições estáveis e democráticas". Ao mesmo tempo em que Brasília se apresentava como uma oportunidade em escala para afirmação da articulação necessária entre arquitetura e indústria na condução de um empreendimento público dilatado na escala americana, sob o mesmo gesto incidia as contradições de um modelo econômico ambivalente na dependência entre investimentos públicos e privados na execução de seu parque industrial. Mostrava, sobretudo, as limitações acerca da racionalização da prática projetual e a distância do vocabulário dos termos da produção em série, cujo canteiro pautava-se por processos produtivos arcaicos e exploração de uma mão-de-obra desqualificada.

Brasília é uma tremenda oportunidade para o moderno planejamento de cidades. É uma grande possibilidade e ao mesmo tempo uma grande responsabilidade. O fracasso de Brasília seria um dos maiores traumas da cultura de nossos tempos. Tomás Maldonado, 1959.?
Ainda com a euforia relativa à indústria nacional, na perspectiva da Companhia Siderúrgica Nacional cujo emprego do aço apresentava um potencial de aceleração da produção, necessária para o tempo exíguo de construção da nova capital federal, as contradições da estrutura social brasileira que se tornaram expostas em Brasília colocavam em questão, inclusive, uma ideia de modernidade.

É preciso lembrar que a agenda desenvolvimentista de $\mathrm{JK}$, abriria a perspectiva do Estado enquanto coordenador do desenvolvimento que muito além do estímulo às empresas nacionais tornaria o ambiente especialmente favorável à entrada do capital estrangeiro, nas formas de aquisição de empréstimos ou mesmo investimento direto.

Assim, o parque industrial formado pelo capital externo atrelava-se à necessária infraestrutura viabilizada pelo Estado, que desde o segundo mandado de Getúlio Vargas centralizada o debate polarizado entre o "desenvolvimento autônomo e preservador das riquezas nacionais e [o] desenvolvimento associado ao capital externo", em torno do processo de industrialização do país e o correlato crescimento da classe operária urbana.

Esta aliança contraditória seria exponenciada nos anos JK e teria seus desdobramentos na continuidade da dependência estabelecida entre burguesia industrial, cujo crescimento industrial acentuava as agudas contradições do desenvolvimento, particularmente as do campo, ${ }^{9}$ onde as situações de miséria e atraso acabavam direcionando a mão-de-obra ociosa para os centros urbanos em processo de industrialização. Racionalização e subdesenvolvimento orquestrariam os paradoxos dessa experiência-limite para produção em massa, desenvolvendo, por outro lado, sistemas construtivos, como o uso do concreto

4 Juscelino Kubitschek chegou à Presidência da República, em 1956, com um plano de governo sob o lema: "50 anos em $5 "$ - composto de um ambicioso programa de metas, cuja meta-síntese era a construção de Brasília.

5 Tomás Maldonado. "As artes industriais". 6 6 sessão do Congresso Internacional de Críticos de Arte, 1959. Em Anais do Congresso Internacional de Críticos de Arte, pp.102-3.

6 Fausto, Boris. História do Brasil. São Paulo: Edusp, 2000, p.311.

7 Discurso de Tomás Maldonado no Congresso Internacional Extraordinário de Críticos de Arte, em 1959. Ver ref. "Opiniões dos críticos de arte". In: Brasília, ano 3, setembro de 1959, p.7.

8 Fausto, Boris. História do Brasil. São Paulo: op. cit., p.300.

9 Ibidem, p.320. 
protendido e da pré-fabricação, bem como a implantação de programas públicos relacionados à habitação.

Esse movimento em que a produção artesanal seria substituída pela produção industrial, de maneira acelerada, acarretaria um processo de centralização de capital, mudando de forma abrupta a estruturação econômica ao colocar em xeque o discurso nacionalista face a abertura ao capital estrangeiro. $O$ próprio encerramento das atividades de Lina em São Paulo, ligadas ao mundo industrial tanto no Studio Palma, quanto no IAC, refletiriam a incapacidade da burguesia industrial brasileira enquanto protagonistas de um processo econômico autônomo. Na direção da finesse denunciada por Lina, o modelo de desenvolvimento passaria efetivamente à abertura ao capital estrangeiro associada ao capital estatal, não apenas mudando a direção econômica do país, mas redefinindo sua orientação política democrática, como se tornaria evidente com o golpe de 1964.

\section{brasilien baut brasilia}

IMG 72. 


\section{Diario de Nouthuost}

Cldade do Salvacor - dorvingo, 10 de agosto de 1958

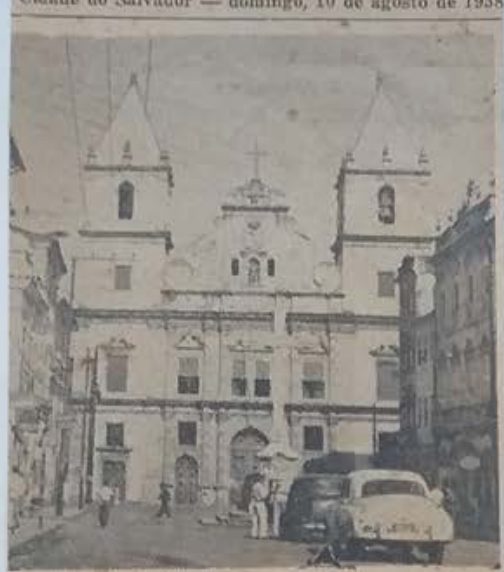

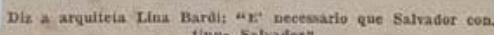

Lina Bó Bardi tornou-se nome conhecido em tocio o pais como diretora da revista de cultura "Habitat" que se imprime em Sảo Paulo. E também vinculou-se estreitamente com a obra de seu marido P. M. Bard, - organizador do Museu de Arte de Sío Paulo, hoje vallosissino patrimonio pictorico, acumulado gracas a tenacidade invencivel do embaixador Assis Chateaununciou na Escola de Belis Artes duas conferéncias nunciou na Escola de Belis Artes duas conferências que se tornaram famosas e obrigaram à autora a re gressar a Bahia, agora com encargos mals complex. tres méses na Cadeira de Teotia de Arquitetura.

Nas conferenncias de abril, Lina Bo Bardi trato da "Crítica de Arquitetura", preocupando-se tamberm do "Problema Especial na Arquitetura". Formada em 1940 pela Faculdade de Arquitetura da Universidade de Roma, logo depois da guerra radicou-se no Brasil onde encontrou vasto campo para o exercicio de sua profissia.

\section{A FUNCAO DO ARQUTTETO}

A Teoria da Arquitetura, como a proprla ArquiLetura, nao esta ainda totalmente situada como cienpha Ate ha pouco era admitida como abstraça metaficica seu ensino era orientado no sentido de artc, com uma predominancla de preocupaçáo estética. O rumo atual leva esse ensinamento a uma responsabilidace moral ademals de artistica. Essa responsabilemove capitais privados e públicos; $2^{0}-$ a obra do arquiteto deixou de ser algo intimo e subjetivo, mas ao contrírio se externa em obras que dizem respeito a todos. O edificto tipleo da arquitetura atual e a casa do homem - residéncia individual ou casa popular. 0 arquiteto passa a sugerir e mesmo a influir de veras no modio de viver do homem moderno, até mesmo na sus formasa inteloctual. Modifica o estitho de vicia FIM DOS "FACIIfDISTAS

Nio so aqui na Bahia, mas em todo o pais

mesmo em toda o mundo. a Arouitetura funcionava
DIAŔRIO DE NOTICIA SALVADOR - BA

$10-\triangle C O-1958$

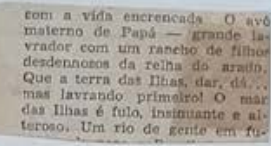

Adverte Lina Bo Bardi:

\section{MUITO CUIDADO COM SALVADOR}

Texto de Napoleão Lopes FILHO

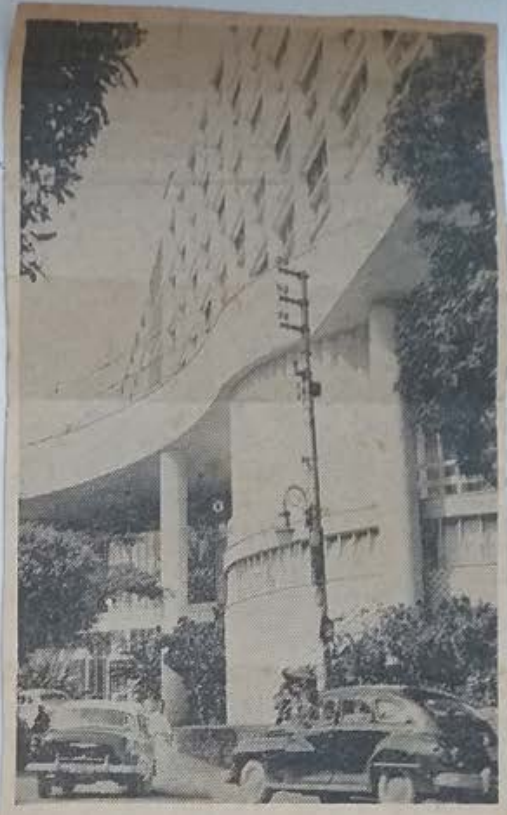

Sraito culdade para que o moderno se interre no eppirito
da eldade

paises. No entretanto, a pressa e a falta de reflexão ficam aquela opinia de Max Bll.

Agora terminou-se um ato da arquitetura brasiroutetos nacio eus estâ, hrocurand adescencia. Os necessidade de fazer uma revisão critica enquadrandes que seriam satisfatórios as necess. do pais. Na pensar que necessidade do pais tido em arte. Necessidade a que se refere a tem sentrevistada é de "correspondéncia ética e funcional".

\section{ARQUTTETURA NA BAHIA}

"Na Bahia, principalmente em Salvador, não focomo um apendice da Escola de Belas Artes, era ums ram ainda aproveitados os fatores que poderiam dar atividade romantica, o arquiteto era o desenhador de a sua arquitetura um conteudo vital". "E isto porque fachadas bonitas, era em suma o "fachadista", nada - acrescentou dona Lina Bardi - nầo fol utilizado casa. A construearoo corria por conta de um mestro propriamente aquilo que individualiza a cidade, o obras. A tendéncia moderna e a do arquiteto vol. nio identifi que Salvador continui sendo Salvador e tar ao conceito medieval de trabalho, êle sera como oula rem sendo, a figura complexa que construlu as gran- tensamente "modernas" " Acsim, na co prudente de des catedrais da Idade-Medita - o magister. Este fasin molir porgue sim, is cegas, mesmo os casas modestas tudo, descle o desenho, realizava com construtor e năo dos bairros afastados essas coloridas easas modestas

raro fazia o trabalho manual como operario.

\section{AROUITETERA BRASILEIRA}

A Arquitetura brasileira despertou logo depois B R A S IL I A

Em geral, as cldades nascem pela conjunçĩo do nos a Sra. Bardi. O critico de renome mundial Gig. fatores externos, se aglutinam casas onde a topograrid Gedion citou a arquitetura brasileira funtamente la e a conjuntura economica insinuam que isso se om a sueca, como a mais adiantada do mundo. Outra de. As cidades planificadas sĩo raras. Ema geral sấo pinicio critica que tambem projetou a arquitetura obras impostas pelos ditadiores. O caso de Brasilia, trasileira fol a de Max Bill, que, contudo, achou a ta oplniao da arquiteta Lina Bo Bardi e dos mais innossa "arquitetura demasiadamente exibicionista e tessantes porque esta sendo levado a cabo num pais ndividualista, sem a devida responsabilizaçāo social". denocratico. Essa experiencia e inedita e não se pode Entre os dois polos, 6 evidente que a arquitetura bra- pretgurar o seu futuro. A arquiteta fina Bardi acha sleira tem importäncia notável no mundo contempo- rada "inteligente mas perigoso". Uma capital precisa arquiteta Los solucōes leves - continuou a opinar se constituir em organismo urbanistico, e isso implica da arouitetura brasileira, náo se encontram em outros em correlacáo verfeita entre o regional e o naciona (Cobclue da 2a. Plgta)

IMG 73.

Adverte Lina Bo Bardi. 


\section{Um olho sobre a Bahia}

Entre o final da década e 1950 e início dos anos 1960 convergia na Bahia uma intelecualidade, de matriz próxima das vanguardas, concentrada ao redor da Universidade Federal da Bahia que, embalada pelo compromisso de redemocratização da cultura, colocaria Salvador no epicentro das discussões contemporâneas sobre arte, produção e circulação de linguagens, em novas estruturas semânticas que extrapolavam o vocabulário construtivo.

Assim, a primeira passagem de Lina pela Bahia, a partir de agosto de 1958, a colocaria num ambiente fecundo para pensar de forma direta as relações de produção da cultura popular nordestina como um "caminho" para a revisão crítica que se impunha ao modelo de desenvolvimento adotado pelo país. Ali, estariam perspectivados o debate acerca das massas trabalhadoras em plataformas culturais e artísticas, que teriam ampla ressonância em suas ações pedagógicas.

Um mês após as palestras de Lina na Escolas de Belas Artes, realizada em 22 de maio de 1958, o diretor Mendonça Filho a convidaria para colaborar na Cátedra de Teoria e Filosofia da Arquitetura ao lado de Diógenes Rebouças, no segundo semestre do mesmo ano. $O$ conteúdo preparado para este curso, desdobrava as questões de teoria, enquanto práxis, elaborada no ano anterior na ocasião de sua tese, promovendo um debate acerca do papel social do arquiteto no Brasil. 
Os alunos estavam entusiasmados. Dava aulas ao quinto ano, mas eles vinham de todos os anos. Era muito bonito, os estudantes eram muito inteligentes, havia diálogo, também debates. Foi uma época muito bonita, quando Salvador estava na linha de frente do Brasil. A universidade era formidável, tinha uma Escola de Teatro belíssima, a Escola de Música com Koellheuter, a de dança com Yanka, uma escola muito livre (...). ${ }^{10}$

Nessa atmosfera condensadora que colocava Salvador como polo irradiador de produção para além das metrópoles do sul, Lina encontraria um ambiente sujeito à conscientização da sociedade brasileira sobre a eleição desse banquete que preparava a partir dos elementos culturalmente válidos e, portanto, autênticos, descentralizando o valor da cultura dos mecanismos seculares de manutenção do poder na insubordinação das massas, num processo de democratização necessário para o fortalecimento das instituições e soberania de seu povo, então privado dos seus direitos políticos. Esse movimento carregado de potência nos desdobramentos da agenda didática iniciada em São Paulo na década anterior, teria o papel de emancipar o país de sua "subordinação cultural"."

A guerra que as novas gerações devem abrir contra a província deve ser imediata: a ação cultural da Universidade e do Museu de Arte Moderna são dois tanques de choque (...) os clarins da batalha foram tocados pelas grandes exposições do Museu de Arte Moderna e pela montagem da Ópera dos três tostões de Brecht que provocaram grande excitação no pensamento pequeno burguês. (...) Gostaria que todos vocês que lideram nosso verdadeiro pensamento se empenhassem para levar a Bahia um passo a frente. Porque, se agora não agirmos no dia em que o governador Juracy, o escritor Jorge Amado, o cantor Caymmi e a bela Marta estiverem mortos, a Bahia não passará de uma digna sepultura saudosista. ${ }^{12}$

Evidente que a eclosão da Tropicália enquanto um dos maiores fenômeno da história da cultura artística no mundo na esteira desse movimento, elevaria os bastidores dessa efervescência iminente a serem extenuamente cansagrados a uma análise combinatória supra-sensível, capaz de reunir pessoas de "grande gênio", ${ }^{3}$ e cujos fatores dessa equação tendem a se tornar mais interessantes, a partir da narrativa comprometida de Risério que sintetiza a amplitude de realizações do período como um movimento de avant-garde. ${ }^{14} \mathrm{Ali}$, os termos das vanguardas apresentadas dizem menos sobre a definição de uma linguagem estética e mais como a soma de esforços muito diversos em sua natureza - artística, editorial e institucional - pautados por uma experimentação autônoma de linguagens, afastou a Bahia para longe de seu provincialismo secular. Nas palavras de Lina:

A Bahia viveu o esplendor de um conjunto de iniciativas que representavam uma esperança muito grande para todo o país, estendendo-se do extremo até pelo menos, o Rio de Janeiro (São Paulo ficou de fora, infelizmente). (...) Foi um discurso sociopolítico, vinculado diretamente à Economia e História do Brasil. Foi um processo que ocorreu não está sozinho ou na Bahia, mas em todo o Nordeste, e que não pode ser abolido. Em Pernambuco, no Triângulo Mineiro, no Ceará, no Polígono da Seca, havia um fermento, uma violência, uma coisa natural no verdadeiro sentido histórico de um país, que era o conhecimento de sua própria personalidade.15

Sob o comando do reitor Edgar Santos, o substrato antropológico local seria redimensionando ao cosmopolitismo, a partir do "treinamento artístico realizado

10 Olivia de Oliveira, "Entrevista com Lina Bo Bardi", 2 G n. 23- 24, op. cit.: 250

11 Cf. Lina Bo Bardi, "Um balanço dezesseis anos depois", em Tempos de Grossura: o design no impasse, op. cit., 11.

12 Glauber Rocha, em 1961 Salvador, Suplemento de Artes e Letras, em 5/02/1961] (Gerber,1977:23).

13 Rogério Duarte em entrevista a Raquel Gerber, realizada em São Paulo, em dezembro de 1974. Em Raquel

Gerber "Glauber Rocha e a experiência inacabada do Cinema Novo", em Glauber Rocha, op. cit. 2.

14 RISÉRIO, Antonio. Avant-garde na Bahia. São Paulo: Instituto Lina Bo e P. M. Bardi, 1995.

15 Lina Bo Bardi, depoimento para o livro Arte na Bahia. Teatro da Universidade (Salvador

da Bahía: Corrupio e Empresa Gráfica da Bahia, 1991), 12. Arquivo ILBPMB. 
por criadores ousados", como relembraria Caetano Veloso. ${ }^{16}$ Para tanto, a universidade atuaria como palco experimental para numerosos artistas de vanguarda nacionais e estrangeiros, com o apoio do governador do estado Juracy Magalhães. ${ }^{77}$

Alguns núcleos espraiariam a universidade na vida ativa de Salvador, como a Escola de Teatro, dirigida por Eros Martim Gonçalves que, dentro de sua dramaticidade controversa, trazia às obras de Brecht. Da mesma forma, os Seminários de Música, coordenados pelo músico alemão HansJoachim Koellreutter, introduziriam a música serial-atonalista dodecafônica, abrindo um campo experimental de produção de linguagem musical. Na dança, a ex-professora do MASP, Yanka Rudzka, trazia a linguagem da arte contemporânea. ${ }^{18}$

Além disso, de extrema importância seria o aval que Edgar Santos daria à implementação do Centro de Estudos Africanos e Orientais, na Faculdade de Filosofia e Ciências Humanas da Universidade CEAO -, ao filósofo português Agostinho da Silva. Essa iniciativa iria fomentar a pesquisa sobre as raízes africanas da cultura popular local, por meio do estudo das práticas do Candomblé e da Umbanda, cuja censura policial estava colocada desde 1930. Pelo CEAO haveria um fortalecimento dos laços culturais que relacionavam o Brasil às nações orientais, inclusive, estabelecendo relações diplomáticas nas antigas colônias africanas.

No âmbito editorial, a universidade forneceria apoio às duas revistas associadas à militância dos jovens estudantes baianos: Angulos e MAPA. A primeira, editada pelo Centro Acadêmico da Faculdade de Direito da Universidade Federal da Bahia, entre 1957 e 1961, Lina Bo Bardi contribuiria com o artigo "Artes Menores. Notas para criação de uma cadeira de Desenho Industrial", direcionando às vanguardas a ideia de desenho industrial, cujos argumentos continham a gênese da ideia de

16 Caetano Veloso. "Apresentação", em Risério, A. Avant-garde na Bahia, op. cit., p.9

17 Líder da UDN local, Juracy Magalhães, dividia sua orientação política conservadora com reitor Edgar Santos. Ver. Cf. Antonio Risério, Avant-garde na Bahia, op. cit. 32

18 Cf. "Dançado. Conjunto de dança expressiva", Habitat 7 (abril-junho de 1952): 83. 
universidade popular que seria, pouco tempo depois, o condensador pedagógico do programa para o Museu de Arte Popular do Unhão - MAPU. ${ }^{19}$

A segunda publicação, a revista $M A P A$, pertencente à Associação Baiana de Estudantes Secundários, circularia entre 1957 e 1958 e, como a anterior, se distinguiria do conservadorismo ideológico da imprensa local e, com apenas três números publicados, seria um meio importante para a disseminação das novas linguagens. Um meio que seria marcado pelo "marxismo barroco tropicalista" expressão cunhada por Glauber Rocha ${ }^{20}$ na contramão do conservadorismo secular da imprensa baiana.

A relação de Lina e Glauber gravitaria, em um primeiro momento, em torno do Diário de Notícias, por meio da contribuição de Lina à página dominical do suplemento artístico-literário dirigido por Glauber. Além disso, integrariam à dinâmica da Escola de Teatro da Universidade Federal da Bahia, Glauber como aluno e Lina na direção das muitas relações contíguas entre o Museu de Arte da Bahia, e a Escola de Teatro." Estariam juntos também na exposição Bahia no Ibirapuera, em 1959.

De volta a Salvador, Glauber seria membro ativo do cineclube nos seminários de filmes do crítico Walter da Silveira, onde se realizavam debates teóricos e políticos sobre os filmes neorrealistas italianos, soviéticos, entre outros, cujo desdobramento seria o próprio Cinema Novo. Risério frisaria sua importância, junto à Escola de Teatro, para formação estética de Glauber Rocha e "seus vínculos com o teatro brechtiano, o cinema de Eisenstein, a nouvelle vague e os escritos críticos dos “Cahiers du Cinema'. "”

Lina acompanharia as filmagens de Deus e Diabo na Terra do Sol, no sertão nordestino, em Monte Santo - emblemática Canudos - em junho de 1963. Das trocas escritas, estariam um texto não publicado de Glauber, para a Exposição Nordeste, em $1963^{23}$ e, de Lina, o texto "Il Provincialismo Accademico della Dolce Vita", arquivo do MAMB. Das referências que produziram mutuamente em suas trajetórias, Glauber destacaria a importância da montagem Ópera de Três Tostões, de Bertolt Brecht, cujo cenário seria desenvolvido por Lina.

19 Bardi, Lina Bo. "'Artes Menores'. Notas Para Criação Duma Cadeira de Desenho Industrial". Ângulos 16 (dezembro de 1960): 121-124.

20 Em Antonio Risério, Avant-garde na Bahia, op. cit. , 62, citando Glauber Rocha na Revolução do Cinema Novo. São Paulo: Cosac Naify, 2004, 344.

21 Inclusive na conferência "Arquitetura como Habitação". Programa de curso, 1961. Acervo ILBPMB, reproduzido em Arte na Bahia. Teatro na Universidade, op. cit., p.9.

22 Antonio Risério, Avant-garde na Bahia, op. cit. 136.

23 O texto foi incluído posteriormente no livro Tempos de Grossura: o design no impasse, op. cit. , 65-68 


\title{
"Artes Menores"
}

\author{
Notas Para Criação Duma Cadeira \\ de Desenho Industrial
}

\section{Lina Bardi}

Alguns manuais de História da Arte definem ainda hoje como "Artes Menores" a atividade artística ligada à vida "prática". 0 conjunto das manifestações artísticas não "gratuitas" (dizemos "gratuito" no sentido de afastado dos fins imediatamente práticos) como a pintura e a escultura. "Artes Menores" seriam os objetos de uso cotidiano, os pratos e os copos, os acessórios sacros e profanos, as cadeiras, os tapêtes e as estalas, as tapeçarias e as jóias. Sob esta denominação, relegada às últimas páginas dos manuais, geraçōes de estudantes têm desordenadamente acrescentado como apêndice às suas noções de História da Arte, a imagem da cadeira de Maximiniano, da Coroa de Ferro e das tapeçarias de Rafael. Hoje, as "Artes Menores", sob a denominação de Desenho Industrial, são reunidas crìticamente, no domínio da Arte Prática por excelência: a Arquitetura. Mas qual é o significado real, na vida de cada dia, do "Desenho Industrial", que, nos países sem estrutura industrial é ainda artesanato? 0 que por tantos séculos foi no ocidente uma produção destinada a classes privilegiadas, uma exceção ligada a uma liderança cultural, está hoje tornando-se a maior expressão cultural da civilização contemporânea ocidental. O Desenho Industrial desbancou a expressão "decorativo", adjetivo desprestigiante, usado especialmente por uma crítica de arte que encarava as artes plásticas em função da "Arte" ligada exclusivamente a problemas formais que excluem o lado humano, reduzindo a obra de arte a uma criação abstrata no espaço e no tempo. O homem total, completo em cada uma de suas expressões, o homem não "alienado" que vive plena e completamente a sua experiência humana, não poderá prescindir do fato estético que o acompanha cotidianamente, não como uma forma de "requinte" decadente, mas como explicação de um dos valores mais importantes de sua totalidade humana: o estético. 0 objeto de uso comum "belo" (usamos a palavra no sentido não filosófico), o amor ao particular cuidado e simplificado, serão, para o homem ocidental os novos valores de uma cultura prática, técnico-estética e essencialmente anti-teórica (no sentido que a palavra teórico possui de "fendido" da realidade e de nebuloso na cultura tradicional do ocidente). Um

121 


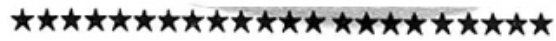

\section{Nordeste}

\section{Gi.Aurer Rocha}

Guimarães Rosa, nas palavras sábias de Riobaldo Tatarana - após o jagunço girar na sua guerra de toda a vida os caminhos do sertảo - decreta que o "Diabo não existe. $\mathrm{O}$ que existe é homem humano. Travessia".

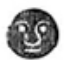

O Mestre Guima ó mineiro (outro sertão, mas penso que tudo são gerais - abertos nas Alagoas ou fechados nas matas de cacáu de Ilhéus). Gerais maiores, mais perigosos que as grades de cipó ou macambira: da chapada sêca, por onde Mestre Graça (e agora Nelson Pereira dos Santos) leva as vidas de Fabiano Pereira dos Santos lé Vitória até as veredas inFabiano e Sinhá Vitória até as veredas in-
trincadas de Hermógenes, tudo é a mesma coisa, segundo a resposta de João Cabral (dos penitentes a Severino): fome e sêde e privação.

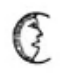

O certo é que - nos confins do sertão "Deus criou o mundo e o diabo, o arame farpado". Nåo é outro o motivo que explica a grande força da literatura brasileira jusa grande força da literatura brasileira justamente nas matarias e chapadas, onde anti-
gamente imperavam as leis dos feudos megamente imperavam as leis dos feudos me-
dievais, com seus cavaleiros subnutridos nas armaduras de couro. O jagunço é um pobre valete que nada leva de si a não ser scu destino submisso ao destino do senhor: assim foram colonizadas as margens do São Francisco, de onde saiu a pior tradição das nocisco, de onde saiu a pior tradisăo das nobrezas, desde as Minas Gerais de Guimarães cruel narrativa de Graciliano Ramos.

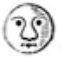

Nõo vale mais a sentença clássica de Euclides: o sertanejo não é, antes de tudo, um des: o sertanejo náo e, anter cervo da mais primitiva condição, é um fraco e um passi- vo: sua resistência já é na própria morte, não é na vida: a impotência mental e física está/ presente em seus atos cotidianos e êle só ameaca se libertar da preguica se estimulado pelas alienações do misticismo: não é necessário que lhe seja apontada (ainda) um destino real: nos campos do Monte Santo, destino real: nos campos do Monte Santo,
Trapagó, Quinquiriqual, Acaru, Cocorobó, Trapagó, Quinquiriqual, Acaru, Cocorobó,
Quebroguenem eu os vi (aos grupos) lamenQuebroguenem eu os vi (aos grupos) lamen-
tar a ausência de D. Pedro II e dispostos a morrer em outra guerra (e exclusivamente nesta), desde que ela fôsse em nome de Deus e do Imperador. Nús e paralisados ainda estão com a fôrça transferida para as mãos do Bom Jesus.

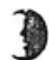

meninos morrendo por hora, barranqueiros, barqueiros, tropeiros, talvez outros cangaceiros, boiadeiros - as mulheres no asfixio do fumo, na tortura do/ cortume, no ciclo da moenda, os homens da dureza da sola, em volantes de caminhōes por sōbre buracos que se ausentam sob um contraditório asfalto. Piores habitaçőes, choupanas de sopapo, palafitas e buracos na caatinga; pedreiras re motas, cabras balindo, magras vacas, campelinos, porcos e carneiros de cinza lã - e a casa grande e a senzala, devidamente celebrados.

No mais é uma frase atribuída a Cristino Gomes, vulgo Corisco, cangaceiro de Lampião, morto em maio de 1939 pelo Major José Rufino: - Mais fortes são os poderes do povo! - isto na hora da morte, cravado de balas. Eu pelo menos, entre as testemunhas. (e ouvi) assim

E: nossivel visagem de almas, visão de ilhas, revelaçōes de esperanças nos pelados de $\mathrm{Co}$ corobó: ali estão velhas nobrezas destruidas de jagunços e generais numa guerra sem outra glória a não ser aquela absurda da histerica morte, da autopunição de uma raça débil, de um flagelo bíblico; e a herança de débil, de um flagelo bíblico; e a herança de
tal glória năo poderia ser esta de hoje, nuntal glória năo poderia ser esta de hoje, nun-
ca as medalhas de heróico civismo ou monuca as medalhas de heróico civismo ou monu-
mentos hipócritas. Não temos heróis nem "Os Sertōes" é uma epopéia: antes, um relato triste e escandalizado, uns mitos chinfrins, uma revelação mórbida de que até mesmo o homem humano é tão débil (na sua Diabo. O milagre, que não vem/ dos terços desfiados nas cantilenas infinitas, não virá desfiados nas cantilenas infinitas, não virá inclusive como milagre. Mas seria outra loucura pensar, agora, que o nascimento de uma nova raça virá da pura consciência de avós e pais: é a mais negra das demagogias, a mais escura das mentiras. Será necessário uma nova mentira, desta vez mais útil. Armar um palco nos gerais, transformar a visagem em espetáculo.

Procuro o drama, êle não há: fixou a debilidade com raizes profundas. Mestre Graca não teve a menor piedade, desfiou até a última fibra, encontrou o que era de há muito, sem adjetivos, sem riquezos a não ser aquesem adjetivos, sem riquezas a ná ser aque$\mathrm{E}$ de que adiantam êstes simbolos da violência e da morte, para que servem as heranças apodrecidas da idade média? E uma vergonha cercada de arame farpado. Nem é um campo de concentração, não chega a ser um tutano, um caule - e os que se comem são de bois magros ou de insossas macambiras. E é mais transparente dos olhos até os fundos o interior é uma sala com uma/ rede nos cabos e uma fina cruz do Cristo.

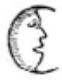

Eis a cultura e suas honras: as vestes de couro, as panelas de barro, as cabeças de madeira, os chicotes, os fifós de lata, o carro/ de boi, os guizos das vacas, as bruacas de couro de cabra e os alimentos mais dignos: a mandioca, o umbu, agua também, osso com algum tutano, mandacarus e cabeças de frade, farinha e carne de bode, a rapadura, milho. a cajarana e outros tantos frutos e cereais que mal alimentam. E ainda os remanescentes da vida, pistoleiros e prostitutas emigrando, camponeses arando o nada, tantos 


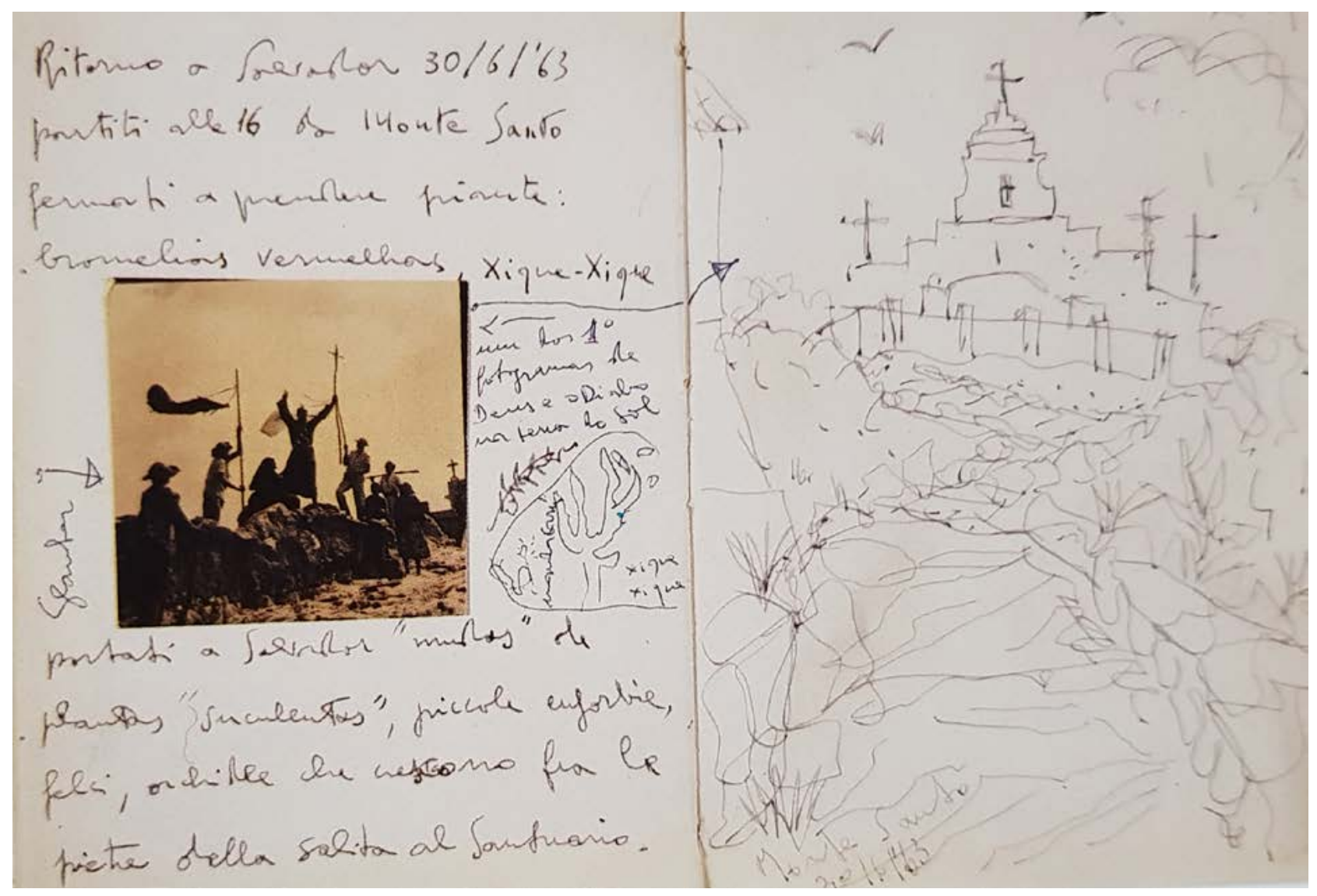

IMG 75.

Texto Glauber Exposição Nordeste, 1964.

[Mirante das Artes, n.6, dez, 1967]
IMG 76.

Diário de viagem.

[FERRAZ, 1993:142] 
a Slouber Rocha.

Il Provincialismo Accademico della "Dolce Vita"

\section{desumiat}

Solo a chi sia sprovvisto di vere basi e di ana buona informazione culturale contemporanea, ( per cultura intendiamo non solo dats conoscenza di"nozioni" ma bensi tutto l'insieme di cognizioni reali di vita, dall'economia all'arte al costume, unite a una serena capacità di giudizio) può vedere nel film di Fellini una critica alla società contemporanea, o, come ha scritto Alberto Moravia in Italia, un corrispondente contemporaneo del Satiricon di Petronio.

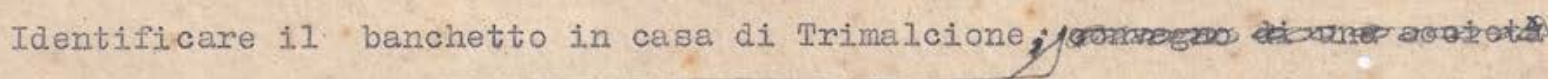

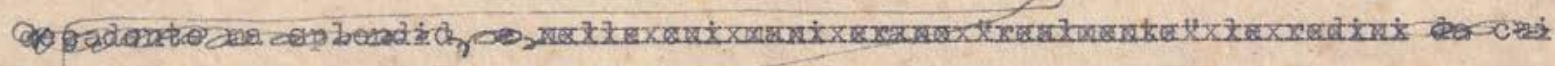
desperco va Con

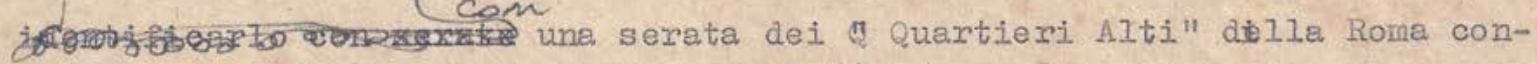

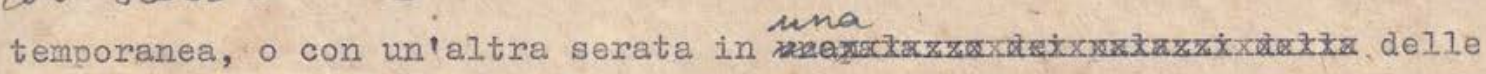

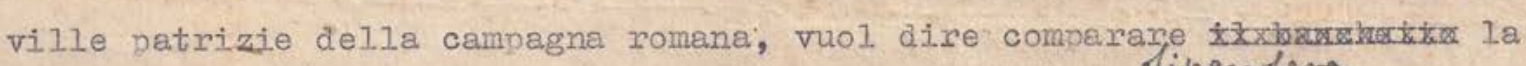
cripendeva

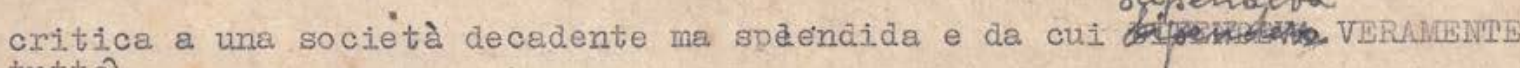
tutto)

Cil mondo di allora, a una società da cui dipendono oggi VGRAMENTS solo i. cemerieri dei caffe di via Veneto e le boutique di moda aperte dalle stress signore disocupate.

Qustograxe A questo grave emore di impostazione critica fà riscontro la "posizione culturale del regista del film. B una posizione di "compiacenza" di una situazione che è estremamente utile a dare risultati bxillanti (in

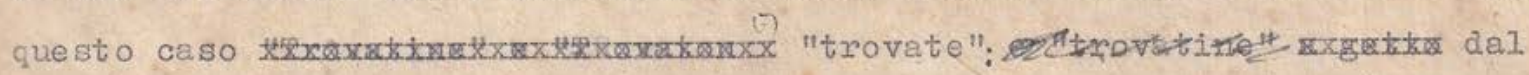

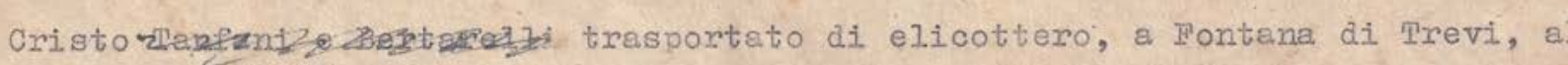

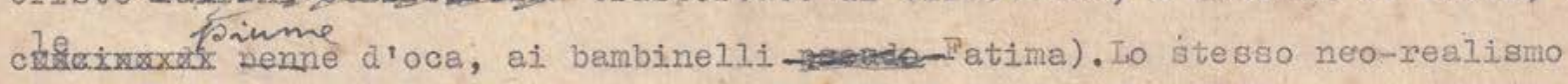
si costitui in Italia non tanto come critica sociale ma come "mezzo" autocosciente e autocompiaciuto di una situazione che psovortteraxta dava sensazionali spunti e permetteva bellissimi film. frastaquesta

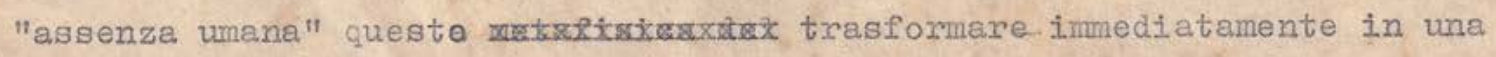
metafisica astratta una realtà umana, questo teoricizzare estremo, brillante intelligentissimo, questo spogliare di ormi tragicità wemenle più tragiche situazioni per ridurle a una brillante esibizione personale, questa o la ver 


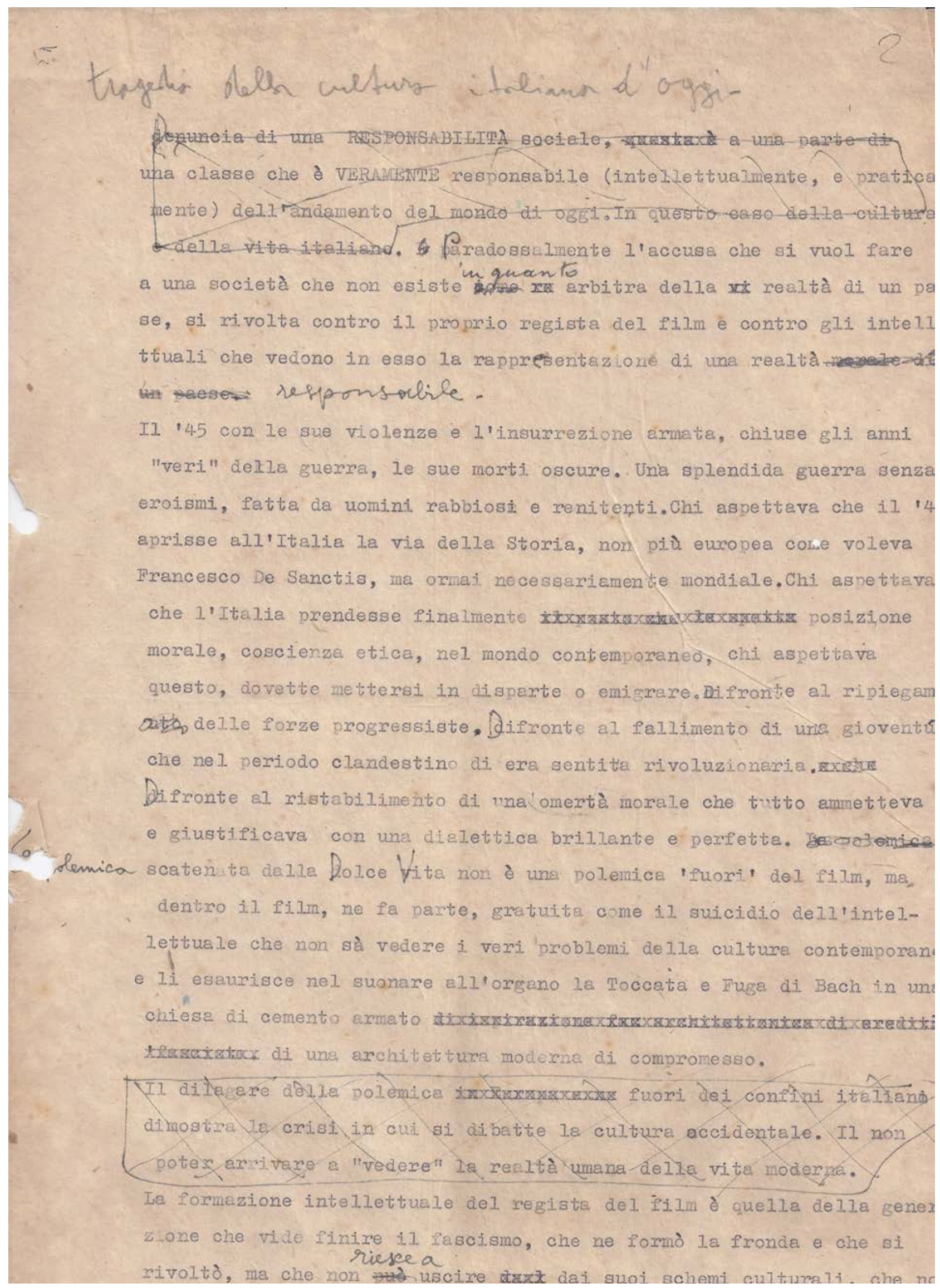

IMG 77. 


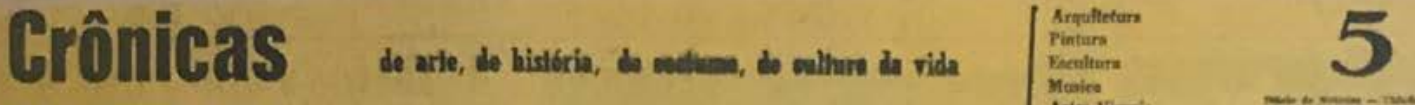

\section{Casas ou Museus?}
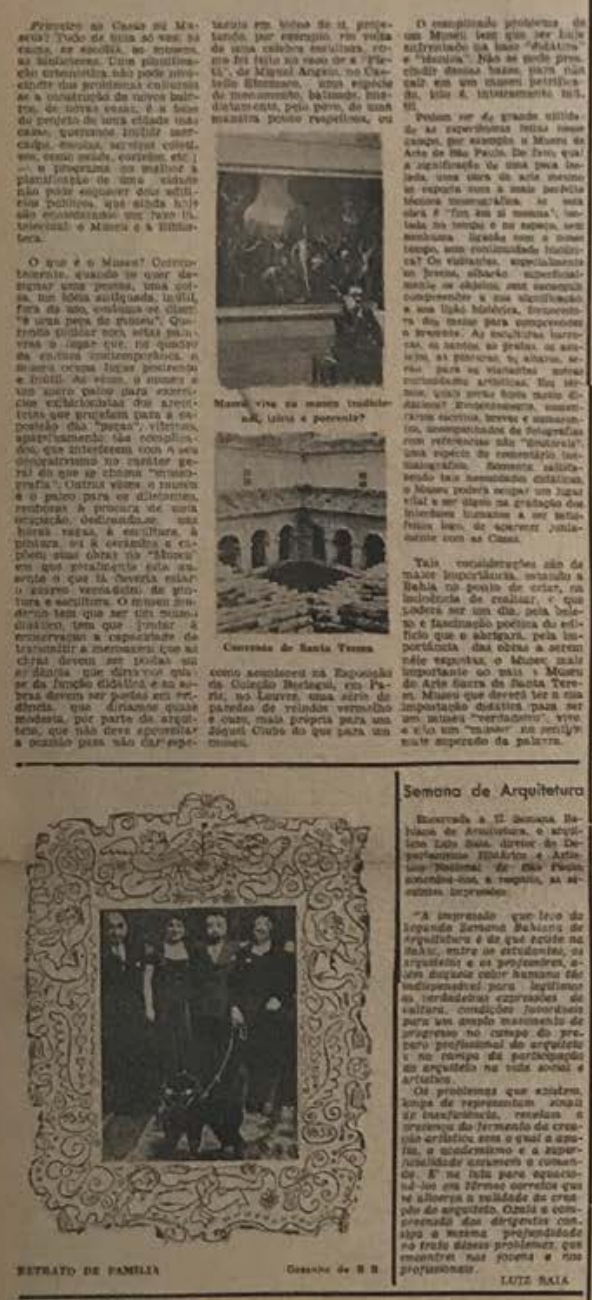

\section{ANTOLOGIA

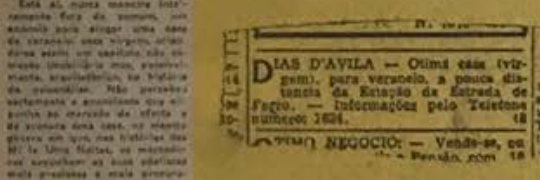

DOCUMENTOS:

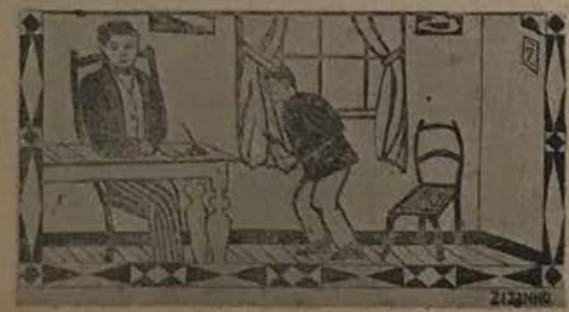

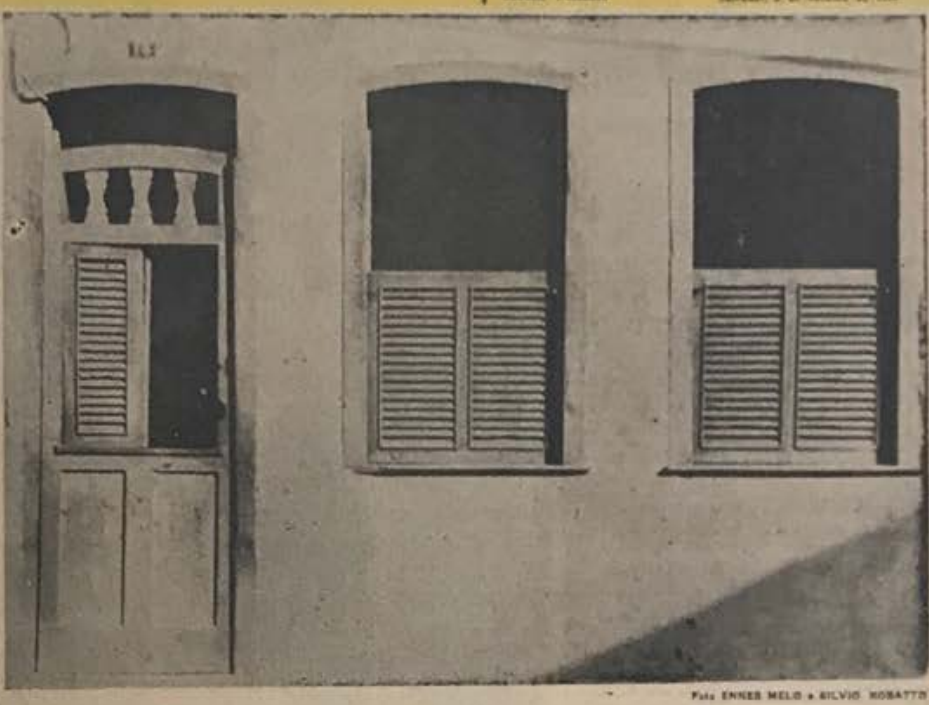

\section{T0. Ôlho sôbre a Bahia}

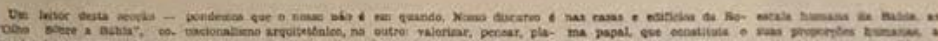

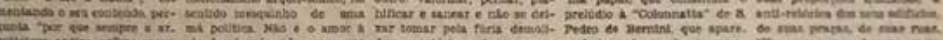

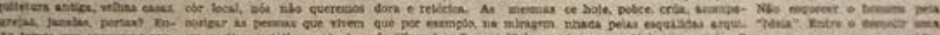

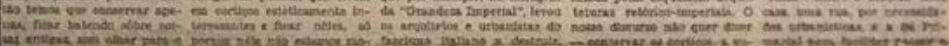

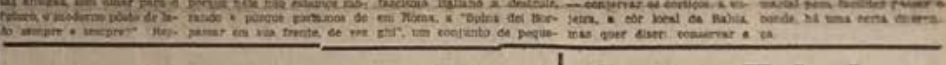

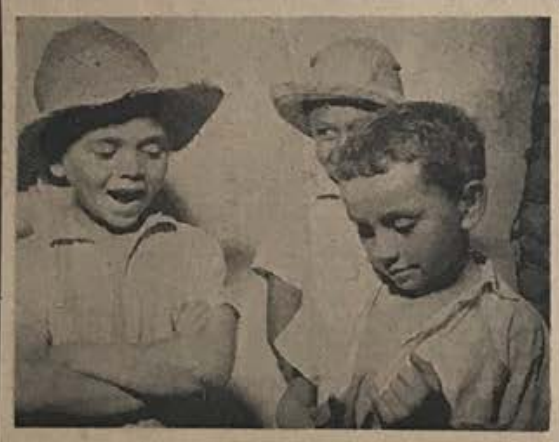

Sôbre a problemática da música de nosso tempo H. .. KOELQREUTाER

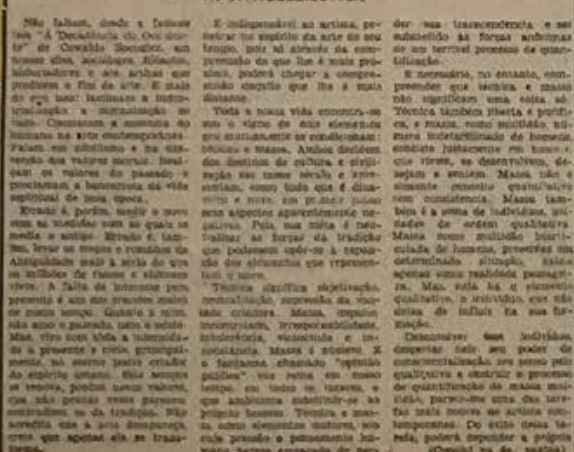

\section{Anton Tchekov} (Primeirios anotoşés pora un ettudo

Gionni RATTO

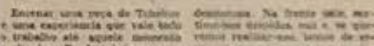
$-5=-5=5$

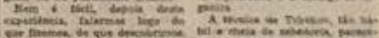

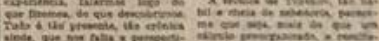
$-3=\sin x-5$

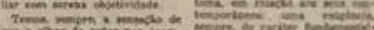

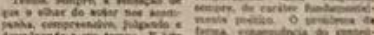

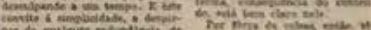

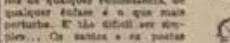

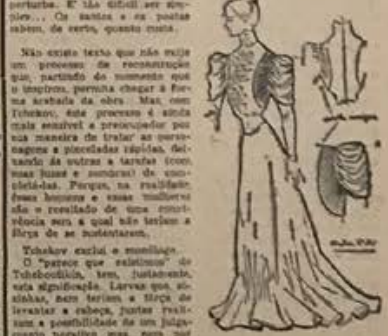
$\Delta=-\pi=-2=-$

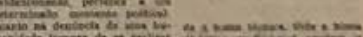

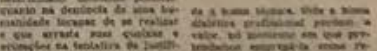
$5=-5=2=$ $-2 x-5=5-5$

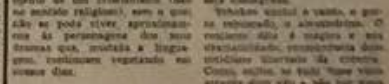

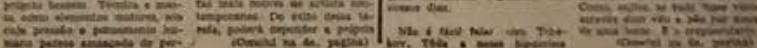


Nas páginas culturais de domingo do jornal Diários de Notícias, Lina publicaria oito edições consecutivas, entre setembro e outubro de 1958, na seção Crônicas de arte, de história, de costume, de cultura da vida (Arquitetura, Pintura, Escultura, Música, Artes Visuais).

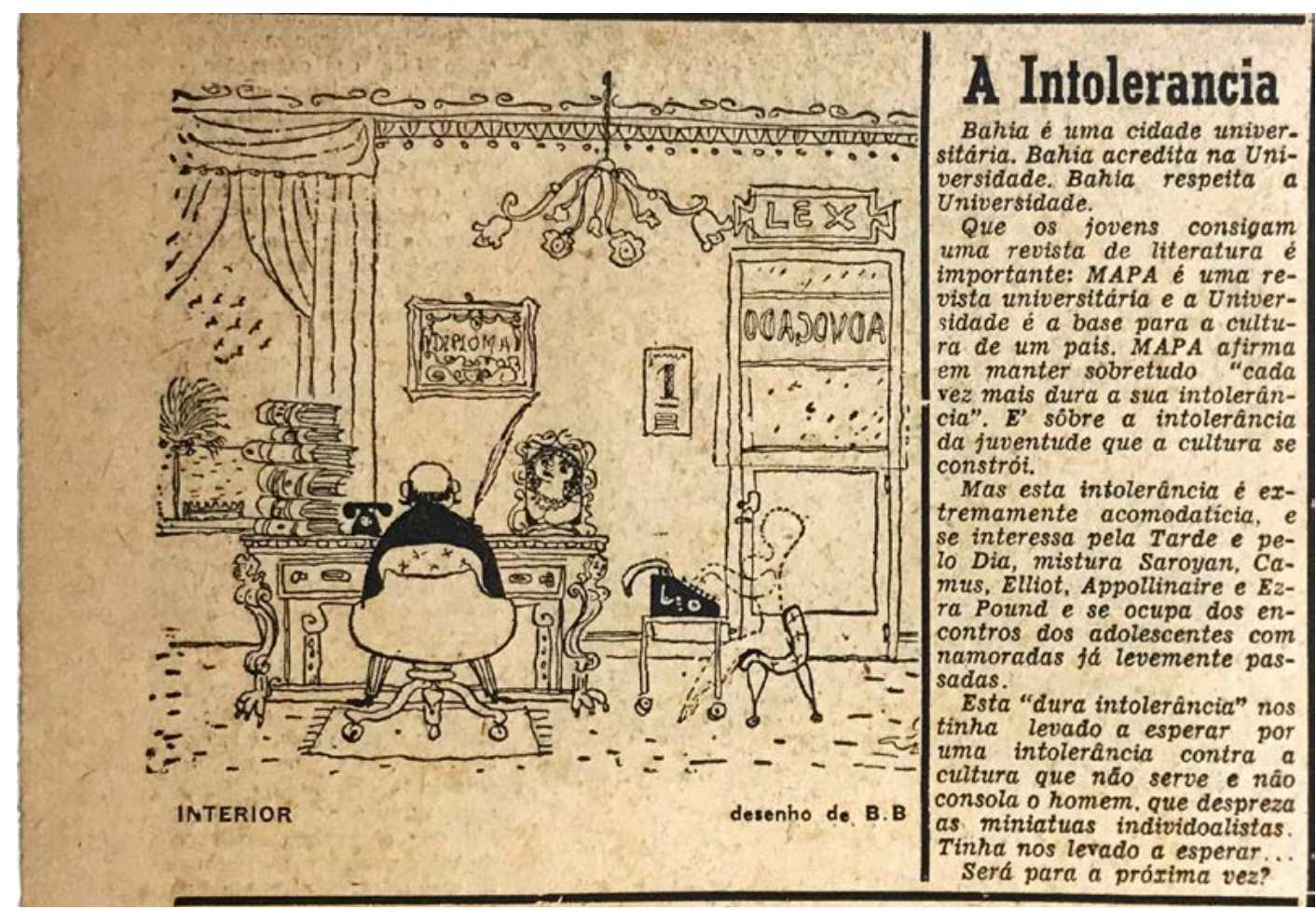

Neste espaço, Lina contrastaria o estado obsoleto e conservador da cidade de Salvador ao esforço progressivo e popular embalado pelas vanguardas aglutinadas ao redor da Universidade Federal. Dentre seus representantes, o maestro Hans Joachim Koellreutter escreveria sobre música, ao lado de Lina, além das contribuições sobre teatro por Martim Gonçalves e artes, por Mário Cravo.

Os escritos de Lina no suplemento de domingo Diários de Notícias promoveriam um diálogo com jovens militantes, na direção de fomentar um treino crítico na muitas vezes em combate com o personalismo incômodo do monopólio exercido pela ideologia do Partido Comunista Brasileiro - PCB - sobre o espaço estético-intelectual que, no caso da "Geração MAPA", ${ }^{24}$ Lina atribuía a um senso de classe pouco pedagógico. ${ }^{25}$ concretude de um veículo institucional,
IMG 79.

"A Intolerância", Crônicas de costume, de cultura da vida, de arte, de história 7, Diário de Notícias (19 de out. de 1958).

\footnotetext{
24 A "Geração MAPA" integrava, entre outros Fernando da Rocha Peres, Paulo Gil Soares, Calazans Neto e Glauber Rocha.

25 Cf. Lina Bo Bardi, "A Intolerancia [sic]”, Crônicas de costume, de cultura da vida, de arte, de

história 7, Diário de Notícias (19 de out. de 1958). Ver também "Resposta", Crônicas de arte, de

história, de costumes, de cultura da vida 8, Diário de Notícias (26 de out de 1958).
} 


\section{RESPOSTA}

Os jovens de MAPA ficaram maguados com nosso "grifo" de domingo. Mas nós falamos da UNIVEESIDADE, como base da grande cultura (como foi a de Paris, Bolonha, Padua, Wonipellier) e não do "predio" da Universi.dade.

Da cultura que serve e da que não serve e que îấconsola o homem. Pareee mesmo ter havido um equivoco de linguagem. Falamos nos termos de critica construtiva e não das "verbas". Achamos nosso dever ético apontar o lado crítico perigosamente limitado, diriamos pequeno burguês de um certo tipo de cultura. A cultura do inteiectical literato, sem finalidade a cill. iura que faliu em duas giterras mundiais $e$ que se jor mantida em vida, ainda nos levará a uma terceira $E^{\prime}$ a cultura anti-sputnik. Um conto, uma novela, que nos foi enuado certa vez, ilustrado com xiogravuras (Reserva com orientacáo tipográfica especificrda), tem um conteído bem difierente da revista 'mportante é entender-se claramente", (BERTHOLT BRECHT, "DER IASAGER"). Somente assim poder-se-á compreender se se combate do mesmo lado - RED

Ciente de que havia tura resposta ao nosso "grifo" de domingo, recusada por outro orgâo de imprensa, solicitamos a sua publicaçüo em nossa página. Como nos chegou tarde, vai publicada na segunda página do primeiro caderno desta ediçâo.

IMG 80.

"Resposta", Crônicas de arte, de história,

de costumes, de

cultura da vida 8

Diário de Notícias (26

de out. de 1958).

Em Contribuição Propedêutica, entregue no ano anterior de suas atividades na tribuna da imprensa de Salvador, Lina já sinalizava que "vida quotidiana acompanhada pelo arquiteto através da crônica de jornais [poderia] sugerir o estudo da realidade de novos problemas" ${ }^{26}$

Lina seria responsável, além dos textos principais do suplemento, das sessões fixas: "Antologia", sessão análaga à Correspondências, em Habitat, nas cartas inventadas e ou reproduzidas em sua versão popular; "Documentos", constituindo um arquivo iconográfico de Salvador, que pontuava as questões da história que seriam desdobradas na outra sessão, "Olho sôbre a Bahia", ao relacionar cultura, planejamento urbano e patrimônio, a partir da noção de presente histórico, no valor de sua preexistência em acordo com a validades mediadas pelo tempo, "como fonte viva de contribuições reais". ${ }^{27}$ "Qual dos dois você escolheria?", apareceria em algumas edições, e discutiria os valores da cultura na formação dos critérios estéticos do ambiente modernizador que se propunha, aos moldes da sessão "Quale scegliereste?", da revista italiana $A$; assim como a sessão "Resposta", cujo espaço problematizava os assustos cuja recepção pública se mostrava polêmica. Por fim, uma ilustração, única sessão assinada - um ataque direto contra os excessos de uma burguesia provinciana, aos moldes $A$ e Alencastro.

26 Lina Bo Bardi, Contribuição Propedêutica ao Ensino da Teoria da Arquitetura, op.cit.,p.62.

27 Ibidem, p.39. 


\section{ANTOLOGIA}

\section{CARTA DO PAIS}

\section{DA SECA}

Vamos publicar nesta página de CRONICAS cartas, bilhetes tantos outros documentos da vida, nos quais encontramos vez cu outra a chama da alma popular. procurada muitas vezes em văc Felos escritores profissionais. 'Vảo 6 isto que vemos na carta abaixo, através do emaranhado saboroso da ortografia, a humanidade transpirando em cada linha?

Canudos. 20-8-58.

Saudacois eadiane

A Amada irmon Jarmi adove Adous minha querida irmeón di todo o mou coraçĭo Jarmi vai eate adeus de longi viaitar minha querida irmon por prova di amor grandi amisadi Jarmi e eom us olhos raxes di lagrima que pogo na minha amavel pena para eserever esta delieiosa Cartinha

- li dozer que entamos com asude - li comunicar a nossa querida v 6 falicida faleceu no dia 6 deste estou muito tristi mas Deus e di noa Consolar Jarmi aque eatar - bom chuvido graxas ar bom Deua Jarmi a terra da genti que tinha linpa era meia tarefa Ja plantemos mas o feijăo eutar muito ruin com a friexa parbace que năo vai dar nada

Jarmi eu fiquei baatante axtis. foita di recober oun Cartinha di saber que voot ven en inneiro Jarmi fiquei moito alseri do De nheiro nosso eschora e venhor de Bon fin thi ajudi que moite me sirviu neste tompo jarmi eu nর̌xo pe cel di voce lenbrar de mim deate tanto jarmi quando voob mi esqrever esqreva al Coidsdos di ar. Joľo Aristidis di Molo o mais receba di todoe un aper. to de nŏo de paulo reocba bence de D. Ixabel vixitas de Dalva - de Commadro Maria un forte abrabo di tua irmáo boti a benas das meninae vou termina. con anudadis

Joetefa Maria da Coneeigho Keersva mi esnpri

IMG 81.

"Antologia".

Crônicas de arte, de história, de costumes, de cultura da vida 1, Diário de Notícias (7 de set. de 1958 


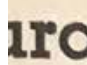
desligado

uma posi

i esta po.

como base

ia a is ci-

aliás, hoje

iscar Nie.

is formas.

a. evocaçăo

orviço dos

la humani-

ipre.

xiste, mas

resolvem,

esquecen:

definidos

como d

na pureza
oferimos.

a casinha

impuseram

onal, pela

isto. pob.

denunoiava

O homem

que Oscar
depoimento

indicando

- uma po-

a todos o
todas con

It nacional.

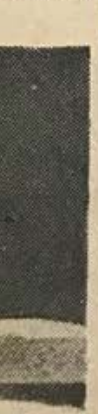

silia

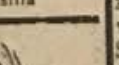

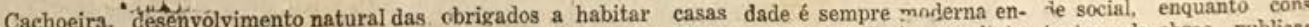
trimento natural das. cbrigados a habitar casas dade é sempre so jublicas, mas igual a tantas outras formas arquitetônicas, ur- e cidades nas quais serâo quanto atual. Ao arquiteto terrenos e capitais publicos, ruas desta Cidade do Sal- tanistieas, criadas pela ne- estrangeiros, as abandona- compete estuda-la e com- terrenos e capitabras exposvador e Cachoeira é ainda cessidade da vida cotidiana. ráo ou serāo transformados preendê-la e traduzi-la em zuer dizer de obto e á visSalvador e uma cidade não $\mathrm{O}$ projetista que olha as numa humanidade amorfa. formas modernas e eficien- as ao juigamento que pôr na nenhum compartimento sevistas de arquitetura. sen. aem desejos e sem perso tes, 0 homem, a mulhes. an de todos, tem que por na estanque, ramifica-se, cres- tado na prancheta e não tem nalidaide. 0 arcuiteto de que passam nesta rua, têm cão năo o individualismo for c6. cria galhos, folhas e raizes e devagar sai dos alhos para a reas materiais e espiri- cia de ser útil aos h`mens, confins e torna-se adulta un criador de edificos resultados das obtidas pela bua A propris case e os por meio de sua art: e de (a) expressâo verdadeira significac to da rificador tem que basear que existe somente na sua ou nada. A significaça cl. máxima de responsabilid, o. seu projeto sobre este fantasia e os homens reais intima da vida de uma cl.

\section{Problematica da Arte Moderna}

23

Q ${ }^{0}$ inst

B.

\section{Texto e desenho de Mario Cravo Jr.}

A atmontera saturada e her. cáo. Entáo véem os monatron

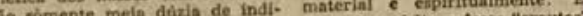

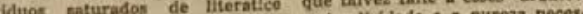

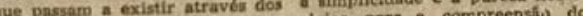

baskes Torra carioca salo

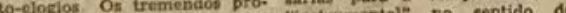
blemas do nosso século al estió, tinstrumental no sentido
vlvos, palpltantes, enquanto a ferramentas do nosao eiculo

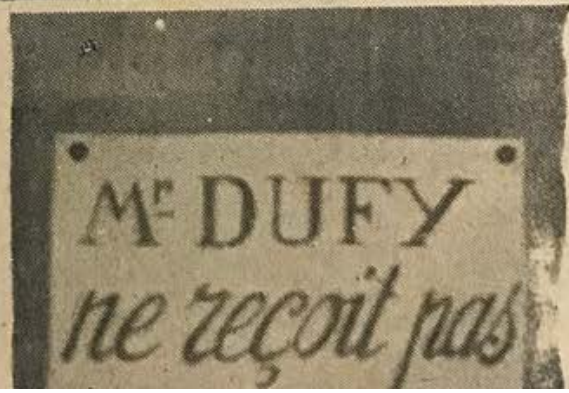

Turris Eburnea!

\section{Or. Dufy năo recebe ninguém.} E' uma defesa contra as senheras gráfinas, diletantes de arte ou um ato de soberba? Talvex os dois, pintor Dufy, pintor da Cóte DAzur e do Sweepstake taivez năo gostasse da sociedado. Talvez náo gostatio de pseudo. hit tistas intelectuais. Talvez olhas. se antes de abrir, por um bura. e especial da perta, a cara de edinte. Mas este cartióo do lema do artista do hoje, conhecido, publicado, celebrado,

IMG 82

"Olho sobre a Bahia".

Crônicas de arte, de

história, de costumes

de cultura da vida

2, Diário de Notícias

(14 de set. de 1958). 


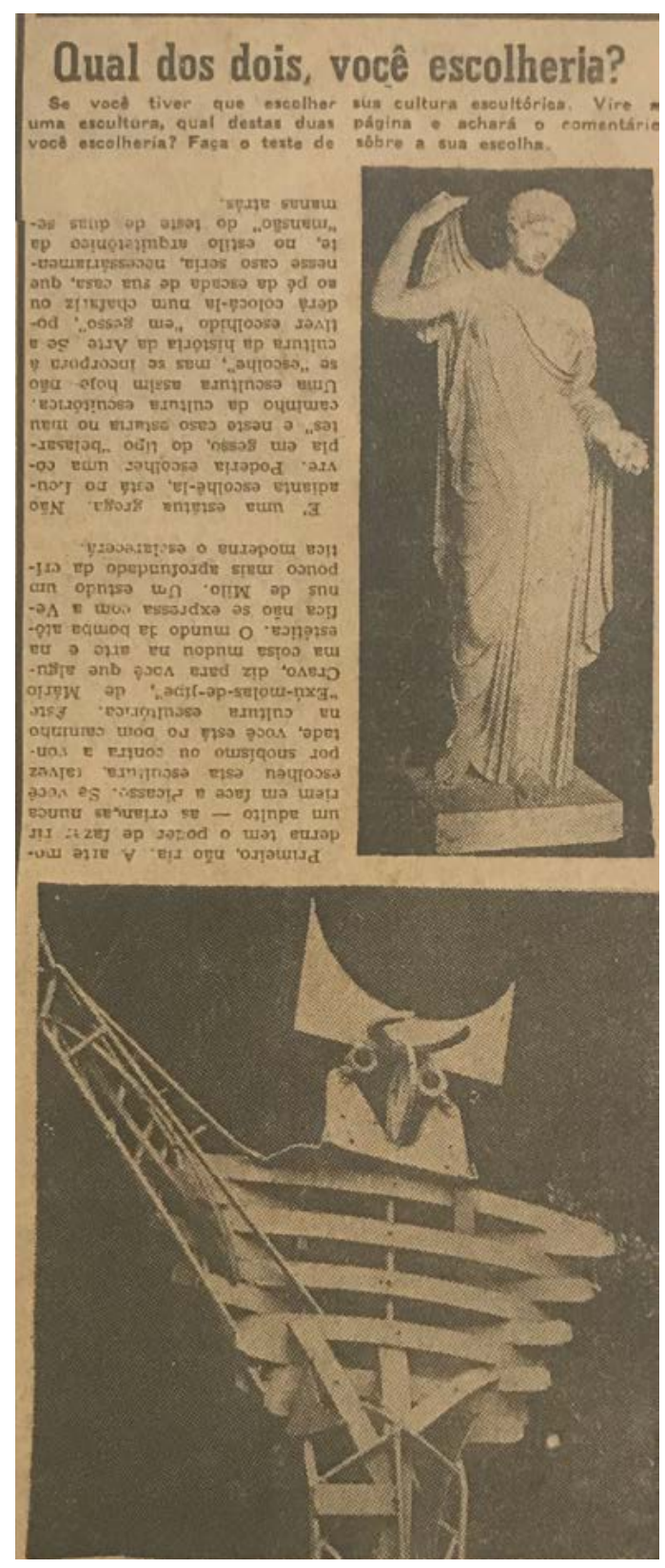

\section{IMG 83.}

"Qual dos dois você escolheria?" Crônicas de arte, de história de costumes, de cultura da vida 8

Diário de Notícias (26 de out. de 1958).

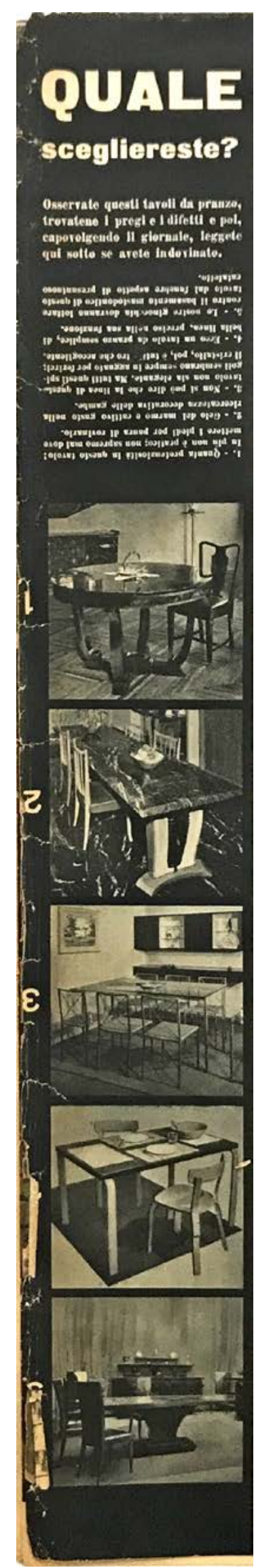

IMG 84.

Quale scegliereste?.

[Revista A n.4, abr., 1946]. 


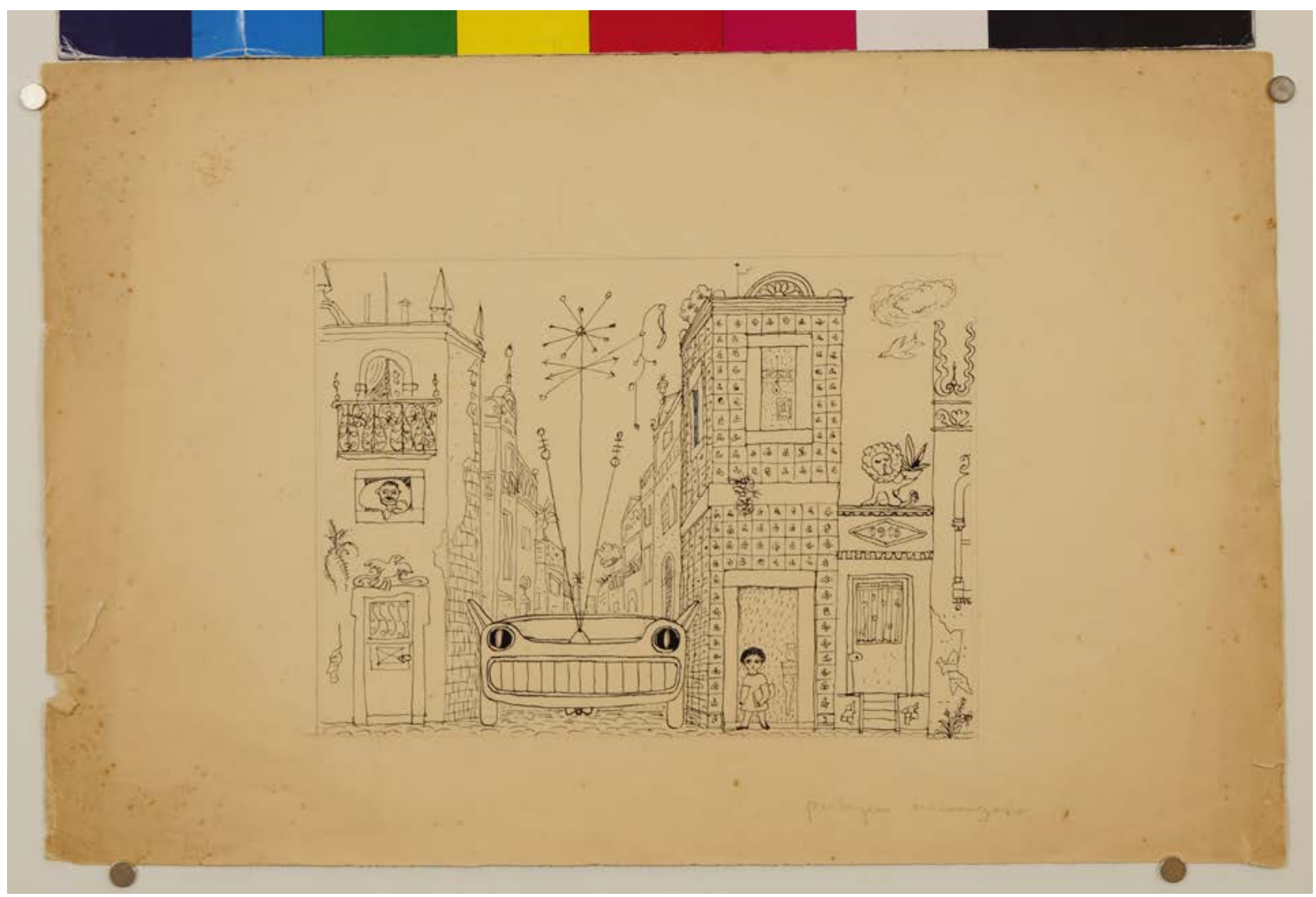

IMG 85.

Tarde mecanizada. Crônicas de arte, de história, de costumes, de cultura da vida 1, Diário de Notícias (7 de set. de 1958). Arquivo ILBPMB. 


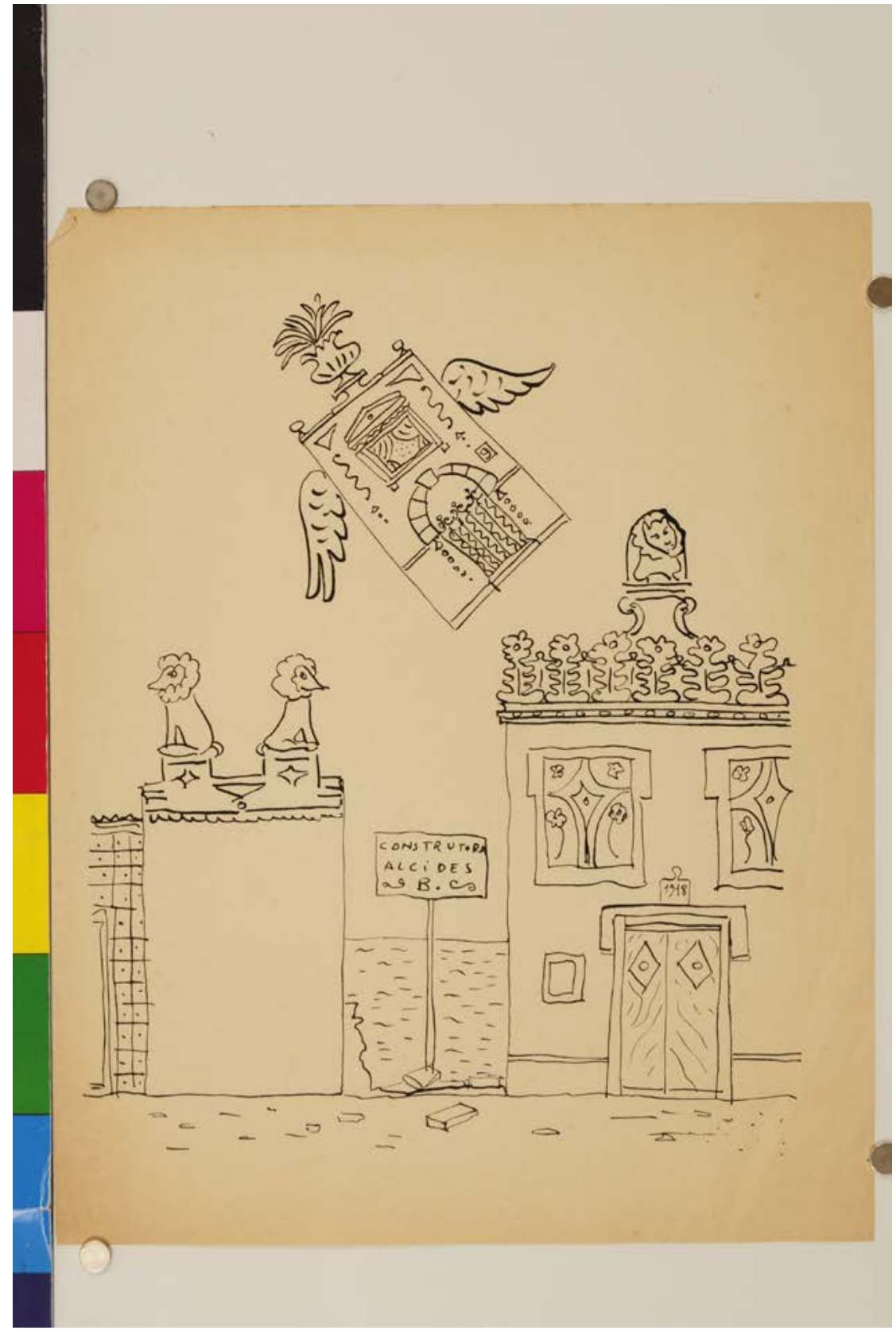

IMG 86.

Noturno. Crônicas de arte, de história, de costumes, de cultura da vida 3, Diário de

Notícias (21 de set. de 1958). Arquivo ILBPMB. 


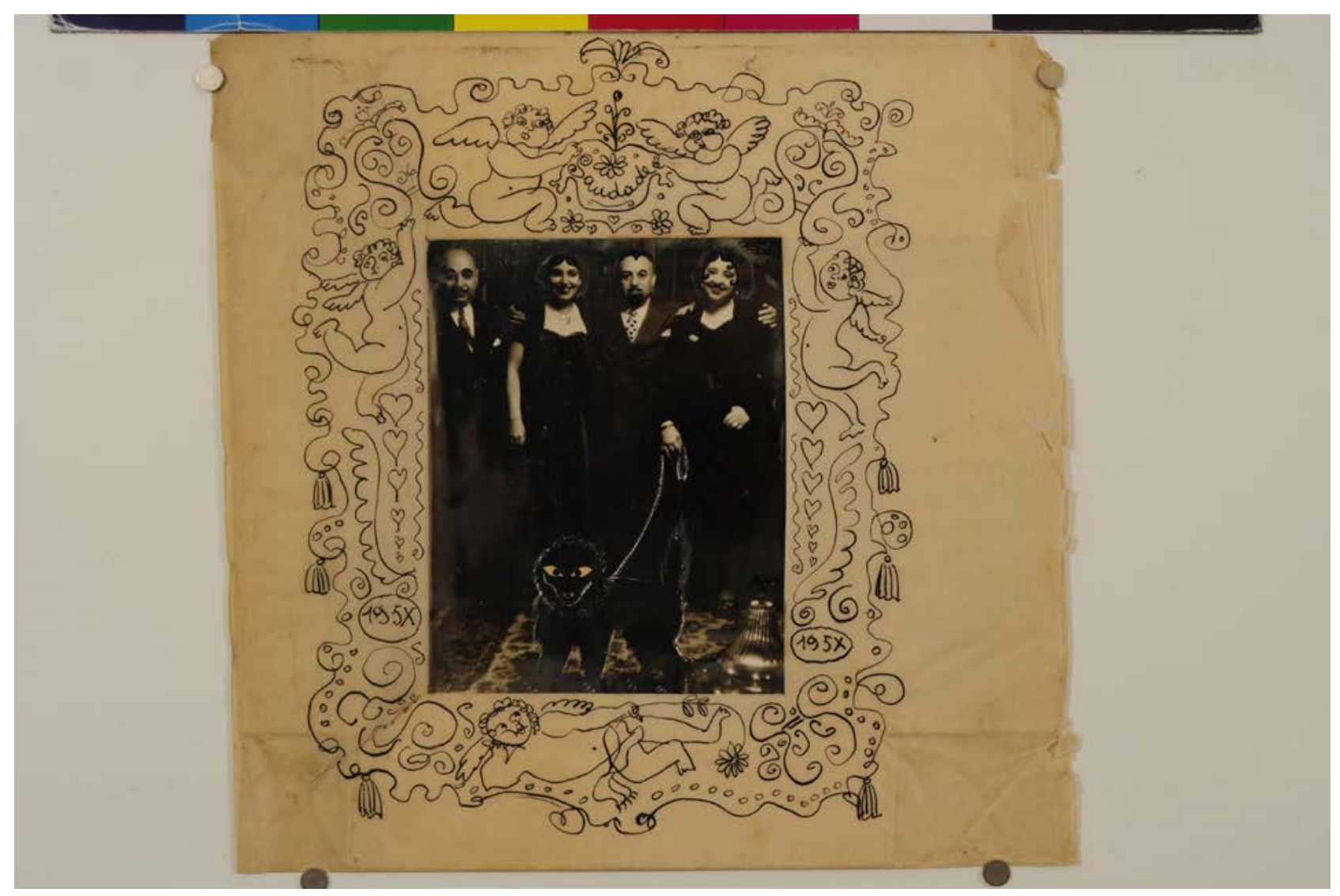

IMG 87.

Retrato de família. Crônicas de arte, de história, de costumes, de cultura

da vida 5, Diário de Notícias (5 de out. de 1958). Arquivo ILBPMB. 
IMG 88.

Paisagem. Crônicas de arte, de história, de costumes, de cultura da vida 6, Diário de

Notícias (12 de out. de 1958). Arquivo ILBPMB.

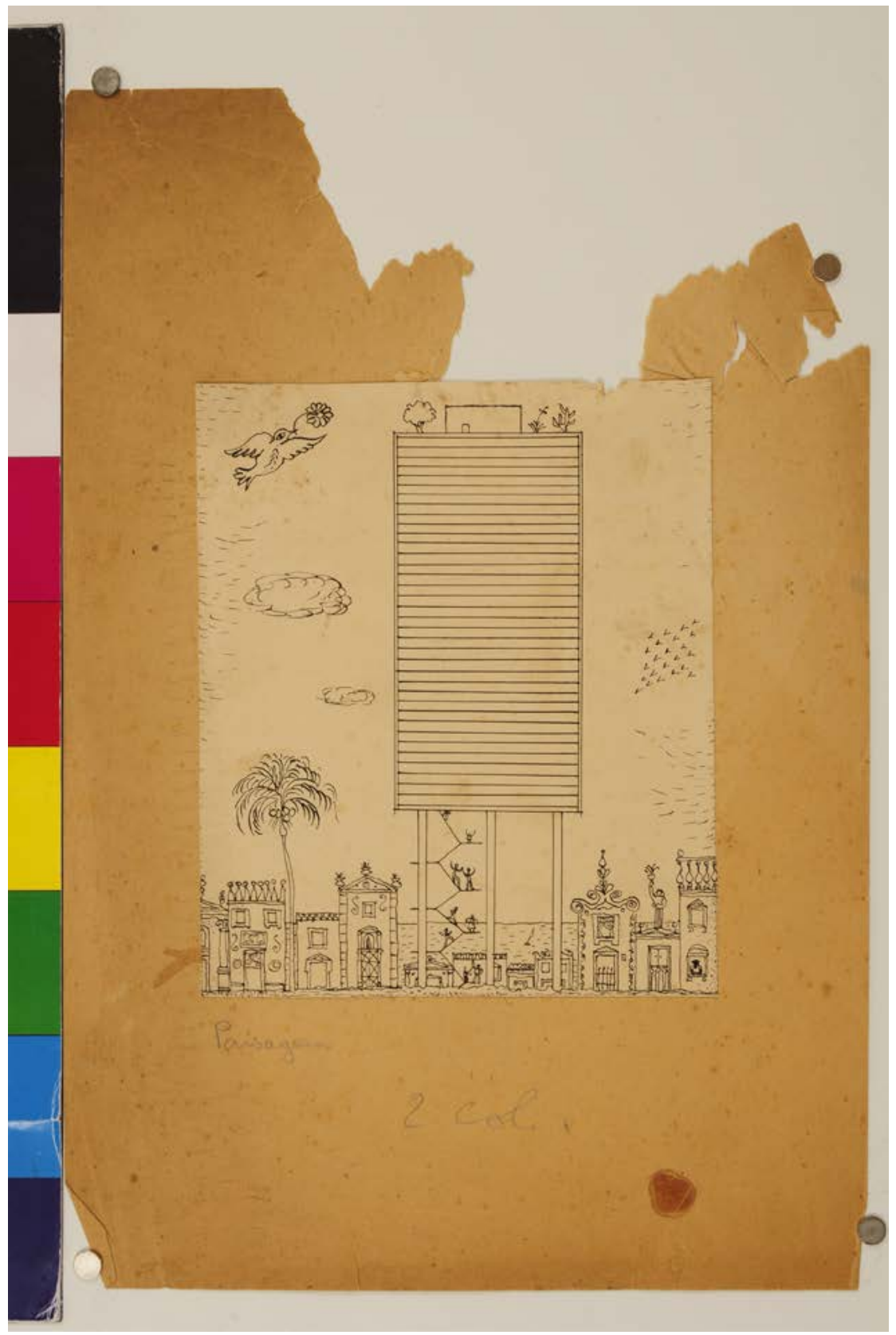


IMG 89.

Interior. Crônicas de arte, de história, de costumes, de cultura da

vida 7, Diário de Notícias (19 de out. de 1958). Arquivo ILBPMB.

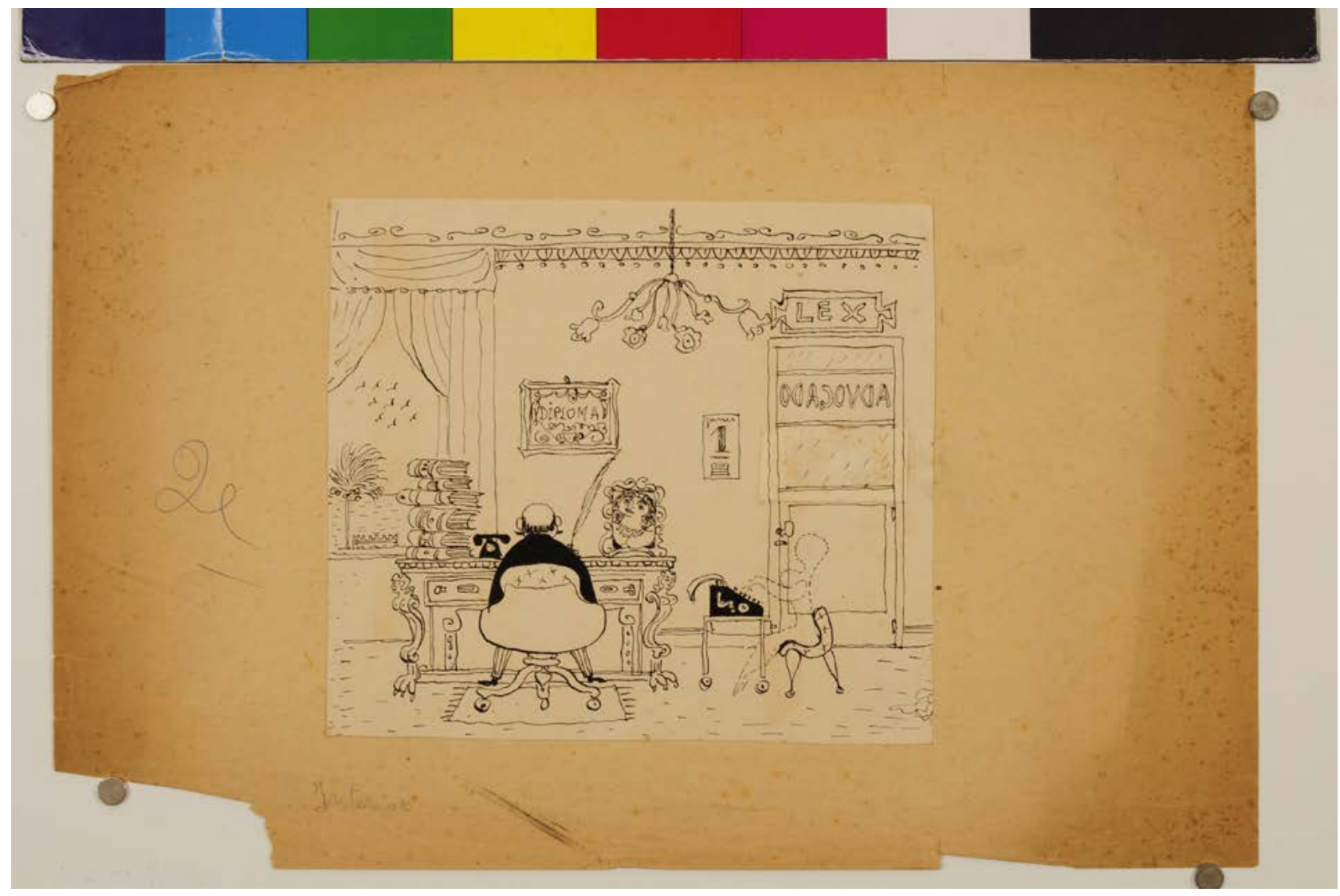




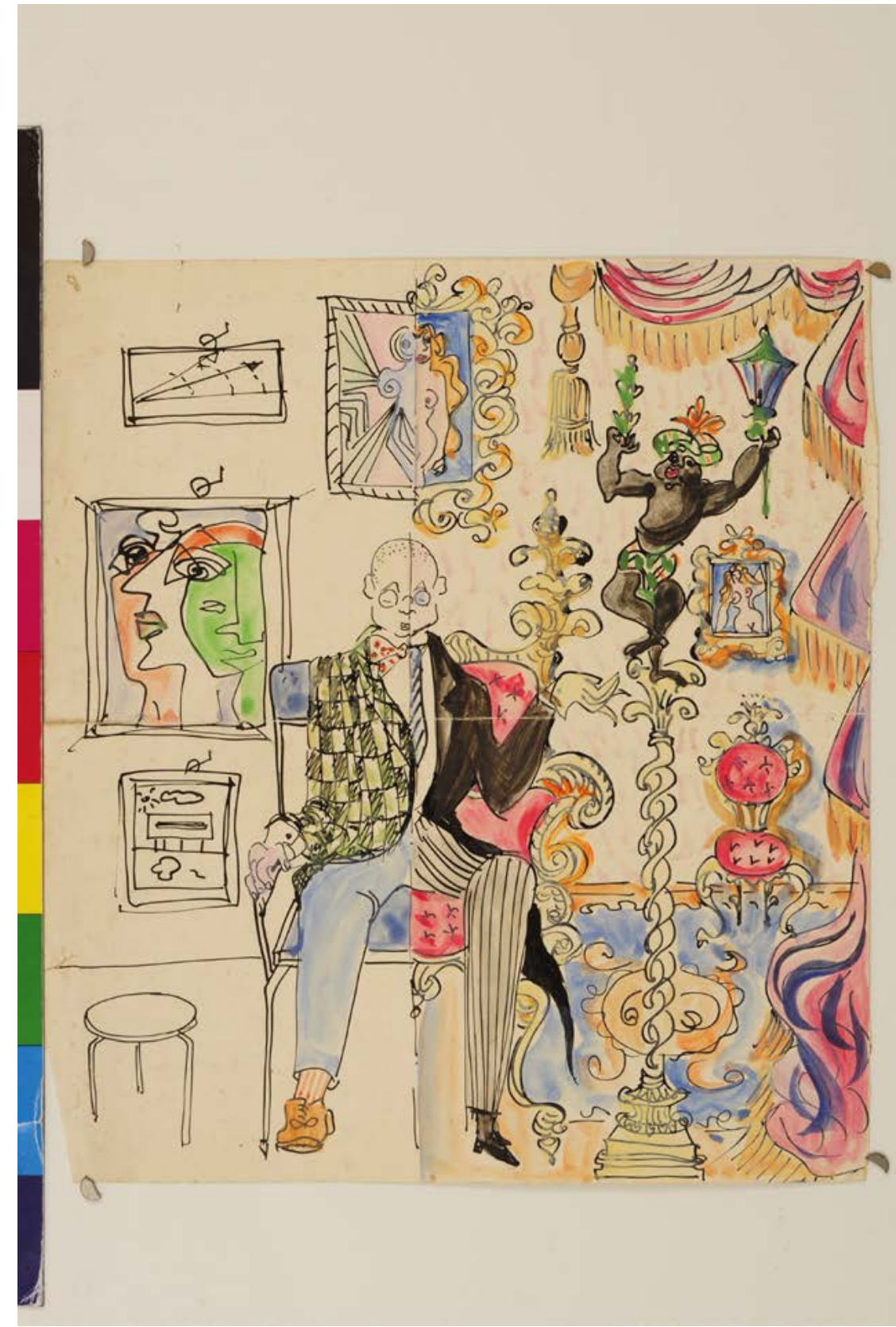

IMG 90.

Desenho para

Crônicas, etc.

Arquivo ILBPMB 
A crônica principal "da arte, de história, de costume, de cultura da vida", realizava uma síntese construtiva dos temas atravessados na práxis de Lina e dos quais, evidentemente, ensejava a participação pública. Inaugural, o texto - "Cultura e não cultura" - denunciaria os desdobramentos da "cultura útil ao homem" em direção a uma "pseudo-cultura" e suas implicações frente a uma maioria assolada pelas necessidades da existência, reivindicando "uma ação política efetiva", a "parte dos homens assediada pelos problemas econômicos", cuja "força latente (...) [de] uma forma primordial de civilização primitiva (não no sentido de ingênua, e sim composta de elementos essenciais, reais e concretos), coincide com as formas mais avançadas do pensamento moderno". ${ }^{28}$

No segundo número, "arquitetura ou Arquitetura", ${ }^{29}$ apontaria a falta de correspondência entre o "Depoimento" ${ }^{30}$ de Oscar Niemeyer e sua prática profissional no Museu de Arte Moderna de Caracas e em Brasília, cujos aspectos formais foram privilegiados em detrimento da responsabilidade social da prática da arquitetura. "Mas o que é arquitetura senão o meio mais eficaz para combater com o exemplo a mesma injustiça social [...] que tanto o feria?, Lina perguntaria, num compromisso de reflexão crítica que não a impediria de defender Brasília, às críticas de Zevi, anos mais tarde. ${ }^{31}$

Em "Inatualidade da Cultura", ${ }^{32}$ no terceiro número, diante da destruição do Convento do Carmo, no Rio de Janeiro, comunidado por "telegrama lacônico", Lina indaga: "por que então a impremsa não se ocupa, com mais assiduidade dos problemas de arquitetura, da arte, de todas as artes?", ressaltando que ao usar o adjetivo 'velho' ao invés de 'antigo', revelaria toda crise de nossa época: "o cheiro de mofo da cultura abandonada a si mesma".

28 Crônicas de arte, de história, de costumes, de cultura da vida 1, Diário de Notícias (7 de set. de 1958).

29 Crônicas de arte, de história, de costumes, de cultura da vida 2, Diário de Notícias (14 de set. de 1958).

30 Oscar Niemeyer. "Depoimento". Módulo n. 9

31 L'ARCHITETTURA - CRONACHE E STORIA, n.109, Milão, Nov. 1964, pp. 436-37

32 Crônicas de arte, de história, de costumes, de cultura da vida 3, Diário de Notícias (21 de set. de 1958). 


\section{Inatualidade da Cultura}

Um telegrama lacônico trans- derna ainđa nẫo utilizou êste mitiu ao público que, domingo meio poderoso: a propagande passado, o Convento do Carmo para os fins desinteressados da do Rio de Janeiro era destruido cultura, em favor das grandes pelo fogo, inclusive a sua pre- questỏes culturas: a construçăo ciosa biblioteca de dez mil vo- de um Edifício de uso coletivo, lumes. O comunicado foi publi- as grandes Exposiçōes de Artes cado nos vespertinos, modesta- Plásticas, os Congressos, os Fsmente, ao lado das grandes man- petáculos, continuam sendo mochetes relativas aos fatos inter- nopólio dos poucos eleitos e a nacionais, aos acontecimentos po- massa está excluida e continua liticos e ao noticiário policial. na ignoráncia a respeito da arte.

Por que a um suicídio, um O Convento do Carmo do Rio desastre, uma declaração políti- de Janeiro está destruido com ca se dá tanto relevo enquanto sua biblioteca. Um novo lacôniassunto de cultura é relegado a co telegrama diz dois dias deplano secundário, ou mesmo năo pois que será construido um nomencionado?

vo convento moderno, munido

Por que entảo a imprensa nāo de elevadores para substituír se ocupa, com mais assiduidade velho edifício. Nesse adjetivo dos problemas de arquitetura, da velho, usado, ao invés de antigo, arte, de tôdas as artes? Não é a está tôda crise de nossa época: construçấo de um Mercado, um o cheiro de mofo da cultura Teatro, uma Escola, um aconte- abandonada a si mesma, do ancimento público, de interésse ge- tigo năo querido e nầo revivid. ral imediato? Um projeto de ar- mas sim mumificado e esquecido

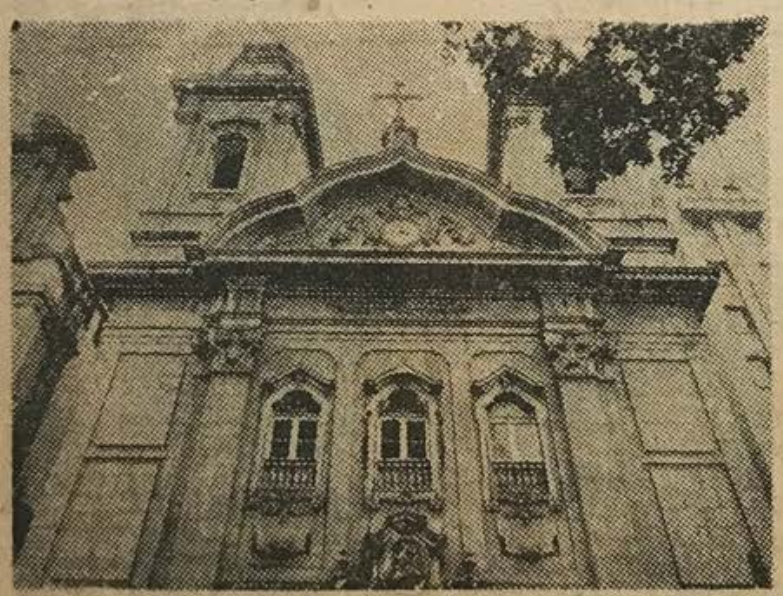

Detalhe da fachada da Igreja da Ordem Terceira de N. S. do Carmo no Rlo do Janeiro

quitetura divulgado em tempo Quem construirá o novo convenútil, nos seus detailhes técnícos, to do Carmo? Quem será o arplantas, cortes, poderia provocar quiteto? Quando surgir a nova discussóes e polêmicas construti- construçāo, sob a indiferença gevas e muito danos poderiam ser ral, o público poderá ver no luevitados. Poder-se-ia objetar que gar da antiga, uma arquitetura falta no público a consciência eem época, anônima, e ao obsercritice e a vador saudoso do antigo edifício mento e conseiente de uma ocasiāo permento, mas esta consciéncia crí- dida para uma construçáo vertica necessita ser criada e ali- dadeiramente moderna, será talmentada, e até que os problemas vez a única consolaçăo aquílo de caltura sajam relegacon nas vez a única consolaçăo aquílo

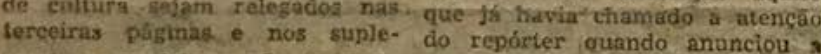
mentos especinis e nsio entrosa- nova construça: "O Convento dos no noticiário cotidiano, de do Carmo e sua biblioteca foram público interêsse, a maioria dos destruidos: em seu lugar tereleitores continuará ignorando és. mos um prédio novo com elevates problemas. A civilizaçăo mo- dores".

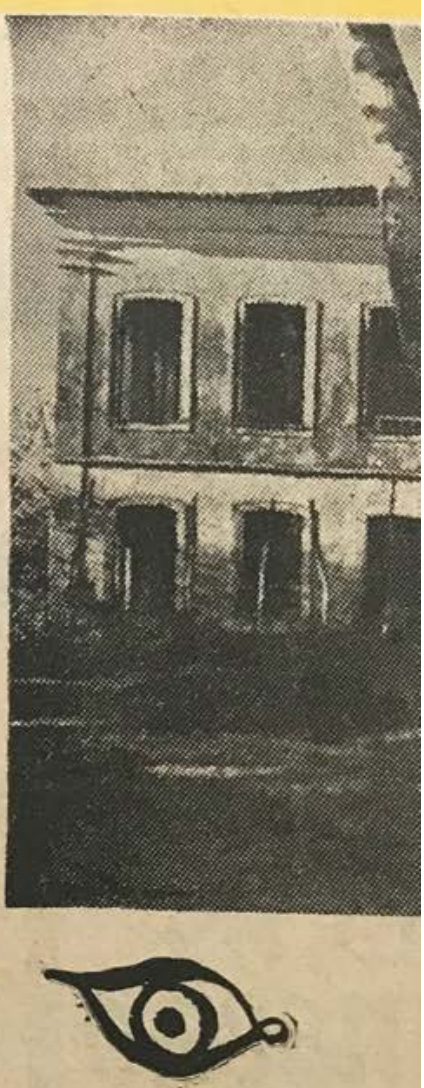

Engenho Sao José da g Vila de São Francisco. h A conservação de um mo. e numento antigo não signifi. ca a conservação de uma vitrina de museu, mas a inte.

\section{ACUSAÇ̃̃O E DEFESA}

PROFESSOR

TECNICO-CRITICO

TERCEIRO HOMEM

ANONMO

PROF. - Por que publicaran artigo de Mario Cravo? Li tuuo com mixita ntençio e não compreendi nada; a certo mo. mento, virei-o ao contrário para ver se o compreendia melhor. Aliás tinha uma linha de cahe. a para balxo.

TEC.-CRIT. - Sim, tinha, un cliché. A culpa è do emnon. ascior e do pasinador

PROF, - E um artigo incont creensivel e pleonastico. Estas colsas todo mundo sabe, Esta nova geraçấa toma tudo a sčio dezais, falta de espirito, perdeu o "sense of humour". Isto é muito grave.

TEC.-CRIT. - O senhor è no. mem do século XVIII, um "honnête homme", como se dizla na quele tempo, e impiedoso.

PROF. - Nảo compreendo es-

tas involuçôes enfátices. Eu sou
IMG 91.

"Inatualidade da Cultura". Crônicas de arte, de história de costumes, de cultura da vida 3 Diário de Notícias (21 de set. de 1958). 


\section{A Escola e a}

Vida

A Uniăo Brasileira de Fecritores dersunciou squilo que de finiu como um atentado á cultu ra, á liberdade democratica e á liberdade de pensamento, por parte de uma comissâo de "censura", nomeada pelo diretor da Faculdade de Filosofia da Universidade do Paraná e que teria climinado da biblioteca daquel escola alguns autores julgados
Les, Yata consciencia, este espitho coletivo de colaboracho tem que existir desde a escola, que deveria opor a regra, que é a mesma da sociedade, "cada um por si" á regra "um por todos todos por um". A igualdade de todos os cidadáos em face à instrução, a obrigaḉć de uma educaçáo igual para todos até ponto erucial da escolha da pro- antitese da vida tem que ser a propria vida. Entre a escola e a vida năo pode haver soluçăo de continuidade. Sobre uma escols obrigatoria, igual para todos que yá até os limites da especialisaç̃o, que seja preparo à vida, criando o costume da auto-disclplina frelectual e da autonomia moral, e em que se baseia esperança do novo humanismo

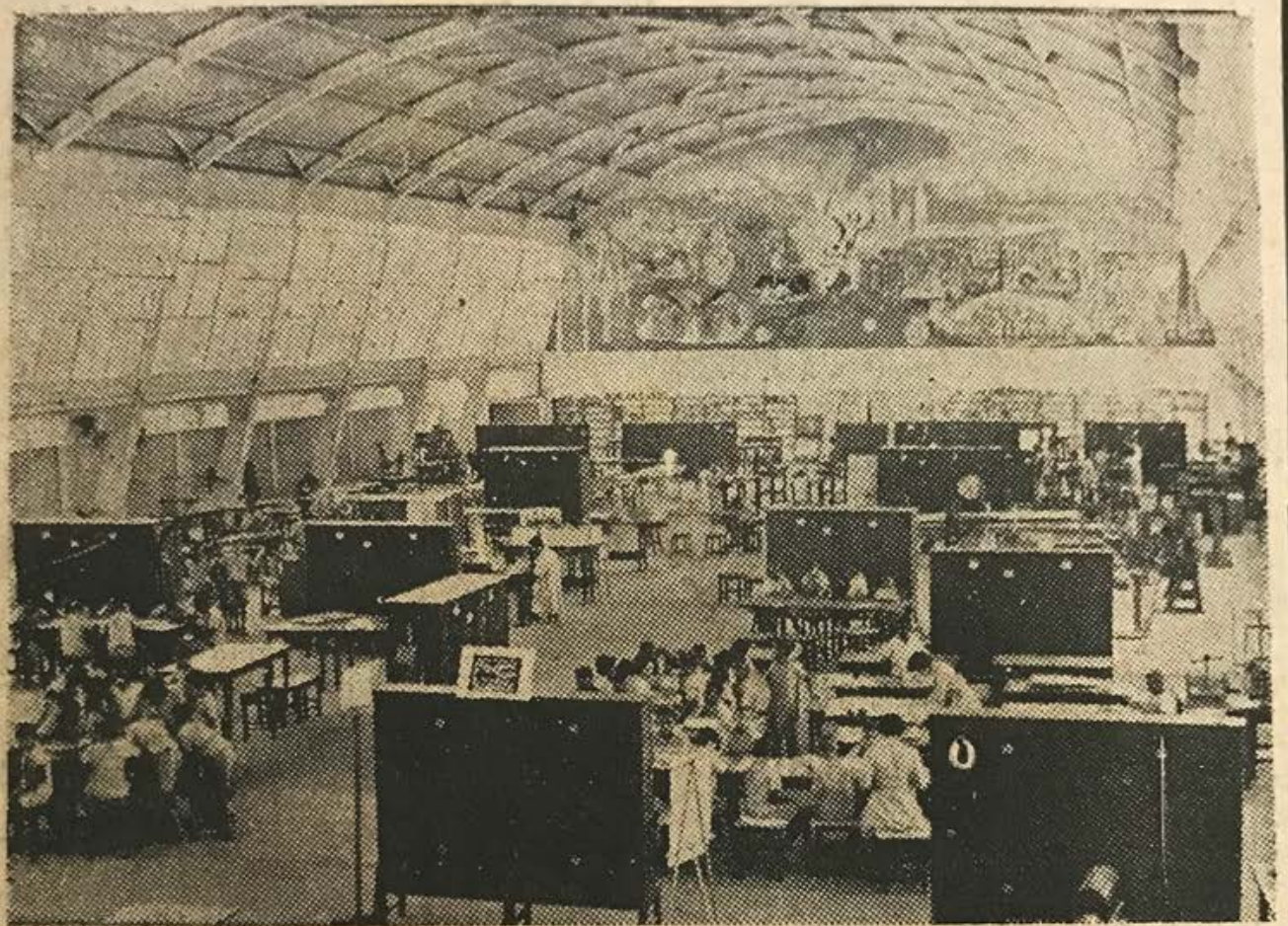

Vista da seçâo masculina da Escola Carneiro Ribeiro (arquitetura do Diogenes Rebouças) que deu soluçäo ao problema basico do trabalho coletivo dos alunos projetando um grande ambiente mico que somente os moveis di videm idealmente as diversas seçñes. Anisio Teixeira, organizador tecnico do tipo da escola, realisou, nesto obra, o ideal do trabalho coletivo, como preparaéco espiritual, eliminando desde o comego os complexos individualistas.

mocivos i. juventude, entre os Quais Sartre, Eça de Queiroz, $\theta$ Jorge Amado e a obra do educa. dor Anislo Teixeira.

Dste ato, superando os limites das liberdades a da democracia. fustamente denursciado p e 1 a Uniăo Brasileira dos Escritores, atinge um problema bem mais grave e urgente: o da Fscola tundamento de constituiç̧⿸尸o de uma Nagăo formada por ódadhos responsaveis, verdadeiros colaboradores, criadores da vida democratica do País e năo crentos desinteressados num Estado abstrato que pensa e resolve por fissắ, seja irckelectual ou manual, é tarefa do Estado democratico, expressăo viva da coletividade. A funçăo do professor é essencial e responsavel do grau de civilizaçáo de uma nagăo. A formação de um corpo de educadores, conscio das proprias responsabilidades, acostumado ao trabalho de equipe, em luta rigorosa contra o diletantis. mo, à improvisaçăo, à soluçăo dos problemas por meio da "ora toria" e "declamaçăo", tem que ser a base da nova escola.

A escola é a cultura de um pais; a escola que se tornou a
Uma escola da coletividade, quer dizer do Estado, que proporcione a todos, indistintamente, o método criador pela clência e pela vida, método cuja comunicaçăo seja monopolio da Escola e não do acaso da vida prática.

Este é o sentido mais profundo do atentado da Universidade do Paraná. Um atentado à escola, à liberdade da escola: liberdade sem a qual, a Escola năo poderá se organisar na forma que uma nação democratica requer, forma que a escola anciosamente procura, e poderá ser retardada mas näo impedida. 
O texto "A Escola e a Vida" discute os limites do vínculo entre a Escola, ${ }^{33}$ enquanto instituição, e o Estado, em uma democracia, a partir de um ato de censura na Faculdade de Filosofia da Universidade do Paraná, onde três anos depois, já à frente do MAMB, Lina seria entrevistada para a III Semana Nacional de Estudantes de Filosofia. ${ }^{34}$ A Escola Carneiro Ribeiro, em Salvador, projeto-piloto de Anísio Teixeira, ilustra o texto, cujas trocas frutificariam, na ocasião do Projeto da Escola de Desenho Industrial e Artesanato integrada ao Solar do Unhão.
IMG 93.

III Semana Nacional de Estudantes de Filosofia, 1960. Arquivo MAMB

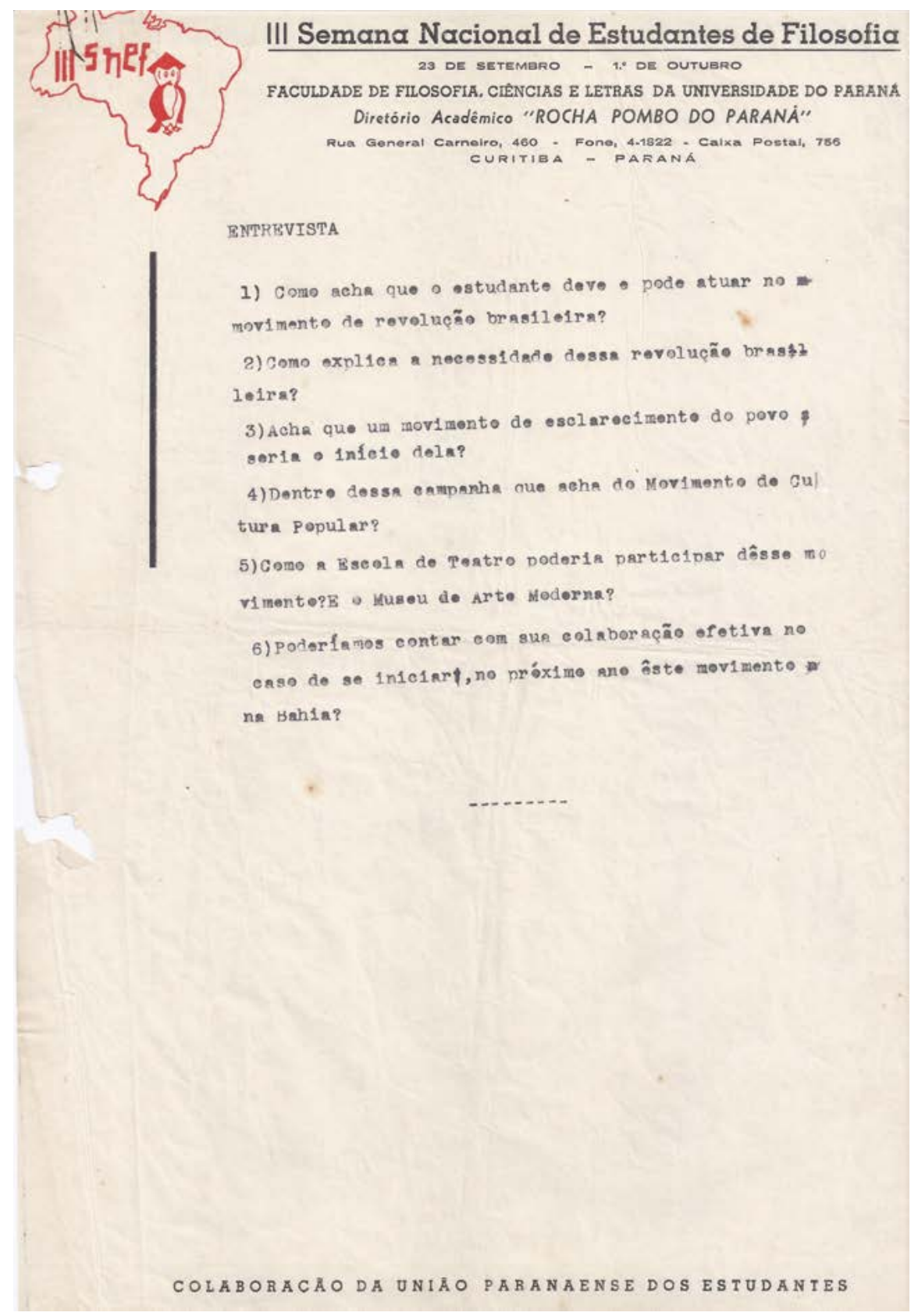

MG 92.

"A Escola e a Vida". Crônicas de arte, de história, de costumes, de cultura da vida 3, Diário de Notícias (21 de set. de 1958). 


\section{EMVRIVISTA:}

1) Como acha que o estudante deve e pode atuar no movimento de revolução brasileirgh?

Se com a palavra revolução quer se apontar a imprescindí vel necessidade histórica, para o Pals se constituir numa en tidade autonoma, auto-suficiente economicamente e capaź de contribuir com carateres destacadamente nacionais e válidos na cultura feeterel) internacional, acho dever dos estudantes se constituir inediatamente num orgão capaz de agir diretamen te como regulador duma verdadeira revoluça cultural. Para isto \& necessário que os estudantes adquiram a maturidade e a auto-disciplina intelectual e a autonomia moral necessárias a constituição dum verdadeira Novo Humanismo. Bsclareģo que com a palavra đultura quero definir o conjunto dos problemas exig tenciais do homem modemo, problemas imprescindiveis das bases econômicas, e não a "cultura" munificada dos manuais desligados dos problemas da vida prática.

2) Como explica a necessidade dessa revolução brasileira?

A necessidade duma revolução econômico-cultural ế a reąlida de histórica, hoje, de todos os paises de formação colonial, e a reinvindicação do direito dos homens a viver mume plenitude realmente humana, dentro das reais possibilidades criadas pelo trabalho do proprio homem e fora dos mitos. Com a palavra "colonial" não quero definir apenas as "colonias" politicas, mas também toda forma de suficiencia e paternalismo economico e cultural tipico da civilizaça de tipo exclusivamente ocidental e mediterrêneo que pré dominou atế hoje.

3 ) Acha que um movimento de esclarecimento do powo seria o inf cio dela?

A verdadeira democzącia não pode prescindir do "esclarecimentoInopular", mas precisa imediatamente dar ao povo a capaci dade, os "instrumentos" para poder participar ativamente na lu ta pela cultura nacional: o analfabetiamo o abandono cultural são terrenos proprios para uma forma de "paternalismo", paliativo que näo pode corresponder às necessidades dum país verdadeiranente autonomo. 
4) Dentro dessa campanha que acha do llovimento de Cultura Populax?

Uma verdadeira cultura nasce sempre de rafzes populares. Cultura Popular assin como \& definida comumente no sentido da divulgagão "vulgarizada" ou dum aproveitamento folklorico be um equifroco que rebalxa as classes populares, detentoras tambén duma cultura que tem que ser aproveitadas pelos intelectu ais numa base de mítua troca sem a impafia tipica da cultura dos intelectuais sub-descnvolvidos.

5) Como a Escola de Teatro poderia participar dêsse movimento? B O lluseu de Arte Loderna?

A Escola de Teatro e o lluseu de Arte Iloderna poden contimuar participando do movimento de autonomia cultural nacional, como fizeram até hoje. Hos para que o resultado seja aproveitado pre cisa libertar os orgão de propaganda e as tribunas públicas,dos crfticos improvisados e dos "interessados pessoalmente" e fazer uma campanha de esclarecimento dos verdadeiros valores culturais modernos. Sem esta premissa honesta, sem una honesta colocag̃o dos valores, o trabalho mais "eficiente" num sentido atual o na cional corre o risco de ser aviltado e reduzido a um episbaio $\underline{1}$ solado e de conisequência inútil aos fins coletivos.

6) Poderfamos contar com sua colaboragão efetiva no caso de se iniciax, no próximo ano êste movimento na Bahia?

o linseu de Arte Hoderna já procurou iniciar, com sua função didática, êste movimento. 


\section{Crônicas \\ de arte, de \\ Arte industrial}

Eiz-se hoje umá cerla contu- veis. O problema é outro.
nijo entre artesanato niso entre artesanato, artecio, ar. problema urgente que derivs bteratura (ná, Euiste tóda uma justamente do tim da era artebteratura (nắo queriamos ukar a sanait: a cisūo entre téentco-e palavra retorica) - esto respei- operário executor

10, 0 que $e ́$ artesanato? $\mathrm{A}, \mathrm{ex}$ - $\mathrm{O}$ arquiteto que projeta um prezsio de um tempo e de uma edifleio náo convive com o pesociedade, un trnbalhador que dreiro, o carpinteiro, ou o ferpossui um cppital mesmo modes. teiro. O desenhisto de objeto to. Que the permita trabalhar a dométicos, com a ceramista, tuateria prima e vender o pro- vidraceiro. O desenhista de móduto acabado, com lucro materiel e satisfaça cspiritual sencto - objeto projetadio e executado por éle mesmo. O que de artesio, hojet 2 um executor un expeciarista sem caplial, que empres. ta O proprio serviço a quem a ele torpece a materia prina, seja dono ou cliente, $\mathrm{e}$ recebe um salario en troea de proprio trabatho de execucáo. E o assim coumardo proietário.

Que o a arte popular, quanda verdadeira? $E$ arte, com $\Lambda$ matuscalo

Qual zeria a pergunta justa para uma valida resposta? Evjdentemente, a seguinte: existe uma razáo eficiente que justifique as injeçes oticials a cite pacudo arvessnato is Evidentemen. ts, náo. Porque nesse modo tiravo a artesio a tazáo mesona de rer, a satistaçás de poder criar um por contu própria, O dese- objeto ertisticamento o ser nhista técnico tem complexo do matcrialmente o proprietario inferioridade pela ausèneia de deste objeto e, em seguida, o seu competencla pratica. O operario vendedor, 0 problema urzente executor 6 avilado pela falta de - gravissimo do conhecimento Eatiśagta etica do proprio trado oficio e a ratistaçáa morar balho. O assunto central poderia decivada do trabalho Lỉo con- ser colocido na base da colheita fundiasas com o artesanato A tmediata de todo $c$ material arItain, a Espanha e Portugal dis, tesanal amtigo e moderno exis tinguiram to nesto protecionisma lente $\mathrm{cm}$ cads pain, na criaçán paternalistico que originou os de um grande museu vivo, um
vírtos "purblos" vários "purblos" espanhois a museu que poderia so chamar de "Inatitut diarte ortigianali", ver. Artesanato e Arte Induatrial, e dadeiros muscus' de horrores e que constltulsse a raiz da cultu-
catalosos de especies inominá- ra hlitb́rico-popular do pajs,
Este Museu deveria ser carnpletado por uma escola de arto industrial (arte no sentido de oticio, além de arte) que permidesenhistantacto entre tacnicos expressasse, no sentido moderpu aquilo que foi a artesanato preparando novas levas năo pro futuras utopias, mas para a realidade que existe e que todo3 conhecem: o arquiteto de pranch que desconhece realidade da obra, o operárío que náo sabo "ler" uma planta, o desenhtsta de móvels que projeta urna cadeira de madeira com as caraeteristicas do ferro, o tipografo que compōe mecanicamente som conhecer as leis elementares da composiçẩo tipografifica e nssim por diante. Os primeiro fora da realidade e dentro da teoria, o outros, amargurados pelo trabstho mecánico de soldar unia peca, apertar uma porca, sem corhecer o tim do proprlo traba tho.

N5io queremos assim desvalorlzar a obra do eluda ofvalorgrupos artesanais. Ecsa ajuda uma transigäo, uma fase de siçáo necessária encuanto trantista popular e artiste purar simplesmente e ntie pode sotre Intluéncias dirigidas. pode sotre

A nossa é uma ́poca coletiva Ao trabalho do artesâo-dono substitui-se o trabalho de equipe - os homens têm que estar pre parados para esta colaboração. proj distingajo hierarquica entes projotistas e executantes. Somente assim, poder-se-d voltar a folicidado de uma participacáo paral a uma obra. Uma partici. pagá coletiva, nú mais indivi. cual; o resultado técnico do artesanato dos nossos días: a indústria.
IMG 94.

"Arte industrial".

Crônicas de arte

de história, de

costumes, de cultura

da vida 8, Diário

de Notícias (26 de

out. de 1958).

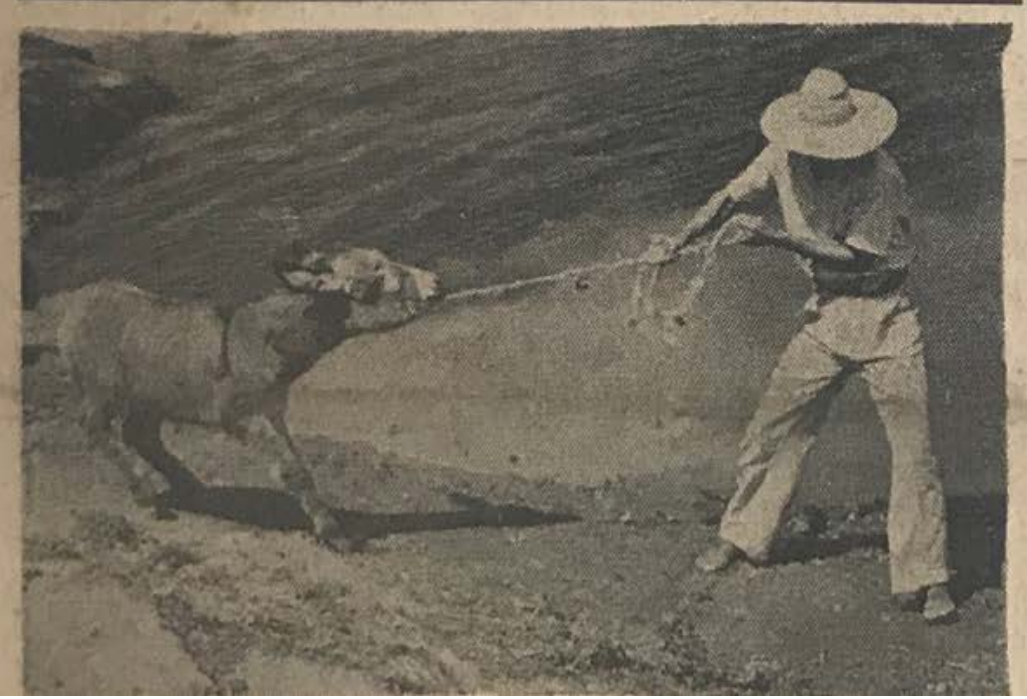


No quinto número, o artigo "Casas ou Museus" retoma a discussão da função social dos museus, amplamente debatida nas página de Habitat, enquanto espaços didáticos e sua necessária veiculação com a cidade, para além de um local de conservação, mas como equipamento público, alicerçado sobre uma base técnica-didátida do museu moderno, uma vez que um "museu petrificado [...] é inteiramente inútil" ". ${ }^{35}$

O texto "A Invasão" ", ${ }^{36}$ denunciaria e papel do poder público na crise da habitação popular no Brasil, apontando para necessária implementação de um plano técnico, não como filantropia, mas como um direito de todos, pontuando referências do período entre guerras. Já em "A lua", ${ }^{37}$ diante de "uma profunda cisão existe entre o progresso técnico cientítico e a capacidade humana de pensar", Lina sinalizaria o hiato entre os avanços tecnológicos e a cultura, que incidem sobre "este homem moderno, ainda culturalmente antigo."

Por fim, em "Arte Industrial", ${ }_{38}$ apareceriam as primeiras reflexões sobre a necessidade de um museu ligado à arte popular, "arte, com A maiúsculo", a partir da precisão dos termos artesanato, artesão e artista popular. Consonante ao passado produtivo do complexo do Unhão, a ideia de formalizar um lugar onde fosse possível operacionalizar a passagem do pré-artesanato ao desenho industrial começava a ser delineada.

35 Crônicas de arte, de história, de costumes, de cultura da vida 5, Diário de Notícias (5 de out. de 1958).

36 Crônicas de arte, de história, de costumes, de cultura da vida 6, Diário de Notícias (12 de out. de 1958).

37 Crônicas de arte, de história, de costumes, de cultura da vida 7, Diário de Notícias (19 de out. de 1958).

38 Diários de Notícias, n.8 
"E' nosso proposito, realmente, abrir o comercio do Brasil a to. das as Naçóes do mundo. 0 ministro Lafer já está tratando do assunto. A ele, portanto, deveria ser feita a pergunta", respondeu ontem o presidente Jus. celino Kubitschek, nos Campos Eliseos, a um jornalista, depois de uma conferencia a portas fechadas, com o governador do Estado, durante cerca de $20 \mathrm{mi}$ nutos.

O chefe da Nação chegou aos Campos Eliseos ás 20 horas e 10, após ter presidido á cerimonia de inauguração da $\mathrm{V}$ Bienal de S. Paulo, no Ibirapuera, e ter pronunciado um discurso de cinco laudas dactilografadas.

0 presidente chegara ás 17 ho. ras e 50. No "Viscount" presidencial vieram também os ministros do Exterior, sr. Horacio Lafer, e da Aeronautica, brig. Correa de Melo. Aguardavam-no na pista o governador e o vicegovernador. Nos recintos do paviIhão oficial, estavam as demais autoridades, inclusive deputados estaduais do PSD, que chegaram ao aeroporto no momento em que 0 avião presidencial tocava a pista. O lider da maioria, de. putado Abelardo Jurema, e outros parlamentares federais haviam chegado em outro aviăo e esperavam o presidente. 0 prefeito não compareceu nem se fez representar.

IMG 95.

O Estado de

São Paulo, 22 de set., 1959 . 


\title{
Políticas públicas e subdesenvolvimento
}

\begin{abstract}
O Brasil, voltado até então para o mar, teria de assumir uma atitude diametralmente inversa, isto é, voltar as costas para o oceano e empenhar-se em tomar posse efetiva do seu território, de cuja existência só tinha conhecimento através dos mapas. ${ }^{39}$ (KUBITSCHEK, 1975).
\end{abstract}

Intrínseco ao apogeu do projeto nacional-desenvolvimentista, cujo mote de aceleração intensificou o desenvolvimento dos centros urbanos do Sudeste - estágio resultante de séculos nas cidades europeias, lembraria Lina - , ${ }^{40}$ foi também responsável pelo aumento progressivo das desigualdades regionais.

Preterido da geografia industrial imposta pela agenda do governo, no Nordeste se acentuava a movimentação política dos trabalhadores rurais a quem, paulatinamente se associavam os movimentos operário urbano e estudantil, acenando para uma intensificação dos movimentos sociais tanto no meio rural, com as Ligas Camponesas, quanto no urbano, com a Frente do Recife."

Diante da insatisfação de camponeses e

39 KUBITSCHEK, Juscelino. Por que construí Brasília. Rio de Janeiro: Bloch Editores S.A., 1975, p.12

40 Lina Bo Bardi, "Um balanço dezesseis anos depois", em Tempos de Grossura: o design no impasse, ed. Marcelo Suzuki (São Paulo: Instituto Lina Bo e PM Bardi, 1994), 11.

41 Diante da grande mobilização popular do início dos anos 1960, ganha força o projeto "nacional-popular", pautado na idealização da figura do povo brasileiro consonante às forças sociais consideradas capazes de promover a revolução nacional. Ver Ferreira Gullar. Cultura posta em questão. Rio de Janeiro : Editôra Civilização Brasileira, 1965. 
operários, a Revolução Cubana [1956-59] despontava como um bem-sucedido movimento revolucionário latino-americano, fazendo da questão nordestina um problema de segurança nacional:

[...] zonas subdesenvolvidas são zonas potencialmente ocupadas pelo inimigo [regime soviético]. Não pertence ao Brasil o que está dominado pela fome, não se acham efetivamente integradas no organismo nacional as áreas em que as populações vegetam no isolamento ou são dizimadas pela precariedade das condições de existência. 42 (KUBITSCHECK, 1959).

Nesse contexto de desenvolvimento, em que o Estado assume uma postura de indutor do desenvolvimento em amplo espectro, por meio de um projeto modernizador para além do setor industrial, importante considerar os organismos paralelos de desenvolvimento ligados ao Poder Executivo, seja na implementação da política econômica, seja na racionalização administrativa. Nesse escopo estaria a atuação do economista Celso Furtado na Superintendência do Desenvolvimento do Nordeste (SUDENE), que lhe permitiu colocar a problemática teórica do mundo industrial no campo das políticas públicas, cujos objetivos convergiam em desenvolver o Nordeste brasileiro, especialmente no que se referia à indústria e ao artesanato local.

Impulsionada pela grande seca que assolou o Nordeste em 1958, a SUDENE emergia "[...] num momento em que se revelaram de modo particularmente aberto e intenso os antagonismos da sociedade do Nordeste". ${ }^{43}$

Os gastos exponenciais com a construção de Brasília levariam a um crescente processo inflacionário em 1959, intensificando o ruído na euforia nacional-desenvolvimentista, veiculada por JK. Nesse cenário se elege presidente, em 03 de outubro de 1960, Jânio Quadros e, seu vice, João Goulart. A renúncia de Jânio e o deslocamento para um nacionalismo encabeçado por João Goulart agravaria a crise, acentuando a polarização ideológica da sociedade que, no âmbito da esquerda, se daria sob as bases de um nacionalismo reformista, cuja ideia síntese seria a de "um povo-nação em luta contra o capital estrangeiro"."

Na busca da superação acelerada dos problemas estruturais, sucediam-se estudos econômicos cujas análises defendiam uma industrialização pelo Estado, como alternativa de desviar os países latino-americanos de seu atraso iminente frente às potências econômicas mundiais. ${ }^{45}$ Nesse cenário de disputas político-ideológicas importante destacar as ações do Instituto Superior de Estudos Brasileiros (ISEB), na organização de uma intelligentsia orquestrada sob o nacionalismo na produção de conhecimento sobre a realidade brasileira, com o objetivo de aumentar a consciência nacional e popular, a partir da consagração do Estado como mecanismo centralizador da economia, nos moldes da teoria cepalina, ao pensar os problemas-chave da relação entre industrialização e desenvolvimento. ${ }^{46}$

42 Trecho do discurso do presidente na aprovação da lei de criação da SUDENE, em www.adene.gov.br, acessado em 20/12/2018.

43 IANNI, O. "As Ligas Camponesas e a criação da SUDENE". Em Origens agrárias do Estado brasileiro. São Paulo, Brasiliense, 1984, p.210.

44 Fausto, Boris. História do Brasil. São Paulo: Edusp, 2000, p.350.

45 Os estudos foram desenvolvidos entre os anos de 1950 e 1960, pela Cepal [Comissão Econômica para a América Latina] e de seu correspondente nacional, o Iseb [Instituto Superior de Estudos Brasileiros].

46 A CEPAL/Comissão Econômica para a América Latina, foi criada pelas Nações Unidas em 1948, com sede em Santiago do Chile, a partir da teoria do economista argentino Raul Prebisch. 




\section{Soyons artistes, nous le pouvons}

Na passagem dos anos 1950 para os anos 1960, a ideia de trilhar um caminho baseado na ideia de 'substituição de importações' era um tema central tanto para a teoria estética quanto para as teorias econômicas progressistas. Os economistas ligados à 'teoria da dependência' pensavam um caminho parecido com os saltos de desenvolvimento que a vida econômica da América Latina podia dar no contexto do surto desenvolvimentista. No mesmo ano em que Hélio Oiticica fazia sua transição do quadro fixo para o espaço/tempo, a arte na vida, Celso Furtado publicava seu influente (não apenas no Brasil) estudo sobre a dependência econômica, o sentido de nosso 'atraso' e os impasses de nosso (sub) desenvolvimento, a Formação Econômica do Brasil. Não apenas desenvolvimentistas também queriam a superação da dependência em nome da autonomia nacional criadora. Foi também em 1959 que Antonio Candido tratou de reunir a experiência intelectual acumulada nas ciências sociais, na sistematização universitária da prática acadêmica renovada da USP e no ensaísmo literário brasileiro, e publicou seu trabalho seminal, "Formação da Literatura Brasileira". Ou que, nas telas dos cinemas e cineclubes, os jovens cineastas que inauguravam o Cinema Novo

47 O catálogo da exposição Bahia começa com as frases de Lautréamont: "La poésie doit être faite par tous, non par un" e termina com Adolph Appia: "Soyons artistes, nous le pouvons", validando a produção popular enquanto manifestação artística. 


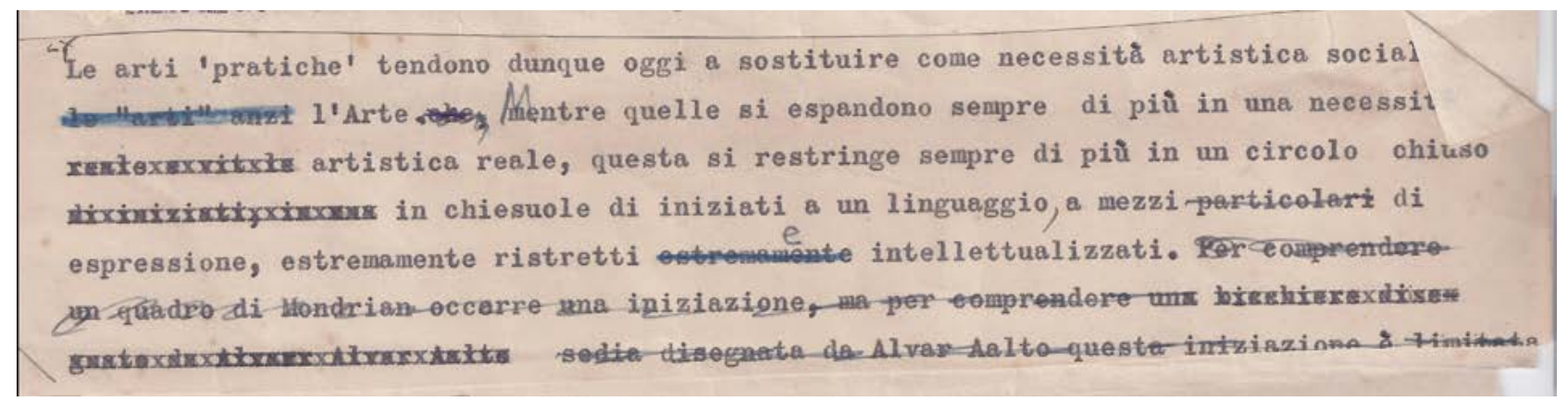

IMG 96.

Rascunho

Artes Menores,

1960. Arquivo

MAMB. elaboravam as imagens da "fome" e da situação do mundo "subdesenvolvido", com sua luz particular, articuladas com diversas linguagens tomadas da vanguarda cinematográfica pós-guerra-48

As pesquisas pelo Nordeste seriam a base das exposições-manifestos realizadas por Lina. A primeira delas, a exposição "Bahia", ${ }^{49}$ cuja curadoria dividiria com o diretor de teatro Martim Gonçalves, se apresentaria paralelamente à V Bienal de São Paulo, em 1959.

No mesmo ano em que o projeto de Sudene tomava corpo como projeto que, ao pensar a industrialização do Nordeste colocava em xeque os desmandos da "indústria da seca", entendendo a complexidade do semiárido brasileiro muito além da irrigação, cujo "oásis onde se repetiria o milagre da multiplicação [seriam] frutos do trabalho humano". ${ }^{50}$ Nesse contexto, sob a marquise do Ibirapuera, Lina chamava atenção para "a região pobre mais extensa do Hemisfério Ocidental". ." $^{\text {. }}$

Evidente que suas ações, naquele momento, estão alinhadas com a teorias cepalinas e produzem reflexões críticas centradas na interdependência entre centro e periferia. A questão do subdesenvolvimento para esse grupo de teóricos derivados de Prebisch, trazem à tona a consciência de um tipo de desenvolvimento que, antes de ser um estágio a ser superado, revelava sua necessária condição subdesenvolvida para a manutenção de desigualdades que se equilibravam no contexto da divisão internacional do trabalho. Em outras palavras, o subdesenvolvimento, só seria superado, no horizonte de uma revolução democrática. Para Celso Furtado:

Poucos de nós estamos cientes da natureza profundamente anti-humana do subdesenvolvimento. Quando entendemos isso, facilmente explicamos porque as massas estão dispostas a tudo para superá-lo. ${ }^{52}$

Apesar de financiada pela V Bienal de Arte de São Paulo, a exposição Bahia aconteceria como evento correlato à mostra construtiva inicial, ${ }^{53}$ e permaneceu aberta ao público entre 21 de setembro e 31 de dezembro de 1959.54 A preocupação de Lina em desvincular-se do programa principal da Bienal estava relacionada à

48 Francisco Alambert. As bienais de São Paulo da era do museu era dos curadores. São Paulo: Boitempo, 2006: 229-230.

49 Por exposições-manifestos entendemos as exposições: Bahia no lbirapuera [1959], na V Bienal de São Paulo; Nordeste e Artistas do Nordeste[1963] e A mão do povo brasileiro [1969], que inauguram, respectivamente, o Museu de Arte Popular do Unhão e a nova sede do MASP na Avenida Paulista.

50 "[...] Saí em passeio pelo meu sertão de origem, em plena estação seca, e dei asas à fantasia, antecipando a transfiguração daquelas terras ásperas mediante a proliferação de oásis onde se repetiria o milagre da multiplicação dos frutos do trabalho humano. É caminhando à noite, sob o céu estrelado, que o sertanejo se deixa arrebatar pelo orgulho de sua terra. Os ventos que prolongam os alísios avançam céleres pelo horizonte aberto, e o mundo inteiro parece estar ao alcance da vista." FURTADO, Celso. A Fantasia Desfeita. São Paulo, Paz e Terra, 1997, p.132.

51 Celso Furtado. A Pré-Revolução Brasileira. Rio de Janeiro: Fundo de Cultura, 1962, p. 56.

52 Celso Furtado, A Pré-Revolução Brasileira, op. cit. 23.

53 Pedido de Lina Bo Bardi ao diretor da Bienal Ciccillo Matarazzo Sobrinha em carta, datada 13/03/1959. Arquivo Lina Bo e PM Bardi.

$54 \mathrm{Na}$ ficha técnica da exposição constariam os seguintes nomes. Da Bahia: Carlos Vasconcelos Maia (diretor do Departamento de Turismo da Cidade de Salvador), Magalhães Neto, diretor do Instituto Histórico e Geográfico da Bahia), José Augusto Azevedo (Escola de Teatro da Bahia), Ennes Mello (estudante da Faculdade Nacional de Arquitetura). De São Paulo: Edmundo Monteiro (diretor das Emissoras Associadas de São Paulo). Luiz Sadaki Hossaka (Museu de Arte de São Paulo). 

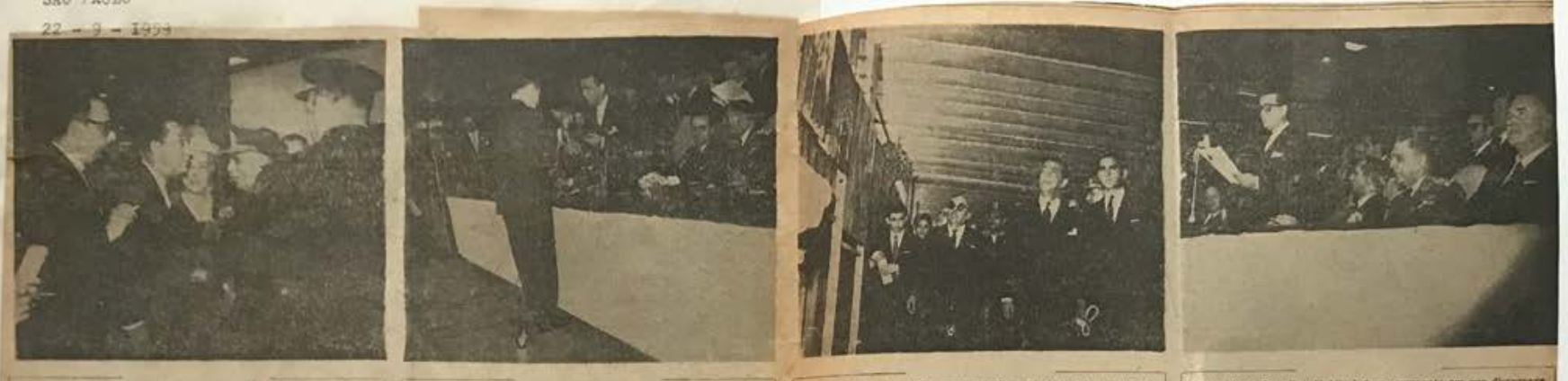

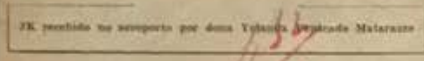

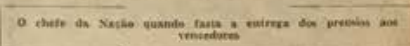

2 MIL PESSOAS NO PAVILHÃO

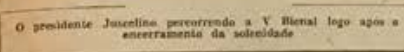

"ARMANDO ARRUDA PEREIRA"

\section{MARA VILHADO, JK INAUGUROU A V BIENAL DE ARTES PLÁSTICAS}

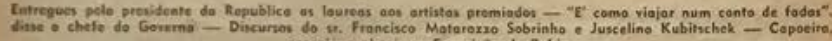

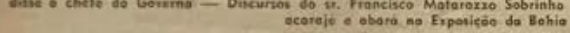
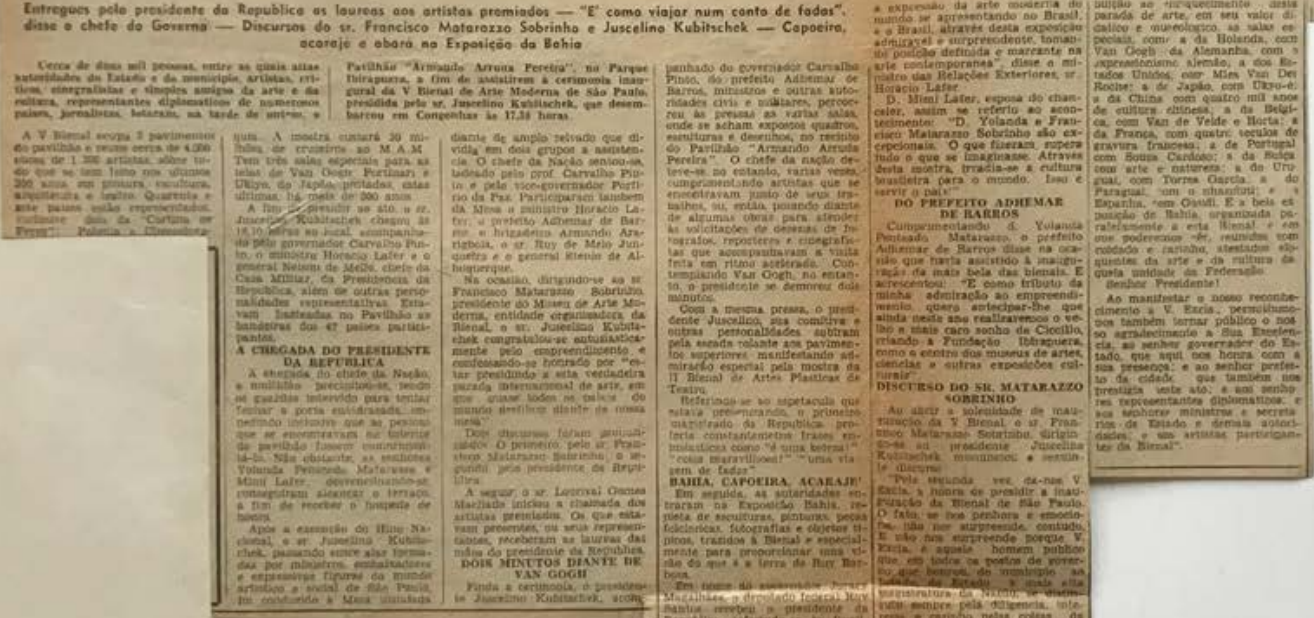

uma atitude de afirmação da arte popular como "ponto crítico na arte moderna". ${ }^{.5}$ Neste confronto com a parcela mínima da população detentora do juízo da arte, estaria a reivindicação da exemplaridade da arte popular, cujo conceito de cultura colocava a experiência cotidiana de seu povo como chave válida num sistema engendrado por uma visão paternalista do folclore.

55 Carta de Lina Bo Bardi a Eros Martim Gonçalves e registrada em São Paulo, 18 de jul. de 1959. Arquivo do Instituto Lina Bo e do PM Bardi.

IMG 97.

Diario da Noite, 22 de set., 1959 
A exposição Bahia lançava mão do saber acumulado sobre a realidade nordestina adquirido nos trabalhos que manteve à frente do MASP e, sobretudo, à revista Habitat, inclusive realizando a exposição "Artistas da Bahia", ${ }^{56}$ dois anos antes na instituição paulista.

A associação entre Martim Gonçalves e Lina Bo Bardi resultaria na na atmosfera dramática e, de certa forma, teatral, na ocupação dos espaços da marquise. ${ }^{57}$ No chão forrado por folhas de eucaliptos, uma cortina delimitaria o perímetro da exposição com a combinação de alguns planos físicos. De chegada, a escultura do orixá $E x u$ mola de Jeep. ${ }^{58} \mathrm{Na}$ atmosfera recriada pelas fotos de Marcel Gautherot, Silvio Robato, Ennes Mello e Pierre Verger - o "criador avançado da antropologia da vida cotidiana"; ${ }^{59}$ além de músicas afro-brasileiras e especialidades gastronômicas e mesmo uma performance de capoeira. Os paineis de exposição, por sua vez, estariam pintados ou cobertos de folhas de ouro: colchas de retalhos, coleções de ex-votos, flores de papel, esculturas africanas e roupas ritualísticas de candomblé, disseminando as raízes negras da cultura popular brasileira.

Sob a marquise, mais do que legitimar o estatuto moderno da produção nordestina, Lina abriria o campo para discutir a integridade dos valores éticos que então associava a arte popular. Mas, se sua agenda didádica primava pela equidade entre as artes, desfazendo sua atribuição entre maiores e menores, num esforço de validação da cultura material em todos os seus níveis de expressão, como recolocar, nesse escopo pedagógico, o atributo popular ao estatuto da palavra arte? Faz-se necessário, portanto, entender, o que está colocado em questão no universo da palavra popular. E nesse adjetivo de clara orientação política, antevemos que Lina estava menos preocupada em

56 Cf. Sante Scaldaferri, Os Primórdios da Arte Moderna na Bahia, op. cit., 78.

57 Enquanto Martim coordenava a captação das obras na Escola de Teatro da Universidade da Bahia, Lina ficaria a cargo de sua organização in loco.

58 Mário Cravo Júnior. Exu mola de Jeep. Ferro pintado, 350×250 cm, 1953. Doada pelo artista para o acervo MAM-SP, no Ibirapuera.

59 Descrição de Vivaldo da Costa Lima sobre o trabalho de Verger. Ligne de fuite, Vídeo produzido por Anne Papillaut - Vídeo/CNRS AV., 21 min., França, 1985.

\section{CAPOEIRA E ACARAJE'}

A' Bienal, o sr. Juscelino Kubl. tschek chegara ás 18 horas e 15. Depois de percorrer rapidamente a mostra de quadros, esculturas e cenarios teatrais, visitara a exposição da Bahia, instalada ao lado da Bienal, assistira a uma demonstraçào especial de capoeira e comera acarajés servidos ao lado da exposiçăo por duas baianas em trajes tipicos. Elogiara sorridente a iniciativa da Bahia e disse que ia mandar Minas Ge. rais fazer propaganda semelhante. Dali, ás 19 horas e 50 , partira para o Palacio dos Campos Eliseos.

Ali, esquivando-se de qualquer contacto com a imprensa, subia, funtamente com o governador Carvalho Pinto, para os aposentos que lhe estavam reservados, onde se preparou para o banquete em sua homenagem, no Joquei Clube de S. Paulo. Depois de vestir o traje a rigor, o presidente Kubitschek tomou um uisque com o general Nelson de Mello, que o acompanhava, o governador do Estado e alguns auxiliares diretos do governador, no "hall" do andar superior do Palacio.

A's 20 horas e 45 , retirou-se com o governador para uma sala, onde permaneceu 20 minutos. Eram 21 horas 45 quando o

IMG 98.

O Estado de São Paulo,

22 de set., 1959 . 

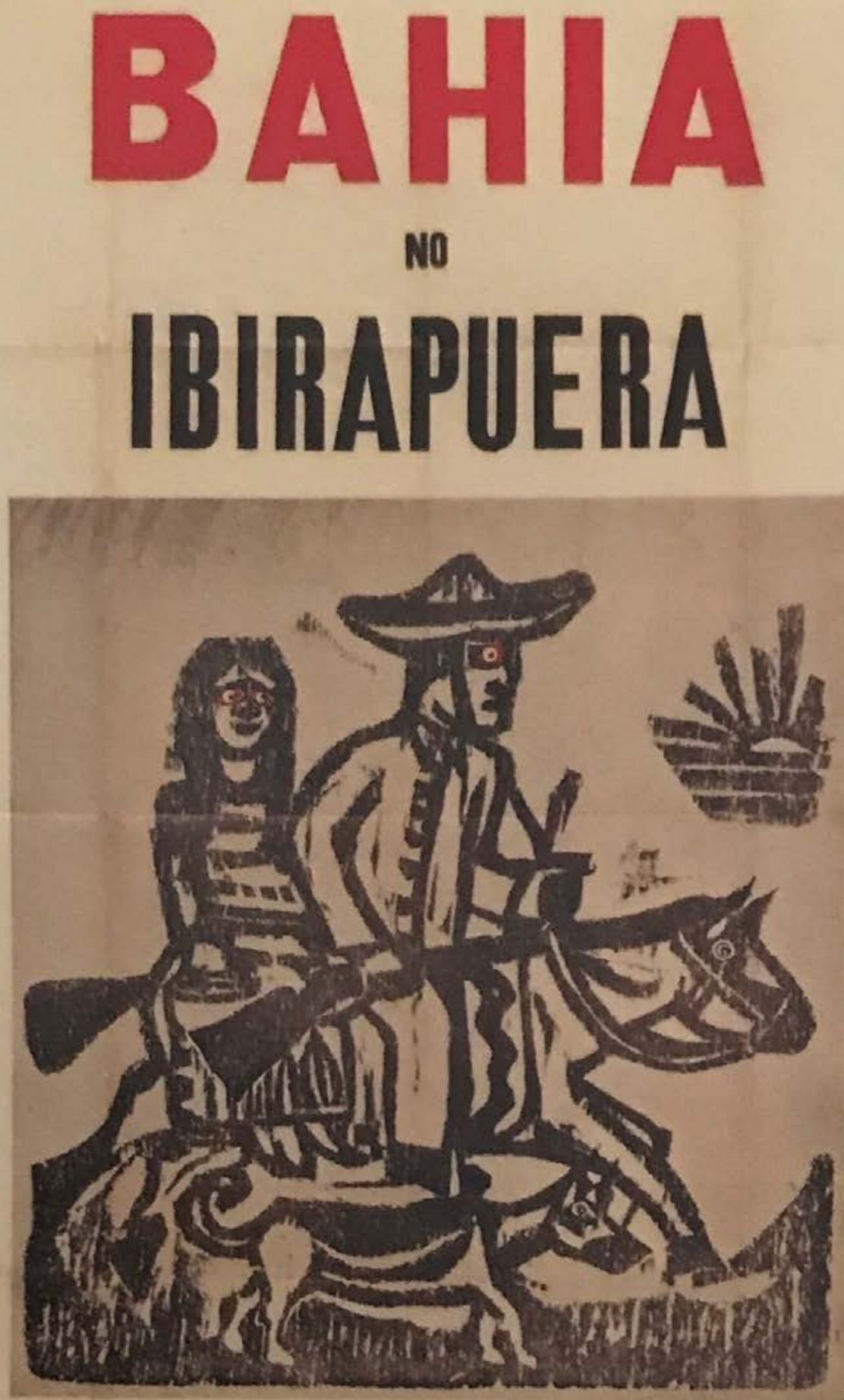

\section{VISIIE A EXPOSIC̄̄̃O}

21 DE SETEMBRO - 31 DE DEZEMBRO DE 1959 - SAOO PAULO - BRASIL 
IERA A EXPOSICÃO BAHIA APRESENTACÃO DE
JMA CULTURA E NÄO MOSTRA DE EXOTISMO

facultura, ceramica, ex-votos, reupas, objetos de uso co:idiano, bringue
vivo entre Norte e Sul

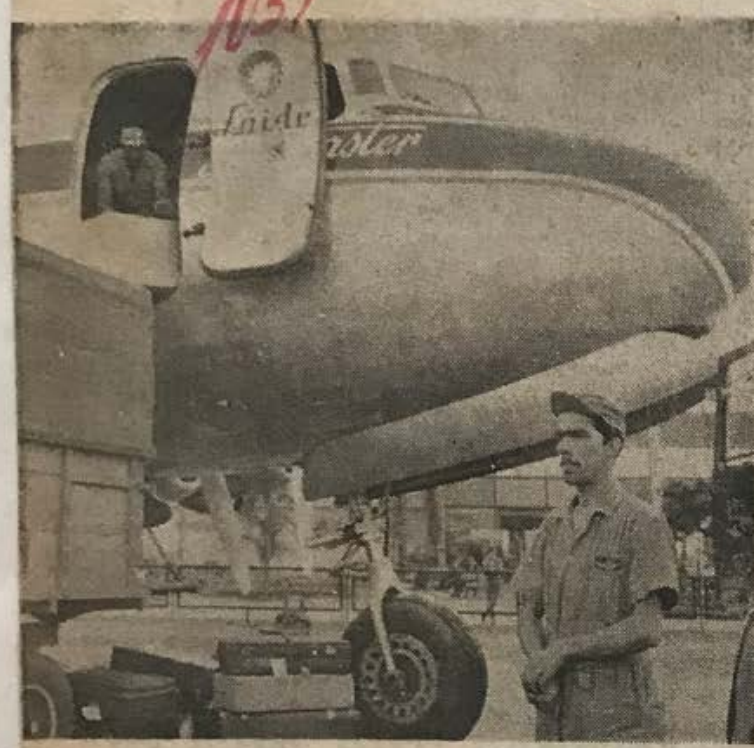

Caixōes e caixōes de peças foram desembarcatios em Congonhas, num trabatho conjunto do Loide Aereo e dos "Diarios Associados"
Sáo Paulo terá conhecimento da cultura popular do norte, a partir do dia 21 , durante a Bienal, da pela arquiteta Lina Bobardi, e pelo díretor da Escola de Teatro da Universidade da Bahia, sr. Martim Goncalves, e promovida pelo LoiGoncaives, e promovida pelo Loimo da Prefeitura de Salvador "Diarios Associados".

Nấo será uma mostra de carater típico, pitoresco ou regional, mas uma exposiçáo didática e vi. va de toda uma cultura popular de toda a atmosfera e realidade humanas de uma regiấo. No dia 21 , todo um pavilhấo do Ibirapuera mostrará ao povo grande va-

A exposiçăo, meticulosamente preparada por Lina Bobardi e Marparte parte movel e outra tixa, no inpovo, para além do simples contato com as peças expostas.

A parte fixa será representada A parte fixa será representada
por uma visão da Arquitetura coce do ce a roteiro de ce a um roto conhecimento pecas de pecas de ceramica popular, de de escultura negra, apetrechos miudos de cozinha e de uso cotidiano do povo, roupas, brinquedos, instrumentos de festas popudo povo ai figuraráo. Todavia, esses objetos nâo serâo mostrados como se faz habitualmente: serăo como que a história da cidade contada atraves de suas peça. A parte móvel será uma especie da cidade viva, ou seja, gen-
te e seus costumes mostrados diretamente ao público. Capoeiristas, tocadores de Berimbau e de Atabaques, e baianas vendedoras de guloseimas, o canciomblé, estarăo presentes, corrigindo os êrros da propaganda turistica. Essa apresentacāo do povo da Bahia em sua autentica maneira de ser será despojada de qualquer arranjo so-
fisticado, visa sobretudo a um con fisticado, visa sobretudo a um con-
tato humano. a um diálogo entr o povo de Sẫo Paulo e o povo da

Bahia.

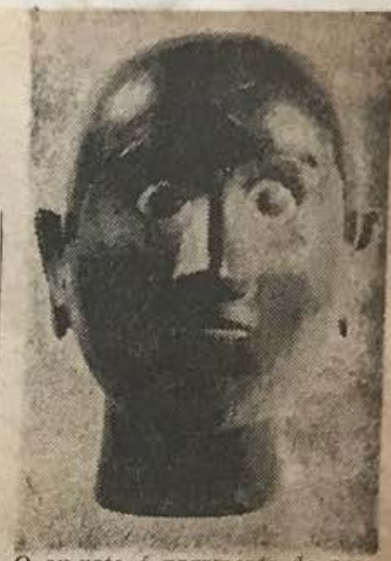

O ex-voto é pagamento de pramessa. O povo baiano faz na corpo curado a parte de sentos protetores. Coleciond e o servico de documentecio du e o serviso de documentacao di dade da Bahia recolhem e pre. servam esses documentos vivos de uma tradicão popular que marca a Bahia. Grancie amostra de ex-votos estará na Exposiç̃o Bahia, no proximo dia 24 em Ibirapuera

Contra o exotuco

A reaçâo que porventura possa ma de acusacōes posiçáo, em fore e regional deve ser logo preista e respondida em beneficio da harmonia da cultura do norte em face da cultura do sul. Lina Bobare apresenta Amado, que escreveu a curam trata de uma culturovar que se da exploracẩo pretenciosa e nẫ mas inéditos.

Nesse sentido a Exposiçَ็ $B$ hia poderia ser apresentada $\mathrm{cm}$ ualquer outra zona cultural do munda. A ceramica, a arquitetura arte popular em geral. fazem arte de um trabaiho exaustivo da scola de Treatro da Universidade Bahia, que visa justamente a ma integração e nao a uma aticional E', de desenvolvimento uma mostra suas raizes, africanas e povo, de sas misturadas, numa portuguetem multo de misterio e de poesio. antes de ser pitoresca ou exótice. 


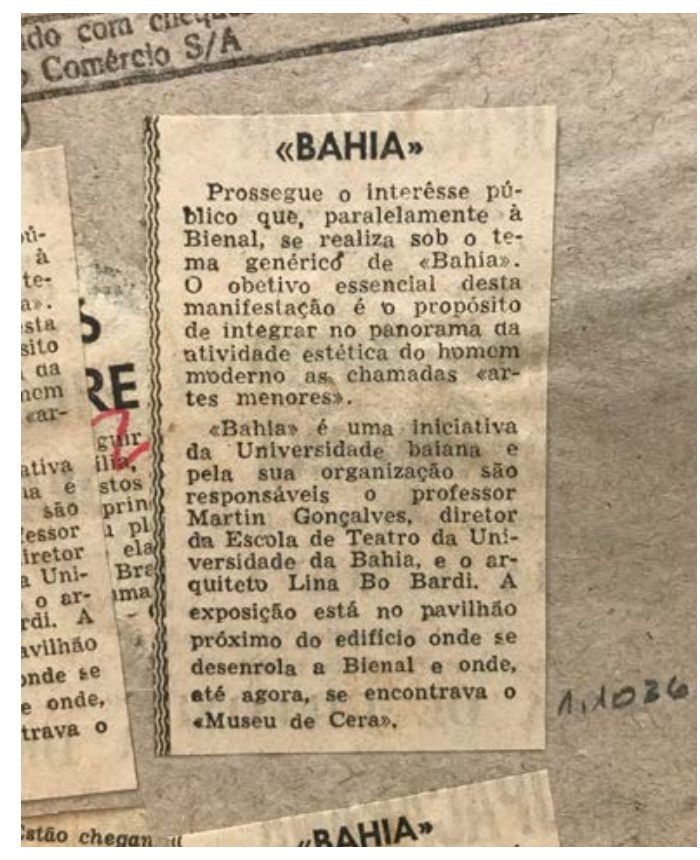

IMG 101.

Recorte de jornal Bahia no lbirapuera.
DIARIO DE SÃO PAULO

I8 - 9 - I959

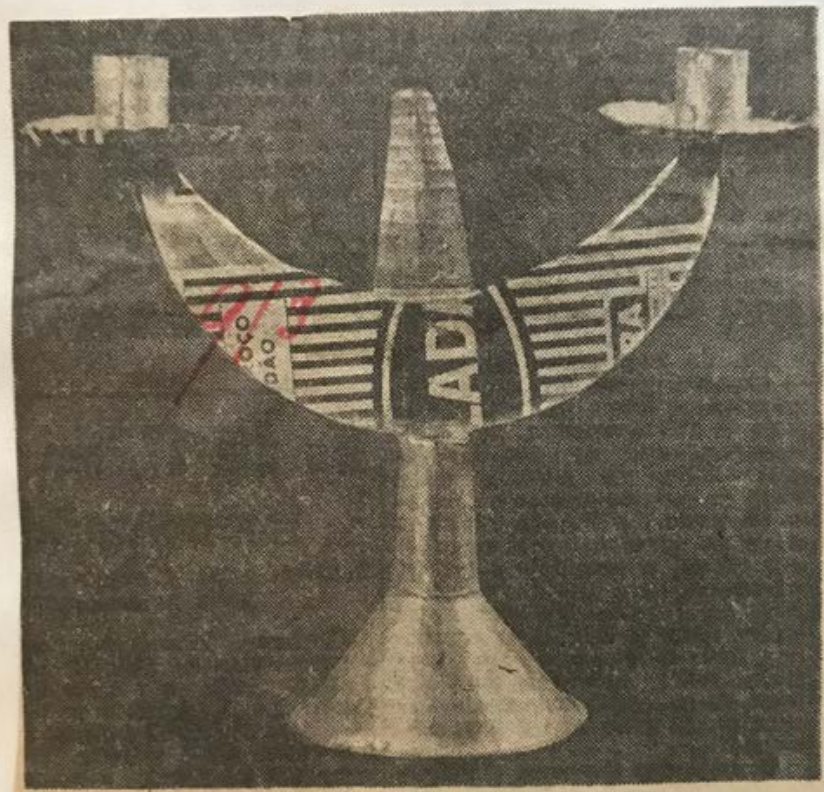

EXPOSICÃO BAHIA - Recortado em um pedaço de lata de azeite, este fifó é exemplo do artesanato popular de um povo, forma de arte valida, expressâo que é ao mesmo tempo utilidade, estará, ao lado de outros exemplos, na grande Exposiçāo Bahia, no próximo dia 24, no Ibirapuera. Essa mostra colocará ao lado da arte refinada dos grandes artistas de todo o mundo, a arte popular do Recôncavo, produto de uma cultura que se formou pela convergencia dos influxos portugués e afro-negro; ceramica, ex-votos, utensilios de cozinha, roupas, brinquedos - estaráo ai dispostos de maneira tal, que serâo como que o retrato material de toda uma concepção - do mundo, desenvolvida em terras tropicais -
$1 \cdot 10$

IMG 102.

Diario de São Paulo, 18 de set., 1959. 


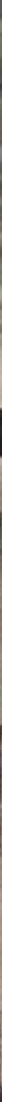




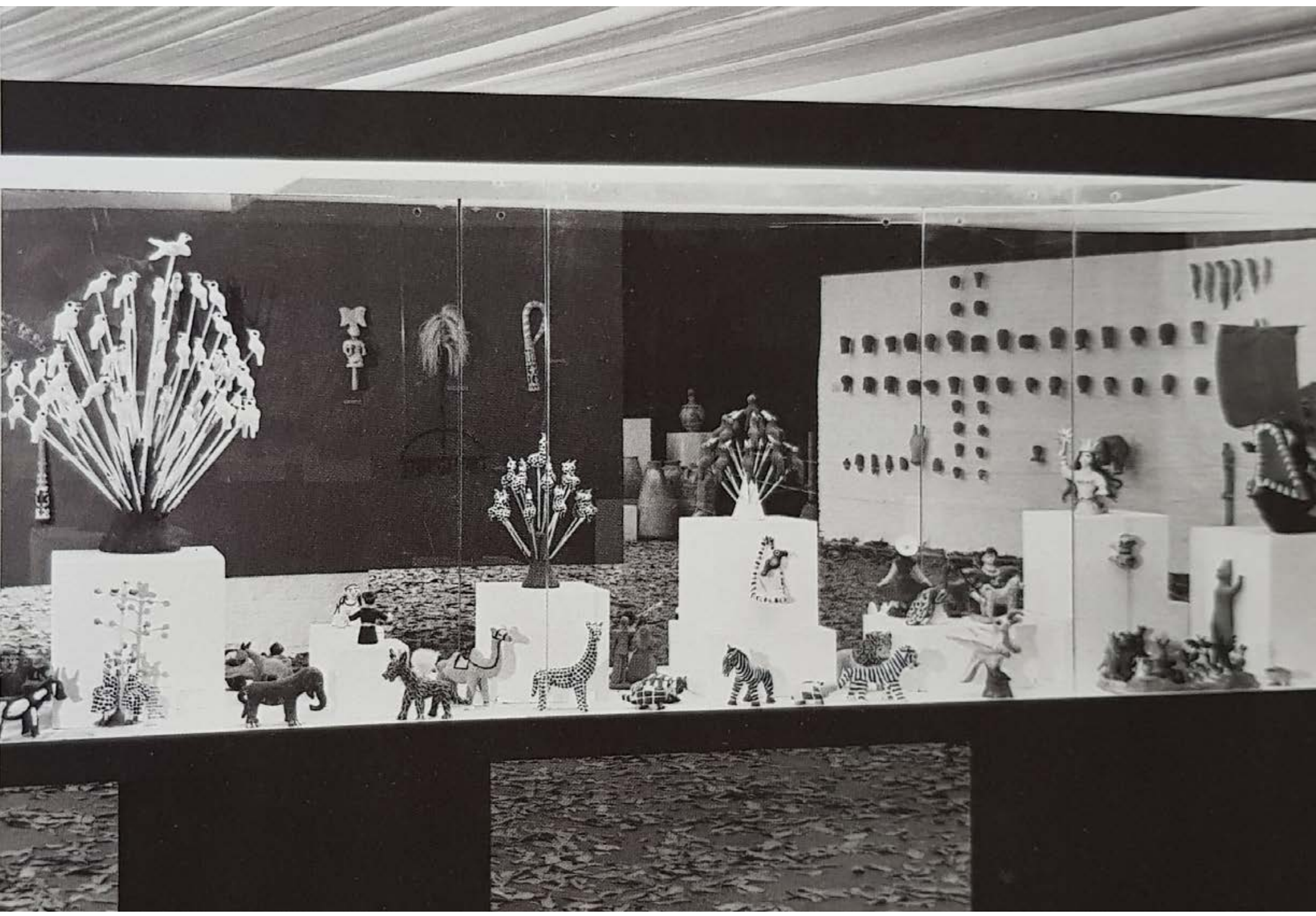




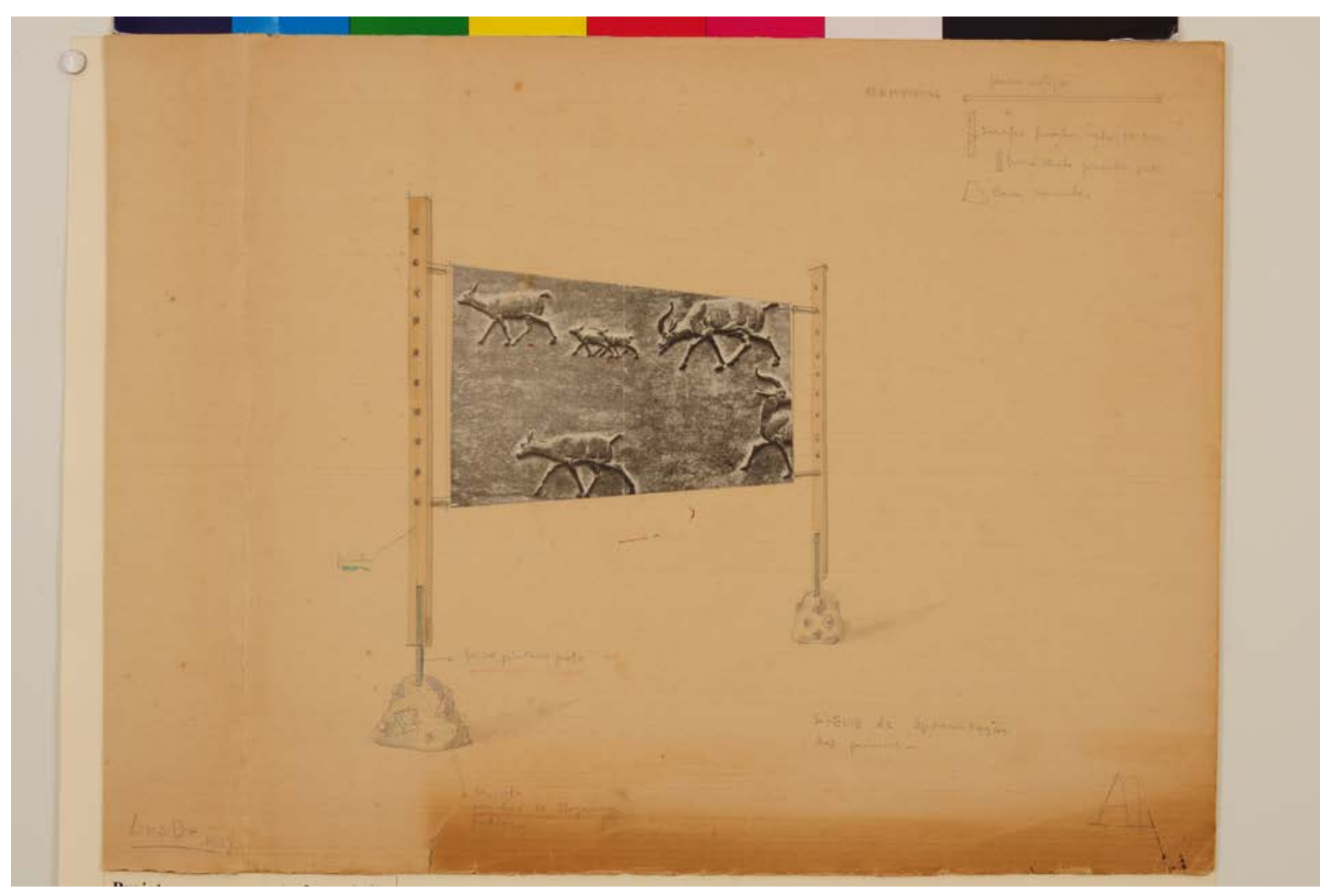

IMG 107.

Base concreto e

conchas. Arquivo 


\section{BAHIA}

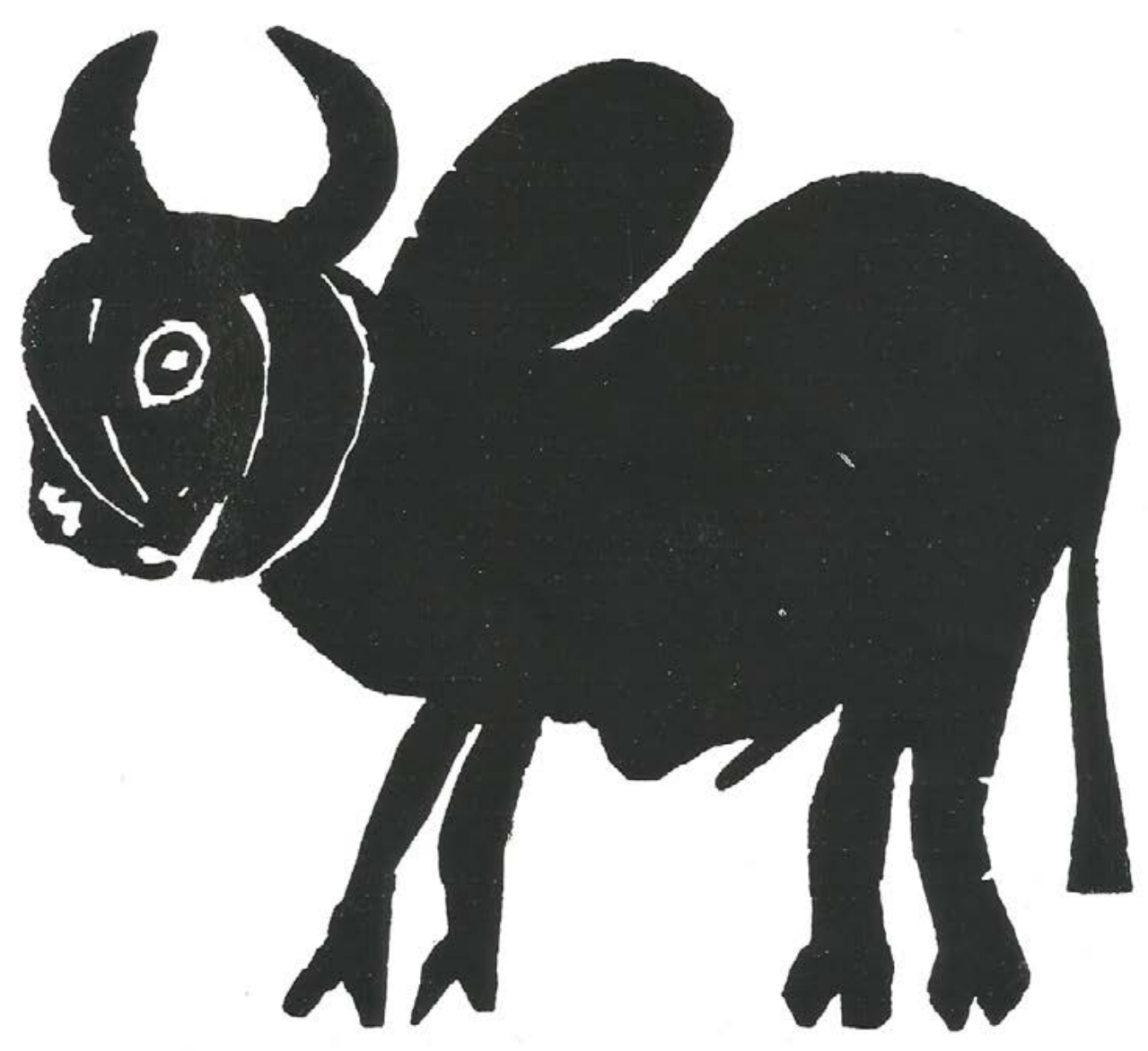

Exposição no Parque Ibirapuera São Paulo Brasil 1959 


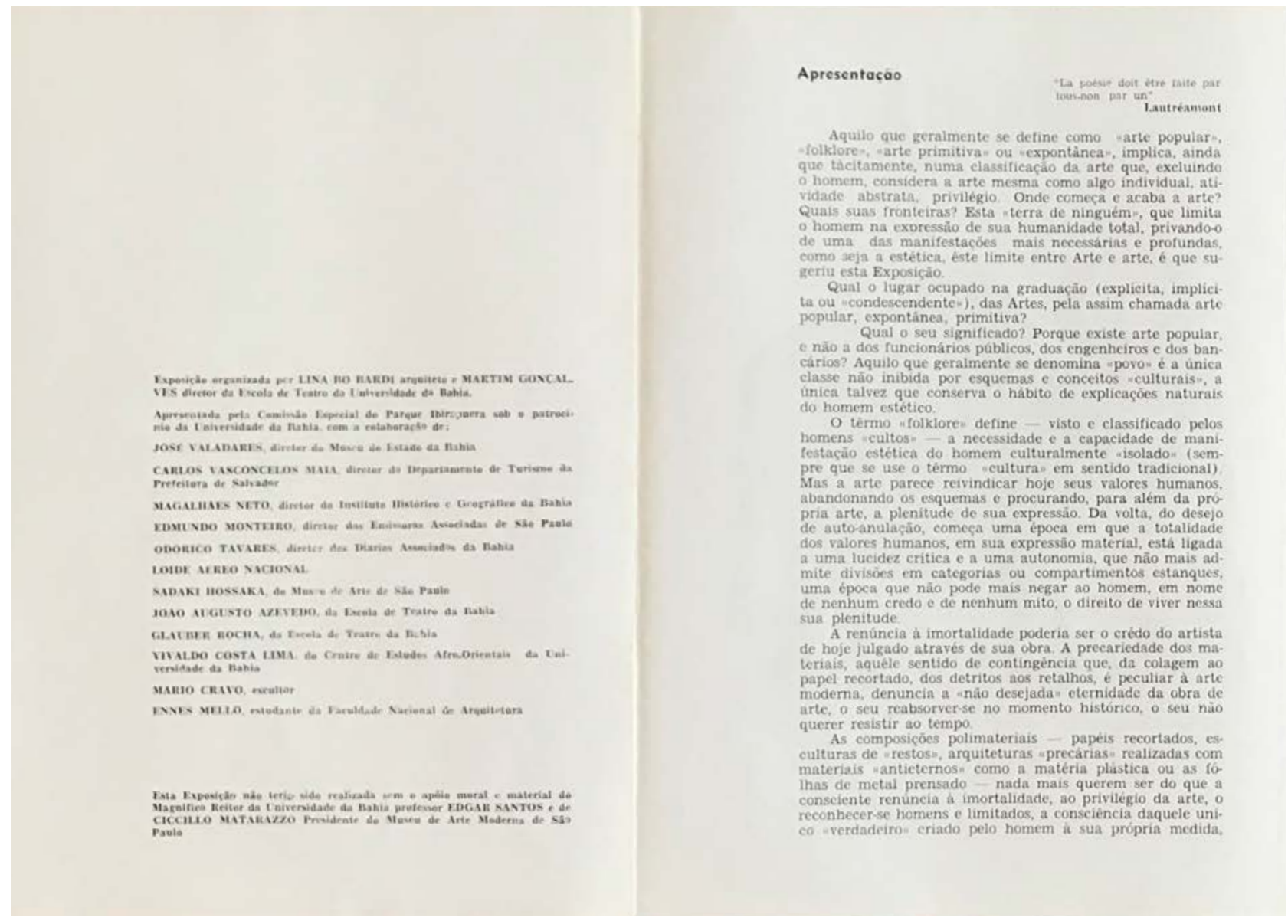




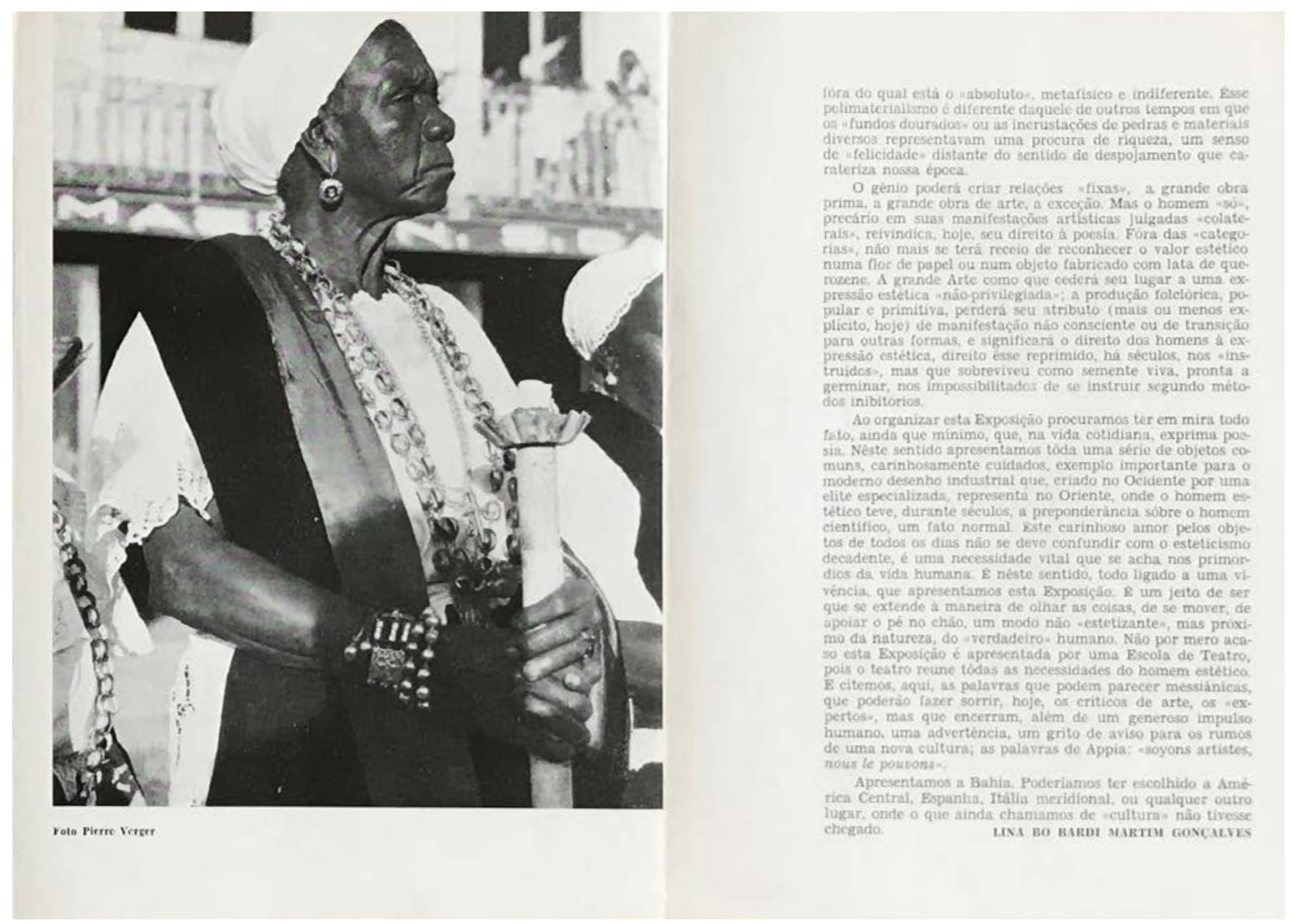




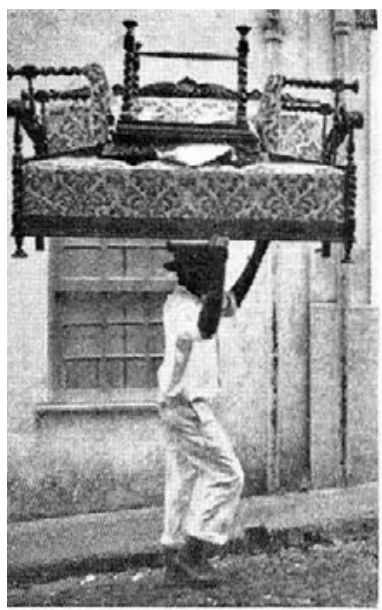

\section{B A H I A}

MUSEU DE ARTE MODERNA

por

\section{Lina Bo}

Apresentando o Museu de Arto Moderna da Bahia tentamos situá-lo em sua concretizaçâo histórica. Assumindo a direhistórica. Assumindo a 1960, ano de sua função em 1960, ano de sua fun-
dação, procuramos, por cinco anos uma 'necessidade' que tornasse justificavel sua atividade, numa terra cujas 'prioridades' poderiam năo ser as da Arte.

IMG 110.

Revista Mirante das Artes, Etc. 6 , nov. de 1967. 


\title{
Escola e "Movimento"
}

\author{
Este nosso não é um Museu, o termo é \\ impróprio: o Museu conserva e nossa pi- \\ nacoteca ainda não existe. Este nosso \\ deveria chamar-se Centro, Movimento, \\ Escola. ${ }^{61}$
}

Em 21 de setembro de 1960, na reportagem intitulada "MAMB Não é Museu: é Escola e 'Movimento'. Por Uma Arte Que Não Seja Desligada do Homem.", Glauber Rocha situaria o Museu de Arte Moderna da Bahia como "uma fonte permanente de polêmica", numa "Bahia popular, política e intelectual (...) dividida entre aqueles que apoiam e aqueles que criticam o MAMB", ,62 apontando o incômodo como resposta às ações institucionais apontadas por Lina em seu projeto pedagógico.

O MAMB como "escola" correspondeu não só à limitação dos seus fundos, mas sobretudo como uma estratégia didática que rompia com os conteúdos estritos das atividades diretamente ligadas, ou imaginadas, para um projeto de museu, aglutinando os movimentos de vanguarda que se estabeleciam em torno da Universidade. ${ }^{63}$

61 Lina Bo Bardi, "Museu de Arte Moderna da Bahia", em Lina Bo Bardi, op. cit., 139.

62 Rocha, Glauber. "MAMB não é museu: é escola e "movimento" por uma arte que não seja desligada do homem." Jornal da Bahia. Salvador, 21 de setembro, 1960.

63 Lina Bo Bardi, citado por Tales Ab'Sáber, em "Lina, Bahia, Glauber", Caramelo 4, op. cit.: 60. 


\section{MAMB Não é Museu: é Escola e "Movimento" Por Uma Arte Que Não Seja Desligada do Homem Reportagem de Glauber ROCHA}

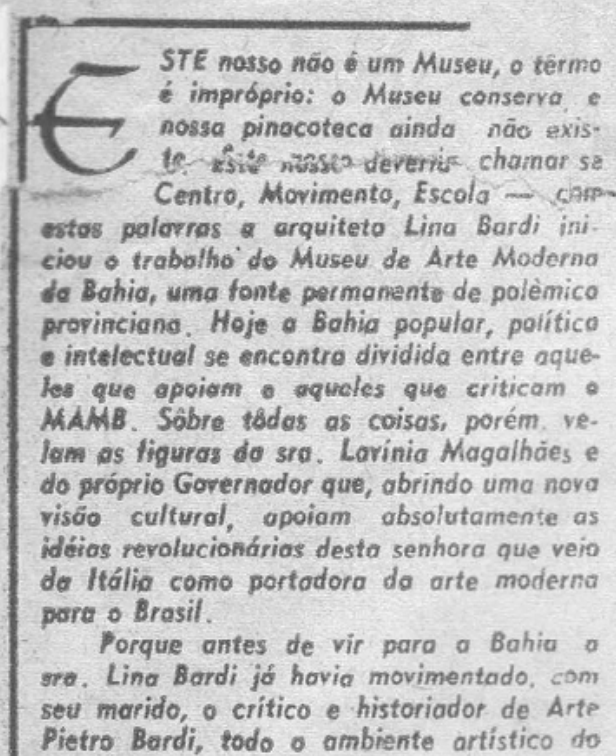

Brasil. Em Săo Paulo fundaram e imparsiona. rum o Museu de Arte, realizaram exposiçöes, conferencias, escolas de teatro, música, dança e iremo, convidando inclusive Albe to Cavalcanti para vir ao Brasil. Foi desto vi. sita de Caralcanti que nasceu a "Vera. Crux" foi da "Vera-Cruz" que tivemos tilmes de classe internacional, como "Cangaceina" e "Sinhá Moça". A arquiteto Lino Bardi convence pelo trabalho. Apesar te to. das as criticas que encontrou pela trente. da quase totol ausêncio de material hu. mano que prestosse a sua colaboraçáo reolizou em menos de um ano exposiçâs qu: deslumbraram a Brasil e que trouxeram a Bahia momentos fundamentais da arte on. tiga e moderna. Em menos de um ano o $M A M B$ introduziu uma nova otmosfero na Bahia. Sem dúvida, aquêles que ainda nĩo acreditam no $M \triangle M B$ estôo cada ver mais perdidos. A gvidência dos fatos consagra a capacidade de sua dinetora.

\section{Roteiro (intimo)}

Lo AMAMB

Varnos esclarecer o MAMB micialmente, a sra. Lina Bard cetesta a sigla e usa sempre "Museu de Arte Moderna". Rete KAAME, porém, funciona no esqueleto do incendiado tensamante. Poucrs pessoas trabalham 14. HA o jovern D. Carmem, eue assistem bem is noites, quando neces. tragsio geral. Yiraldo Costa Lima presta ums ajuda extrb. othial. Fora disto, ninguen tials ajude o dakns. Tocavis. vale mais que o produto de vma equipe masculina.

As exposiçoes sho continuas. $\$$ cada uma tras algo de novo para a Bahia. O sentido poie. mico, antilprovinciano e snti ccadernico es tensx o aigutis choxues foram dacos á Bahis quanda, por exemplo, o sak: is, prática japonesa, sol ieva ds publicamente pelos pinto. A ara. Bardi (D. Lina eutre Teatro Castro Aives e rivo in asario Sobral - a secretaria diretor durante o dia; e tam

nós todos) executa tudo wm maior rigor e criterio. Viva! du traduz trechos, reescreve outzos textos (D. Lina escreve seu estillo é de uma inciş́ fantástica) Sobral monts os "stands" Ests é s vida intima do Museu de Arte Moderms. D. Ing no gasta rios de di hetro como sasta rios de di nheiro, como muita gente pensa Teatro Castro Aives com nó Teatro Castro Aives com maximo de Imaginaça. Cat tinas de pano grosso e barrats. com a maior simpticidinde com a maior 0 simpitoriciade coliras de couro cri e é for. cadeiras de couro cri ara ḱ for. rado de estelras. A arquitetr. r 3 e a decoracho da sra. Bardi buscaram em elementos fun nossa cuitura popuiar sede. Per certo fol esta simplicidade esta coragem em despir a arte ae um sentido (snob" e ic. chado em torres de marfim que teriu a sensibilidade de certos intclectunis provinaianos $c$ an siosos por uma arte individua particular. Mas, além Las nsposicóes, o MAMR resiuz muito mais. Vejamos.

\section{O MAMB}

- Museu de Arte Moderna foi criado pela lei 1152 de 23 de Julho de 1959, redação de Walter da Silveira, juncionada pelo Governador Juracy Magalhães.

Presidente: Lovinia Magalhães.

Diretores: Assis Chateoubriand, Edgar Santos, Clemento Mariani, Gileno Amado, Fernando Corrêa Ribeiro, Miquei Colmon

Diretor Geral: Lina Bó Bardi Tesoureiro: Odorico, Tavares.

\section{Escolas}

Uma delas chamaro "Escota da Criança" " tem Martin Goncalves id frente, assistido peio pintor Sante Scaldaferr. que é a Escola da Crian, $\mathrm{ga}^{2}$ ? $\mathrm{Em}$ primeiro lugat, $\mathrm{n}$ (ă duma "oscolinha de arte" que planejs criar mentnos prodi. gios. D. Lina ná acredita en arte infantil. Acredita, wito sim, nas possibilidades de de envolvimento da personalida. de infantil. Martim Gonçalves, que é psiquiatra além de dirs. for teatral, orienta 0 curso para crianca e para professo. res. A Escola desenvolve is sentidos $e$ as possibilidades of açao, de atuto_conhecimento da crianca. Is uma escola nova sem esquemas dirigidos, onje a liberdade total da infancia para urna realizaçắo conscien. to ide seus atos) é o motres fundamental.

Criança do povo, criança ds classe média e criança da our. Juesia estudam nesta EScola. ausencia de preconceitos es co frualdade social, $\mathrm{z}$ parte ce lgualada social. sentidin de vida educada.

Ao lado da "Escola da Cra Anca" existe a "Escola de Mú sica Infanto.Juvenil", que d" sices Infanta-Juve astidóes musicais das criancas a dos fovens, 30 ib

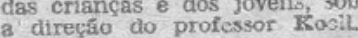
reuter.

Planos

Os planos da sra, Lina Bardi: - Uma Escola de Arte. sainto. de Desenho Irdustrial,
de Artes Industriais. Km suma uma Universicacie Popular. D. Lina acredita que o Brasil pos. sui um vasto- é médito materi al para uma cultura nova. Fs. tranhamente esta sus atitude irrits a outras mentalidades retrogracas que sonlism com a decadôncia ouropéia, quam do vivem no centro de unia arte e de uma vida latentes D. Lina acrodica dia que arte possa viver desassusociacia do hornern. A Universidado popu lar seris a valorizaciao dos nossas costumes objetivos (dav) nossas práticas, como a cera mica, artefatos, escultura e pin. tura primitiva) elevados a con diça de elementos uteis a uma anciedade em desenvolvimen to. Sem duvida, temos um: pretensấo tremendamente de vanguarda dentro de um ES. tado onde as valores intalec. tuais estăo, em sua maioria, tuais está, em sua maisma ver botragico e decadents.

Por estas icléias, o MAMB tem sido und foitte de pole mica. D. Lina, coirtridn. cun cis. Um dêstes "chocues" ê a presente exposiçâj jardim cie Roberto Burle Marx.

Compreende a existericia de urua Natureza fantástica om torno de nós \& compreendo: que utilizar este mundo em de lirio nums osian estetica social ê, sem dûvida aind muito dificil porn a rinhia Todavia, D. Lina tem planos para levar adiance este traba ho,

b) - Uma revista popular Popular desde o papel, desd a capa, descie a lingusgem

Uma revists nảo de este ticas interiores" mas uma re vista de critica social. Esta re vista será, sem dúvidis, o maio abalo sócio_cultural da Bahia Os costumes do povo, desde as gravatas ate o estilo hiterarias súo objetos de estudo. I isto que seria um verclacieiro Mfuseu é a propria vida moderna e 1 já os borróes nos quauros; os pot. mas pernósticos, a lirejarara reacionária.

D. Lina adora a palavra "rea cioń́xia". Nä́ a căa vagamei2 
Lina não estaria sozinha não estaria sozinha nesse movimento de superação do atraso frente às metrópoles do sul. Ao lado de Martim Gonçalves, além das referidas exposições Bahia (1959) e Ópera de Três Tostões (1960), produziria Calígula, também de Brecht, em 1961. Ambas as peças do dramaturgo alemão seriam apresentadas no Teatro Castro Alves, em cujo foyer se encontrava de forma provisória o Museu de Arte Moderna da Bahia. Risério apontaria que "o trabalho de Lina (...) entrelaça-se com a produção universitária, graças, principalmente, à atuação de Martim Gonçalves, à frente da Escola de Teatro" ${ }^{\circ 4}$

Corrobora a descrição de Jorge Amado para quem a vida popular de Salvador e a Escola de Teatro eram "uma e única coisa". ${ }^{65}$ Lina referia-se a Martim como "o brasileiro mais brasileiro", cuja obra possuía "um caráter social da maior importância" ${ }_{66}$ - (o que não pareceu suficiente para evitar a saída do diretor à frente da Escola, em 1961).67

O escultor Mário Cravo, a partir de sua atuação artística popular organizaria exposições e debates sobre arte moderna, além de abrir seu próprio ateliê como laboratório experimental para outros artistas. ${ }^{68}$ A ele, Lina projetaria uma casa, em 1958, na direção da matriz bruta das casas Chame-chame e Valéria Cirell. Mário Cravo faria parte, ainda, da comissão que elegeria Lina para direção do Museu de Arte Moderna da Bahia e, após o golpe de 1964, assumiria, de forma controversa, seu lugar.

Odorico Tavares seria outro membro fundador do Museu de Arte Moderna da Bahia, integrante desta mesma comissão e diretor da subsidiária dos Diários Associados na Bahia ${ }^{69}$ Cronista, poeta e colecionador, caberia a ele os esforços de documentação e divulgação da produção dos artesãos e dos artistas baianos, a quem ofereceria oportunidades na divulgação do trabalho, tanto no Diário de Notícias quanto na TV Itapoan, responsável pelos primeiros sinais de televisão locais. Ligado ao MASP, escreveria sobre a Bahia, na Habitat. ${ }^{70}$

Integraria também à comissão do museu baiano, José Antônio Prado Valladares, diretor do Museu Estadual da Bahia, o antropólogo Vivaldo da Costa Lima, e o escritor Jorge Amado, para quem "o povo [era] mais forte do que a miséria". ${ }^{71}$

64 Antonio Risério, op. cit. 79

65 Jorge Amado, texto incluído no catálogo Bahia, Exposição no Parque lbirapuera, São Paulo, 1959.

66 Lina Bo Bardi em Arte na Bahia. Teatro na Universidade, op. cit., 12.

67 Com apoio da Fundação Rockefeller, a ETUB traria inúmeros professores estrangeiros, ligados inclusive à formação do método Stanislavski ensinado por Martim Gonçalves, ex-aluno do Actor's Studio, em Nova York. Entretanto para a esquerda estudantil, a escola seria "um centro de diletantismo internacional pago pelo contribuinte soteropolitano". Ver Paulo Francis, coluna de teatro, Tarde (12 de dezembro de 1960.

68 Antonio Risério, Avant-garde na Bahia , op . cit. 24.

69 Para Lina, Odorico entregaria a página de arte do Diário de Notícias.Ver Maria Cecília França Lourenço, "Lina Bo, um meteoro no M.A.M. - Bahia", em Museus acolhem moderno. São Paulo: E.D.U.S.P., 1999, p.178.

70 Cf. Odorico Tavares, "Imagens da Bahia", Habitat 9 (out.-dez. de 1952): 42-43. Além disso, participaria do documentário Magia Verde, de Gian Gaspare Napolitano. In: "Magia Verde", Habitat 10 (jan-mar de 1953): 84

71 Jorge Amado. Bahia de Todos os Santos: guia das ruas e dois mistérios da cidade de Salvador. São Paulo: Companhia das Letras. 2012, p.22.

IMG 111.

Jornal da Bahia. Salvador, 21 de set., 1960. 


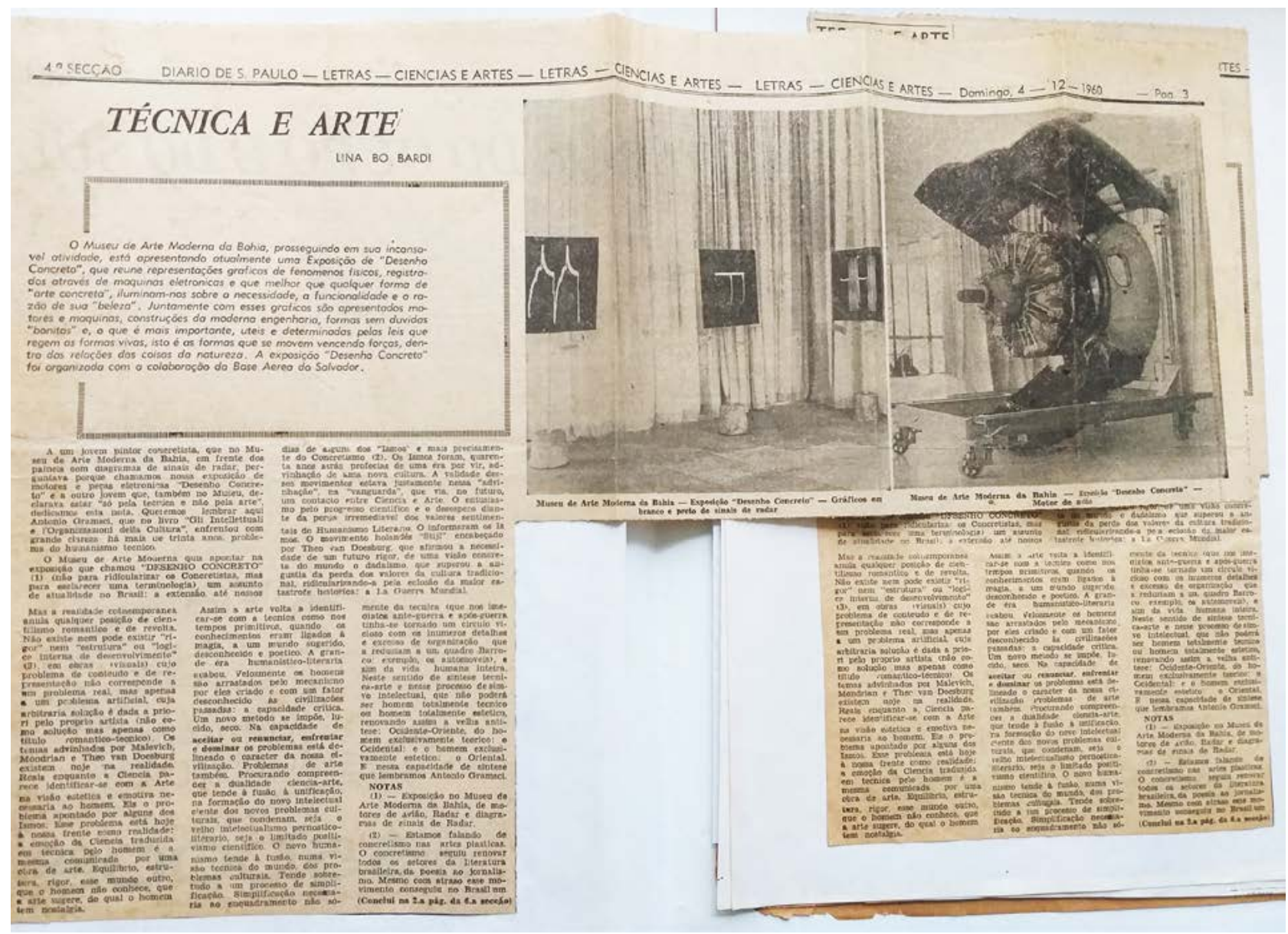

\section{TECNICA E ARTE}

(Conclui na 2.a pág. da 6.a seccáo) resultados real. que nầ foi conseguido em quarenta anos em paises mais quas de anos mentos culturais. crso da culturais. busier na moderna de Le Corbrasileira moderna arquitetura brasileira. A diferença entre poesia e artes plasticas, com respeito to concretismo, é a diferença de meios de expressāo e (mais) de conteúdo. Enquanto a poesia concreta corta a linguagem para chegar mais depressa, para comunicar mais rapidamente \& ideia, nas artes plasticas o concretismo contemporanco é coisa puramente formal, que se limita iे forma. elirenca "tecnica" é un du exemplo da năo completa "identidade das artes" (conforme a definiça Crociana) e da sua náo ab. soluta independencia no que se refere aos meios tecnicos de expressão.

(3) - Catalogo da Exposiçào de Arte Concreta, no Museu de Arte Moderna do Rio de Janei10. Citação de Max Bill.
Entre o espírito libertário e o espírito liberal vive a Bahia. Nunca fascista, se bem por vezes reacionária, saudosista, enamorada de fórmulas passadas. Mas por outro lado, revolucionária, afirmativa, progressista e, se absolutamente necessário, violenta. Essas duas figuras do seu passado e tudo que elas representaram dominam a mentalidade da Bahia (...) O conservador e o revolucionário coexistem no espírito da cidade, chocam-se, fundem-se por vezes, são quase palpáveis no seu contraste. Aqui o viajante verá diferenças mais absurdas em todas as coisas. Encontrará uma arte essencialmente política. ${ }^{72}$

72 Jorge Amado. Bahia de Todos os Santos: guia das ruas e dois mistérios da cidade de Salvador, op. cit. pp. 21-22.

IMG 112. 


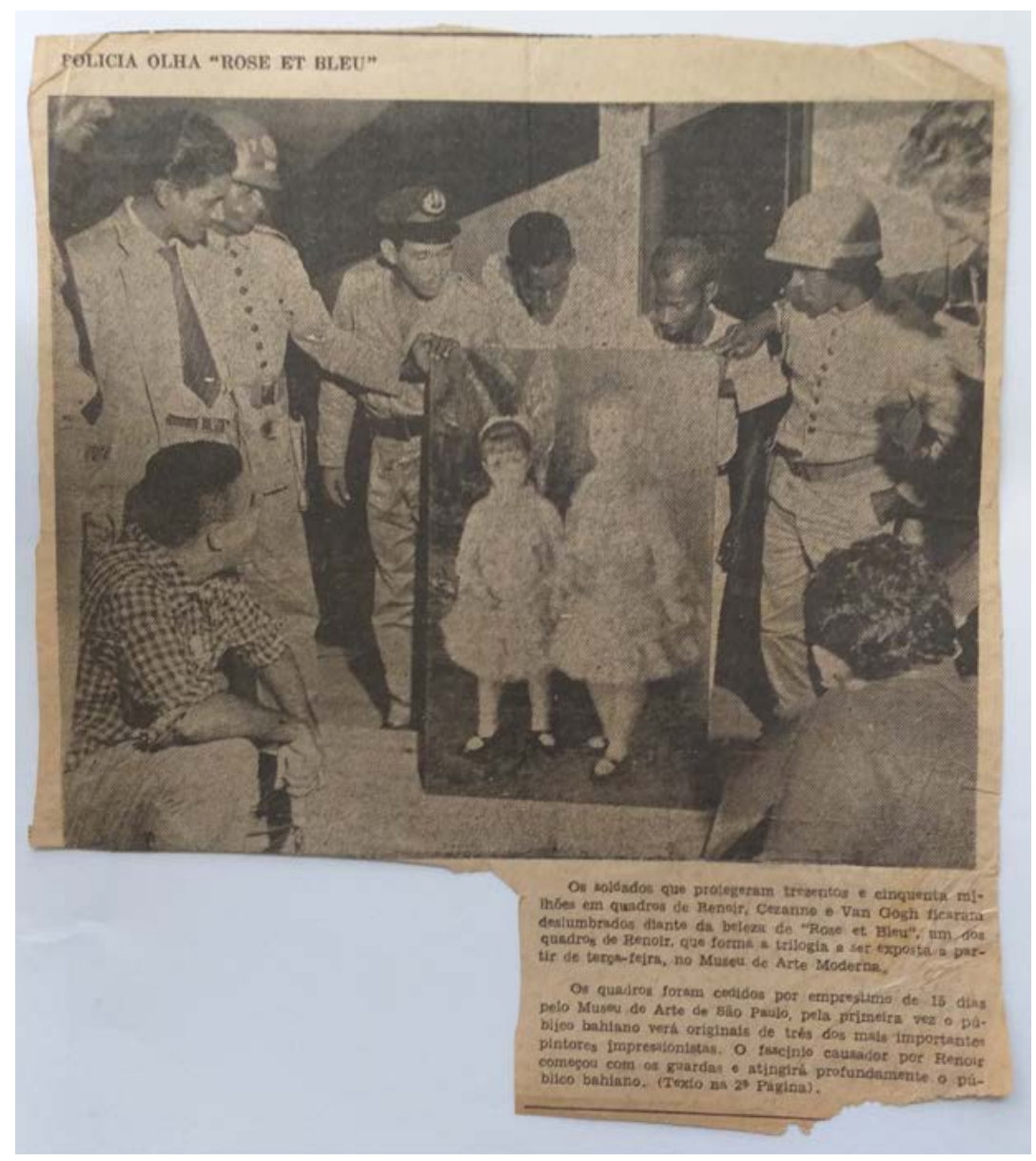

IMG 113.

Rose et Bleu.

Diário de Noticias.

Para Lina, "O Museu de Arte Moderna da Bahia, o último a nascer em museus brasileiros, [teria] o grande privilégio de poder endossar as experiências anteriores", ${ }^{73}$ legitimando sua experiência à frente do MASP, em São Paulo, cuja agenda didática redimensionaria, em solo brasileiro, a experiência do MoMA. ${ }^{74}$

É certo que existem [no Brasil] muitos museus: nenhum, porém, se dedica ao estudo e à difusão do conhecimento da arte moderna. Também é certo que, nas grandes cidades do mundo, funcionam museus deste tipo. Mas, quando a Bahia se distingue, nacionalmente, e até internacionalmente, por seus artistas modernos, quando acolhe e inspira grandes artesãos contemporâneos de outras terras, quando se inquieta por conhecer o trabalho e a crítica que se faz em torno dos maiores criadores de nosso tempo, não se indaga se ela imita uma atitude estranha aos seus conceitos e à vivência, admite-se que the seja próprio agir e refletir desse modo. $E$, de fato, a Bahia deve ser uma cidade aberta às expressões contemporâneas da arte. A tradição de seus aspectos reclama esse favorecimento. ${ }^{75}$

73 Lina Bo Bardi, nota sobre MAMB, sem data, arquivo MAMB.

74 Leo Gilson Ribeiro, "Entrevista com Lina Bo Bardi", suplemento de domingo do Jornal do Brasil.

75 "A formação do Museu", artigo não assinado, datilografado. Arquivo Museu de Arte Moderna

da Bahia, Salvador, Bahia, parcialmente reproduzido em Silvana Barbosa Rubino "Gramsci

no Museu, ou a arte popular no Solar do Unhão. Salvador 1963-64", p.4. 
O estatuto moderno do museu estaria exatamente nesta chave que combina consciência crítica e continuidade histórica, nas relações do homem com a natureza, a partir da produção de sua vida material, trabalho este cuja "orientação da arte moderna em relação ao fragmentário, ao modesto, ao passageiro e ao não-eterno [estaria] intimamente ligada ao processo de humanização da arte ". ${ }^{70}$

A elite intelectual soteropolitana entendia o patrimônio cultural de Salvador como um recurso para o progresso imaginado para a região. Muitas vezes, a postura combativa e moderna de Lina chocou-se às ideias enraizadas de uma elite intelectual patrimonialista. As ações de Lina responderiam, ainda, à discordância em relação ao paternalismo que governava a transferência cultural entre a intelectualidade e o povo, já tensionada na mediação com a própria militância soropolitana. "As classes populares (...) também são possuidoras de uma cultura que deve ser explorada pelos intelectuais em termos de troca mútua, sem a presunção típica da cultura de intelectuais subdesenvolvidos e desenvolvidos". ${ }^{n}$

Lina inicia suas atividades, "eliminando a 'cultura estabelecida' da cidade e buscando o apoio da Universidade e dos estudantes, abrindo o Museu gratuitamente às pessoas, tentando desenvolver ao máximo uma atividade didática". ${ }^{78}$

O museu "procurará se afastar o mais possível do cosmopolitismo incolor e esnobe da pseudo-cultura moderna para começar a agir construtivamente no novo mundo da verdadeira cultura moderna. Nesse sentido, o Museu de Arte Moderna da Bahia, (...) aspirará entrar, sem retórica, na vida do País, buscando, acima de tudo, ser uma necessidade". ${ }^{79}$

76 Lina Bo Bardi, "'Artes Menores'. Notas Para Criação Duma Cadeira de Desenho Industrial", Ângulos, op. cit.

77 Entrevista de Lina Bo Bardi na III Semana Nacional de Estudantes de Filosofia, na Faculdade de Filosofia, Ciências e Letras da Universidade do Paraná, 1960 [data aproximada]. Arquivo M.A.M.B.

78 Id. "Cinco anos entre os brancos", Mirante das Artes, Etc. 6, op. cit

79 Id. Nota manuscrita, s/d, arquivo do M.A.M.B. Lina Bo Bardi, "Museu de Arte Moderna da Bahia", incluída na brochura de inauguração do Museu, e reproduzida em Lina Bo Bardi , op. cit. 139.

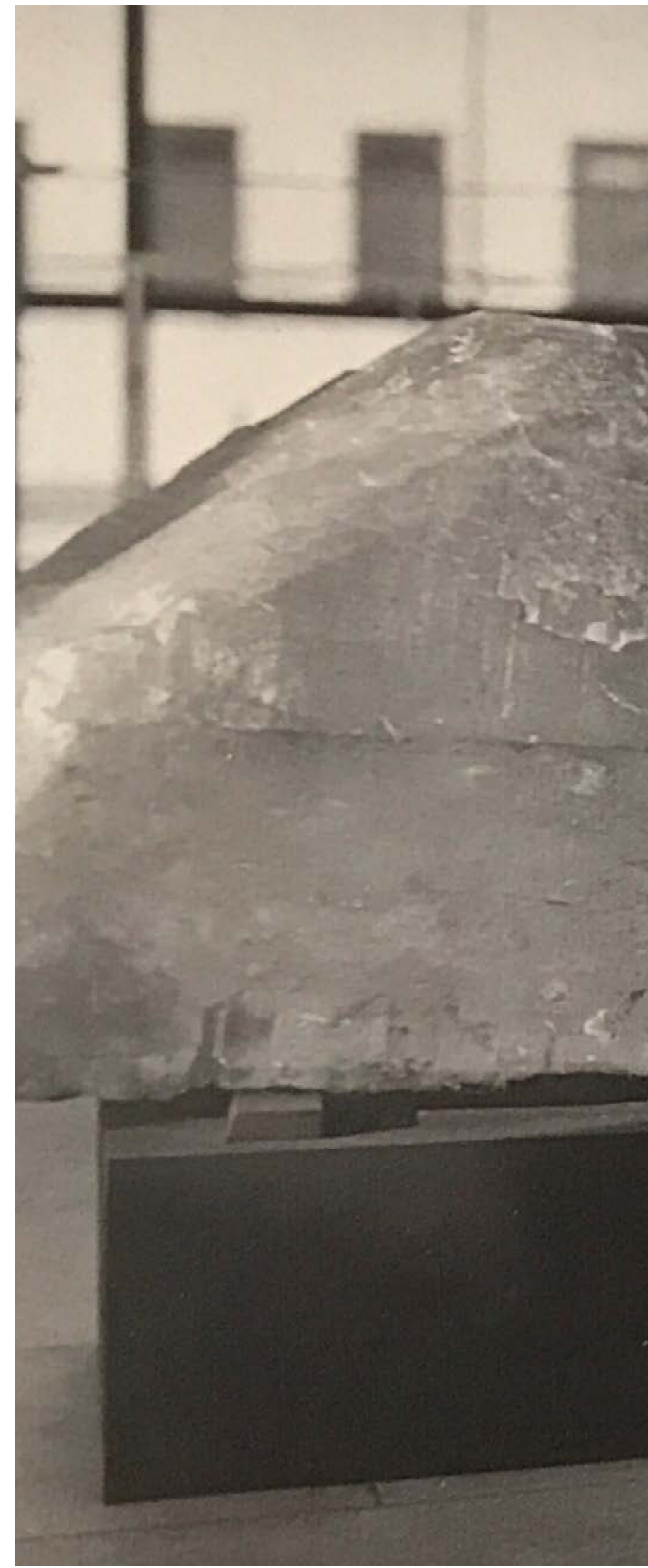




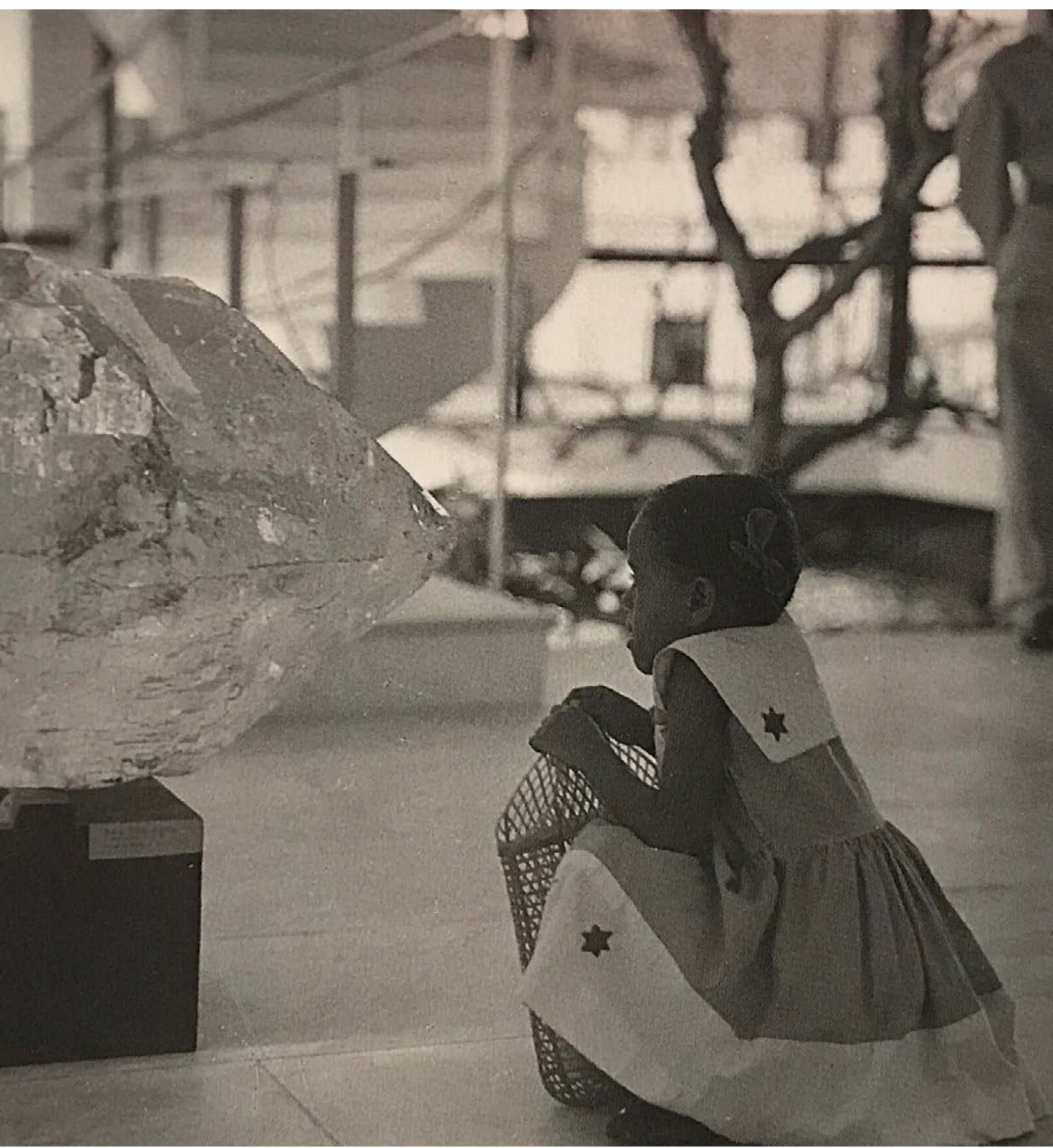




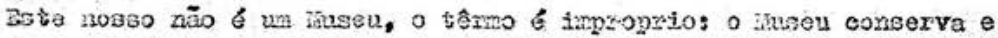
noess pineoctoca dinda não exinto. Sate nooso deverie chanar se Centro, Lovinento, Bscola, e a futura odleçãs, ben progranada sesundo aritérioa

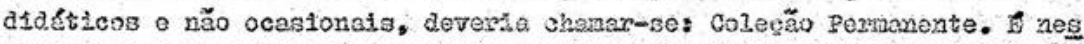
te eentido que alotanos a palavra surseu. L precteo trabsn ohegar-so a un

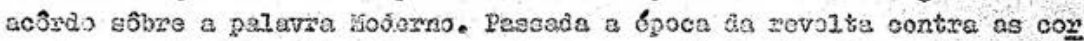
senter renotonéniss da crte, cescede a nocessidadar do "choque", do esvêdalo, chegados ao ponso en çw a aste moderna 6 aceits pos todos, \& necooolitio começar-ae a coastrujs considerendo encerreds o periodo da ne

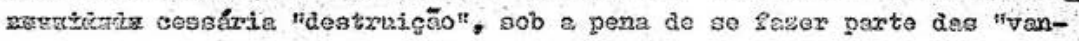

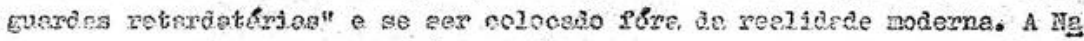
tureza o o minco das cotass \& a materia que oncontromos. De sues leis

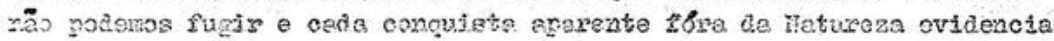

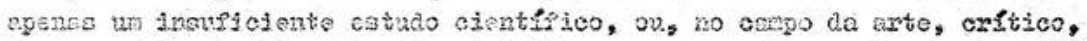
do desenvolver-se do fato. Por isto'e que exporros alpunas rorma naturois para pixar ber os lirities da arte zodema, que, as vires perece invadis - carmo do laturosa, da "materta prime" aature?.

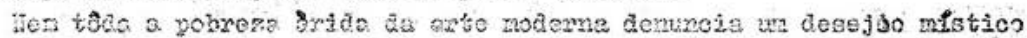

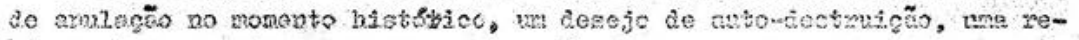
atrcta

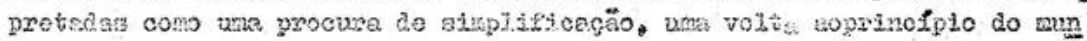

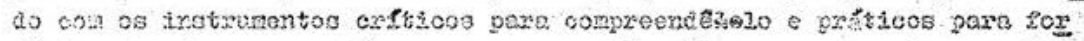

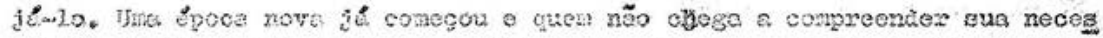

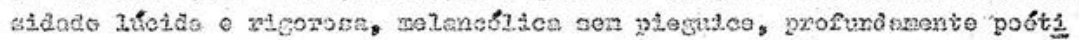

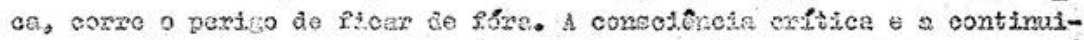
dade higtritico sã a grande leranģa do homen nodemo. Por tsio exponos e continuerenos a expor obras de pasrado. Procuromos isols-1 $I_{2}$, colock-1as em evidência cono "ncontecinento". e a comentanos con música da bpoca. De loto, se no conetdexer ura obre do pessedo, constderumos o moz to", o momento no qual foi executrala, nos a podezonos rovivex hoje ex súa

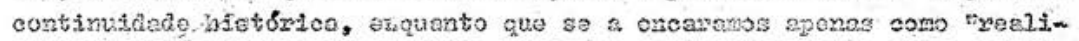
dade" de hoje, elininays a continutade nistbrica o pezdenos o passado de que o mocemo \& o resultado. He expostção termortíte, eliminamos a apresentogão critica, não por deserer da critioa, an porque estaroo conza

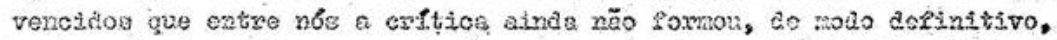

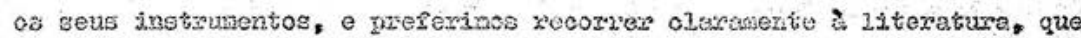
representao mudo brosizejro, etrala hojo meiss poético do que crítico, em vez de interpretagões hifrides, critico-literfítss, sen bases abrias. Acreditamos necessúrio regtabelecer a psesença do homer ne obra de axte.

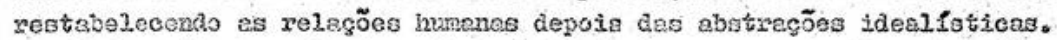

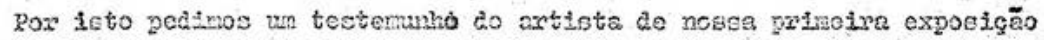
texportrita e apresentenos un pninel documentisnio de sue vica. Coreganos sen gxandes pegas ou grandes nowes. As bbres que apresentinos säo ndoa-

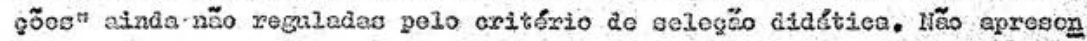

IMG 115.

Museu de Arte Moderna da Bahia. Salvador, [1959?]. Arquivo MAMB. tamos tôas as obras que possulmos, porque as obras de arte devem ser expostar, diremos, "Iidas", cono os livsos que se romen cos poucos, na hibllotosa. 0 nosso critbrio serk o do rotação das obras expostas. Apre sentanos une serie de esculfuras, parte de uma coleçäo emprestala por ou tro Husur. Apresentaremos o meis possifel obres empxestades de inuseus ou de coleçōes particulases, assim como organizaremos wa parte dedicada à

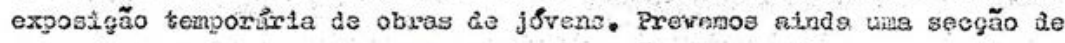
"emprestino" de obras de arte des exposiföus tempoxarias, a perticulares intercssadoe na sus aqquistç̣̆o, ní poxa estimular o mereado de arte, mas para cisar 0 intoresse pela obra de arte, o nábito. $80 x$ estas razões con stiasanos improprio o significado corrante da yolavxa fuseu e the atribuja mos wi outro santido. Aa sscolsa que en breve so jinstalarẽo no kuseu de

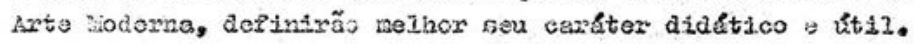


Lina defenderia a instituição como local da "SÍNTESE DAS ARTES, ou seja, uma colaboração estreita e vasta entre todas as formas de atividade artística" cujo "impulso e autonomia moral [...] são o prelúdio para a construção de uma verdadeira cultura", e pediria o fim da "Tribuna pública da imprensa para interesses pessoais [...] Somente [...] com base na autonomia moral, o Brasil poderá participar do convênio da Civilização e Cultura Mundial". ${ }^{80}$

O MAMB teria autonomia financeira e administrativa no desempenho de suas funções, a partir de sua constituição enquanto Fundação do Estado, ${ }^{\text {g1 }}$ o que possibilitou ampla liberdade à Lina na formulação de seu programa. Nas palavras de Lina, "o fato de ser uma Fundação Estatal lhe proporcionava a "validade' que só atividades públicas permitem, diferentes (mesmo quando 'público' não significa 'coletivo') da iniciativa privada, cujos interesses (disfarçados) são sempre lucrativos ou publicitários $"{ }^{.82}$

Assim, "O Museu de Arte Moderna da Bahia (...) não era um 'museu' no sentido tradicional: (...) suas atividades foram direcionadas à criação de um movimento cultural que, assumindo os valores de uma cultura historicamente (no sentido áulico) pobre, poderia, lucidamente, superar as fases 'culturalista' e 'historicista' do Ocidente e, contando com uma experiência popular (rigorosamente diferente do folclore), entrando no mundo da verdadeira cultura moderna, com o instrumentos de técnica, como método, e a força de um novo humanismo." ${ }^{23}$

80 Rascunho Texto de assinatura de convênio, s/d, escrito por volta de 1960. Arquivo M.A.M.B.

81 Em acordo com a Lei 1.152, de 23 de julho de 1959.

82 Lina Bo Bardi, "Cinco anos entre os 'brancos'", Mirante das Artes, Etc. 6, op. cit.

83 lbidem. 
Provisoriamente no foyer do Teatro castro Alves - TCA, após o incêndio que sofrera cinco dias após sua inauguração, em julho de 1958, arruinando o interior do teatro, sob os escombros, em 06 de janeiro de 1960 , o MAMB abriria suas portas. $O$ volume envidraçado do foyer funcionaria como uma espécie de vitrine e, assim como na exposição Bahia no Ibirapuera realizada no ano anterior, Lina faria uso das cortinas como recurso para recriar os ambientes conforme os projetos apresentados e sua relação com a Escola de Teatro da Universidade, com quem dividiria não só o espaço físico, mas uma agenda pedagógica.

Marcando à pluralidade do conceito de arte que regularia o programa de ensino do Museu, suas atividades foram iniciadas com uma conferência sobre cenografia, por Félix Labisse, advertindo que "ARTE é a totalidade das expressões estéticas do homem; é pintura, escultura, arquitetura, desenho industrial, artes gráficas, fotografia, artes visuais; Cinema, televisão, teatro. $O$ teatro é a mais completa das manifestações estéticas, reúne todas as artes em uma síntese vívida e completa". ${ }^{\text {.4 }}$

O teatro não só inaugura o programa de ensino da instituição como se desdobra em exposições paralelas, que muitas vezes estariam em correspondência às obras teatrais do TCA. Junto à Ópera dos Três Tostões, por exemplo, seria apresentado "o ambiente político cultural do jovem Brecht", ${ }^{35}$ enquanto nos escombros do teatro, se desdobraria a cenografia da obra teatral, bem como ocorreria em Calígula, obra também brechtiniana, encenada no ano seguinte. ${ }^{86}$

84 Texto datilografado sem título, escrito em Salvado, datado em 17 de outubro de 1959, mantido no arquivo MAMB.

85 Lina Bo Bardi, "Na selva das Cidades". reproduzido em Lina Bo Bardi, op. cit. 187.

86 Além das duas obras de Brecht, em outubro de 1961, seria encenada a obra de Thornton Wilder - Por um triz - dirigida por Charles Mc. Gaw. 
Um dos mais importantes acontecimentos oulturais dos íltimos tempos foi realizado na Bahias a assinatura do convênio Estadio, Universidade, MAMB. A assinatura dêste convênio não visa apenas a reconstrų̧̛̣ to T.C.A., como noticiaram os jornais, mas, principalmente, a estruturação de um novimento cultuzal que saia diretamente das raizes culturais brasileiras. Na qurilidade de Diretor do Mhseu de Arte Moderna de Bahia $\&$ o uinico Iugar do Brssil onde o roovimento artístico não está em mãos de aniaciores, ainds que bem intencionadois, culturalmente ineficientes, senão malêficos. E também o único lugar onde se eatá a realizar aquilo que na linguagem crí tica moderna se chama "SITTESE DAS ARTES", quer dizer uma estreita o vasta colabo raçã entre todas as formas de atividada axtística. Como téonico e professor universitário, quero afirmar ter encontrado aqui entre os estudantes aquêle impulso - autonomia moral que são o prelúdio da construção de uma verdadeira cultura. Fntretanto, para trabalkar a trabalhar em equipe, com a verdadeira colaboração de todos, nucessários se faz que estejam bam claros e discriminados os valores. \& pre ciso que todos especialmente os jóvens tomem consciência da verdadeira realidade cuitural o defendam o trabalho dediowio especialmente à novas gerações que corstruirãa, num futuro bem próximo, a Lultura liccionel.

Faz-se neoessário acabar con o personalieno políbico que, operando na base da chan tagem oultural fala a linguagem dos maís biixos e mesquinhos interesses, sob a mág

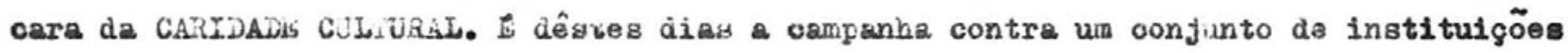
de elara s séria jiportância cultuzal e eaucativa. E neossaírio acabar oom o uso da Tribuia Pública da imprensa para interesses pessoais. Sòmente assim, somente trabalhandc numa atmosfera de verdadeira estima reof́proca, numa base de autonomia moral, é que o Brasil poderá participar do convênio da Civilização e da Cultura lundial. 


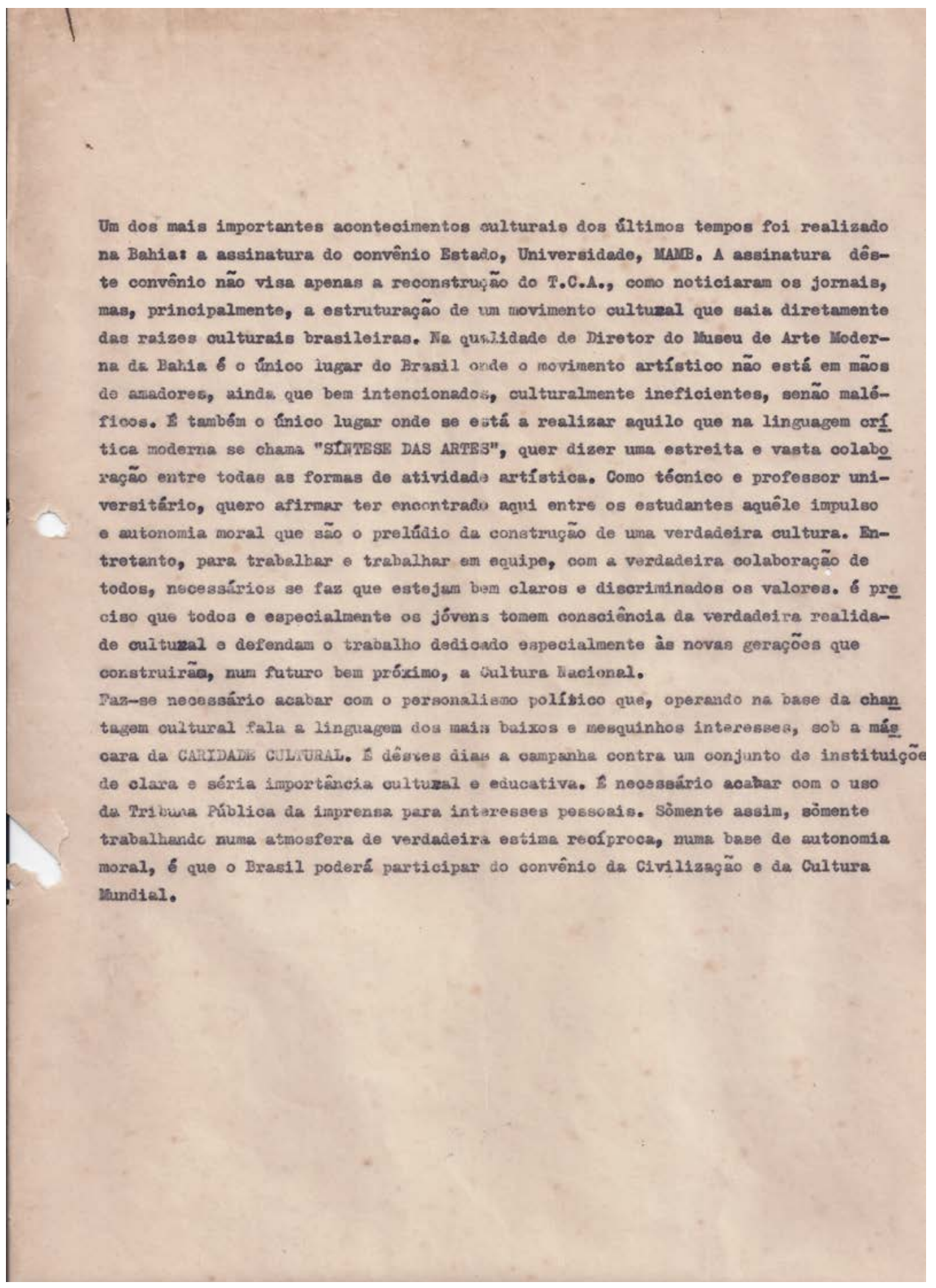

IMG 117.

Texto de assinatura de convênio, s/d, [1960?]. Arquivo MAMB. 


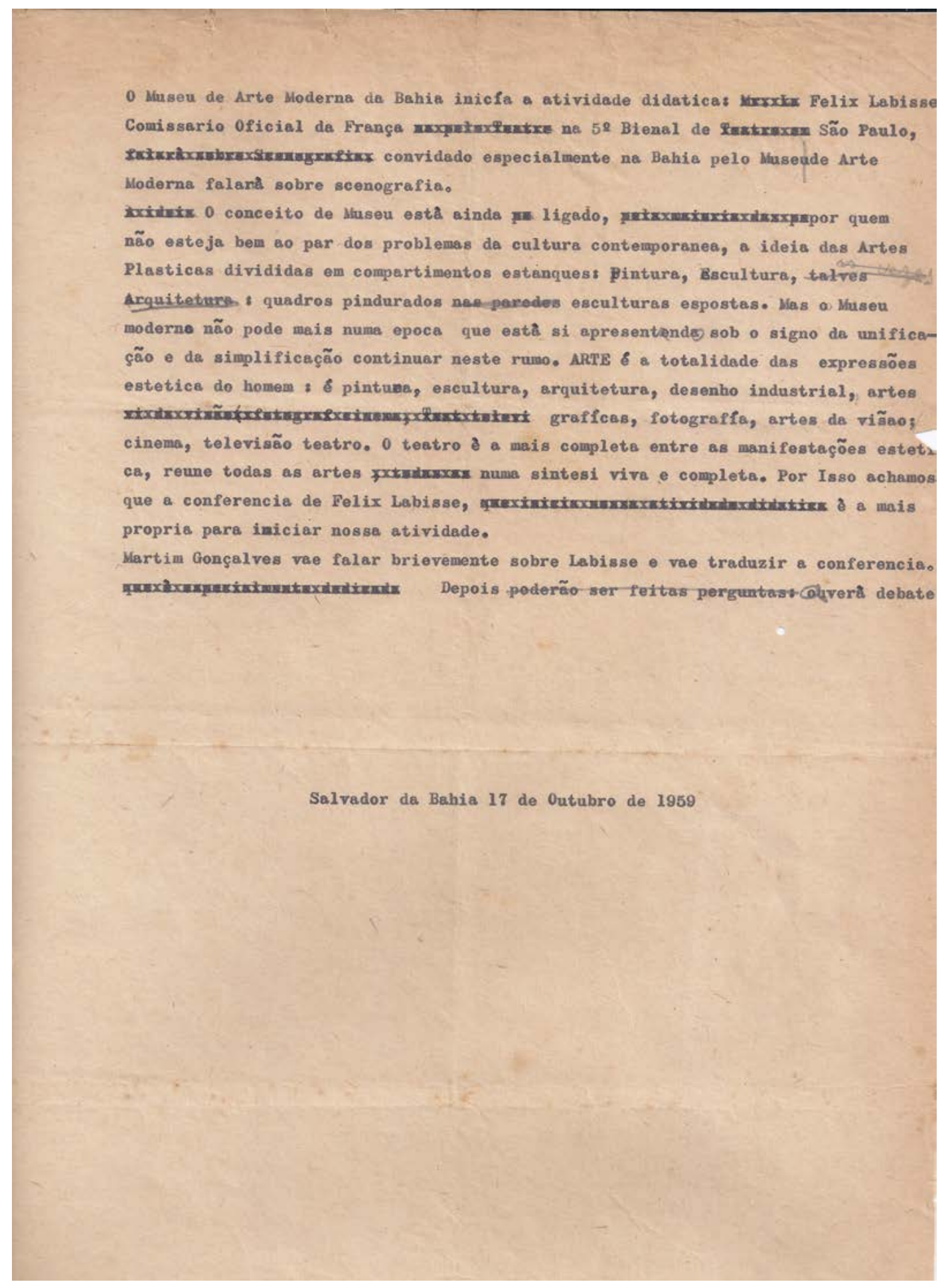

IMG 118.

Felix Labisse. 17 de out. de 1959. Arquivo MAMB 


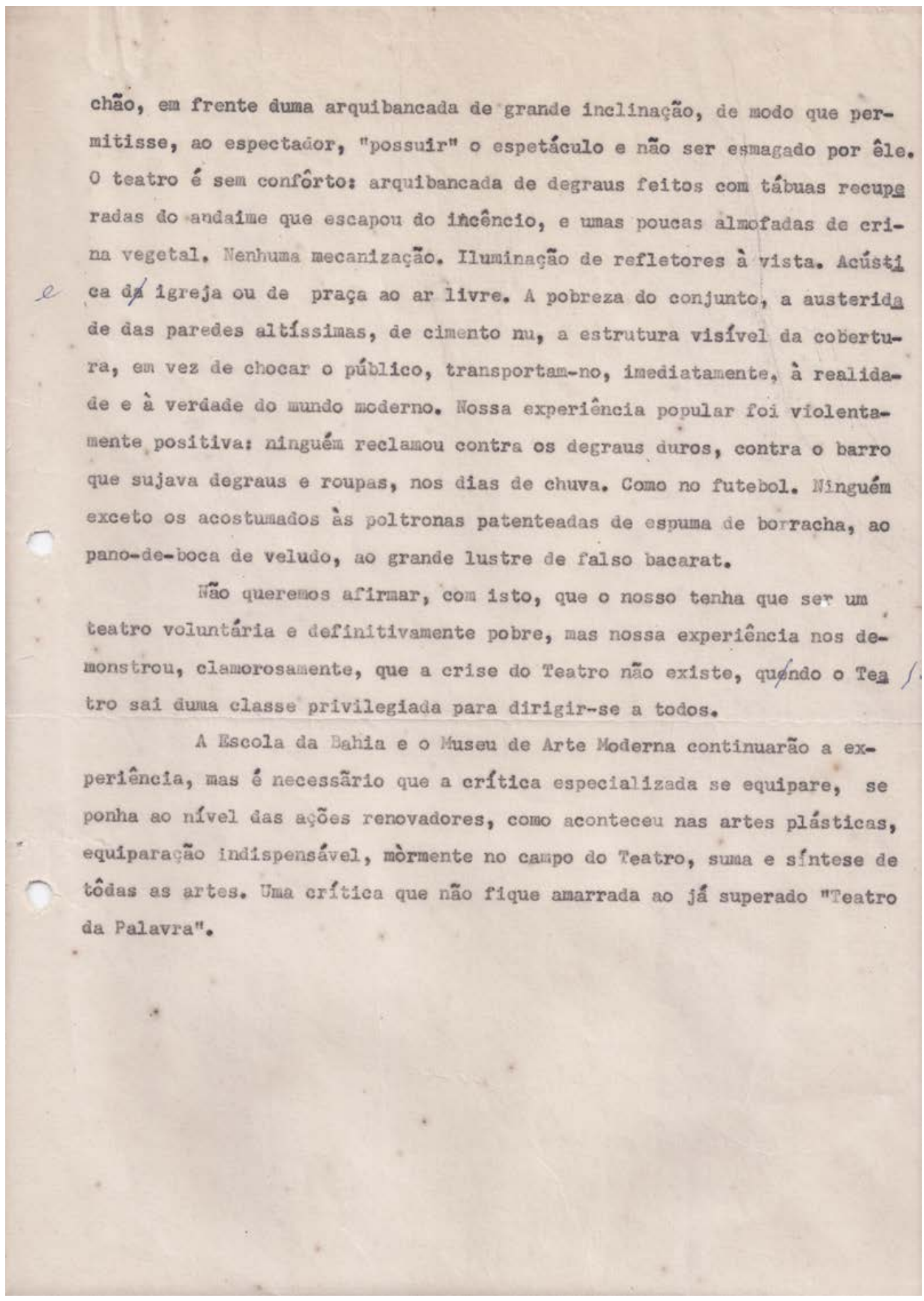

IMG 119.

"Calígula e a crítica teatral". Arquivo MAMB. 
Procuramos reconstruir, como uma experiência (...) o antigo teatro 'côncavo' para conquistar, novamente, a dramática comunicação da cena pública, perdida nos tempos de Teatro de Corte. O estádio esportivo, o circo, são teatros côncavos, com violenta reação recíproca: ação pública. O teatro tradicional, de uma caixa esculpida em duas dimensões, é um teatro 'convexo', cuja ação é afastar-se e isolar: uma pintura a ser vista, sem participação (...) Nossa experiência popular foi violentamente positiva: ninguém reclamou dos passos difíceis, da lama que suja os degraus e as roupas nos dias de chuva. Como no futebol. Ninguém, exceto aqueles acostumados aos bancos patenteados de espuma de borracha, a cortina de veludo, o grande brilho do falso Baccarat". 87

O pequeno teatro improvisado após o incêndio, traria o conteúdo político formalizado em linguagem cênica, cujo aspecto bruto dos escombros na construção de espaços não privilegiados, na contramão do teatro burguês "anti-democrático", ${ }^{88}$ seria capaz de diluir a fronteira entre realidade e representação. "A pobreza do todo (...) a austeridade das paredes altas, do concreto aparente, a estrutura visível do telhado, em vez de atingir o público, transporta-o imediatamente para a realidade e a verdade do mundo moderno". ${ }^{89}$ Tal operação estética, seria identificada anos mais tarde no Teatro Oficina, na cenografia $\mathrm{Na}$ Selva das Cidades, em que resíduos das demolições realizadas em prol do viaduto que esquartejava o Bixiga, ${ }^{90}$ não só seriam incorporados ao cenário como culminariam na própria destruição do teatro.91

Lina faria um projeto para o teatro, aproveitando a inclinação da rampa do foyer do TCA que abrigava o MAMB. Mas, ainda que proposta "não mais como teatro de

87 Lina Bo Bardi, "'Calígula' e a crítica teatral". Arquivo M.A.M.B.

88 Id., Jornal da Bahia, 17 de mar. de 1961.

89 Lina Bo Bardi, "'Calígula' e a crítica teatral". Arquivo M.A.M.B.

90 Ver Marcelo Suzuki. PARECER DO ARQUITETO MARCELO SUZUKI ACERCA DO TOMBAMENTO DO TEATRO OFICINA, 2010.

91 Ver Wisnik. Guilherme T. Dentro do nevoeiro: diálogos cruzados entre arte e arquitetura contemporânea. Tese de Doutorado apresentada a FAUUSP, 2012. 
privilégios, mas como teatro popular", ${ }_{, 2}$ não tenha sido executada, provocou "uma violenta campanha de imprensa e televisão", ${ }_{33}$ na pauta de sua reconstrução, que seria concluída em 1967, pautando a divergência entre os estudantes da UFBA e o diretor da ETUB, Martim Gonçalves, somados aos ataques às obras escolhidas de Brecht e Camus.

Para formação de público no Museu de Arte Moderna da Bahia, Lina centraria esforços para além da atualização de sua pinacoteca, mas na elaboração didática centrada na população por meio de cursos e eventos de natureza artística-cultural. Nos ambientes recriados pelas cortinas do foyer seriam realizadas mais de setenta exposições, ${ }^{\text {" }}$ de assuntos variados e matrizes diversas, a maioria com pequenos catálogos, sempre dotados de reflexões críticas e painéis documentais do autor, em caso de retrospectivas, realizando "uma síntese construtiva daquele período". ${ }^{95}$

92 Croquis reproduzida em Lina Bo Bardi, op. cit. , 141.

93 Lina Bo Bardi. Notas., reproduzida em Lina Bo Bardi , op. cit. , 141

94 Uma Lista de todas as exposições temporárias realizadas entre janeiro de 1960 e dezembro de 1963 consta no livro de Juliano Aparecido, Lina Bo Bardi, Bahia 1958-1964, op. cit. pp. 137-143

95 Lina Bo Bardi, Contribuição Propedêutica ao Ensino de Arquitetura, op.cit., p.40.

Esta oxposição visa alcançar o grande público. A este efeito foi adotado o critério náa excessiva mente erudito. O Museu quer apenas despertar 0 interesso pola História no quadro da vida moderna, _liminando o sistema 'compartimento estanque' táo comum no ensino da História da Arte. A êsse fim os visitantes acharão uma corta liberdade cronológica A China o o Japão por exemplo estão situados perto dos modernos o não junto às civilizaçöes antigas. 0 mesmo acontece com os 'primitivos' o os americanos. Quizemos apontar diretamente as influençás da China o Japão nos séculos XVIII \& XIX o das civili zaçöes assim chamadas primitivas, na arte moderna: Van Gogh foi influenciado pola gravura japonêsa $\theta$ Picasso pela escultura negra. Apresentamos peças o riginais, para dar a idéia "real" das diferontos é pocas. Esta exposiçäo, como dissemos, visa somenté despertar a "curiosidado" polas artes, no observador comum. Queriamos dizer, o interesse pela histó ria no sentido modorno a atual. 
IMG 120.

Textos-parede das

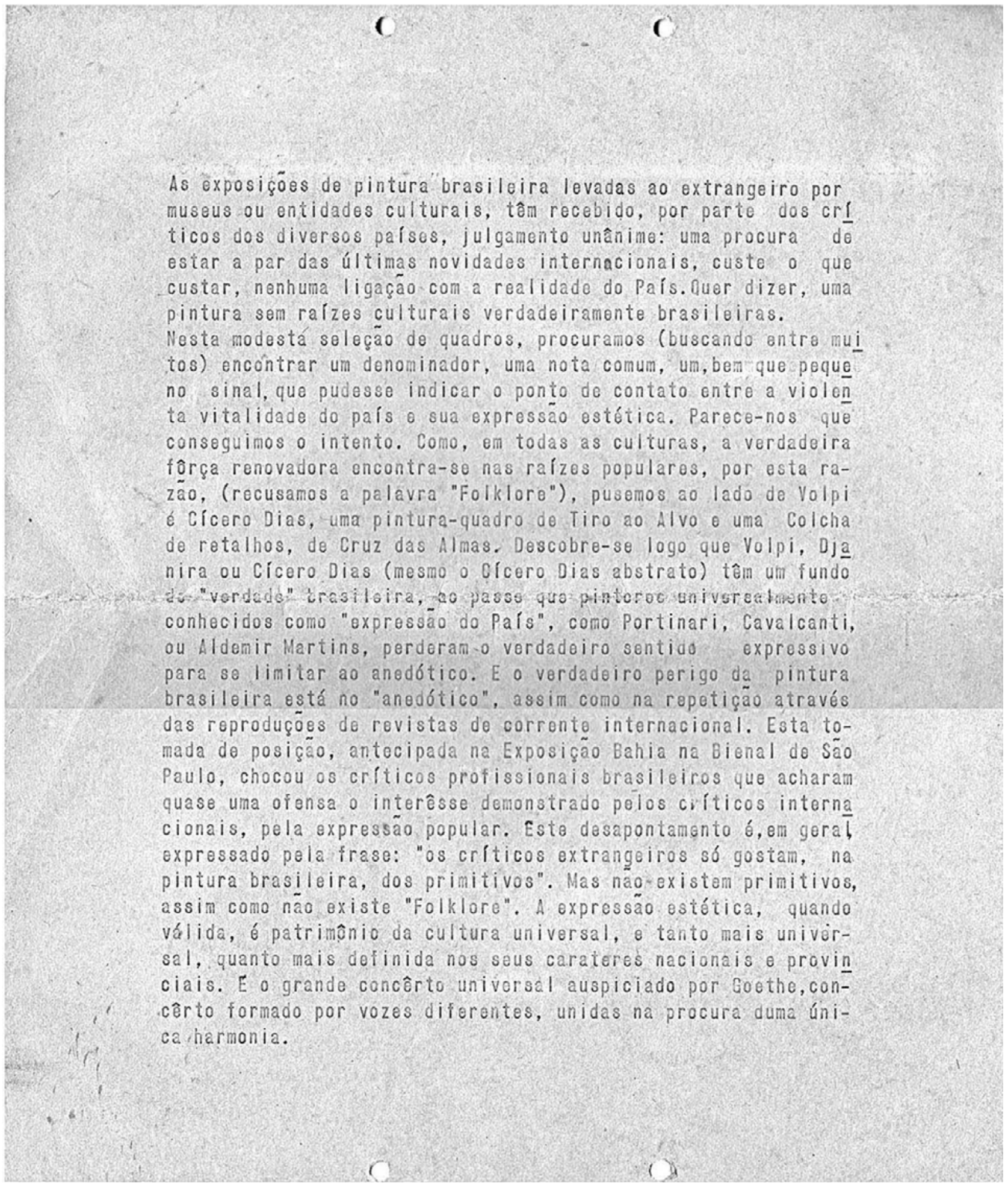


Exposição organizada polo Museu de Arto Moderna da Bahia. O material ilustrativo pertence ao arquivo de docunentaçäo do prof. P.M. Bardi diretor do Museu do Arto de $S_{a}{ }_{0}$ Paulo, bom como objetos originais de oxemplificą̧än das épocas.

Colaboraram na montagom desta exposiçäo:

Jacyra Oswald

Matilde Matos

Maria da Gloria Raiva

Newton Sobral

Ronato Forraz

Sante Scaldaferri

O homem nãa á o mais forte entro os animais, mas é o mais habil: a sua mão é um utensilio. Consoguida uma podra êle ó temível. A história do homem é a história do sou trabal ho. A história maravilhosa do homem é a maravilhosa história da sua mão que corrige a Natureza. A Arto é trabalho, como qual quer outro trabalho. É um trabalho superior. Mas a História da Arte é tamben a História da mão do homem, que traduz materialmente o seu pensamento, a sua autonomia o dignidade de homem. 


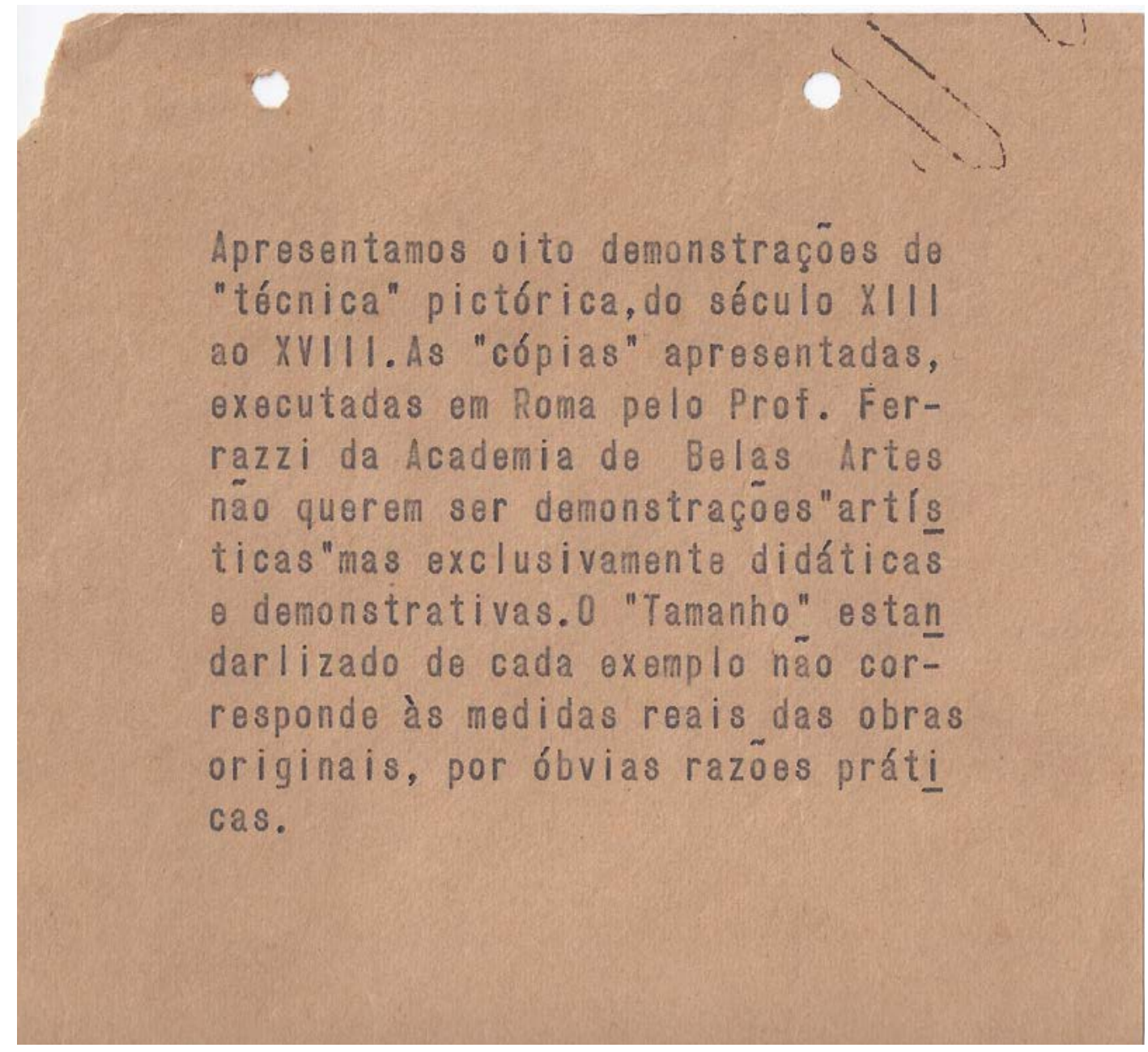


Esta prancha cronológica reassume as principais correntes culturais. Quizemos simplificar a porcepçäo a priori do Oriente o Oci dente e Grécia o Näo-Grécia. Incluimos no Romantismo todo o movi mento moderno e a abertura ao futuro, abribuindo ao romantismo a significação do "particular", do humano, contra a metafísica "universal" clássica. E nesse sentido que tem que ser entendida a definiçęo de "romantismo" dada ao período atual, diferente da do "romantismo" do século XIX, embora no começo do Romantismo do sé culo XIX houvesse a definição do "particular", do humano, çu que perdeu-se em seguida no desespêro e na nostalgla.

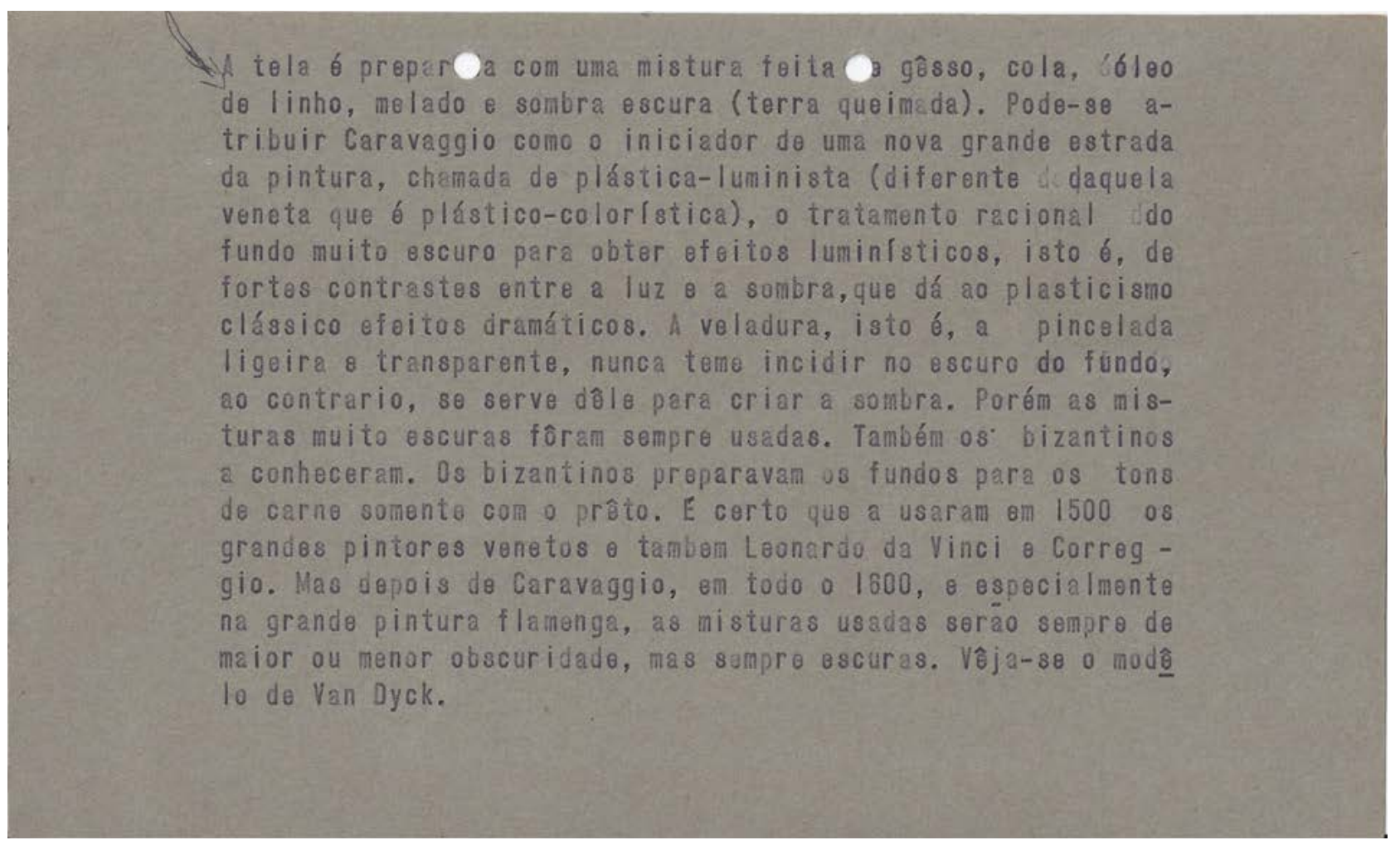




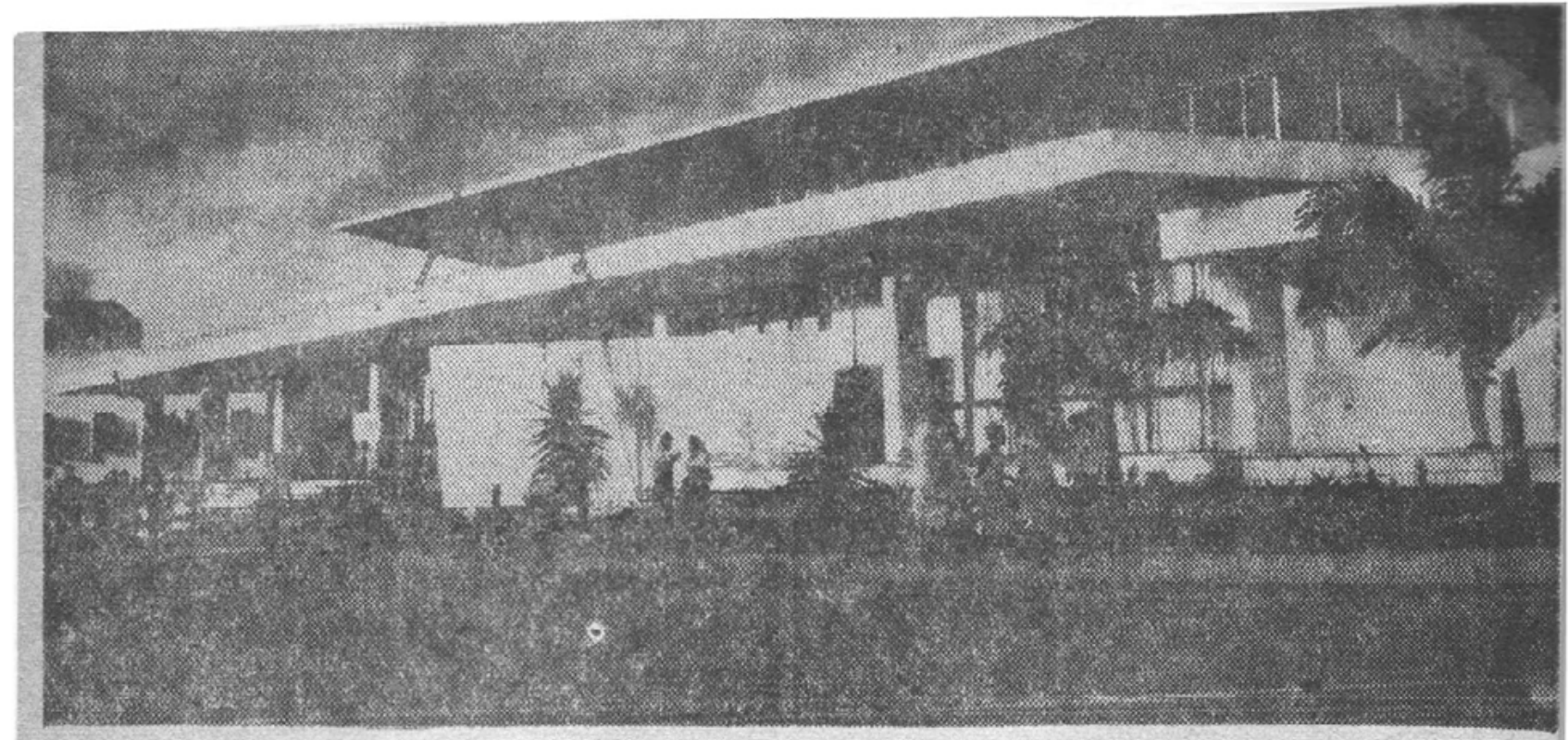

te, como alguns pseudu_marsis. tas mais reacionarios do gue os mais evidentas retarclados mentais, Usa esta islavis, apil ca este térmo diariainente como defesa de uma Bahis ex. polisia.

Conteúdos de um Poro

Os contéudos do povo brasi leiro estáo na Balia. O super. ficialismo critico m!duziu este riqueza a um esgotame:ivo peta abordagem inco. equente, uma insistència flácida.

- Museu de Jite Moderna retoma este perclicio. A axpe. riência já haviam foito Mar. tim Goncalves e Lina Berci com a celebre Exposicáo hia" que ofuscou a ulturo Ba hia que oftuscou a ultnus Bie nal Brasileira e prujetou o Bra. sil nas manchetes dos grandes jorzais o revistas do mundo. Deslambrou a critica interna nacional. Irritou o provincia. nismo paulista, ergue as ban. delras da Banis para muito al $m$ de nossas fronteiras nu ma propaganda de nossa terra jamais feita por qualquer in. telectuai batano. Existia entấ o MUSEU DE ARTE MODER NA em potencial. Desta ideia surgiria a sede precarialnento instalada no Castro Aives Agora, contudo, 0 Governador JM promete a nova secie.

O papel do Governador JM e de sua espôsa, a Sra. Lavi nia, é importantissimo. O Ga vernador já fo: muitrs vezes criticado por vausa du MAMB. Entende, porém, como homem de visáo politica e cultural aberta ao progresso, que am povo náo pode viver sein co nhecerse a si mosmo, na sus sensma cultural moderno. Por isto a Sra. Bardi, apoladia pelo Cto a sra. Bardi, apotada pelo Governacior, abre baterias da bia de Todos os Santos.

\section{Exposições Realizadas: Resumo}

I* EXPOSIÇÃO - Antonio Bandeiro. Pintor brasileiro, natural do Cearé, residindo hé dez anos em Paris. Exposição inaugural do Museu. 21 óleos: 10 gauches de 1959.

$1^{2}$ EXPOSICÃO - Vinte bronze originaís de Edgar Degas. Empréstimo do Museu de Arto de Säo Paulo.

$3^{2}$ EXPOSICÃO - Flávio Shiró Tanaka. Pintor brasileiro de procedênclo japonêsa, pegídindo no Brasil há 28 anos.

4" EXPOSICCÃO - Manabu Mabe. Pintor brosileiro de proeedêneie iaponésa residindo no Brasil desde 1934 em Säo Paulo: 10 gauehes. Waichi Tsutaka. Pintor Joponés recentemente eheqado ao Brasil. 12 óleos.

5" EXPOSIÁCO - "Ver a Pintura". Esto exposicäo de caráter didático teve como principal objetivo a representaçăo da expressắo estética válido e nāo-válida otravés da aprenenta. căo de quadros das díversas tendências até os acadêmicos e "pompier" bem como exemplos de "naturezos mortas" "reais e fotografias".

6" EXPOSICAO - Mário Cravo em Yeneza, Escuifor boíano. Exposicão das escultaras de madeira e ferro quo representaram o Brasil no XXX" sienal de Venexa. 10 esculturas.

$7^{2}$ EXPOSICÃO - Trâs pintores: Renoin, Cozanne Q Van Gogh. Apresentaçóes de aua. dros cedidos por empréstimo do Museu de Arte de Sáo Paulo e reproducōes com textos didáticon.

$8^{*}$ EXPOSIÇÃO - Sete Artistos Baianos: Calazens, Jaeyra, José Maria, Juarex, Osweld, Riolan, Sonte. Exposiçáo óleos e gravuras.

$9^{2}$ EXPOSICÃO - Aldemir Martins. Desenhista Ceorense. 25 b́leos 5 desenhos.

$10^{2}$ EXPOSIÇÃO - Acârvo, Empréstimo (Didática). Nesta Exposicáo, com apresentaęáo de quadros de pintores brasileiros peças do arte sopular, procurou-se focalixar os valores mais auténticos do pintura brosileiro. Confrontando primitivos com pintores "profissionais", apresenton"do calehos de retalhos e táboas de tiro ao alvo.

$11^{2}$ EXPOSICCÃO - Georges Mathieu. Pintor francàs. 28 bleos, 9 gavehes.

$12^{\mathrm{a}}$ EXPOSICÃO - Stanley William Hyter. Gravedor inglês. 17 gravaras o très bleos.

$13^{2}$ EXPOSICÄO - Genam de Carvalho. Pintor baiano. Tapecarias.

$14^{2}$ EXPOSICÃO - Paolo Rissone. Pintor brasileíro de procedéncia italiana. 27 obres entre jicos a quches.

\section{OUTRAS EXPOSICŌES:}

Nós e o Passado - Esto expasięāo vem sendo apresentada ao públice dasde e fundosz̃a do sea havendo apenas a mudanca de auadros exposto - cortina musical. Foram expostos 3 quadeos: Ultimo Mnmento do Banquete de Herodes, do círculo Bonaventura Berlinghieri. Quedro do século XIII, de colecóo P. M. Bardi. Visita da Cámara à Iareia de Graç. Fantasio Araureológiea com Fiquras. Quadro do século XVII de Gean Paolo Paninne. Da colecáo P. M. Bardi.

FORMAS NATURAIS - Exposicão de caráter permanente. Mostra de pedras recolhidas nos praias, formas minerais e vegetais. Com colaboecáo da Bolsa de Mercadorias da Bahia, Ingtituto de Teenologia e do Escultor Mório Cravo.

$15^{2}$ EXPOSICÁO - Teatro Inglês. Exposiccáo de fotogratias de Teatro.

16. EXPOSICAOO - Acêrvo.

$17^{2}$ EXPOSICÃO - Montex Magno. 15 bileos: naturexa morta.

$18^{3}$ EXPOSICĀO - Roberto Burle MarX. Arquitefura - iardim. 
Ao problematizar a historicidade inerente às obras apresentadas em sua diversidade de períodos na agenda dos museus, a formação do olhar seria uma ferramenta pedagógica importante na compreensão do presente artístico, uma vez que "se, ao considerar um trabalho do passado, levarmos em conta o 'ponto', o momento em que foi executado, podemos revivê-lo hoje em sua continuidade histórica, enquanto que, se o encararmos apenas como 'realidade' de hoje, eliminamos a continuidade histórica e perdemos o passado do qual o moderno é o resultado ".96

O caráter didático das exposições estaria na representação das expressões estéticas caracterizadas como válidas e não válidas, como se nota nas referências da quinta exposição "Ver a pintura". Já na décima exposição, o conceito de Exposições Didáticas seria incorporado à agenda pedagógica do museu baiano, onde lê-se nas anotações dos resumos das exposições realizadas no primeiro ano de funcionamento: "Acervos, Empréstimos. Nesta exposição didática com apresentação de quadros de pintores brasileiros e peças de arte popular, procuramos focalizar os valores mais autênticos da pintura brasileira. Confrontando primitivos com pintores 'profissionais', apresentando colcha de retalhos e taboas de tiro ao alvo".

Das exposições permanentes: "Formas Naturais", em parceria com a Instituto de Tecnologia e colaboração de Mário Cravo Jr., a partir de "pedras coletadas nas praias, formas minerais e vegetais", $\mathrm{e}$ "Nós e o Passado", que apresentaria em correspondência duas obras antigas de matrizes diversas, sendo uma plástica e outra musical, a partir da coleção de Pietro Maria Bardi, "Último momento do banquete de Heródes", pintura do século XIII do círculo Bonaventura Berlinghieri, e outra do século XVII, "Visita a câmara da Igreja da Graça", de Gean Paolo Paunini. ${ }^{98}$

$O$ conceito de escola no seu sentido imediato abrigaria a "Escola das Crianças", entre atividades lúdicas de pintura e escultura, passando ao teatro, e a "Escola de Música Infanto-Juvenil", ambas para o público de 4 a 12 anos, abrindo espaço no currículo conservador do ensino tradicional, no sentido de "integrar a criança no ambiente de seu mundo e criar condições para o seu equilíbrio psicológico através do contato com Arte"."

Entretanto, se a liberdade do estatuto de fundação possibilitou o seu trânsito para além das amarras do Estado, na medida em que seu projeto antiacadêmico de emancipação cultural se afastava do patrimônio provincial baiano, consolidando uma frente de ação popular mais próxima das vanguardas, o Museu tornou-se objeto de disputa e, internamente, o projeto político pedagógico de Lina teria que resistir inclusive na base de seus apoiadores iniciais.

Assim, logo ao assumir a direção do MAMB, Lina percebeu que "a inércia conservadora do Sul poderia ser superada no campo cultural, pela 'tensão' dos estudantes e pelo caráter fortemente popular do Nordeste." ${ }_{100}$ De antemão almejava a realização da Primeira Bienal Nacional

\footnotetext{
96 Lina Bo Bardi, "Museu de Arte Moderna da Bahia", em Lina Bo Bardi, op. cit., 139.

97 Lista de Exposições realizadas no MAMB, arquivo MAMB. Grifo da autora.

98 Lista de Exposições realizadas no MAMB, arquivo MAMB.

99 Lina Bo Bardi, Entrevista cedida ao crítico literário Leo Gilson Ribeiro. Jornal do Brasil - Suplemento Literário, 17 dez. 1970.

100 Lina Bo Bardi, "Cinco anos entre os 'brancos'", Mirante das Artes, Etc. 6, op. cit.
} 


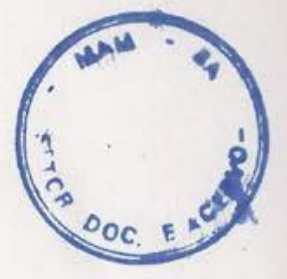

- kusseu de Arte Hoderna da Bahia, criado pela Iel 1252 de 23 de Julho de 1959, Inmagurou-se solenemente em 6 de janelro de 1960.Recebeu do Govêrno de Eatado uma doação de cinquenta milhōes de cruzeiros em apb11.es, que constituem o seu patrimônio - cujos juros custeiam suas aty.vidades.Tem realizado atहै a data vinte sete exposiçōes.

sus direçẽo tem buscado atingir, ale̊m das atividades puramento de conservação, finalldades educativas e difusoras da cultura.Prova disso são a Fseola da Criança a Fscola de khisica Infanto-Juvenil, as quais coń a colaboreção da Universidade da Bahia e a assistência do Museu, vêm funcionando desde o segundo semestre dêste ano. Uma centena - meĩ de orianças de 4 aоs 12 anos frequentam os seus diversos cursos, às qua1s, mอnо que uma Inicisção artlstioe se tem procurado fornecer os mejos de desenvolvimento da personalidade stravés da Arte. Tal procedimento tem frutificaco com a icrnação de uma equipe que permitirá om futuro próximo, e em colaboraça com instituiçōes que se dedieam ao enalno técnico, a criaçẽo de ume Universidade fopulax, laboratório de pesquisa e criaçäo de objetos - padrĩo quo deverá suprir as neceasidades da industria necional. No ano de 1961 será res.lizada também a l* Bional

- Nacioral 
A denúncia solitéria, sem consequência, 6 burguêsa. 0 humanitarismo como pie dade abstrata anheiros de luta. Sartre chama suall+ acuando-o de um desvio para a direita E moral "uma moral de Cruz Vermelha", acuạndo-o de um dosvio pa da reação.Camus de um amblguo "abracemo-nos" aplaudido pela direita a somba responde: se a verdade estivesse na direita eu estaria all. o anti-colonialis lO homem da resistência, o corajoso articulista de "Combat", oraço dilacerada ta defensor dos algerianos oprimidos, o lider de toda uplo", a trangferêncial+ pela guerra, reduzida à necessidade lúoida do "jogo-duplon, a transerinio orda Pátria e da honra de um campo para o outro, espectadora do aet Camus decla ganizado e da destruição de todos os valores, o revoltado Albert Cava o "senexcell ra de súbito passada a época dos "furores adolecentes", relvinâbre a Revolta"|so de medida" e pronunciava encerrado o romantismo. A "Carta \& uma dolorida resposta aos ataques violentos dos seus conpentemente: "Vocês||+ às acusações de profissão idealista, Depois de 1951 Camus, o homem público mantem-se calado por dez anos. Quandol+ morre, em 1961, Sartre escreve para êle as palavras mais sérias que pode ing pibar a morte de um homem de verdade e - no seu protesto apaixonado contra a injustiça dessa morte que truncava uma obra impondo a necessidade repentina|+ de julgá-la concluida - dizia: "êle teria falado". 0 absurdo e a revolta, te mas constantes da sua obla, vividos pelozhomem Camus na realidade da guerra|+ e da Resistência, deveriam, inevitavelmente, levá-10 à busca de uma separaçãa|a uma conclusão humana. E a essa pesquisa, sem preconceitos, Camus se dedicou, $\mid-$ renunciando, ao lado mask belo dê sua figura de homem de ação e de pensamento: a aparência violenta e revolucionária, sua imagem que a juventude estima va. E se algo é claramente favorável a Camus, como homem, na polemica de 1951/("O Homem Revoltado - Tempos - Modernos") \& esta sua voluntária renúncia a $\underline{u}$ ma posição extremamente válida no quadro da cultura moderna - a de progres-1+ sista para chegar à qual o intelectual contemporâneo as vezes se ergue até $\mid+$ os compromissos extremos. Hoje, a dez anos de distância, a posição de Camus|+ é clara, clara sua lúcida renúncia ao privilégio da sua posição revolucionária que the teria imposto uma "lateralidade", ao passo que em Sartre se nota claramente a preocupação de não querer perder por prêço algum tal posiç̃o. ||$+$ Mas Sartre tinha razão, se bem que fosse uma razão contingente. Era cêdo demais. Cêdo demais para uma imparcialidade histórica, cêdo demais para a rei-. vindicação de valores puramente humanos. Hoje mesmo ainda é cêdo demais. Perante a morte de Camus devemos dizer, hoje, que êle já falou. $\mathrm{B}$ a história do|homem começou a responder: por traz do "amor do distante", por traz do "nos $\mid+$ seremos", que Camus queria transformar de repente em "nós somos", por traz|q+ da frieza aparente do mundo técnico, uma nova era começa a despontar: Icaro, já não mis querendo igualar-se a Deus, procura pôr termo ao silêncio entre|+ os homens e rejeita a felicidade se não pode sentir-se tranquilo quanto a to dos os seus irmãos. Superada a contigência, as palavras de Camus assumem ol|+ seu verdadeiro sentido: "para além do nihilismo, nós todos, entre as ruinas, preparamos uma renacenç". Numa nova cultura livre dos fantasmas dos mitos, $\mid+$ - homem poderá vover e construir, embora jamais se anule a sua melâncolia, ||$+$ conciente que é da Natureza e da Historia.

I $B$. 
- "Anti-bienal" - ${ }^{101}$ para o ano de 1961, além da "formação de uma equipe que permitirá em futuro próximo, e em colaboração com instituições que se dedicam ao ensino técnico, a criação de uma Universidade Popular, laboratório de pesquisa e criação de objetos-padrão que deverá suprir as necessidades da indústria nacional." "102

Glauber Rocha escreveria em 1960, que a "Universidade popular seria a valorização dos nossos costumes objetivos (das nossas práticas, como a cerâmica, artefatos, escultura e pintura primitiva) elevados à condição de elementos úteis a uma sociedade em desenvolvimento", uma "pretensão [...] de vanguarda dentro de um Estado". ${ }^{103}$ O cineasta via na "estética da fome" uma política paternalista que, quando não ignorava a realidade profunda do Brasil, lançava mão de um estereótipo fundado no exótico, base de um "colonialismo cultural", antônimo da autenticidade - "na força da cultura que explora" - reivindicada no processo de conscientização, necessário para projetar um sistema cultural complexo. ${ }^{104}$

101 Id., "'Calígula' e a crítica teatral". Arquivo M.A.M.B. Onde lê-se: "Texto para a expos. da Bienal".

102 Resumo das Atividades do Museu de Arte Moderna da Bahia. Arquivo MAMB, s/d., escrito por volta de 1960. Em relação à Bienal, em 20 de março de 1961, Lina menciona em entrevista local que a Bienal estava prevista para maio de 1962. No entanto, a mesma só ocorreria em 1966, quando Lina já se encontrava desligada do Museu.

103 Glauber Rocha. MAMB não é Museu: é

Escola e "Movimento". Por uma arte que seja desligada do Homem, op. cit.

104 Id., "Uma estética da fome", Revista Civilização Brasileira, n. 3, jul. de 1965. 


$$
i
$$


PRÁTICAS

PEDAGÓGICAS

\section{MAPU}

\section{Arte com A maiúsculo}

\begin{abstract}
Arte popular é o que mais longe está daquilo que se costuma chamar Arte pela Arte. (...) nesse sentido, é o que mais perto está da necessidade de cada dia: NÃO-ALIENAÇÃO, possibilidade em todos os sentidos. ${ }^{1}$
\end{abstract}

O Museu de Arte Popular se tornaria um projeto em 1960 e abriria suas portas no Solar do Unhão, em 1963. Assim como o MAMB cujo projeto visava a ser mais do que um museu para conservação, o Museu de Arte Popular nasceria sob o mesmo ímpeto pedagógico de fomentar um sistema de produção de matriz popular em relação ao desenvolvimento do país em direção a sua independência cultural.

O embate contra o termo folclore estaria no catálogo da exposição Bahia, ${ }^{2}$ em 1959, e sua aplicação deriva de um sentimento romântico de visão de classe em relação à cultura popular, na contramão de sua autenticidade, através de uma "herança estática e regressiva", ${ }^{3}$ forjada por "turistas e damas", por meio de um julgamento paternalista que obliterava o conflito resultante do abismo entre classes.

1 Id., "Arte popular e Pré-Artesanato Nordestino", op. cit., p. 25.

2 Id. e Martim Gonçalves, "Apresentação", Bahia, Exposição no Parque Ibirapuera. O debate sobre o folclore e sua matriz reacionária já se fazia presente suas atividades na revista A, em 1946, ainda na Itália. Ver artigo "In cerca di mobili", A Cultura della Vita, n. 9 (8 de junho de 1946).

3 Lina Bo Bardi, "Civilização do Nordeste", em Tempos de Grossura: o design no impasse, op. cit., p.37.

4 Id. "Por que o Nordeste?", em Tempos de

Grossura: o design no impasse, op. cit., p. 20. 


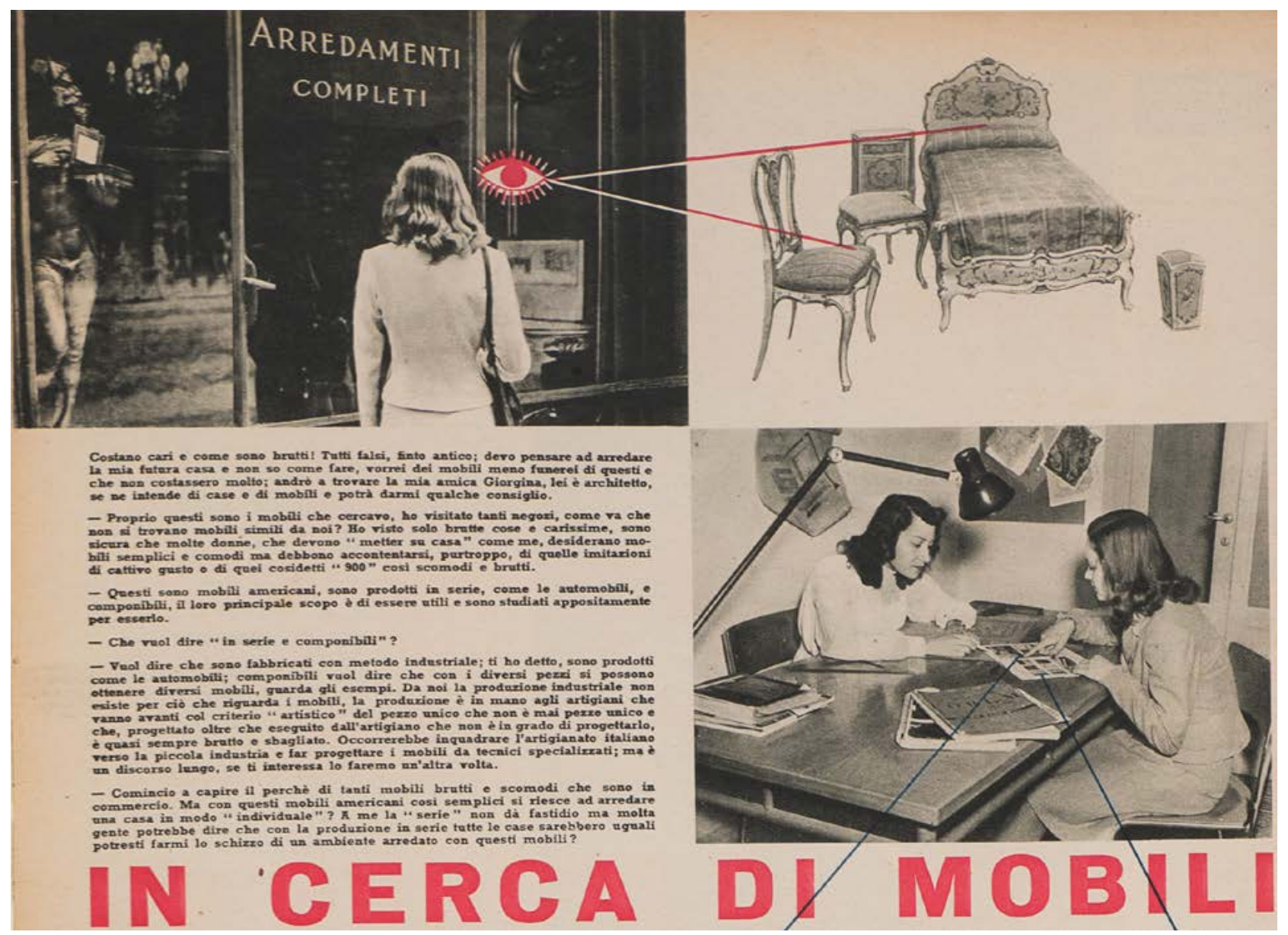

IMG 125.

"In cerca di mobili", A Cultura della Vita, n. 9, 1946. Foto Kipnis. Acervo Grinover
Ciente do perigo de regulamentar a estética, nela intervindo administrativamente, sob o risco de afirmação de ideologias superadas, Lina se colocaria contra as políticas autoritárias de Estado, de viés nacionalista, como o culturalismo fascista, que ensejava uma pseudocultura ao projeto nacionalista, cujos desdobramentos eram reconhecíveis em derivações sob nomenclaturas diversas, que petrificavam o conceito de cultura no mundo ocidental. Nesta chave, estariam "o 'Pueblo Español' do Generalíssimo Franco, (...) as 'Rendeiras Portuguesas' do Dr. Salazar, (...) o "Strapaese" do P.N.F. (Partido Nazionale Fascista)". ${ }^{5}$ A Europa, produziria a partir desse "protecionismo paternalístico que originou os 'pueblos' e 'Instituti d'arte artigianalí', verdadeiros museus de horrores e catálogos de espécies inomináveis".

Quando a produção popular é petrificada no folclore (...) as raízes culturais verdadeiras e suculentas de um país secam: um sinal de que 'interesses' internos ou de importação assumem o poder central e as possibilidades da cultura autóctone são substituídas por 'frases feitas', por 'supino' repetição 'e o final de fixação para os regimes de esvaziado. É o caso do italiano popular, petrificado pelo Fascismo. Não foi o folclore que desapareceu - foi a alma popular que desapareceu.?

A mesma perversidade dos efeitos da cultura amparada no folclore seria direcionada à produção dos gadgets, "na maior parte supérfluos (...) na situação cultural do país,

5 Lina Bo Bardi, catálogo de exposição "Caipiras, capiaus: pau-a-pique", realizada no S.E.S.C. Pompéia, em 1984

6 Id. "Arte industrial", Diário de Notícias, Salvador, 26 de outubro de 1958

7 Ibidem. 
criando barreiras, impedindo o desenvolvimento de uma cultura autóctone". ${ }^{8}$ As implicações da cultura em massa e das necessidades projetadas pelo consumo eram especialmente danosas em países sem um projeto próprio definido, para os quais a entrada dos objetos inúteis "confortavam" o esforço desesperado de cultura. ${ }^{\circ}$

Não menos problemático seria o termo artesanato, a partir da formulação da existência não de um corpus social regulamentado oficialmente por uma corporação, aos moldes do Velho continente medieval, mas do proletariado artesanal. ${ }^{10}$

As razões para consolidação da precariedade desse sistema artesanal, que Lina atribuiria como "pré-artesanal" seriam diversas e acumulativas, desde o preconceito social de sujeição ao trabalho num país escravocrata à predominância de uma economia rural fundada na exploração do homem e da terra. Assim, o artesão/ "pré-artesão" ocuparia a posição intermediária entre o senhor e o servo, e seu trabalho estaria igualmente sujeito à concorrência de um sistema de produção pautado no trabalho escravo." É importante frisar que as precárias corporações que existiam no Brasil foram abolidas na Constituição brasileira de 1824, subsistindo nas áreas urbanas e rurais como pequenos grupos informais e, portanto, desamparados social politicamente em seu "pré-oficio" de caráter doméstico, herdeiros dos engenhos de açúcar. ${ }^{22}$

Em oposição ao "folklore popular", a arte popular derivaria de uma "atitude progressista da cultura popular ligada a problemas reais", ${ }^{13} \mathrm{e}$, portanto, dotado de ação, daí o conteúdo político do termo popular adjetivado na palavra arte. Nas páginas de Habitat, Lina ressaltaria a autenticidade de seu valor artístico, pela ética humana que incorporava, da reação do povo à miséria e, portanto, moderna em sua adesão à realidade, ${ }_{14}$ - "Arte com A maiúsculo" ${ }^{15}$

8 Lina Bo Bardi, "Um balanço dezesseis anos depois", op. cit., p.11.

9 Id., "Por que o Nordeste?", op. cit., 24

10 Id., "Discurso sobre o significado da palavra artesanato", op. cit., pp.16-18.

11 Ver José Carlos da Costa Pereira, Artesanato e Arte Popular, 1957, op.cit., pp. 27-28.

12 Lina Bo Bardi, "Um balanço dezesseis anos depois", op. cit., p. 12.

13 Id., "Civilização do Nordeste", op. cit., p.35.

14 lbidem.

15 Lina No Bardi, "Arte industrial" Diário de Notícias, Salvador, 26 de outubro de 1958.
IMG. 126.

O bívio.

[Malasartes. 1976]

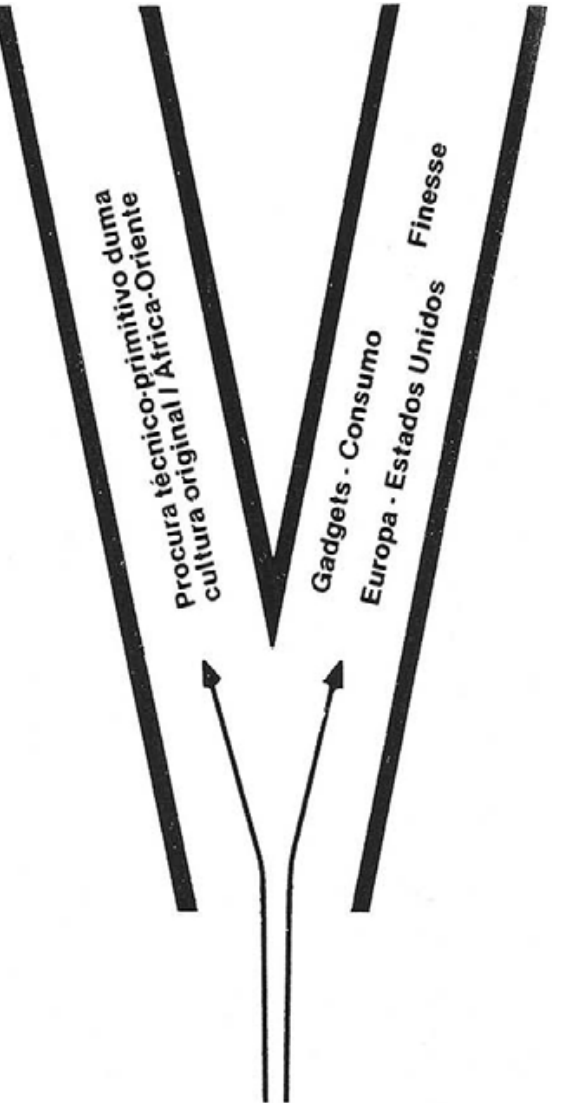

IMG 127.

Revista [Habitat, n. 1:77]

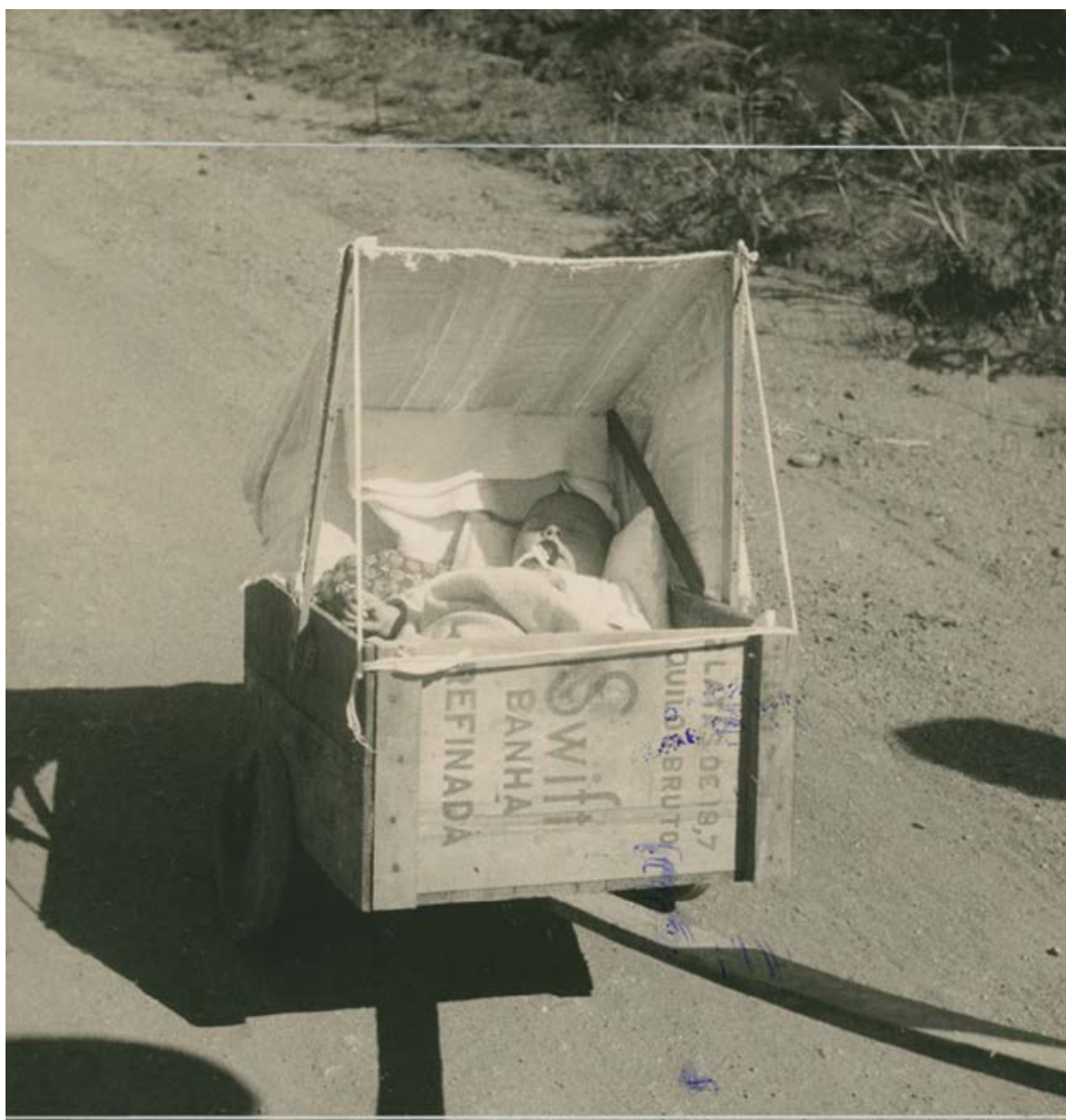




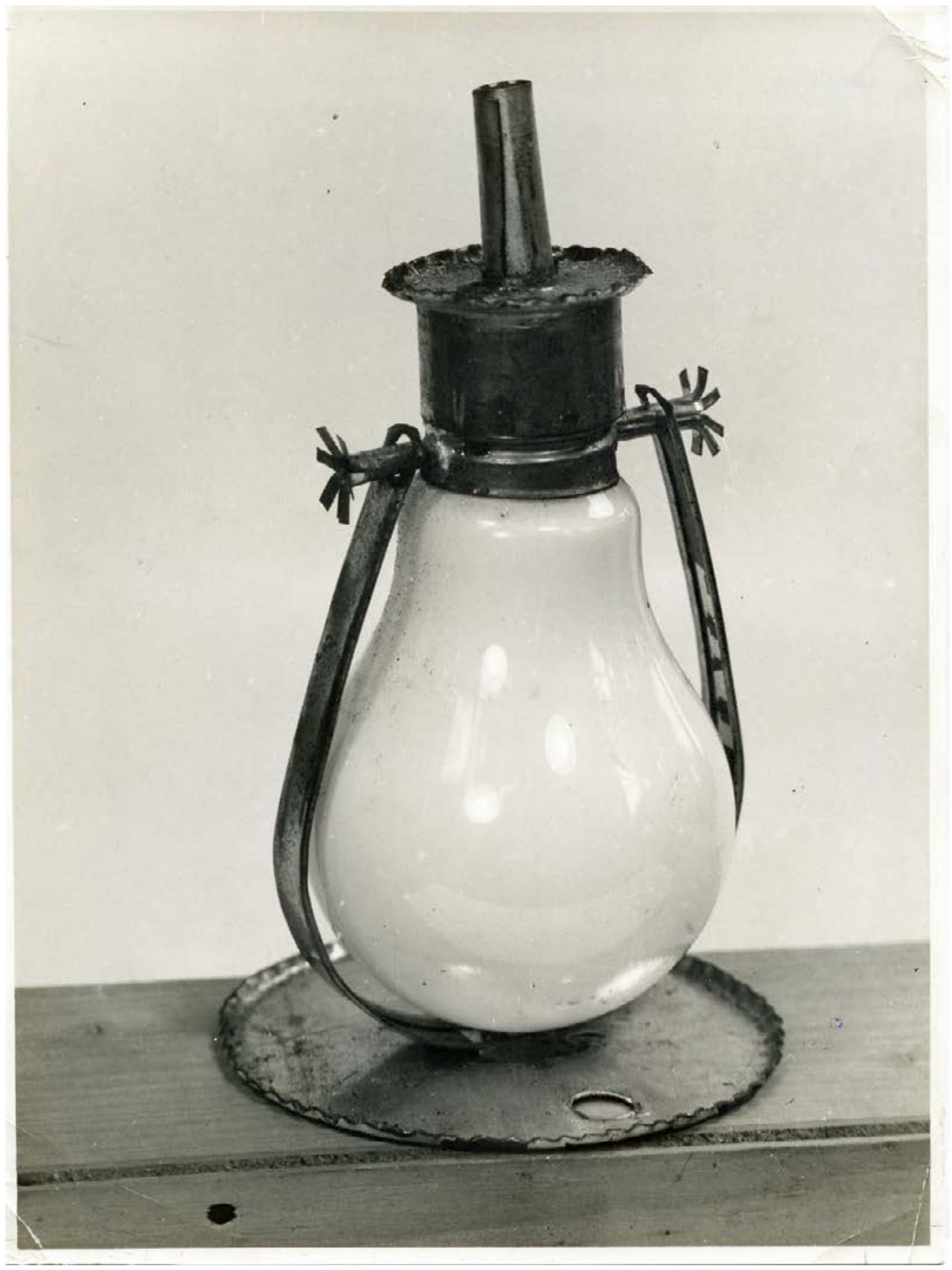




\section{Práticas culturais e populares ligadas ao mundo artesanal}

Procurar com atenção as bases culturais de um País, (sejam quais forem: pobres, míseras, populares) quando reais, não significa conservar as formas e os materiais, significa avaliar as possibilidades criativas originais. Os materiais modernos e os modernos sistemas de produção tomarão depois o lugar dos meios primitivos, conservando, não as formas, mas a estrutura profunda daquelas possibilidades. ${ }^{16}$

Do "conhecimento que se faz no ato", a economia foi o campo escolhido por Celso Furtado que unia pensamento e ação na sua figura de homem público. ${ }^{17} \mathrm{O}$ economista observaria que na esteira do modelo de desenvolvimento adotado, não havia desenvolvimento social correlato, inalterando "as condições de vida de três quartos da população do país", cuja "principal característica foi uma crescente concentração social e geográfica de renda". ${ }^{18}$ Assim, o desenvolvimento se associava a um aumento das disparidades regionais, com seus investimentos em produção de bens

16 BARDI, Lina Bo. "A arquitetura e o artesanato popular ", em Tempos de Grossura. São Paulo: op. cit., pp 20-24.

17 "Queria inicialmente ser romancista, ficcionista. A minha grande leitura até hoje é literária. A descoberta que faço do homem é através da literatura, nunca pela ciência. As ciências sociais são métodos de reduzir, e o homem só se capta totalmente. E é preciso inventá-lo". Celso Furtado em D'AGUIAR FURTADO, Rosa Freire (org.) Ensaios sobre cultura e o Ministério da Cultura. Arquivos Celso Furtado. Rio de Janeiro: Editora Contraponto/ Centro Internacional Celso Furtado, 2012, p.198

18 Celso Furtado, A Pré-Revolução Brasileira, op. cit.,1962, p.14. 
IMG 129.

Celso Furtado em viagem da Sudene. [RISÉRIO, 1995: álbum].

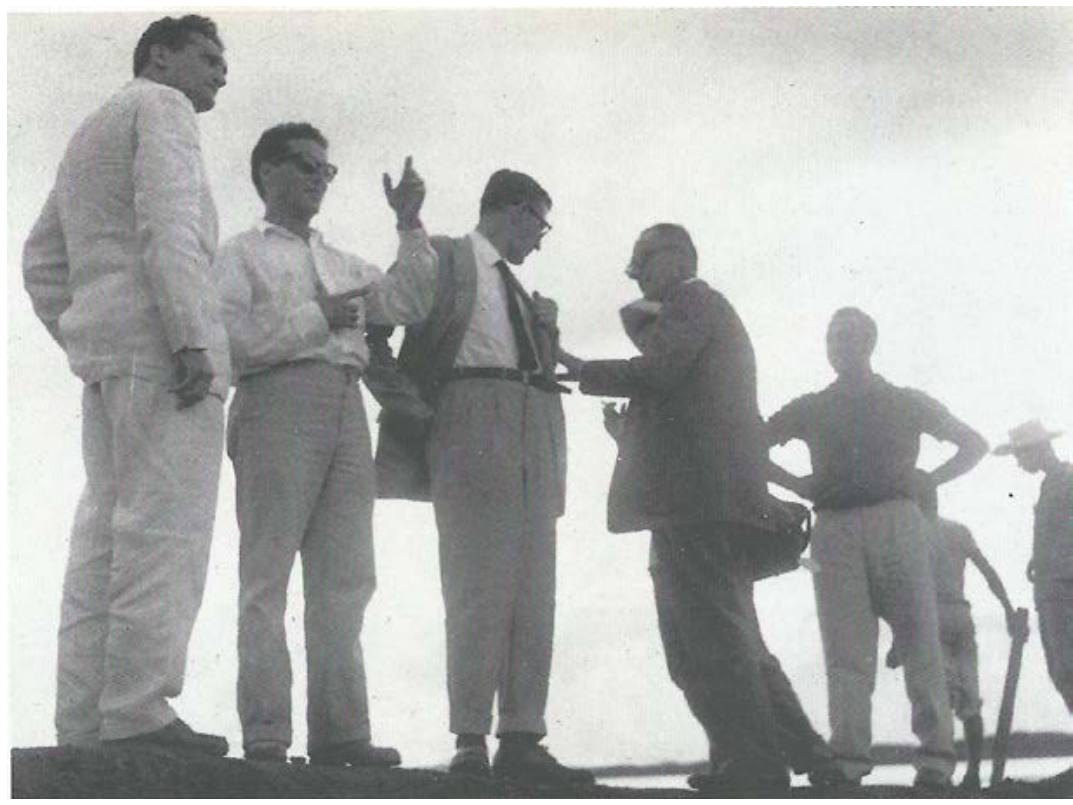

duráveis concentrados na parte sul do país, deixando de lado grande parte do país que, ao estar fora do eixo de desenvolvimento, correlatamente também estaria fora dos sistemas de produção e consumo.

Celso Furtado via na industrialização uma alternativa para o atraso nordestino, entendo que as implicações do progresso tecnológico serviram mais para modernizar hábitos de consumo do que para transformar processos produtivos. ${ }^{19} \mathrm{O}$ relatório traçado em 1959 na Operação Nordeste, apontava para a região um duro prognóstico. Em suas palavras, sintetizaria:

O panorama da economia do Nordeste é totalmente diverso: ao término do próximo decênio, se permanecerem as tendências atuais, sua população será superior a 26 milhões, a pressão sobre a terra aumentará, a vulnerabilidade às secas será maior e nenhuma modificação de importância terá ocorrido em sua estrutura econômica. Então, mais do que hoje, o Nordeste figurará como a mais extensa e mais populosa zona subdesenvolvida deste continente. [FURTADO, 1959:21].20
Na leitura de Celso Furtado, o sentido pré-capitalista da colonização portuguesa no Brasil inaugura o processo de subdesenvolvimento, alavancado pela submissão do país aos interesses forâneos que vão subverter a ordem anterior.

Tem sido pouco assinalado por nossos historiadores o fato de que o século XIX foi em grande parte responsável pelo atraso econômico que acumulamos. Nossa história colonial está marcada por dois ciclos de grande prosperidade: o do açúcar e o do ouro. Ora, no último quartel do século XVIII tem início uma prolongada fase de dificuldades econômicas e transtornos políticos. É a época em que se inicia na Inglaterra a Revolução Industrial, que repercutirá profundamente no sistema de divisão internacional do trabalho. No período de estagnação econômica, que se estende até meados do século seguinte, define-se a situação de subdesenvolvimento que prevalece em nosso país até hoje. ${ }^{21}$ (FURTADO, 2012).

19 Celso Furtado, Análise do "Modelo" Brasileiro. 6ª ed. Rio de Janeiro: Editora Civilização Brasileira, 1978, p.11.

20 FURTADO, Celso. Uma política de desenvolvimento econômico para o Nordeste.

SUDENE. Rio de Janeiro: Departamento de Imprensa Nacional, 1959.

21 Em um texto que nomeia como Machado de Assis: contexto histórico, Celso Furtado discorre sobre o século XIX. Em FURTADO, Rosa Freire d'Aguiar (org.) Ensaios sobre cultura e o Ministério da Cultura. Arquivos Celso Furtado. Rio de Janeiro: Editora Contraponto/Centro Internacional Celso Furtado, 2012, pp. 145-146. 
Distante do mundo medieval reivindicado por Gropius como referência de uma organização coletiva, Celso Furtado no texto, Quem somos? Sete teses sobre a cultura brasileira, condensa no barroco, ${ }^{22}$ a síntese da cultura brasileira:

O ciclo barroco brasileiro constitui quiçá a última síntese cultural no espírito da Europa pré-Renascimento. [...] O quadro histórico em que se forma o Brasil - articulação precoce do Estado com a burguesia em Portugal e total domínio da sociedade colonial no universo europeu pré-renascente. Daí que se possa dizer com razão ser o Aleijadinho o último grande gênio da Idade Média. Importa assinalar que, à semelhança da síntese medieval europeia, o barroco brasileiro era expressão da sociedade como um todo. Sua mensagem atingia senhores e escravos.23 (FURTADO, 1984).

A presença de Celso Furtado e Lina Bo Bardi no Nordeste demonstra um projeto em escala nacional de superação do subdesenvolvimento cujas ações dependiam do desenvolvimento dos estudos sobre a realidade política econômica do país. É nesse contexto de um projeto de uma política pública regional pensada no âmbito federal, que a experiência de Lina está colocada, sinalizando práticas culturais e populares ligadas ao mundo artesanal.

No contexto de desenvolvimento social, em que o Estado assume uma postura de indutor do desenvolvimento em amplo espectro, por meio de um projeto modernizador para além do setor industrial, Lina conferia a predisposição em olhar para o popular como cultura e não como folclore, pensando as possibilidades abertas pelo desenvolvimento industrial do país, vislumbrando um lugar central para a produção em questão. Como ressalta Risério, "o objeto popular é visto em sua inteireza e dignidade. Respeitado como trabalho humano e como solução criativa diante de um certo problema e a partir de determinados materiais". ${ }^{24}$

$\mathrm{Na}$ história dos últimos 60 anos, todos os países latino-americanos, sob diferentes correntes políticas têm convergido na formulação e implementação de políticas de desenvolvimento. Mas só em casos excepcionais foi considerada a necessidade de incluir o desenho industrial nesta política, para não mencionar o design gráfico ou comunicação visual. Não se reconhece ainda que as políticas de desenvolvimento que não considerem o componente projetual estarão incompletas e tenderão, no máximo, a um êxito parcial. Mas, frente às consequências alarmantes do sistema de produção e consumo, impõe-se a necessidade de revisar o modelo de desenvolvimento vigente. Já não se trata de imitar, com o atraso no tempo, o modelo de desenvolvimento dos países centrais, mas desenvolver um modelo menos intensivo no uso de recursos, sobretudo os energéticos, e traçar novos caminhos para o que é chamado de "prosperidade sem crescimento" - uma idéia que é anátema para as correntes dominantes da economia, cuja lógica não registra a possibilidade de colapso do sistema biótico e social. ${ }^{25}$

As discussões entre Celso Furtado e Lina, formalizada pelas correspondências, evidenciam a divergência no entendimento da produção popular. Furtado via na valorização do artesanato a manutenção do status quo da pobreza, enquanto Lina, antevia na forma ética do trabalho popular, não como produto final, sentenciado às origens que o produziu - recusando os "fatores de rigidez na própria estrutura social", ${ }^{26}$ mas como um processo possível em direção a um método didático capaz de transposição

22 Sobre o Barroco, ver BEZERRA DE MENEZES, Eduardo D. O barroco como cosmovisão matricial do êthos cultural brasileiro. Revista Ciências Sociais, vol. 39, n. 1, p. 49-77, Fortaleza, 2008. "[...] em nossa formação sócio histórica como povo e nação, não possuindo um período medieval, surgimos, de plano, em meio à florescência dominante, durante pelo menos dois séculos, do Barroco; encarado este, porém, não apenas como expressão estética delimitada por periodizações tradicionais da História da Arte, mas, sobretudo, como visão de mundo entranhada no nosso modo de ser, de parecer, de criar e de agir."

23 FURTADO, Celso. "Quem somos? Sete teses sobre a cultura brasileira". Rio de Janeiro: Revista do Brasil, ano I, n.2/84.

24 RISÉRIO, Antonio. "A arquitetura e o artesanato popular". In Avant-Garde na Bahia, op.cit., p. 116.

25 Ver. BONSIEPPE, Gui. Diseño industrial. Artefacto y projecto. Madrid, Alberto Corazon, 1975.

26 Carta de Celso Furtado. 5 de abril de 1964. Arquivo ILBPMB. $2 \mathrm{fl}$ 
das "formas cheias de uma eletricidade vital" à produção industrial. ${ }^{27}$

Nas duas primeiras cartas, entre março e abril de $1964,{ }^{28}$ pouco antes ocupação do MAMB pelos militares, o que estava em pauta era a oposição de Lina frente ao projeto de uma exposição a cargo do Itamaraty na Europa sobre arte popular que, ao invés de problematizar as manifestações locais no bojo da civilização ocidental, a tornaria mero objeto de consumo. Na apresentação "Contribuição da cultura popular à arquitetura", Lina diria: "A cultura popular no Ocidente é vulgaridade. Ela é o produto mesmo da alienação. É o folklore da rádio e televisão, cuja continuidade as classes dirigentes estão interessadas em manter. Esta cultura falsificada tem um valor econômico-turístico considerável, mas é um valor de alienação". ${ }^{29}$

Lina questiona a interpretação de Furtado a despeito de Bahia no Ibirapuera, centrada na ideia de "consolação através da arte em lugar do planejamento econômico e da solução técnica", relembrando sua disposição em debater o problema do artesanato no Brasil, inclusive tentando uma articulação direta com ele, a quem pretendia "pedir o enquadramento técnico [do] trabalho na realidade dum planejamento, para 'historicizar' num presente econômico uma realidade válida até hoje somente no plano abstrato e poético" ${ }^{30}$ inclusive em carta para própria Sudene, endereçada a Milton Santos, então presidente da Fundação Comissão de Planejamento Econômico. ${ }^{3}$

Além do apoio direto solicitado ao governador Lomanto Júnior, ciente da necessidade de enquadramento de seu trabalho na esfera das políticas públicas, sob o risco de suas iniciativas figurarem apenas uma "programação bonita". ${ }^{32}$

Na esteira da criação da SUDENE e, na sequência, em 1962, da ARTENE Artesanato do Nordeste S.A, estariam os interesses políticos forjados pela aliança entre burguesia industrial do Centro-Sul do país e as elites do Nordeste, que temiam a desintegração do país frente à pressão das forças populares organizadas. Lina apontaria a Celso Furtado o risco contido em seu plano de desenvolvimento pautado na "tese da cultura desligada da economia". ${ }^{3 .}$ Na revisão crítica que Lina faria anos mais tarde, relataria que a Artene "não era uma iniciativa romântica, mas era um frio plano de financiamento sem preocupações estéticas. Um plano intermediário que desapareceria com o desenvolvimento e a elevação das rendas. Na 'base' estava o levantamento das condições sócio-econômicas do povo nordestino rural e semi-rural dedicado ao 'artesanato', isto é, rendeiras, ceramistas, funileiros, marceneiros, tecelões, etc, [e] desaparecido o corpo de sociólogos, antropólogos e economistas que se dedicavam àquela ação e pesquisa, a Artene subsistiu no Recife como lojinha de lembranças para turistas". ${ }^{34}$ Já Celso Furtado, escreveria à Lina que, em 1967, que "identificar as artes de uma comunidade pode ser a forma mais segura e menos custosa de dar início ao desenvolvimento da base material dessa comunidade. Mas existe o risco que nos detenhamos na fase de identificação e terminamos como a literatura nordestina que deu volta em torno dos "castelos" servindo de tranquilizante para os que não têm sono na hora da sesta." ${ }^{35}$

27 Catálogo Civilização Nordeste, 1963. Arquivo ILBPMB.

28 As cartas consultadas no Arquivo ILBPMB referem-se às datas aqui descritas. De Lina Bo Bardi para Celso Furtado em: 05/03/1964, 18/01/67 e 22/04/87. As respostas de Celso Furtado para Lina Bo Bardi viriam em 05/04/64 e outra datada apenas no ano de 1967, reproduzida em SUZUKI, 1994, op. cit., p.63.

29 Lina Bo Bardi, "Contribuição da cultura popular à arquitetura", Arquivo ILBPMB

30 Id., Rascunho de carta para Celso Furtado. 5 de março de 1964. Arquivo ILBPMB. $2 \mathrm{fl}$.

31 Rascunho de carta enviada a Milton Santos em 06/06/1963. Arquivo MAMB. A resposta viria em julho de mesmo ano, em carta assinada por Augusto Jose da Silva Silvany, diretor da SUDENE na Bahia, convidando Lina a visitar o escritório da agência governamental.

32 Rascunho de carta para o governador do Estado da Bahia, Antônio Lomanto Júnior. 1 de maio de 1963. Arquivo MAMB.

33 Lina Bo Bardi. Rascunho de carta para Celso Furtado. 5 de março de 1964. Arquivo ILBPMB. 2 fl.

34 Id., Tempos de Grossura, op. cit., p.63.

35 Celso Furtado, carta reproduzida em Tempos de Grossura, op. cit., p.63. 


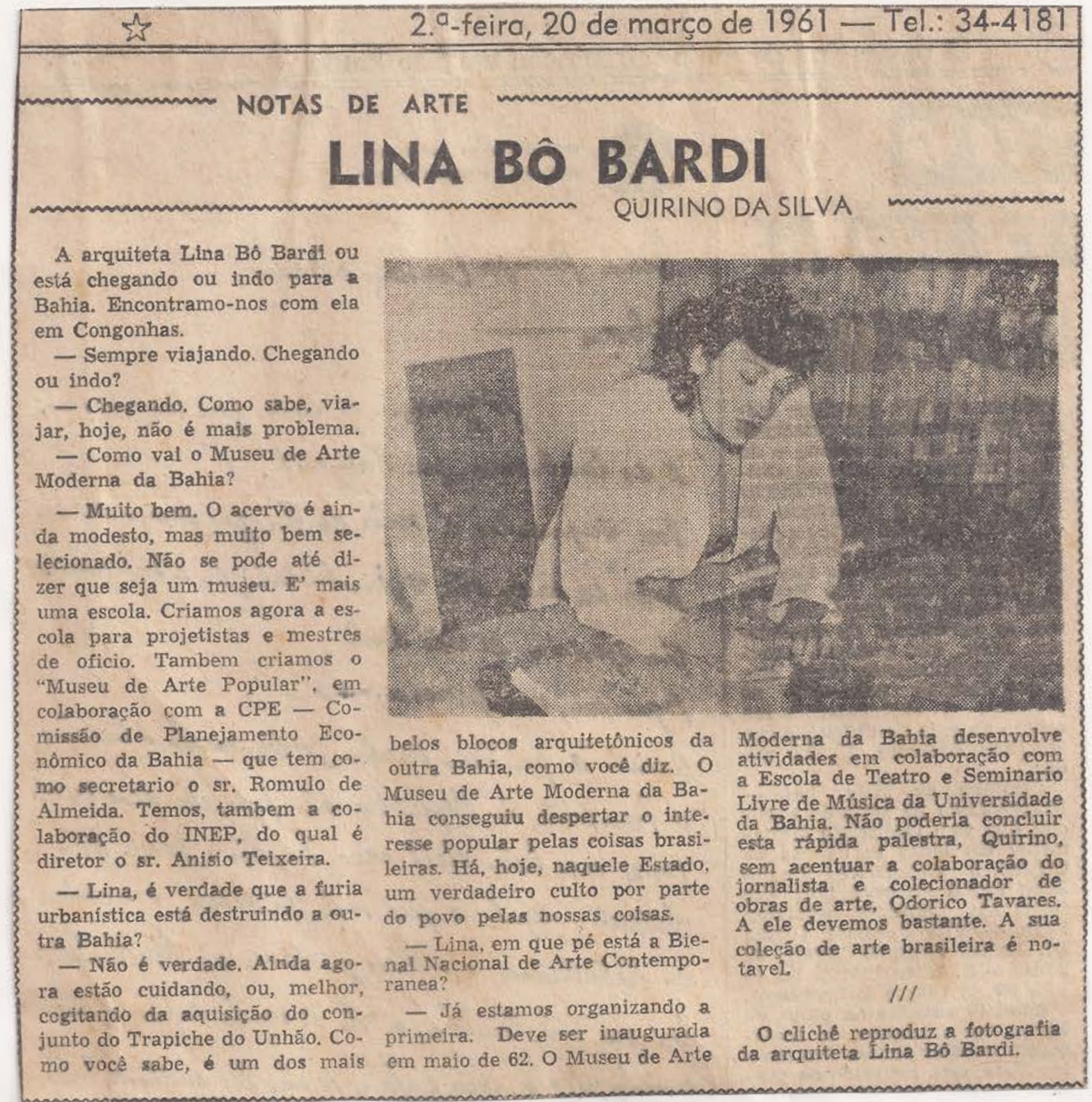

IMG 130. 


\section{Salvador 6 do junho de 1963.}

\section{PROFESSOR}

\section{MILTON SANTOS}

FUNDAÇ̃̃O COMISST̃O DE PLANEJ AMMTOO ECONOMICO

BDIEICIO BIG - NESTA

\section{Senhor Presidente,}

E propósito do Museu de Arte Roderna da Be levar a efeit to ${ }_{2}$ no próximo mês de sețembro, uma grande exposição de ARTE POPULAR NORDEST

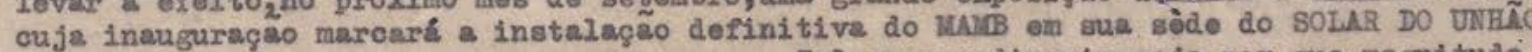

Tal empreondimonto, seja por sua magnitude $\therefore$ ja pels grande área geográfica que abrange, eatá além dos recursos de que pode no momen dispôr o nossos lluseu. Dianto de tais ofrcunstânciss, é com o maior empenho que solicito d.e V.Sa, ume recomendaçäo à Superintendência de Desenvolvimento do Nordeste - Sudene; de que possam ser postos om colaboração conosco os recursos de que a mesms possa diepô para o objetivo que temos em mente.

rá so exposto, somos

Certos do bom soolhimento que V.Ss.dilepen

muito cordialmente

IMG 131. 
Jenlar foremablor,

- Conjunto do Uhiños éapenas una "restouror cāo", mesmo se de griande felera. Agora épreciso jer realisado o flamo ole Artesanato Popular, para qu tudo não fique apenas numa porogra

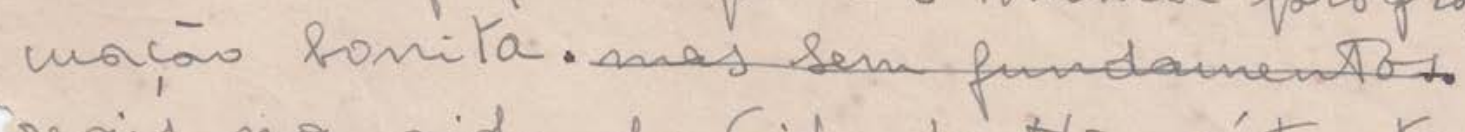
peois na vida da Cidade. Hão é tau to quertas de verba eficuirta dima ini ciativa que tenha o apôio "moral" e efetivo olo Gôverno do Estasto. Ma base do interesse denonstroudo pelo trabalho já realisodo, queria ser rece. biola por X. Exa. pour expor nosso plano técnico. Acabo de voltar blo ful - peco para nichir nosso problema, não "nos da "arte" requiutasla, ma entre os moris urgentes, sendo o plano sto Unhĩo nōo ole "arte-lazer", mas ole trabalho popular. Daola a exiguidable olo tempo escrevo pessoalmente a V. Exa. olietamente no Palácio bla Aclamação, (heroque pero pestindo permissāo para manblar saber besuce posteriarmente quoubo V. Exció poblerá noarcar-ure uma entrevista. Sellabor 1 Respeitos squente

Campo Grande, Salvador, Bahia, Brasil 51963 Lini-Bark.

IMG 132.

Carta ao governador,

01/05/1953. Arquivo MAMB. 


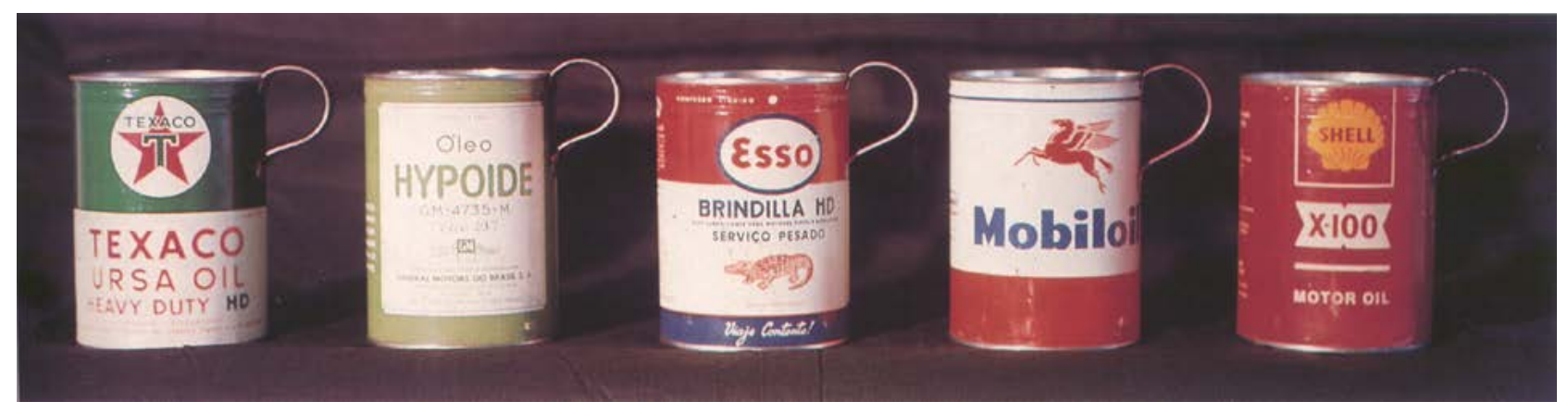

IMG 133. 


\section{Projeto Político Pedagógico}

A restauração crítica do Solar do Unhão se daria no início da década de 1960 , sobre um complexo que sintetizava nosso passado produtivo, entre Casa-Grande e a Senzala construídas no século XVII, uma capela do século XVIII e uma série de construções adicionadas entre os séculos XIX e XX.

Em "Pro-memória para uma ação na Bahia", Lina apontaria a complexidade em termos de fabricação do Solar, como um exemplo de "arqueologia industrial" no Brasil. ${ }^{36}$ Das atividades fabris que o complexo abrigou ao longo do tempo: uma fábrica de descascar arroz, no final do XVII, tabaco, entre XIX e começo do XX quando, após o fechamento, passou por uma progressiva deterioração com produções e usos diversos: depósito de inflamáveis e inseticidas, abrigo relacionado ao porto, produção de móveis, cacau, colchões e café. $O$ Instituto Nacional do Patrimônio Histórico e Artístico (IPHAN) interviria em 1943, evitando sua ruína. Mas apenas em 1960, o governo do Estado da Bahia iniciaria o processo de recuperação, a partir do projeto de Diógenes Rebouças para a Avenida do Contorno que, ao ligar as cidades Alta e Baixa, preservaria o complexo do Unhão. ${ }^{37}$

36 Lina Bo Bardi "Pro-memória para uma ação na Bahia", Arquivo ILBPMB.

37 Fruto da natureza defensiva de Salvador, sua topografia cravada na "Cidade Alta" da Baía de Todos os Santos, concentrava a vida cívica, administrativa e religiosa. A "Cidade Baixa", boêmia, matéria dos artistas, carregava as atividades relacionadas ao porto. 


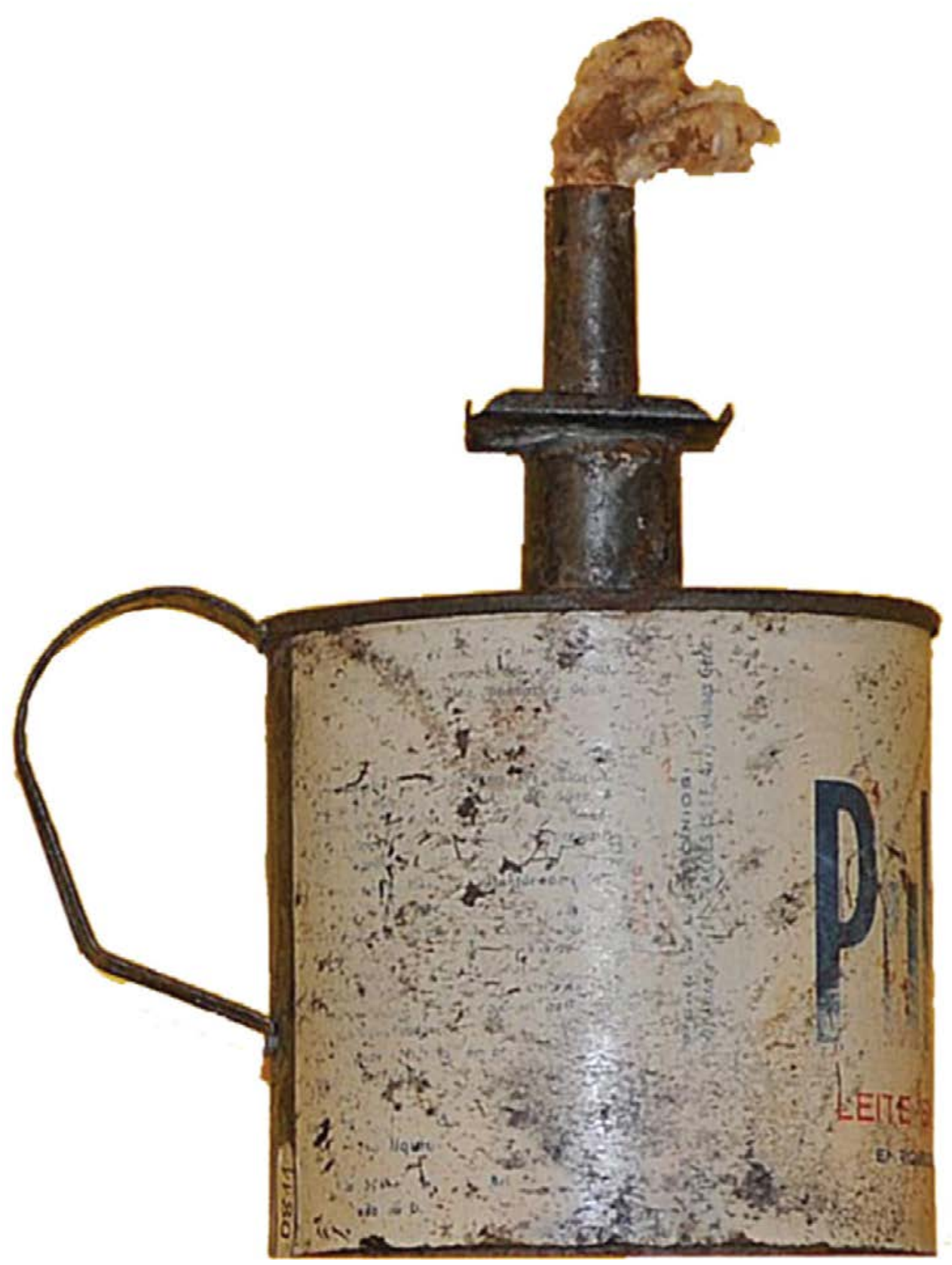

IMG 134.

Lamparina feita

com lata de leite.

Arquivo ILBPMB. 
Lina esteve no Unhão pela primeira vez em 1958, quando quatorze empresas ocupavam seus espaços de forma precária. Acompanhada de Martim Gonçalves e Sante Scaldaferri, idealizaram, num primeiro momento, ocupar o complexo com um teatro experimental vinculado à ETUB. ${ }^{38}$ Para obter fundos, entrariam em contato com Ciccillo Matarazzo Sobrinho e o reitor Edgar Santos, mudando a direção dos planos com a possibilidade da ETUB ocupar o Teatro Santo Antônio, mais próximo da UFBA.

A instalação provisória do MAMB no TCA, impulsionou a ocupação e restauração do Solar, no horizonte de duas instituições complementares. Seu restauro, financiado pelo Estado, a partir das verbas provenientes do projeto para a Avenida do Contorno, ${ }^{39}$ ficaria a cargo de Lina e, oito meses após o início das obras, em março de 1963, estariam "praticamente concluídas". ${ }^{40}$

Dialogando com os parâmetros informados pelo método de restauração crítica que apresentava outros caminhos para além dos procedimentos aplicados às restaurações estilística ou filológica, ${ }^{41}$ a obra a ser restaurada era vista em suas dimensões histórica e artística, no entendimento de uma "unidade social potencial", de acordo com o expoente do método crítico Cesare Brandi. ${ }^{22}$ Para Lina, "O conjunto do Unhão é uma antecipação dos princípios de restauração fixados posteriormente em campo internacional pela

38 Juliano Aparecido Pereira, "Entrevista a Sante Scaldaferri", em Lina Bo Bardi, Bahia 1958-1964, op. cit., p. 274.

39 Juliano Aparecido Pereira, "Entrevista a Sante Scaldaferri", em Lina Bo Bardi, Bahia 1958-1964, op. cit., pp. 274-275

40 Lina Bo Bardi, "Cinco anos entre os brancos", Mirante das Artes, Etc. 6, op. cit.

41 Métodos utilizados desde o século XIX, o primeiro, estilístico ou de recomposição, seria identificado nas obras de Eugène Viollet-le-Duc e pautava-se na ideia de estado original, cuja concepção estaria atrelada à interpretação do executor. Já o segundo, filológico, conhecido por "restauração científica", pautava-se pela integridade histórica da obra, distinguindo a matéria original das ações sobrepostas ao longo do tempo. Teria como expoente, o professor de Lina na Escola de Arquitetura de Roma, Gustavo Giovannoni. Ver BARDI, Lina Bo. Contribuição propedêutica ao Ensino da Arquitetura. São Paulo: op. cit., p.51.

42 Cesare Brandi, "Il fundamento teorico del restauro", II Restauro, teoria e pratica 19391986, Roma: Editori Riuniti, 1994, p. 17.

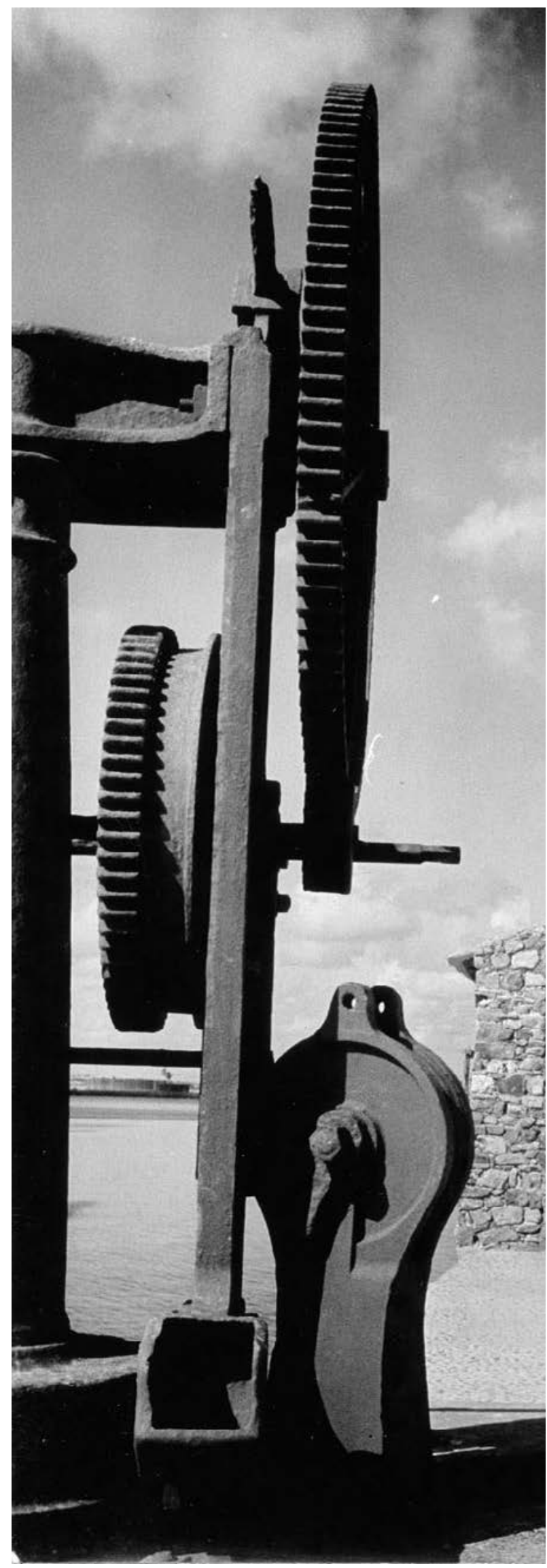




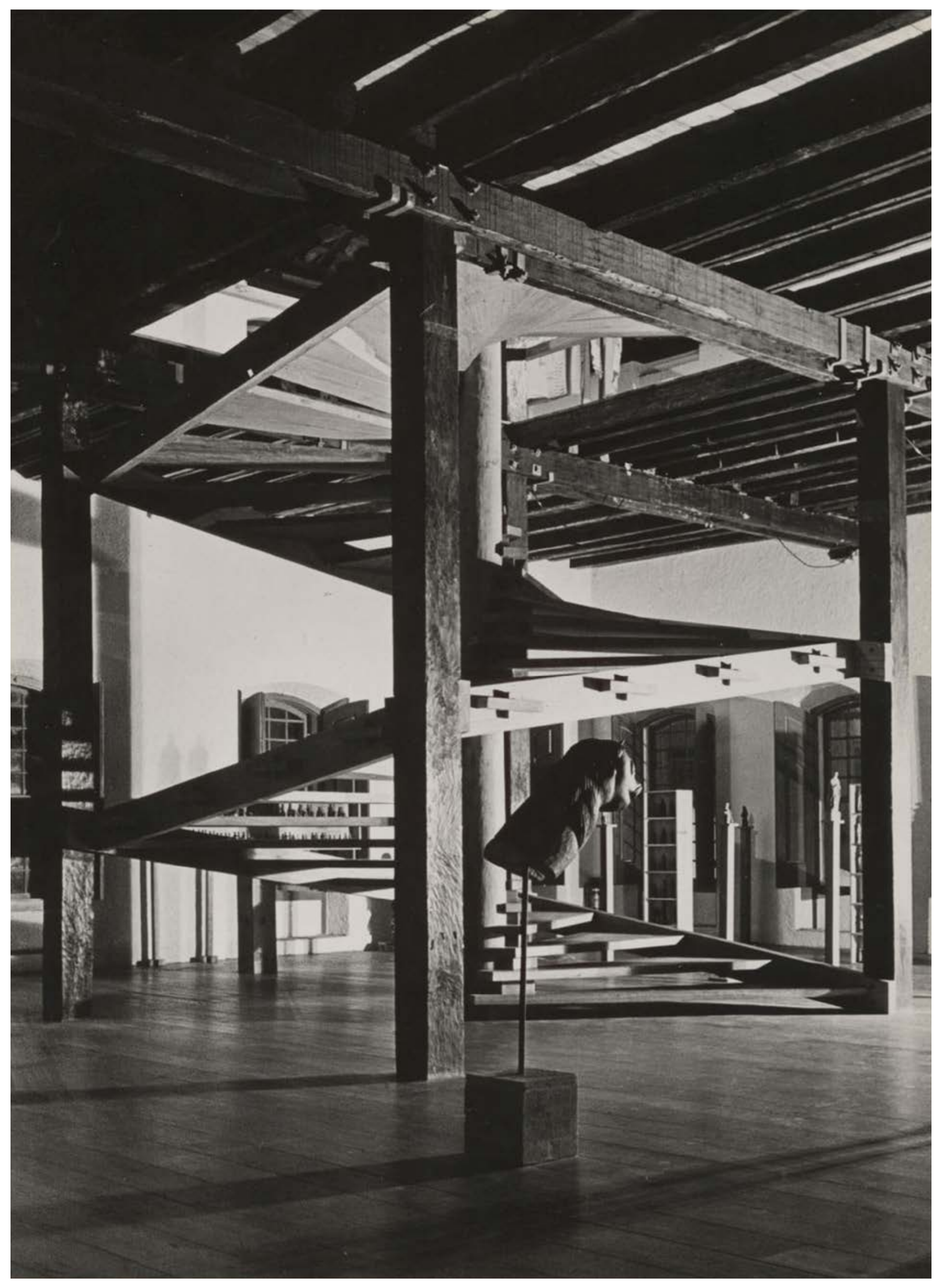




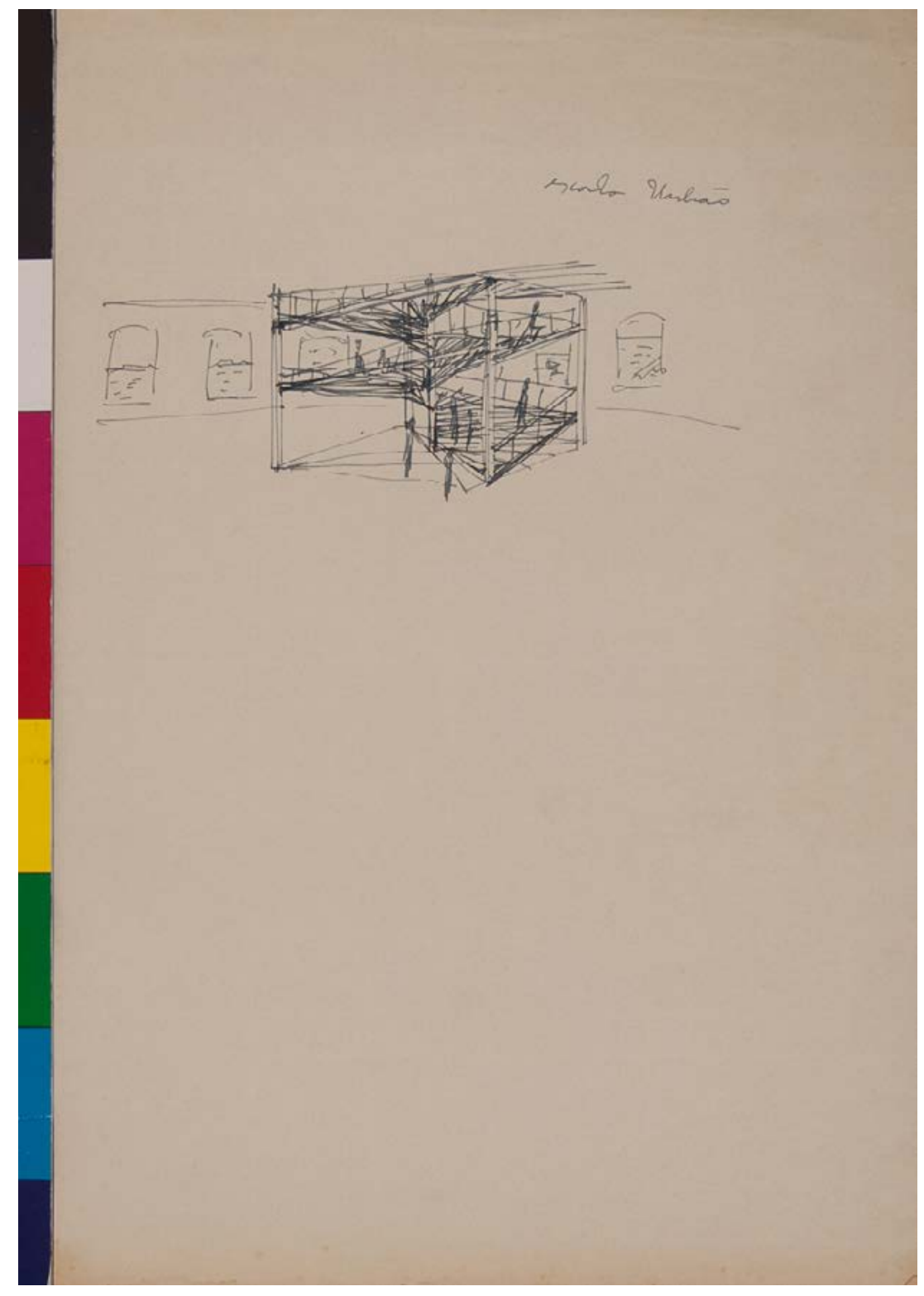

Carta de Veneza (1964-65)", ${ }^{43}$ entendendo suas ações como método e não como fim, como já apontado em Contribuição Propedêutica:

Nosso pensamento subentende a história, cuja viva presença, em sua síntese e em seu valor normativo e admoestador está implícita em nossas ações, precisamente porque nós somos o resultado dessa mesma história.44 [BARDI, 1957:16]
Da capela, Lina eliminaria as adições que descaracterizavam os valores histórico e artístico originais pautados no barroco. Diferente critério adotado para manutenção do quartel, cujo valor estaria no testemunho do "trabalho humano". ${ }^{45}$ Já as pequenas construções que avolumavam o conjunto seriam eliminadas, abrindo espaço para um terreiro junto à baía de todos os santos.

$O$ caráter produtivo que atravessou a solar era recolocado no tempo e na vida

43 Lina Bo Bardi, "Pró-memória para uma ação na Bahia". Arquivo ILBPMB

44 Id., Contribuição propedêutica ao Ensino da Arquitetura. São Paulo: op. cit., p.16.

45 Id., "Museu de Arte Popular da Bahia de Todos os Santos", incluído em Avant-garde na Bahia , op. cit. , 254.

IMG 137.

Escada do Unhão. Arquivo ILBPMB. 


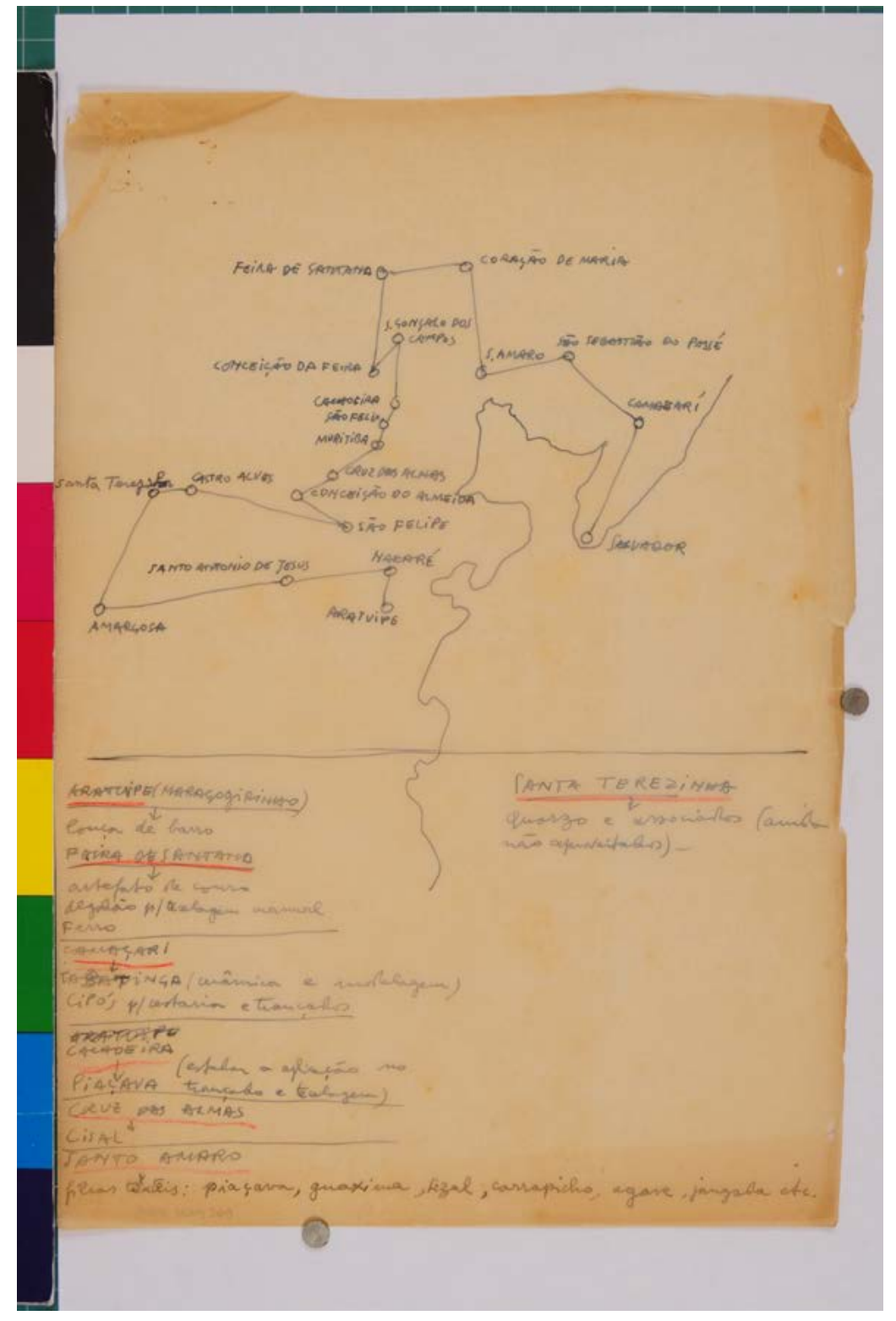

IMG 138.

Levantamento CETA.

Arquivo ILBPMB. 
moderna, seja pela manutenção dos elementos relacionados ao trabalho, como as estruturas de transporte de materiais: o guindaste, os elevadores, os trilhos Decauville, respeitando "todos os aspectos dramáticos do meio", ${ }^{46}$ seja por suas novas portas e janelas vermelhas, uma licença poética - e política, "longe de qualquer linguagem estilística", ${ }^{47}$ sinalizando a cor dos bairros populares de Salvador. Por fim, a escada de madeira, com seus encaixes de carro-de-boi, de fatura artesanal, sintetizava todo o programa-estético pedagógico do Unhão.

Se o conceito de arte popular carregava o significado político intrínseco à revisão crítica das formas de produção material da sociedade brasileira, o Museu de Arte Popular do Unhão - MAPU - seria, então, sua forma institucionalizada. Nesse duplo movimento de documentar e pensar alternativas para que desse sistema pré-artesanal surgisse um caminho possível para um desenho industrial, o MAPU enfrentava os termos de sua realidade social.

Pautado numa visão crítica sobre o artesanato, o programa aglutinado ao novo museu divergia da agência governamental SUDENE, no que se refere às "injeções oficiais" que direcionavam recursos ao setor com o objetivo de impulsionar a economia do país. ${ }^{48}$ Para Lina, tal medida não garantia a transição do artesanato local para a indústria, uma vez que as bases produtivas precisavam - necessariamente - ser repensadas. Era necessário, portanto, um projeto pedagógico, que abrigasse as atividades relacionadas à pesquisa, no enfrentamento da alienação do processo do fazer e das condições que se acumulavam na contingência da ideia de pré-artesanato.

Ao "Centro de Estudo e Trabalho Artesanal" - CETA - Lina se dedicaria ao inventário das condições do fazer, de matriz "pré-artesanal", num levantamento cujo objetivo seria identificar o potencial econômico da produção nordestina, em três fases, desdobradas num total de trinta meses (0-6, 6-18,18-30), a partir do estabelecimento de três núcleos: Salvador, Recôncavo baiano e interior do estado da Bahia. ${ }^{9}$

O programa visa o artesanato precisamente no seu conteúdo estético-cultural, sedimentado em conhecimento da matéria, em forma, em função, em eficiência e em adaptabilidade às condições do meio, no espaço e no tempo, com valores universais. Salvando esses valores, ao recolhê-los, pesquisá-los e dignifica-los, inclusive no mercado, e transferindo-os a gerações industriais em formação, o Museu de Arte Popular e o Centro de Estudo e Trabalho Artesanal serão fator de alta importância no processo de desenvolvimento sócio-econômico, atuando pela ação direta da inteligência e da cultura sobre o povo e sobre sua produção industrial, usando valores universais esse mesmo povo depurou através de séculos. ${ }^{50}$

Em carta já mencionada ao governador Lomanto Júnior, Lina ressalta a importância de apresentar o plano "técnico" para o artesanato popular, levantando o problema não "da arte requintada, mas entre os mais urgentes, sendo o plano do Unhão não de 'arte-lazer', mas de trabalho popular" ${ }^{51} \mathrm{Na}$ reivindicação desse apoio, estava o interesse de viabilizar seu projeto, face as polêmicas já anunciadas por parte da elite cultural 'artístico-intelectual", mais próxima do "velho sentido nacional, político e retórico". ${ }^{52}$ Buscaria, ainda, o apoio da Secretaria para Assuntos de Desenvolvimento Econômico do Governo da Bahia, via Rômulo de Almeida, secretário da comissão de planejamento econômico, cuja assessoria foi favorável à transformação do Solar do Unhão em Universidade popular; da colaboração da própria SUDENE que atuou juridicamente na constituição do MAPU, junto à Fundação do MAMB e ao Governo do Estado.

46 Lina Bo Bardi, "Solar do Unhão", 1963. Arquivo ILBPMB.

47 "Restauração crítica como deve ser hoje", 1963. Arquivo SPHAN, citado em Silvana Barbosa Rubino,

"Gramsci no Museu, ou a arte popular no Solar do Unhão, Salvador 1963-64", op. cit.

48 Lina Bo Bardi, "Arte Industrial", op. cit.

49 Lina Bo Bardi, "Conceituação do Programa". Arquivo ILBPMB, reproduzido em Suzuki, tese, p. 345.

50 Ibidem.

51 Id., carta manuscrita ao governador da Bahia, Lomanto Júnior, escrita em Salvador, 01/05/1963. Arquivo MAMB.

52 Id., "Teoria e filosofia da arquitetura". In: RUBINO,S.;GRINOVER,M. (orgs.). Lina por

escrito. Textos escolhidos de Lina Bo Bardi. São Paulo: op. cit., p.85. 
Evidente que haveria um conflito de interesses entre os órgãos públicos mencionados que pouco compactuariam com o projeto pedagógico delineado para o referido museu, em direção a um desenvolvimento autônomo da cultura popular. Mais próximos de seus propósitos estariam o diretor do Museu de Arte da Universidade Federal do Ceará (MAUC), Lívio Xavier e o chefe da Casa Civil de Recife, Francisco Brennand, que formariam o triângulo do Nordeste, ${ }^{53}$ - uma frente de ação sobre a cultura popular, cujos desdobramentos se daria na transformação da antiga Casa de Detenção do Recife em Casa da Cultura, em 1964.

As políticas oficiais do artesanato viam nos investimentos do setor uma forma de absorver a mão-de-obra ociosa dos períodos de baixa produção no campo, que vivia da sazonalidade do trabalho. Com o objetivo de fortalecer a economia local pela formação de um campo que oferecesse demanda nesses hiatos de improdutividade, políticas de apoio financeiro e de formação eram destinados aos artesãos. Essa formação, muito distante do projeto pedagógico de Lina, estaria mais próximo de uma capacitação para um setor industrial desejado, do que para o desenvolvimento de uma cultura autóctone efetiva, ainda que idealizada no bojo das políticas de assistência. A distância das ideias de Lina, para quem projeto e execução deveria ser repensado em novas relações produtivas, pode ser vista de imediato na introdução de Rômulo de Almeida - "Exposição sobre o Problema do Artesanato na Bahia" - para o livro Artesanato e Arte Popular: ${ }^{54}$

Um programa de amparo ao artesanato e à indústria-doméstica tem a enfrentar grandes dificuldades técnicas quanto aos limites econômicos, modalidades de fomento e métodos de assistência a utilizar. (...) face ao interesse social relevante (...) sobretudo para as mulheres e o lar, e ao interesse econômico considerável,

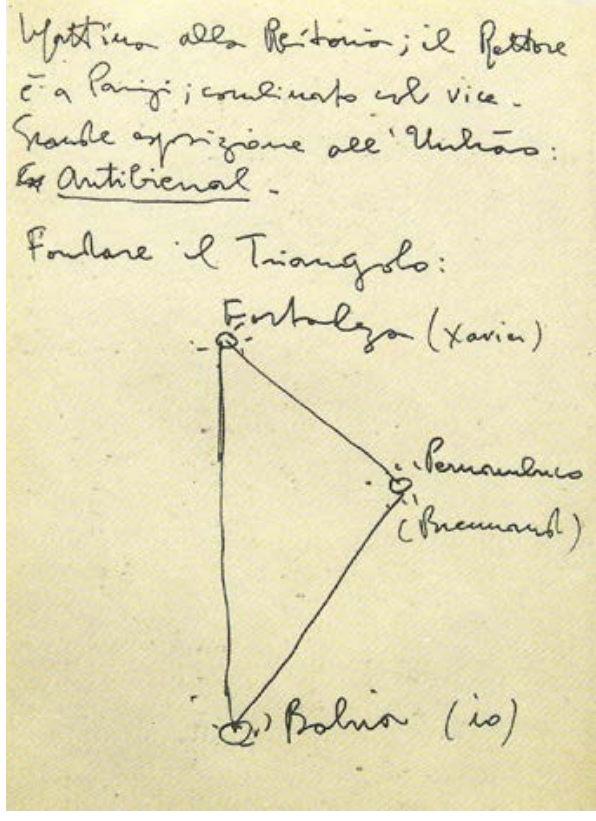

IMG. 139.

Triângulo do Nordeste. [FERRAZ, 1993:152]

onde as oportunidades de emprego em indústrias fabris são limitadas e o capital é escasso. As indústrias-artesanais e domésticas permitem mais empregos por unidade de capital, fomentam a poupança e o pequeno e disperso investimento popular além de completarem a economia agrícola e de constituírem uma preparação magnífica de mão-de-obra qualificada e à capacidade empresária. Apresentam ainda apreciável fertilidade cultural.

O projeto do MAPU, por sua vez, pautava-se do ponto de vista econômico-social, “suscitar o 'interesse' em torno da produção artesanal, propiciando, consequentemente, a DEMANDA econômica, implicando em desenvolvimento do trabalho em zonas inteiramente artesanais". ${ }^{55}$ Ao progresso econômico estaria contido, portanto, um desenvolvimento correlato na produção artesanal, em direção à indústria.

$O$ verdadeiro e único centro que possa e deva surgir uma orientação no tocante à

53 Desenho reproduzido em FERRAZ, M. (org,). Lina Bo Bardi, op. cit. 152.

54 Rômulo de Almeida destacaria a importância dos trabalhos na área, associando a Comissão de Planejamento Econômico ao Serviço Nacional de Aprendizagem Industrial (SENAl) e, especialmente, os incentivos do Governo do Estado ao trabalho do Professor Carlos José da Costa Pereira, autor de diversos estudos e pesquisas acerca do artesanato e da formação histórica da mão-de-obra no Brasil. Ver Rômulo Almeida "Exposição sôbre o Problema do Artesanato na Bahia", em Artesanato e Arte Popular, de Carlos José da Costa Pereira (Bahía: Instituto de Economia e Finanças da Bahia, Livraria Progresso, 1957$), 171$.

55 "Projeto da Escola de Artesanato. Dados informativos sobre o conjunto arquitetônico do

Solar do Unhão e as atividades atuais do MAMB e MAP unhão ", op. cit. 
A respeito do artezando popular do nordeste brasileiro

- de sua recriação por G. de C., escreve Wilson Rocha:

" opinião generalisada de que há uma tradição segundo a qual existe no Brasil,e particularmente na Bahia e no Nordeste, um rico passado de artezanato popular de ax te domb́stica. A engenhosidade, a sensibilidade inventiva - 0 gôsto decotativo do nosso povo são evidente em todos os seus movimentos encontram expressão numa rica variedade de materiais. Grande parte dessas tradições, mantêm-se ainda e al estão os belos padrões de tecelagem das rêdea do Ceará, dos chales ou "pano da Costa"da baiana, das rendas ianduti e de barafunda e dos bordados de ponto de cruz elaborados com amor pelas mãos generosas das moças de côr da Bahia.

Numa faixa que se estende da Bahia a Ceark, o artezana to, das rêdes, rendas o bordados do nordeste brasileiro é um "métier" que remonta a cerca do aéculo meio. Sua origem tem várias versões; segundo uma das quais seria Êle um legado dos Indios Tupinambás e Tupininquins, anti gos habitantes do litoral brasileiro daquela região.

Porém o fato \& que, êste "métier", modificado e deturpado, e, já agora, influenciado por processos europeus, vem passando de mãe para filha como herança profissional e tradicional. Todavia, a nossa arte popular tem ratrin Izes profundas e complexas, e, em particular, nas suas primitivas técnicas de tecelagem e bordado, ela evidencia, em certos detalhes, uma intima relação com a antiga técnica da chamada tapeçarias de Canevas,processo ệ te de origem medieval, que precedeu a tapeçaria de teares.

Partindo dos próprios fatores do nosso complexo cultural e com o objetivo de aproveitamento de um potencial humano perfeitamente adaptado a tais processos de manufaturas, Genaro de Carvalho levou a efeito uma experiênexa cia até então inédita no Brasil e que se destina a realização e confecção de peças de tapeçarias mural pelo an tigo processo de Canevas, utilizando para isso a própria experiência do artezanato popular e empregando, om grupos selecionados, tecelãs e bordadeiras portadoras de tradicionais ofloios das moças do povo da Bahia." 



\section{Weimar 1918 está longe na História}

Arquitetura é simplesmente a Escola, com tudo o que ela implica no sentido da livre pesquisa da discussão e intercâmbio intelectual, fontes estas extremamente importantes da atividade dos atuais e dos futuros arquitetos, em fecunda oposição a todas as atitudes dogmáticas e constrangedoras das faculdades criadoras do homem. ${ }^{56}$

No catálogo "Brennand Cerâmica", de 1961, Lina faria uma síntese, a partir da trajetória do artista, das principais questões que norteavam suas pesquisas acerca de arte popular e desenho industrial, no bojo de uma revisão crítica do termo artesanal no Brasil.

O Brasil está conduzindo hoje, a batalha da cultura. Nos próximos dez, talvez cinco anos, o país terá traçado os seus esquemas culturais, estará fixado numa linha definitiva: ser um país de cultura autônoma, construída sobre raízes próprias, ou ser um país inautêntico, com uma pseudo cultura de esquemas importados e ineficientes. Um ersatz da cultura de outros países. Um país apto a tomar parte ativa no concerto universal das culturas, ou um país saudoso de outros meios, mundos e climas. O Brasil, hoje, está dividido em dois: o dos que querem estar ao par, dos que olham constantemente para fora, procurando captar as últimas novidades para jogá-las, revestidas de uma apressada camada nacional,

56 Lina Bo Bardi. Contribuição propedêutica ao Ensino da Arquitetura. São Paulo: op. cit., p, p.32. 


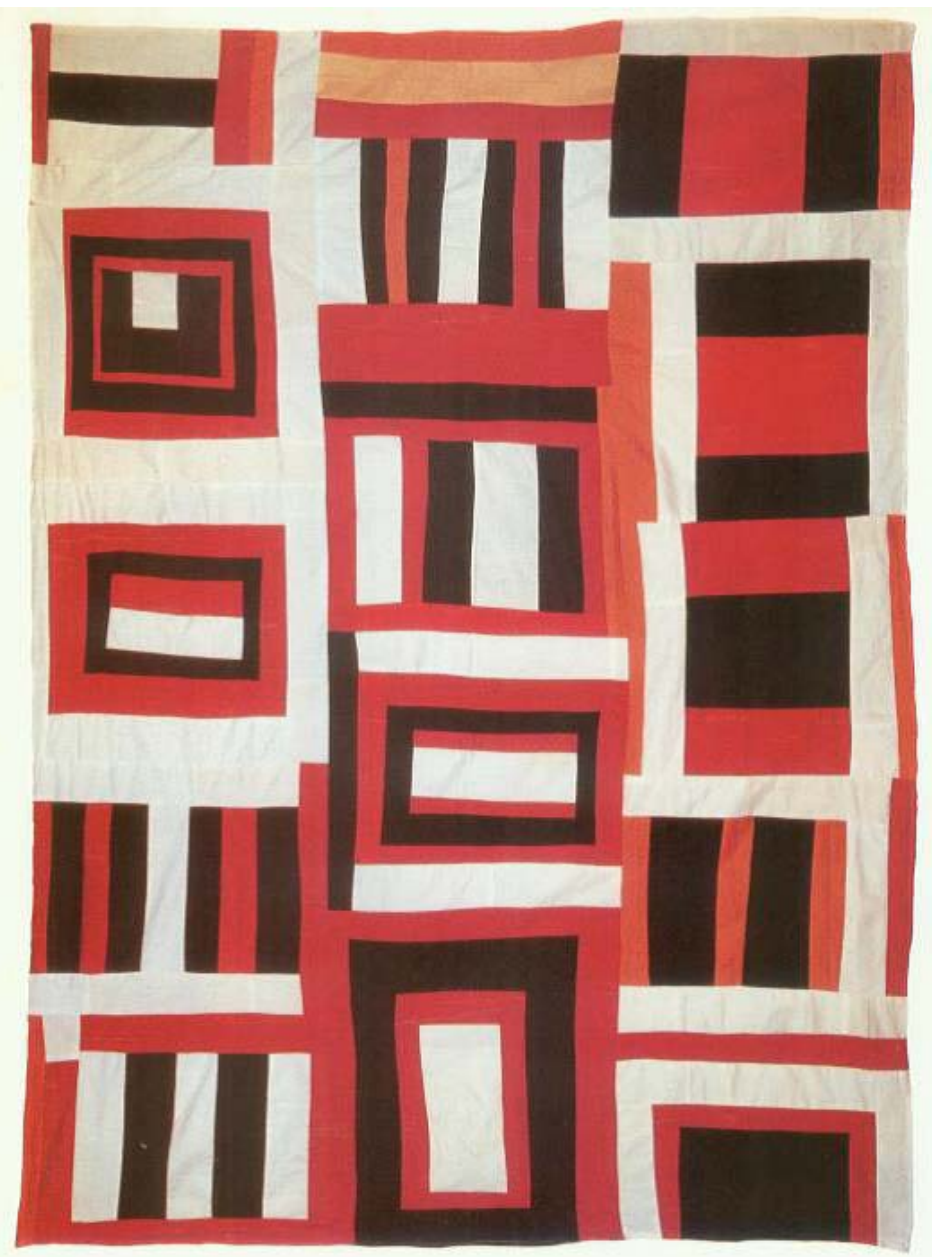

no mercado da cultura, e o dos que olham dentro de si e em volta procurando fatigadamente nas poucas heranças duma terra nova e apaixonadamente amada, as raízes duma cultura ainda informe, para construí-la com uma seriedade que não admite sorrisos. Procura fatigada, no emaranhado de heranças esnobisticamente desprezadas por uma crítica improvisada que as define drasticamente regionalismo e folklore. É uma aristocracia ligada ao mundo popular, às civilizações do litoral ou do sertão, uma inteligência camponesa e artesanal que procura na terra e na condição humana a sua expressão. A palavra artesanal provoca, em quem não tenha bem clara a textura da sociedade contemporânea e dos esquemas de desenvolvimento e produção industrial modernos, uma revolta, quando não um sentimento de diminuição que pode ser resumido na expressão: artesanato-antigo, indústria-moderno: artesanato-inferior, indústria-superior. Não existe na realidade diferença, hoje. O século XIX viu na máquina uma inimiga. $O$ entusiasmo romântico-maquinístico do começo do século $X X$ viu no artesanato uma forma superada. $\mathrm{Na}$ máquina que produz o objeto padrão, pensado e desenhado num sentido de artesanato-industrial, está a verdadeira síntese da arte aplicada moderna, o seu ponto final. Francisco Brennnad pertence a aristocracia do popular, ao mundo da procura. Ligado a uma grande indústria, preso a uma realidade de cada dia, não pode deixar de transmitir esta realidade à sua produção. Sua cerâmica, pratos e placas alinhados no chão e nas mesas da grande e velha casa do engenho São João, em Pernambuco, tem um sentido de austeridade medieval. Sentido estranho, quase inoportuno numa terra tão longe dessa atmosfera. De repente no verde das plantas nos animais lentos na paisagem, este estranho sentido de Idade Média se caracteriza naquilo que a Idade Média teve de marcante: a medida humana, o trabalho, a natureza perto dos homens. E a sensação de estranheza deixa lugar às simples verdades da natureza tropical e do homem nela. A cerâmica de Brennand é importante. Por esta procura de simplificação aristocrática e popular, concretizada numa técnica séria. Pratos e placas. Grandes pratos e placas ainda "Peças Únicas". A ligação de Brennand com

IMG 141.

Pano de algodão. [SUZUKI, 1994:30] 


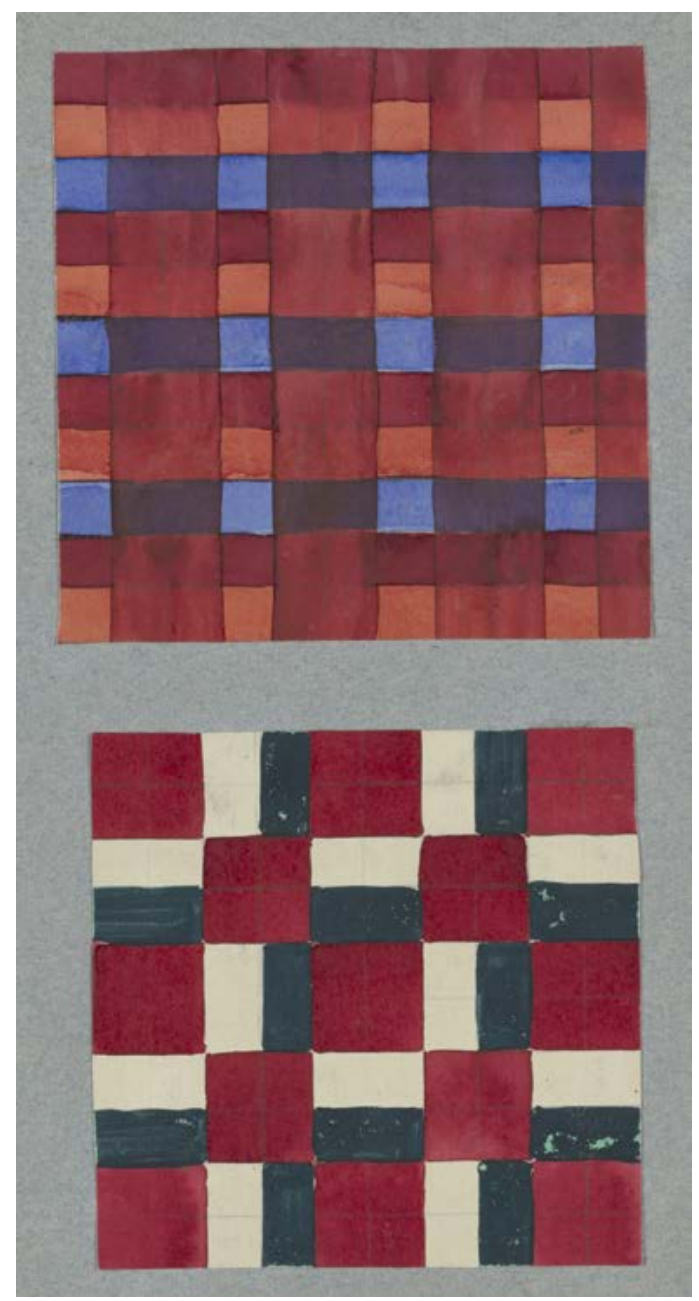

IMG 142.

Exercícios Bauhaus - Klee

[Arquivo Zemtrum Paul Klee]. a indústria não o levou ainda à procura de formas, à transferência de sua sensibilidade aristocrática e camponesa na produção do objeto que acompanha o homem na vida de cada dia, como as grandes civilizações orientais o fizeram. Mas Brennand chegará a isso; é um processo fatal. Não por acaso Brennand no catálogo d'uma sua exposição citou o grande mestre do "Werkbund", o arquiteto Henry Van de Velde criador do moderno desenho industrial. São a síntese d'uma perfeita intuição do rumo da arte moderna: 'E o espetáculo da natureza completa a lição da história'."

A proposta pedagógica do Museu de Arte Popular do Unhão se daria na integração do museu propriamente ao Centro de Estudos do Trabalho Artesanal - CETA, e à Escola de Desenho Industrial.

Em termos de produção, Lina defendia os valores da pré-fabricação como catalizador de uma industrialização progressiva, dada a precariedade do setor no Brasil. Mas, diferentemente da Bauhaus, cujo sistema já constituído do artesanato na Alemanha o levou a ser pensado como modelo pedagógico para a indústria, o Brasil impunha uma etapa preliminar a essa transposição artesanato-indústria, seja porque a ideia de modelo veiculava-se a uma utopia já revisada no contexto do pós-guerra, seja porque o sistema do mundo artesanal carregava em si a fragilidade de seus termos em solo brasileiro. Era necessário, portanto, investir em pesquisas que reunissem as condições do fazer no mundo artesanal, a ponto de formar uma cultura cujos "valores universais" responderiam a pedagogia de um sistema que poderia então servir de referência para o desenho industrial.

Um país jovem, sem bases de cultura que não as necessariamente importadas, e ineficientes por desligadas da verdadeira realidade do País, não poderá construir uma 'verdadeira' cultura. Cultura não é abstração, mas 'sistema', 'meio' para se conseguir viver no sentido pleno da palavra. ${ }^{57}$ 


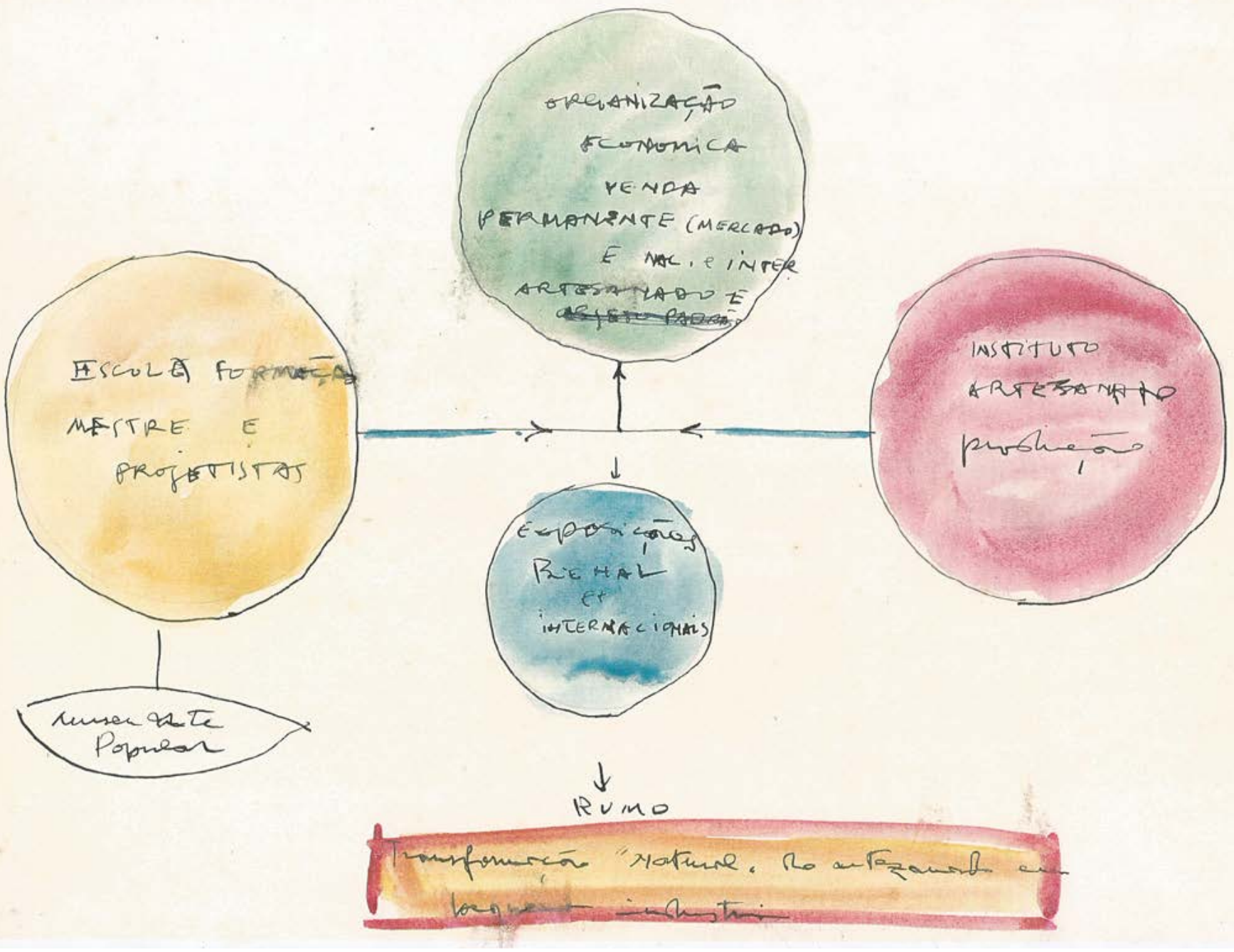

IMGS 143-144

Esquema Escola de Desenho Industrial e Artesanato. Arquivo MAMB 


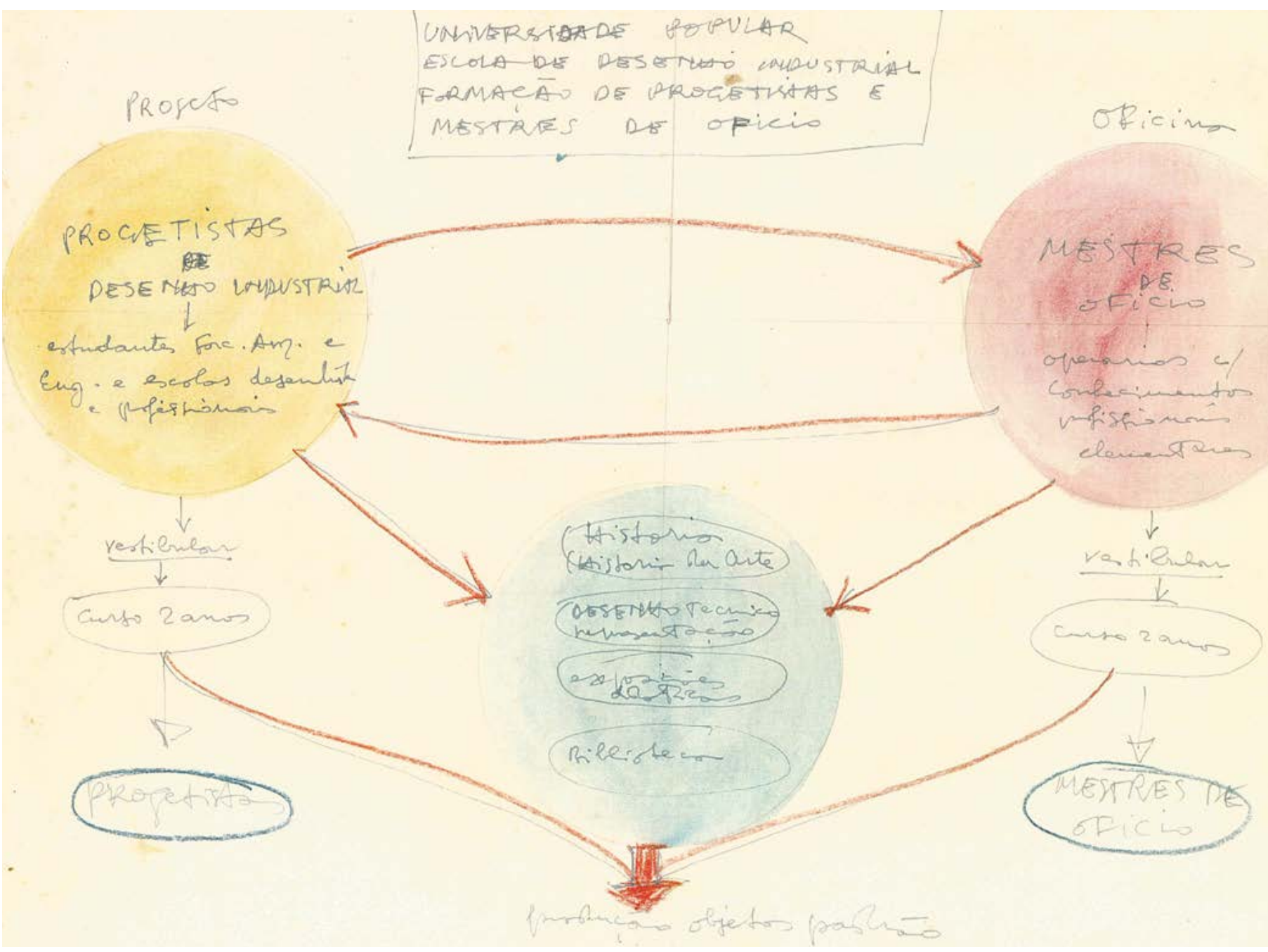

A essas referências, importante ressaltar, espelhavam-se propósitos pedagógicos, não produtivos, e sua reprodução a partir de um sistema industrial "não significa[va] preservar formas e materiais, mas avaliar as possibilidades criativas originais". ${ }^{58}$ Assim, CETA e Escola de desenho industrial operariam juntas, para "implementar, sobre uma realidade prática e uma colaboração projeto-execução efetiva, a atividade que se anuncia como significante de nossa civilização: a produção de Arte ligada à vida prática: artesanato transformado em Industrial Design". ${ }^{.9}$
O raciocínio colocado por Lina em que "uma escola tipo Bauhaus ou Ulm metafísico-experimental seria inútil a um país jovem, com uma civilização de fatores fortemente primitivos e diretamente ligados a terra", ${ }^{60}$ não a impediria de perceber a necessidade de transição de um sistema artesanal para o industrial em construção entendo as implicações disso na construção de um método pedagógico.

Evidente que a Bauhaus esgarça as relações entre a arte e técnica e é o pano de fundo sobre todas as iniciativas de institucionalização do design que ocorrem

58 Id., "Por que ou Nordeste?", em Tempos de Grossura: o design no impasse, op. cit.,p. 21.

59 Id., "Projeto da Escola de Artesanato. Dados informativos sobre o conjunto arquitetônico do Solar do Unhão e as atividades atuais do MAMB e MAP unhão ", op. cit.

60 Projeto da Escola de Artesanato. Dados informativos sobre o conjunto arquitetônico do Solar do Unhão e as atuais atividades do MAMB e MAP Unhão. Arquivo MAMB. 
IMGS 145.

Revista A, 1946.

Foto Kipnis. Acervo Grinover.

entre as décadas de 1950 e 1960. Mas, em um contexto pós-industrial, qual o papel da cultura diante do sistema produtivo capitalista?

Assim, no "biênio propedêutico" posto como currículo da Escola, cujo calendário previsto datava março de 1963 , haveria um treinamento conjunto para mestres artesãos e desenhistas industriais, potencializando as habilidades práticas dos primeiros às teóricas do segundo. Assim, do pré-artesanato era possível vislumbrar o horizonte de um industrial design que, na contramão da finesse, nos levaria à uma cultura autóctone codificada em linguagem industrial, fundada nas necessidades efetivas do país. Ao pré-artesanato, contudo, era preciso rever o duplo sentido da alienação do trabalho: da fratura entre projeto e execução mediada pela máquina à alienação presente no sistema já fraturado nas relações de trabalho no Brasil, que inerentes ao processo de fabricação de um operariado que, por definição, não era detentor de seus meios e, logo, despido da espiritualidade contida no gesto que opera o mundo da matéria.

A época de hoje é de novo ARTESANAL, as máquinas caminham para ser dominadas por poucos homens, em breve por um só homem; as condições artesanais estão quase restabelecidas, o caráter novamente 'artesanal' do objeto produzido já se está delineado. Em vez do martelo e dos instrumentos artesanais, os homens movem comandos mecânicos mas o orgulho e a consciência do próprio trabalho devem ser de novo estabelecidos. ${ }^{62}$

A partir do problema da industrialização premente colocada pelo ethos desenvolvimentista, responsável por excluir do crescimento econômico grande parcela da sociedade, Lina não só buscou o apoio da Sudene, como também do Instituto Nacional de Planejamento - INEP, dirigido então por Anísio Teixeira, ${ }^{63}$ cujo projeto das "Escolas Parque" dialogavam com os pressupostos que orientavam as práticas pedagógicas de Lina, pautadas no valor da escola enquanto instituição democrática.

É preciso não esquecer que, num país democrático, os meios de afirmação das ideias - e mesmo daquelas que reputamos as melhores - estão sempre à disposição: são a educação e o exemplo, em lugar da coação intelectual e da fiscalização; eis porque a teoria não pode prescindir da crítica, muito interessando, pelo contrário, o normal discorrer cotidiano, destituído de caráter áulico, mas tendo como seus fundamentos o bom senso e o bom gosto. ${ }^{44}$

$O$ ingresso seria feito a partir de um processo de seleção. Os dados informativos sobre as atividades da escola, informam que as atividades se dariam na colaboração entre "onze mestres e 44 discípulos previamente selecionados dentro os 3000 do Centro Educacional Carneiro Ribeiro", projeto pedagógico piloto de Anisio Teixeira. ${ }^{65}$

As oficinas seriam dividias em doze setores, empregando o conhecimento técnico de inúmeros materiais vinculados ao escopo da produção a ser identificada pelo CETA: metais ferrosos e não-ferrosos, pintura, cerâmica, fornos e estufas, vidros, pedras, madeira, tipografia, estamparia, tecidos e rendas em geral, artigos de couro e palha.

Além de história da arte, estética ou geometria descritiva, conteúdos teóricos de outras áreas estavam colocados, desde as diversas manifestação artísticas, como teatro e música, mas também medicina, biologia e sociologia fariam parte do programa desejado.

O primeiro ano da Escola denominado "propedêutico", combinaria teoria e prática, num curso preliminar. Em grupos de

61 Lina Bo Bardi. "Biênio propedêutico", acervo MAMB.

62 Lina Bo Bardi. "Artes Menores". Notas para criação duma cadeira de desenho industrial. Angulos, p.123.

63 Cf. Pereira, Juliano. A ação cultural de Lina Bo Bardi na Bahia e no Nordeste. pp.108-9

64 Lina Bo Bardi, Contribuição propedêutica ao Ensino da Arquitetura. São Paulo: op. cit., p.31.

65 Lina Bo Bardi. Projeto da Escola de Artesanato. Dados informativos sobre o conjunto arquitetônico do Solar do Unhão e as atuais atividades do MAMB e MAP Unhão. Arquivo MAMB. 


\section{Erame Vestibulars Português (ortografia e sintari) \\ Historia \\ Teste ๔ôbre 'memaria visual' e capacidade de analise e observagão. (a resma necesฐล̊ria \& Improviaação, pedir na $\left.E_{\bullet} \cdot \mathrm{U}_{\bullet} \mathrm{B}_{\bullet}\right)$.}

\section{Bî̂nio Propedeutico}

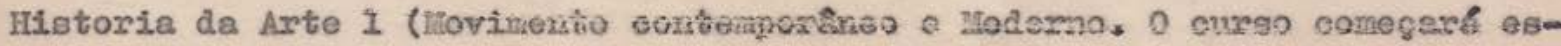
tudando o movimento das corrertes contemporâneas pera su bix no tempo. A historia cia axte ten que ser 'bistoria';

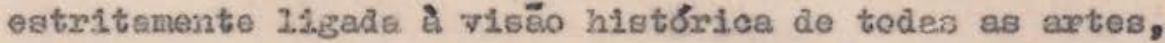
inclusive musicea, litexatura e teatro. Não como Irio elenco, mas como 'carateres dos diferentes termos o Época Serẽก oscolhicas poucas obres, e das mais significativas As aulas sexs̃o dadอs com grojeções, quase que exclusivamente. Serão acompenladas por debgtes, projeções de fıllm documentsaios, audiçōes musicais, leituras e assistênc1 es a representagão de trechos de obras teatrais.(dança, espago). Jeituras: HIstoxia da Arte de Hauser",SABBR VER de Narangoni, SOBRE A ESPIRIMUALIDADE NA ARTE de Kan diøky, EDUCAÇO ATRAVis DA ARTE de Herbert Read, (comple tax)

Historia da Axte 20 cuxso continua sublndo no tempo. Ielturas: capitulos sôbre I.eB,Alberț e Jeonardo, VIDA DE BEIVUEUTO CELLINI, TRATPATO DILIA RITTURA di Cemnino Cennini. (completar).

Bstetice.

Sumáxio da histoxia da Estetice.(as aulas serão acompanhartas de 'exercitaçōes' com referêncla à linguagen da critica de axțe, e aplicsção a esegese de trabalhos de pInture ou escultura. discuasên sôbre trabalho de P1cas so, Mst1.sae, Kieo, Kandisky, Goya, Bernini, escultuxas gofticas a romanicas (completar).

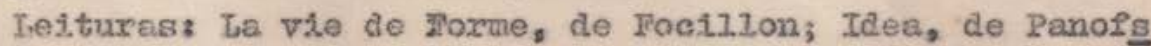
ky; Paginas de Goethe, Be1.ors, Diderot, Baudelaire, Fro mentin. Hiatoria da Axitica de Arte de Venturi(completar

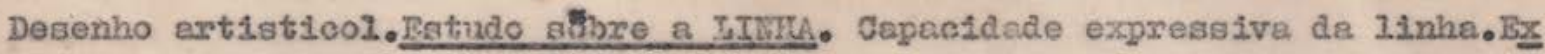
excitaçãõ; desenhos de objetos representativos 'linear-

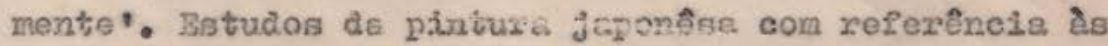
'caligrafila' orientais. Transcrição em têrmos 'caligraPloos' de formas e objetos. Leituras: Peedegigike Buch de Klee, Shio Sakanisht, The spirit of the Irush. Arthux Fope, The Langlase of Drawing and Patnting. (completar). 
Desenino artistico2. Dorma, Diagremes tridimensionais, (construção de diagre mas sరిbre obras celebres). Fstudos de formas como 'simbolo da expressão". Bxercibaçōes desenho de formas como abstraçäo expressiva. (objetos blológicos e flsicos, e meonicos), conahas, flores, pedsa de maquinas.

Modelagem 1, 2. Composigño e estudo de difarentes natexiais. Corposigões elementares nos isversos matemiais.

Arquitetura

Analitica

Estudo do 'organismo' arquitetônieo no tempo, começendo gelo contemporâned, Espixito dos 'estilos', con par ticular xeforência as axtes aplicadas. Conceitos espaciais e volumb́tixicos de exquitetura, estudos de um exomplo representativo de cada Spoca. Desenho interprotati espacial. dêstea monumentos. Je1tuxas: Ruskcin e Morris; Pevsner, Geofrey 5cots, Gledion. Movinento Bauhaus, De Stijl.

Geometrica

O programa cientffico dever: ser acompenhado pela apre Descritiva. sentação de maquetes espaciais dos difsrentes problemas, (construidas em papelão ou melhor celulóide, pelos alunos).

Perspectiva. Reconstituição prospectiva de monumentos com diferentes métodos (através de fotografia), ou de obras pitó ricas (atrevés de fotografias).Jiementos cientificos acompanhados, pelo que se refere as sombras, por maguetc i.tuminadas.

Anatomia e Estudo do corpo humano na sua 'extensão espacial'. P1losorla ArtistI Volumes, Pormas e movimentos. Relaģes do corpo humano ca. com os objetos; medidas; ingombri spaziali; estudo $x \underline{\text { g }}$ pido da estrutura óssea e miológica do corpo humano.

Bstudos brasile1- Tomagäo do homem estetico brasile120, Anfluencias ros afro-omientais e europeizas. io egtudo deveré ser feito com exemplo próticos, especisimente sôbre 'objetos'. Arquitituxa e Pintura e Bsoultura irealleira devom sor enclufdas no curgo de Historia da Arte. Ieituras: $(\ldots \ldots \ldots \ldots)$ 
vinte pessoas, entre mestres artesãos e desenhistas industriais, ao exemplo do vorkus de Gropius, cuja prática se dava, num primeiro momento, por mestres da forma e mestres artesãos. Nas oficinas pensadas para o Unhão, mestres artesãos e projetistas fariam um treinamento conjunto, no qual os primeiros aprenderiam representação gráfica, para que pudessem referenciar tecnicamente os materiais, além do conhecimento do programa estético-histórico que fundamentaria a linguagem moderna; já os segundos aprenderiam sobre os materiais e processos de execução aliado ao valor da tradição incorporada ao fazer, uma vez que "os matérias modernos e os modernos sistemas de produção tomarão depois o lugar dos meios primitivos, conservando, não as formas, mas a estrutura profunda daquelas possibilidades". ${ }^{66}$

No horizonte dessa sinergia, estaria não só a melhor qualidade do produto industrial, mas a construção de uma instituição pautada por uma revisão dos valores da sociedade, traduzidas em linguagem industrial. Assim, "o contato com a realidade artesanal, nas oficinas-piloto do Unhão, proporcionará o ambiente necessário para integrar a experiência humana do artesão e do designer industrial, permitindo-lhes participar das transformações econômico-culturais. Como laboratório, dará origem à mentalidade técnico-artística necessária para a transformação do artesanato em pequenas indústrias" ${ }^{67}$

O projeto de "Universidade Popular", pautado na relação sinérgica entre Museu,
Centro de Estudos Artesanais e Escola de Artesanato e Desenho Industrial seria implementado parcialmente. Constaria, ainda, em suas atividades, a instalação de uma feira de objetos artesanais, sob os arcos da Avenida do Contorno, com o objetivo de "apresentar ao público a produção artesanal livre de especulações intermediárias", ${ }^{68}$ que seria inaugurada na ocasião da exposição "Arte Popular da Bahia", ambas não realizadas.

Na tríade acima mencionada - museu, pesquisa e escola - residiria o objetivo de promover o progresso socioeconômico através da passagem de uma tradição artesanal, na qual estaria contida a necessária revisão de seus termos, para o desenho industrial, através do enfrentamento dos valores da arte popular e suas formas de produção, reestabelecendo na passagem proletário-artesão a satisfação moral do fazer, como possibilidade para uma cultura autóctone e moderna em sua operação coletiva de repensar os meios, as condições e as trocas no universo do trabalho.

Nesse "caminho" identificado por Lina, estaria uma política própria institucional, que desvelava sua divergência em relação à política artesanal oficial e constituía um paradoxo dentro das políticas do setor, no qual Lina estava inserida por meio do projeto do Museu de Arte Popular do Unhão.

não adiantaria fundar uma nova 'Bauhaus' no Nordeste, o próprio Gropius não corresponderia a uma realidade tão difícil, tão pobre, e Weimar 1918 está longe na História 70

66 Id., Tempos de Grossura, op. cit., 21.

67 Lina Bo Bardi "Conceituação do programa", op. cit

68 Id., "Projeto da Escola de Artesanato. Dados informativos sobre o conjunto arquitetônico

do Solar do Unhão e as atuais atividades do MAMB e MAP Unhão ", op. cit.

69 Id., "Exposições Museu Arte Popular 1963", Arquivo MAMB.

70 Id., Rascunho carta enviada a Celso Furtado em 05/03/64. 


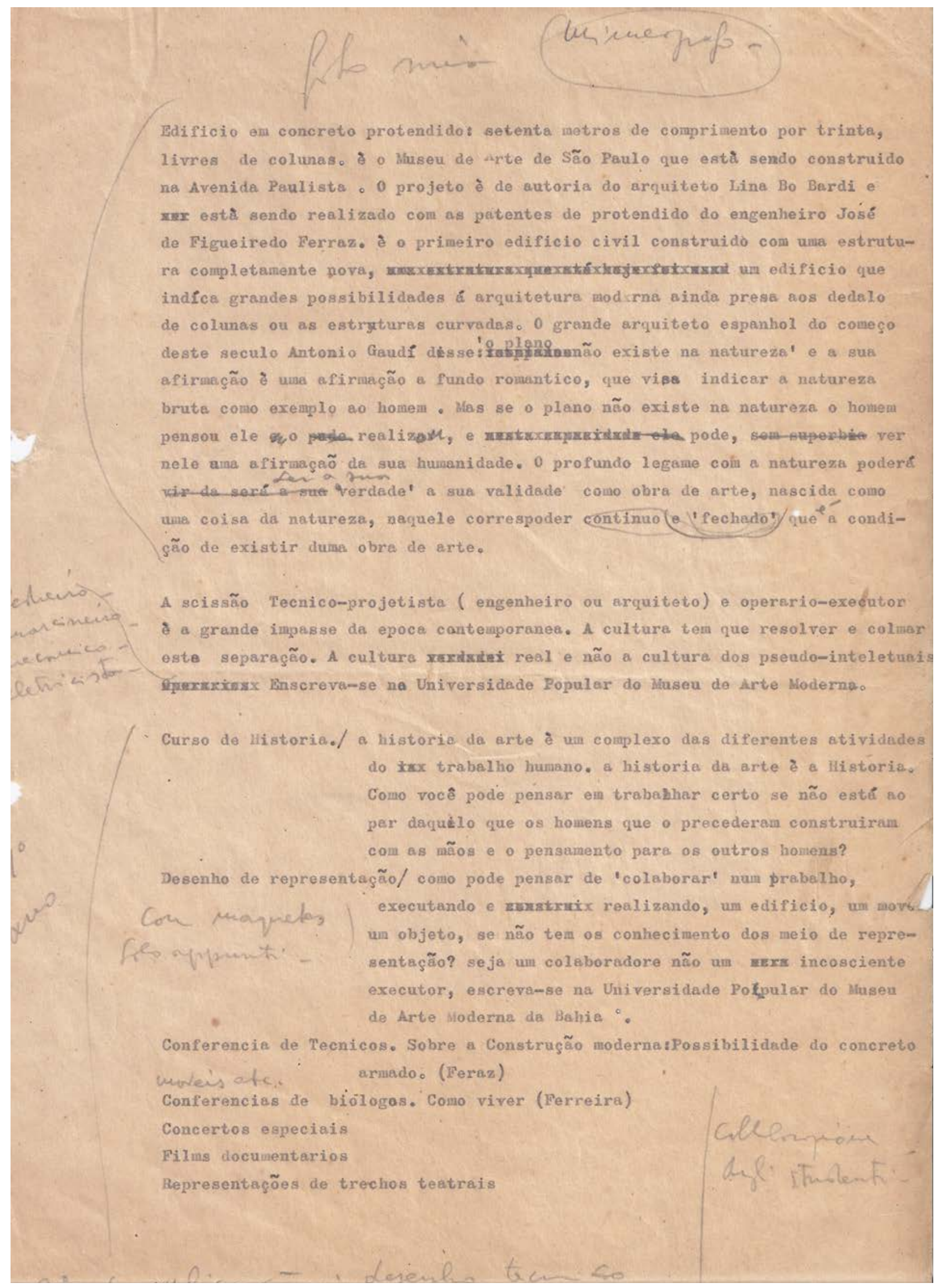




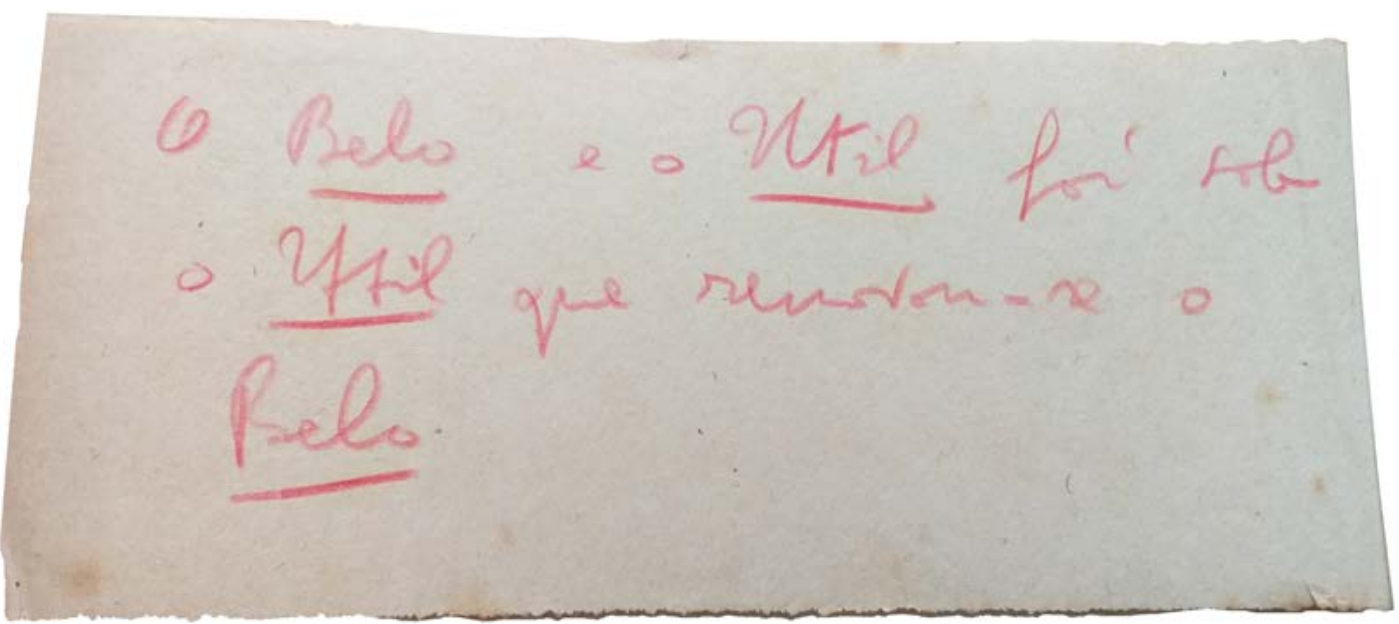

IMG 149.

Anotações Lina.

Arquivo MAMB. 


\section{Uma acusação}

Para inauguração da exposição Nordeste, em 1963, Lina reuniria artigos "pré-artesanais", objetos de uso diários, vestígios da simplicidade de uma existência, como colheres, panelas e redes, comprados na feira de São Joaquim, Água de Meninos, em Salvador. " Uma exposição paralela ao evento, Artistas do Nordeste, mostraria duzentas obras de cinquenta e sete artistas do referido "triângulo" - Bahia, Ceará e Pernambuco, com a presença inclusive do Centro de Cultura Popular do Recife. ${ }^{72}$ Se Nordeste ocuparia a Casa-grande, os Artistas do Nordeste ocupavam o quartel - memória do trabalho $-{ }_{, 3}$ expostas em rudes postes de madeira.

A escada de fatura artesanal de Lina dialogava com as inúmeras peças expostas vindas de um cotidiano rural, sinalizado em mapa, com seus núcleos artesanais produtivos. Assim, a exposição formalizaria um método de pesquisa das bases produtivas populares sinérgica ao projeto pedagógico do

\footnotetext{
71 Silvana Barbosa Rubino, em "Gramsci no Museu, ou uma arte popular não Solar do Unhão, Salvador 1963-64", op. cit. No arquivo "Exposições Museu de Arte Popular de 1963", mantido no acervo do Instituto Lina Bo e PM Bardi, mostra que paralelamente a exposição "Civilização do Nordeste" se desenvolveriam "manifestações populares, coreográficas e religiosas em teatro ao ar livre". Ainda, na programação, estaria "Arte Popular da Bahia", que seria realizada entre maio e setembro, como documentação musical, exposições populares ao ar livre e declamação de versos populares. Já "África-Bahia", entre setembro e dezembro do mesmo ano, contaria com uma feira gastronômica, além de música e tambores africanos.

72 Lina Bo Bardi, "Cinco anos entre os 'brancos'", Mirante das Artes, Etc. 6, op. cit.

73 Ver nota 45 deste capítulo.
} 


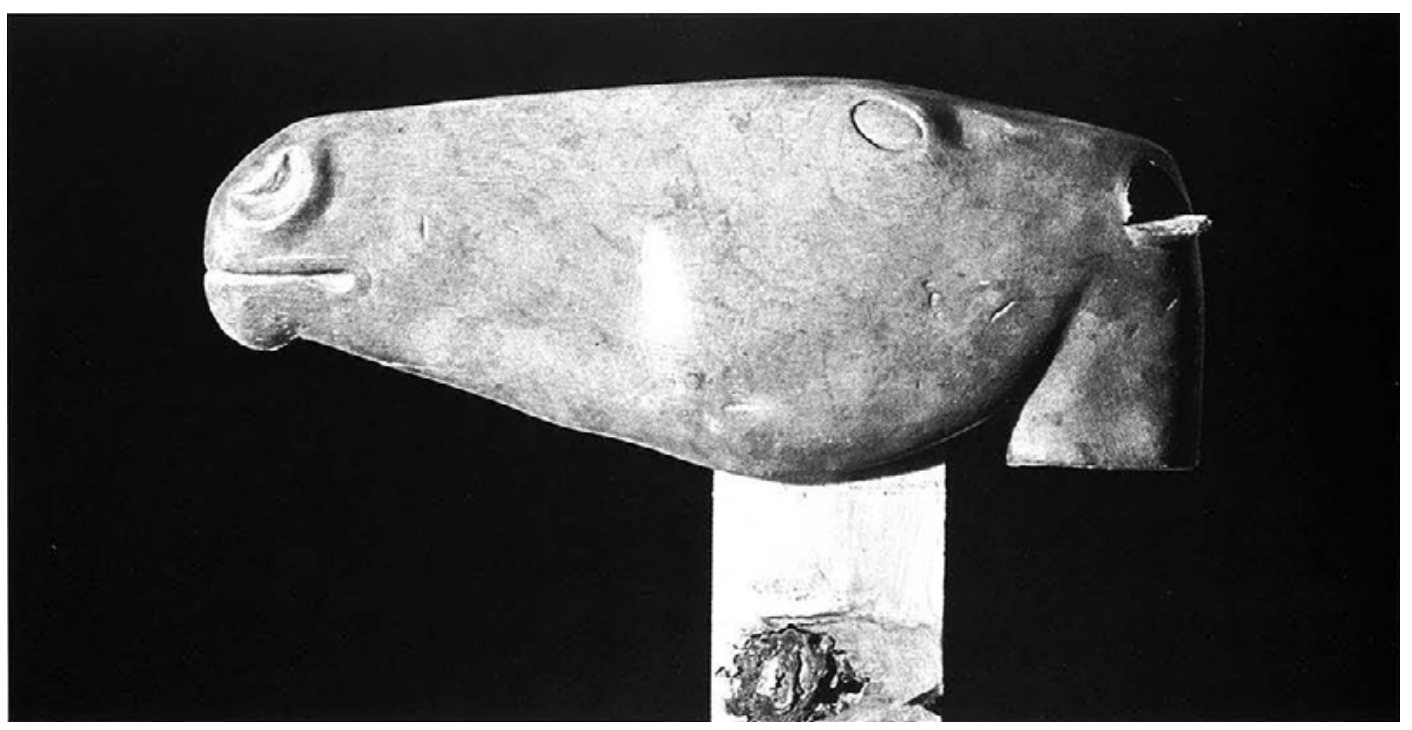

CETA, no desenvolvimento técnico de uma civilização, demonstrando o funcionamento conjunto entre museu, pesquisa e escola.

A exposição seria o ponto de inflexão para pensar o progresso articulado com a cultura nos modos do fazer. A partir da reprodução das feiras populares, seus objetos foram organizados em caixas e painéis de madeira: bules, colchas de retalhos, brinquedos, chapéus, colheres, pilões, carrancas do São Francisco, representantes de um mundo cotidiano e, portanto, de uma civilização. Agrupados em seus pares, os tipos se tornavam reconhecíveis, numa espécie de padrão de um mundo pré-artesanal que se afirmava interessado como um caminho possível, fundado em linguagem própria.

$\mathrm{Na}$ exposição NORDESTE, que inaugurou - Museu de Arte Popular em 1963, Lina expôs, junto a inúmeros outros objetos do cotidiano do Nordeste, principalmente do Sertão, as redes penduradas muito altas e inacessíveis, para serem olhadas de um ângulo improvável, ou para usar a expressão de Caetano, insuspeitadas. (...) Apresentavam muito mais o trabalho manual de sua feitura, principalmente da trama de suas varandas, do que a imagem do costumeiro objeto visto no ângulo habitual. Os demais objetos pobres eram apresentados de maneira também pobre, mas com fortíssima elegância expográfica - o que transforma o sentido de pobre para Lina -, perfeitamente amalgamada ao Solar do Unhão. Expor objetos do uso
IMG 150.

Cabeça de cavalo. Ex-voto.

[SUZUKI, 1994:18] 
cotidiano assim, deslocados, ready-made's em museus e galerias foi uma proposição das Vanguardas. ${ }^{74}$

A potência construtiva atrelava-se necessariamente à uma conscientização da alienação sóciocultural que estava no bojo da precariedade do sistema que a produziu. Latente no folheto que acompanhava a exposição, ${ }^{75}$ na liberdade aprendida no Nordeste, ${ }^{76}$ a denúncia sintetizava sua forma de entendimento da arte e seu adjetivo político: popular. A autenticidade da cultura passava por uma revisão de seus termos, deslocado da intelligentsia em sua compreensão de classes, na complacência paternalista que limitava os recursos formativos e o acesso e, assim, reiterava o sistema quando aceitava na deformação da matéria, o limite das formas e dos meios de produção.

No catálogo da exposição Nordeste, ao acentuar o lixo como matéria prima que inaugura o Museu de Arte Popular, Lina denuncia a falência de um sistema que sujeitava as economias entendidas como dependentes, as quais nada mais restaria enquanto produção senão os subprodutos da própria existência num "esforço desesperado de cultura": dos utensílios produzidos das latas de óleo e, até mesmo, de queijo cheddar, restos da presença americana no programa "Aliança para o Progresso". ${ }^{77}$

Esta exposição é uma acusação. Acusação de um mundo que não quer renunciar à condição humana apesar do esquecimento e da indiferença. É uma acusação não-humilde, que contrapõe às degradadoras condições impostas pelos homens, um esforço desesperado de cultura. ${ }^{78}$

Se a exposição Nordeste se impunha como manifesto que denunciava a miséria formalizada em desenho de uma necessidade de sobrevivência, Artistas recolocava uma

vanguarda ativa dos distantes territórios do sul. Ambas se impunham ao modelo de produção que a determinavam, seja no processo de formalização - grossa - e na presença imposta, assim como a Bahia que resistiu - e existiu - na grande bienal concreta brasileira

Segundo Suzuki, ${ }^{79}$ para Lina "a "civilização ocidental', devido às perdas gerais de comportamento que, segundo ela, ocorreram na Europa, não lograram chegar à grossura, não atingiram necessária grossura que, no entanto, já era endêmica no Brasil."
IMG 151.

Lamparina dobrável parede-mesa. [SUZUKI, 1994:25]

74 SUZUKI, Marcelo. Lina e Lucio. Tese de Doutorado. IAU-USP, 2010, p.269.

75 Folheto, s/d. Arquivo Lina Bo e PM Bardi, reproduzido em Lina Bo Bardi, op. cit., 158; e Tempos de Grossura: o design no impasse, op. cit., 35-37.

76 Lina Bo Bardi, "Solar do Unhão", em Lina Bo Bardi, op. cit., 153.

77 Programa para o desenvolvimento econômico-social da América Latina criado em 1961, dois anos após a Revolução Cubana, viabilizado majoritariamente com verbas norte-americanas. No Nordeste, destacaria a experiência de Angicos, com método de alfabetização Paulo Freire e o programa da ETUB, sob direção de Martim Gonçalves.

78 Folheto, s/d. Arquivo Lina Bo e PM Bardi, reproduzido em Lina Bo Bardi, op. cit., 158; e Tempos de Grossura: o design no impasse, op. cit., 35-37.

79 SUZUKI, Marcelo. Lina e Lucio. Tese de Doutorado. IAU-USP, 2010, p.285. 


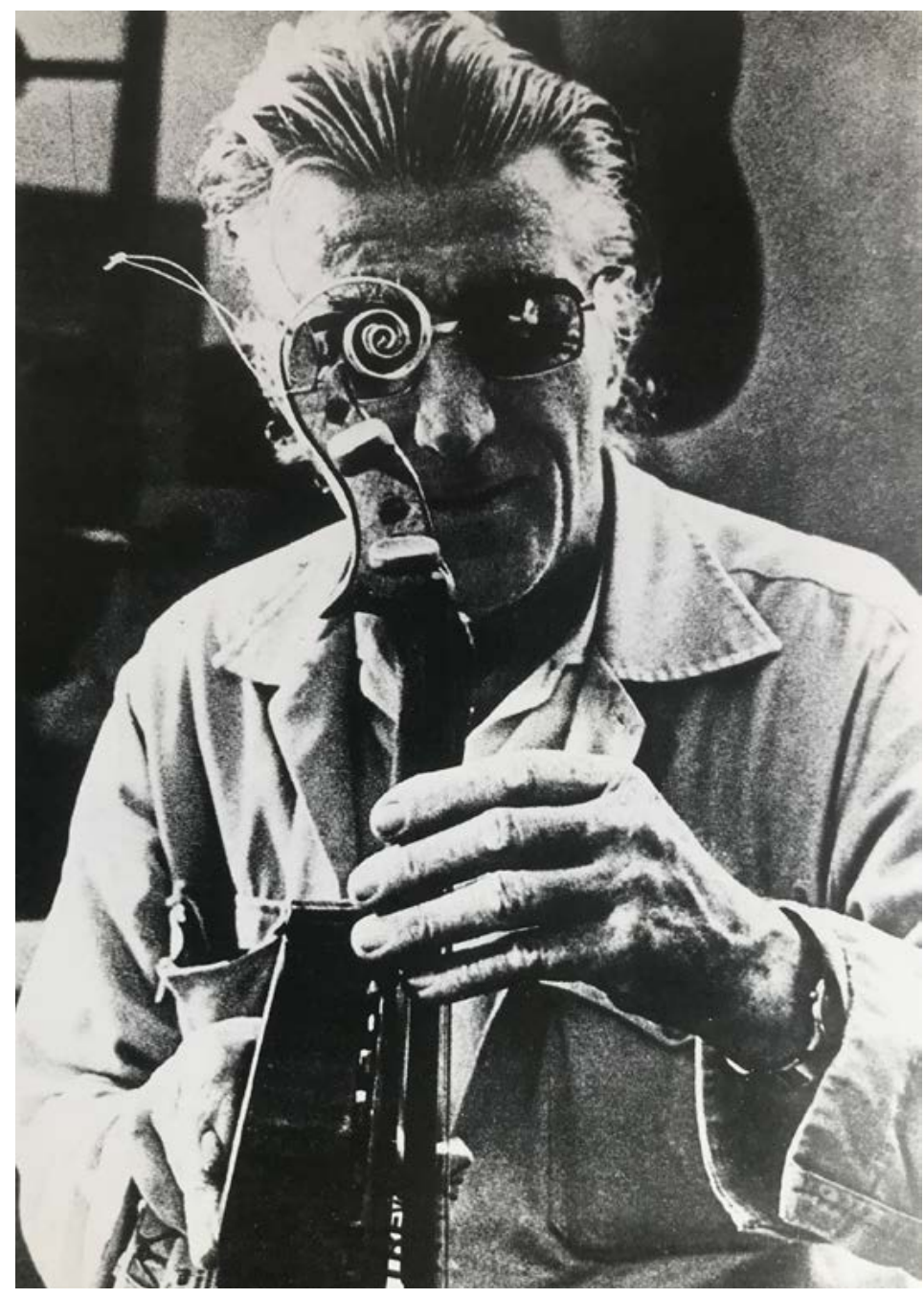

IMG 152.

Escultura musical produzida por Smetak. [RISERIO, 1995:álbum]
O que os homens conquistaram no decorrer dos tempos foi o progresso, a civilização sobreviveu ameaçada. (...) $O$ que o Ocidente tem feito, rigorosamente, até hoje é (...) separar o Progresso da Civilização, o que não aconteceu no Oriente. (...) Quem atravessa as Américas rumo ao Extremo Oriente sente nos grandes horizontes, na calma da Natureza (aparente, é terra de terremotos), que a opção do Progresso do Ocidente não é necessariamente a única, outras opções poderiam ter sido feitas, com os mesmos resultados. A opção escolhida pelo Ocidente deu resultados potentes, mas o custo é enorme. A América do Norte é América e, num certo sentido não é Ocidente, chegou tarde demais. Apesar dos esforços que querem demonstrar o contrário, um dia o povo da América do Norte envidará para seu verdadeiro caminho. Eram estas ideias que nos guiaram em fins de 50 e nos anos 60 . Nesse sentido, foi nosso esforço, nosso caminho.80

Na entrevista que Lina concederia aos estudantes de filosofia, em 1960, é possível identificar o processo de radicalização de um "caminho" delineado em sua prática em Salvador. Para Lina, o ambiente de tensões produtivas aglutinadas em torno do MAMB, apontava para a necessidade de superação dos "problemas culturais", no processo de formalização de uma linguagem autônoma. $O$ debate acerca das formas de produção e a economia levada à problematização no escopo das políticas públicas problemativaza a questão entre crescimento e progresso, nem sempre coincidentes.

A partir de uma visão técnica do mundo, Lina recolocava a questão estética de uma civilização em construção confrontada ao desenvolvimento de uma Arquitetura que se encaminhava "cada vez mais para uma fusão de arte e ciência", ${ }^{81}$ entre as necessidades de soluções harmonizadas com os ideias de uma estética e às certezas correspondentes ao progresso das pesquisas científicas. Sua experiência na Bahia a levaria

80 Lina Bo Bardi. FERRAZ, M. op.cit., p. 209. E propedêutica 81 BARDI, Lina Bo. Contribuição propedêutica ao Ensino da Arquitetura. São Paulo: op.cit., p.21. 
a radicalizar o processo de simplificação antevisto na produção material nordestina para a construção de um método fundado na síntese entre arte e técnica. ${ }^{22}$

Nesse processo de autonomia de linguagem que pressupões o projeto de simplificação, estaria uma resistência clara contra a apreciação folclórica da produção material realizada pelas massas e, consequentemente, um ataque ao reduto intelectual baiano que "sobre bases de importação pseudo-modernas", ${ }_{33}$ "segundo moldes provinciais", retardavam a afirmação cultural do Brasil. ${ }^{\text {st }}$

Lina apontaria, anos mais tarde, o conteúdo político iminente, cuja potencia antevista na cultura popular nordestina, alianhava-se às reformas de matriz nacionalistas que, dentro outros, se destavava na atuação dos Centro Populares de Cultura, em associação à União Nacional dos Estudantes, em 1962.

A situação apressada, o medo da classe dominante aumentava dia a dia: diante da agressividade dos estudantes, diante da possível explosão das fronteiras da antiga cultura acadêmica, cujo fantasma ameaçador era a Universidade de Brasília, em frente à alfabetização em massa, praticado com sistema de Paulo Freire principalmente por estudantes da UNE, contra a pressão a toda estrutura do país atingindo um máximo de auto-desenvolvimento dentro dos limites da antiga estrutura .

Assim, se o MAPU fora fundado sobre valores e interesses divergentes em relação à produção popular, a exposição Nordeste levaria ao confronto imediato das ideias reativas contidas no meio que se fazia presente. Frente à ousadia de seu projeto pedagógico e das palavras inteiras do seu posicionamento crítico estariam, na ocasião da inauguração, Lomanto Jr., governador do Estado da Bahia; Francisco Brennand, representando o governador

82 Id., "Técnica e Arte", incluído em "artes \& letras", Diário de Noticias.

83 Id., "Museu de Arte Moderna da Bahia", incluída na brochura de inauguração do Museu, e reproduzida em Lina Bo Bardi, op. cit. 139.

84 Id., "Cinco anos entre os 'brancos'",

Mirante das Artes, Etc. 6, op. cit.
IMG 153.

Brinquedo.

[SUZUKI, 1994: 14]

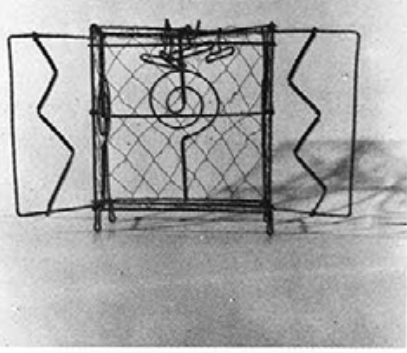

Armário de boneca, brinquedo. Arame e fio elétrico. Altura $20 \mathrm{~cm}$. Proveniência Maceió, Alagoas. Foto Arquivo Lina Bo Bardi
IMG 154.

Arte popular.

[SUZUKI, 1994: capa]

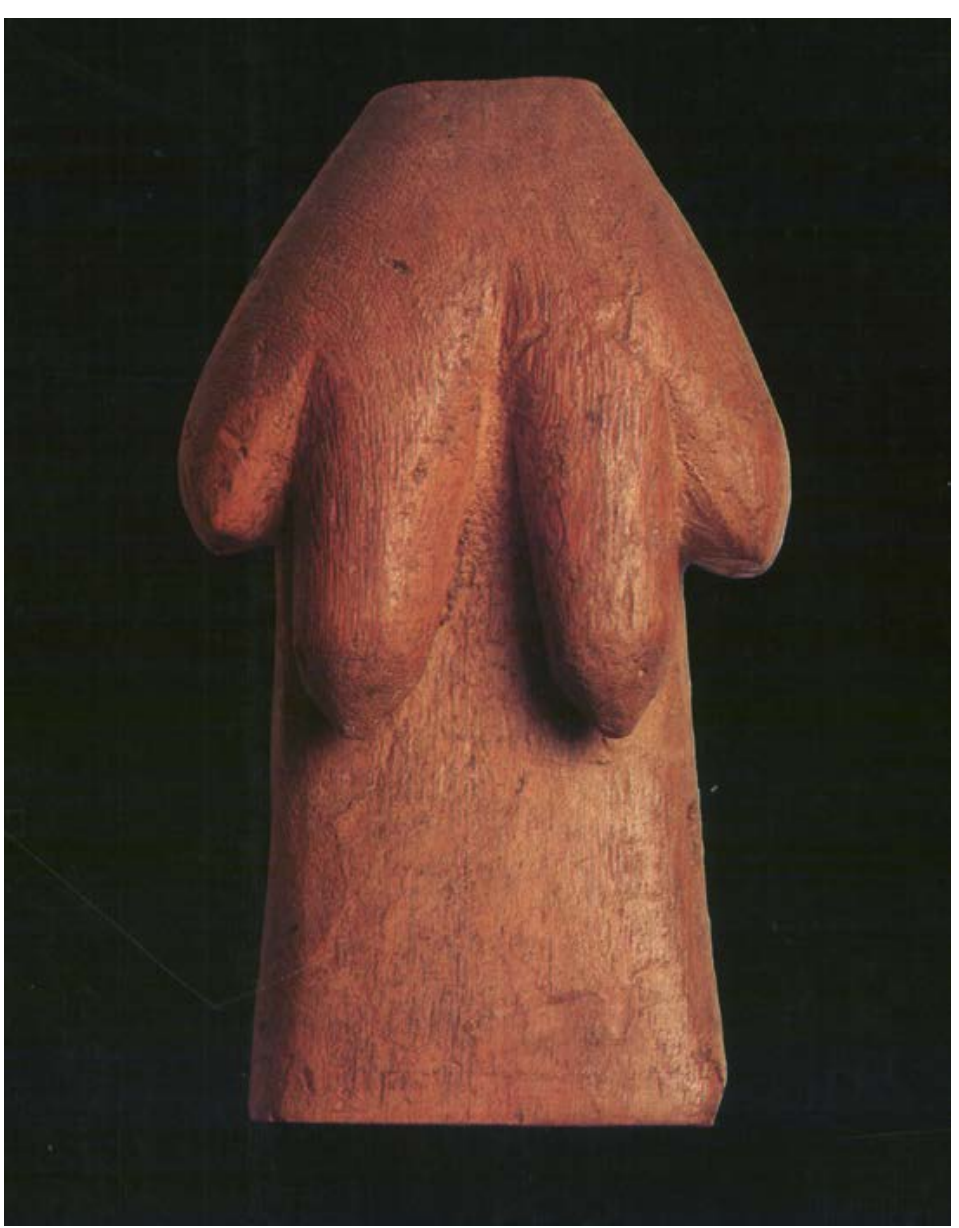




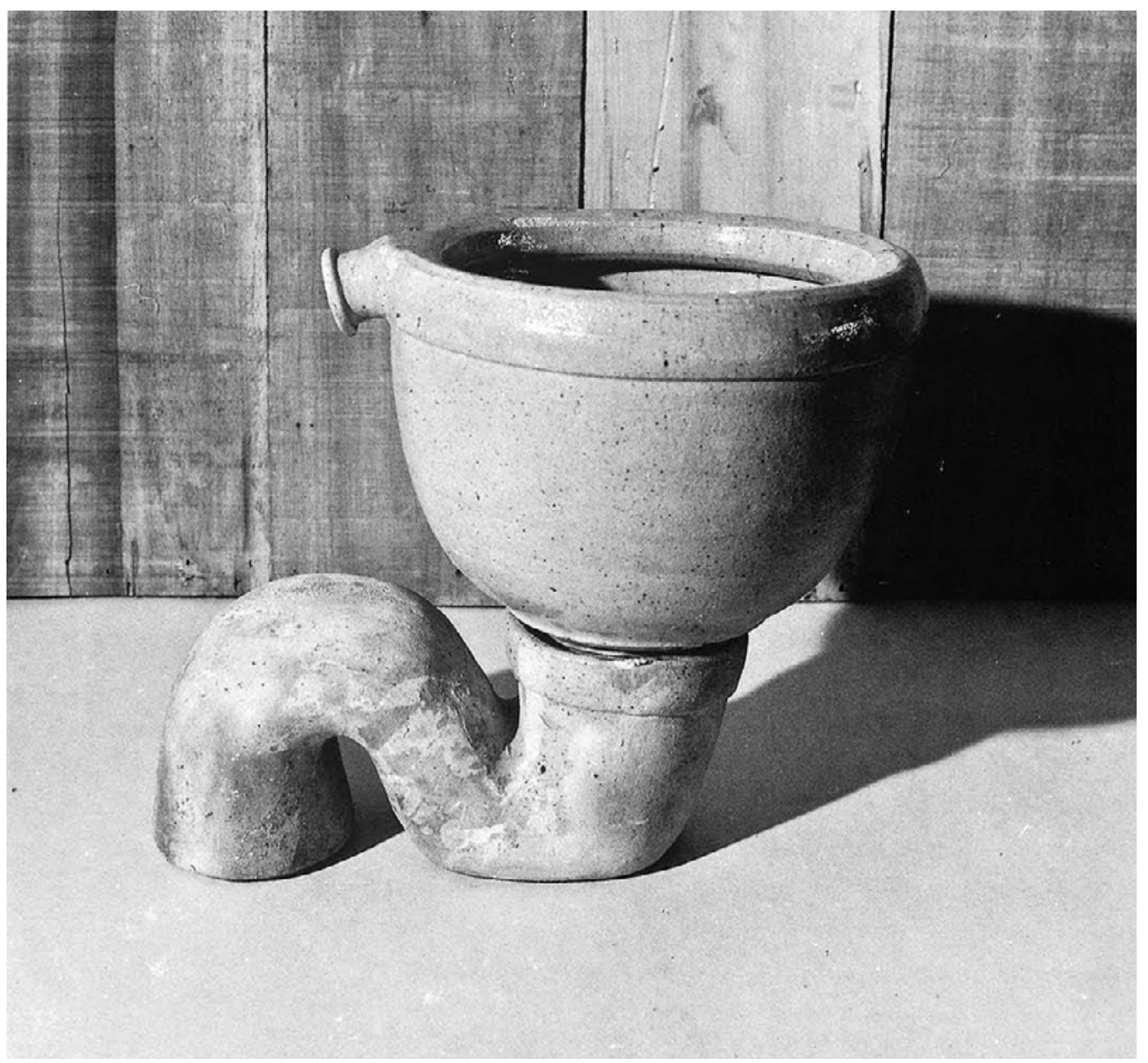

IMG 155.

Privada. Barro Natural. [SUZUKI, 1994:25] de Pernambuco, Miguel Arraes; Antonio Martins Filho, reitor da Universidade do Ceará; General Souza Aguiar; diversos secretários do Município; empresários, industriais, entre outros. ${ }^{85}$

A reação das elites locais ao trabalho de Lina foi imediata e golpe militar de 1964 encerraria essa experiência com tropas militares ocupando o Museu de Arte Moderna da Bahia. Para além do exército, Lina atribuiria o encerramento de suas atividades à resistência de uma intelligentsia local conservadora intimidada com sua circulação nas instâncias de poder local e à tentativa de aproximar seu projeto de uma cultura crítica e autônoma ao impulso socioeconômico que repensava as formas de produção no Nordeste brasileiro, ${ }^{86}$ suas políticas de subsídios e programa estético-pedagógico.

Com uma visão bastante aguda do processo reativo da sociedade civil que engendrou o golpe de 1964, Lina aponta a preponderância de uma estrutura de poder centrada numa submissão secular: "O que aconteceu em $64(. .$.$) não foi,$ como pode parecer, que o Regime Militar

85 "Inaugurado o M.A.P. Com duzentas obras de arte e mil trabalhos de artesanato", A Tarde, 4 de nov., 1963.

86 Lina enfrentaria também a distância de seus apoiadores iniciais, seja na omissão de seu assistente Sante Scaldaferri na ocupação do MAMB pelas tropas militares, na consequente nomeação de Mário Cravo Júnior como o novo diretor da instituição, mesmo Brennand, cujas diferenças ideológicas se acentuariam nos anos de chumbo. Na ocupação do MAMB, a VI Região Militar faria uma exposição do material subversivo apreendido no Nordeste, entre 30 de julho e 23 de agosto de 1964 e sua inauguração contaria com a presença do governador Lomanto Júnior e do diretor dos Diários Associados na Bahia, Odorico Tavares. 


\section{UMA ANIECIPACÃO BAIANA DA POP-ART}

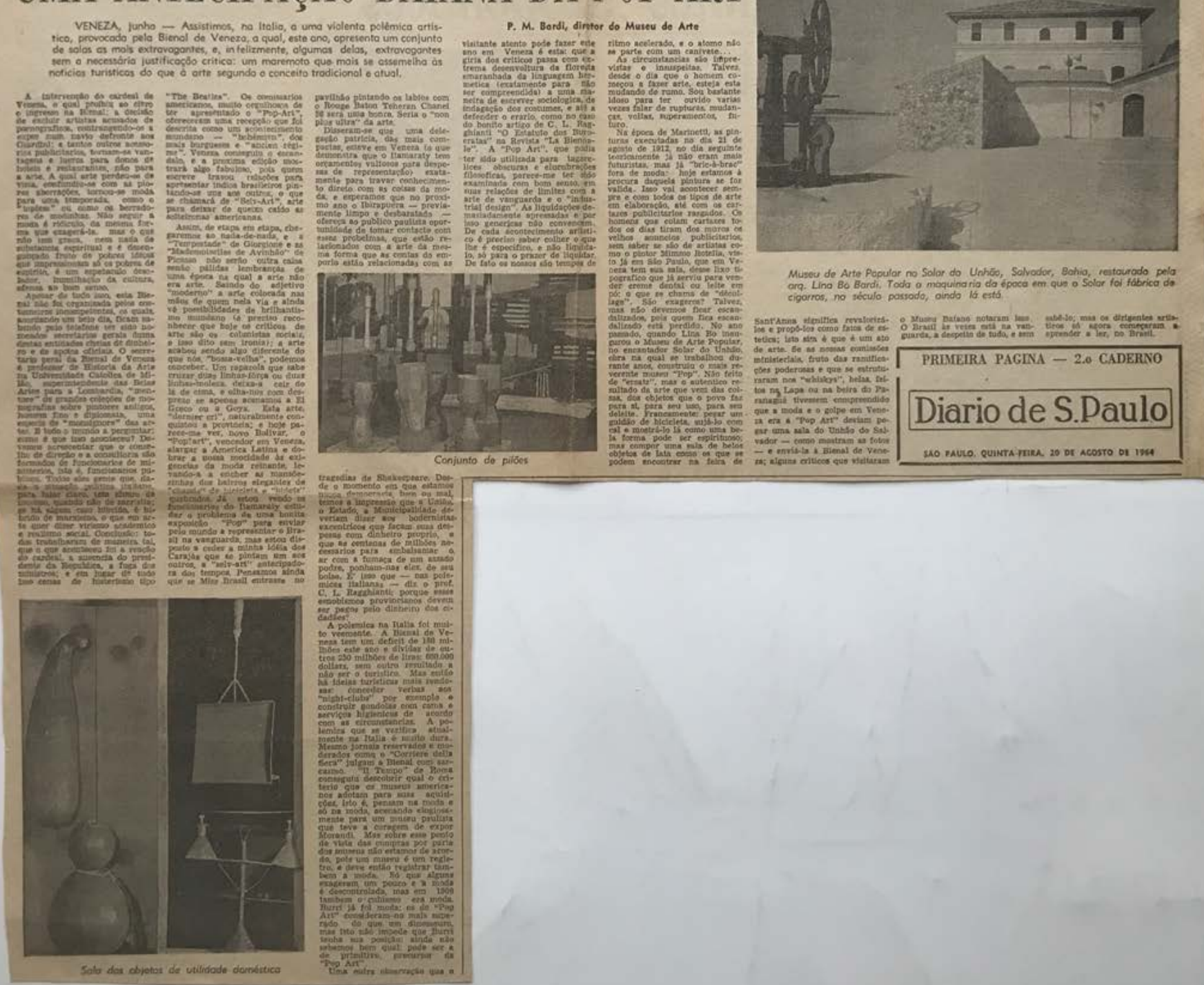

assumiu o controle do país. Foi a reação civil, que ainda está e que vem de outras raízes, mesmo fora do país. Os militares deram uma ordem e, é claro, quando algo violento acontece, há tortura, prisão, morte, como em qualquer país do mundo. Essas pessoas perigosas, que a reação civil ainda está no poder hoje", relataria em $1990 .{ }^{87}$
O Ocidente está à beira de uma revisão total. Eu acho que o Brasil não faz parte do Ocidente. É África! Graças a Deus o Brasil está fora do Ocidente que, afinal, é pobre. O Ocidente depois da II Guerra Mundial está minguando. Tudo aquilo que era elegância, o refinamento, as coisas gostosas... sumiram. Isso não pode nem deve ser visto como uma grossura, mas sim como uma miséria moral. ${ }^{\text {sa }}$

87 Lina Bo Bardi, Arte na Bahia. Teatro na Universidade, op. cit.

88 FERRAZ, M. (org). Lina Bo Bardi, op.cit., p.203.

Uma antecipação baiana da pop art. [Diario de S.Paulo, 1963] 
Fista exposição desenvolve temas enunciados na exposição Bahia apresentada em 1959 na V Bienal de São Paulo em colaboração fom o prof. Aisrtim Gonçalves então diretor da Escola de Teatro da Universidade da Bahia.

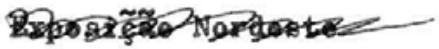

Esta exposição que inqugura o Museu de Arte Popular do Unhão deveria-se chamar ìx Civilizą̧̃o do Nordeste。 Civilização。 Procurando tirar da palarra o sentido \&ulico-retorico que a acompanha.Civilização \& o aspecto prético da cultura e̊ a vida inteira dos homens gm todos os istantes.Esta exposição procura apresentar uma civilização phanejada en todos os detalhes, fstudada tecnicamente, ( mesmo se a palavra tecnico mprexsa define aqui un trabalho primitive), desde a apenedbeso iluwinação aos colheres de cozinha, às colchas, ds roupas, bules, brinquedos, moveis̆, armas.E a procura desesperada e raivosaiente positiva de homens que não querem fer demitiog que reclamam seu direito $\mathbf{t}$ vida. Una luta de cada istante para não afundar no desespero, uma afirmação de beleza conseguida con o rigor que somente a presença constante duma realidade pode dar.

Materia prima:

Lampadas queimadas, recorte de tecidos, latas de lubrificante, caixas velhas e jornais. Cada objeto risca o limite do 'nada' da miseria.Este limite e continua - martelada presença do 'util' e 'necessario' Ẽ que constituea o valor desta produçaõ, sua poética das coisas humanas não-gratuitas, näo criada pela mera fantasia. E neste sentido de moderna realidade que apresentamos criticamente esta exposiçäo. Como exemplo de simplificação direta de formas cheias de eletricidade vital. Formas de desenho artesanal e industrial. Insistimos na identidade dbjetofartesanal $\Rightarrow$

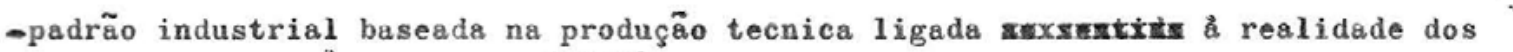
materiais e nảo h⿱⺌兀 Popular e nẽ de Folklore por ser o folklore uma herança estatica e regressiva, cujo

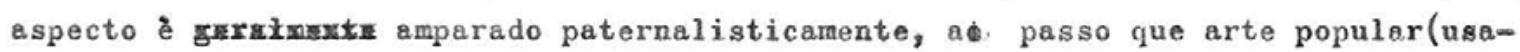
mos a palavra arte não somente no sentido artistico mas tambem no de fazer tecnicamente) define a atitude progressiva da cultura popular ligada a problemas reais。 Esta exposição quer ser um convite para os jovens considerar msx o problema das raizes 'nacionais' da cultura, fora das limitações 'nacionalistas', qo potblema da'sim-

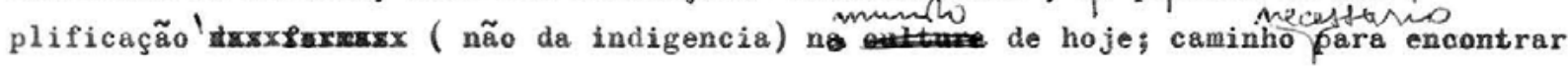
dentro do humanesimo tecnico, uma poética.

Esta exposição è uma acusa.

Acusa dum mundo que não quer renunciar è condição humana apesar do esquecimento e da

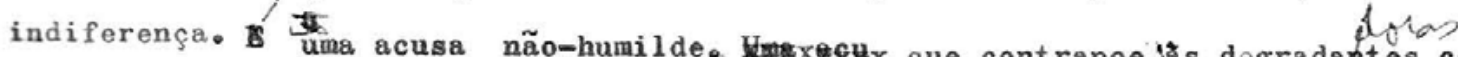
impostas pelos homens, um esforço desesperado de cultura.

Lina Bardi

IMG 157.

Rascunho Exposição

Nordeste, 1963.

Arquivo MAMB. 


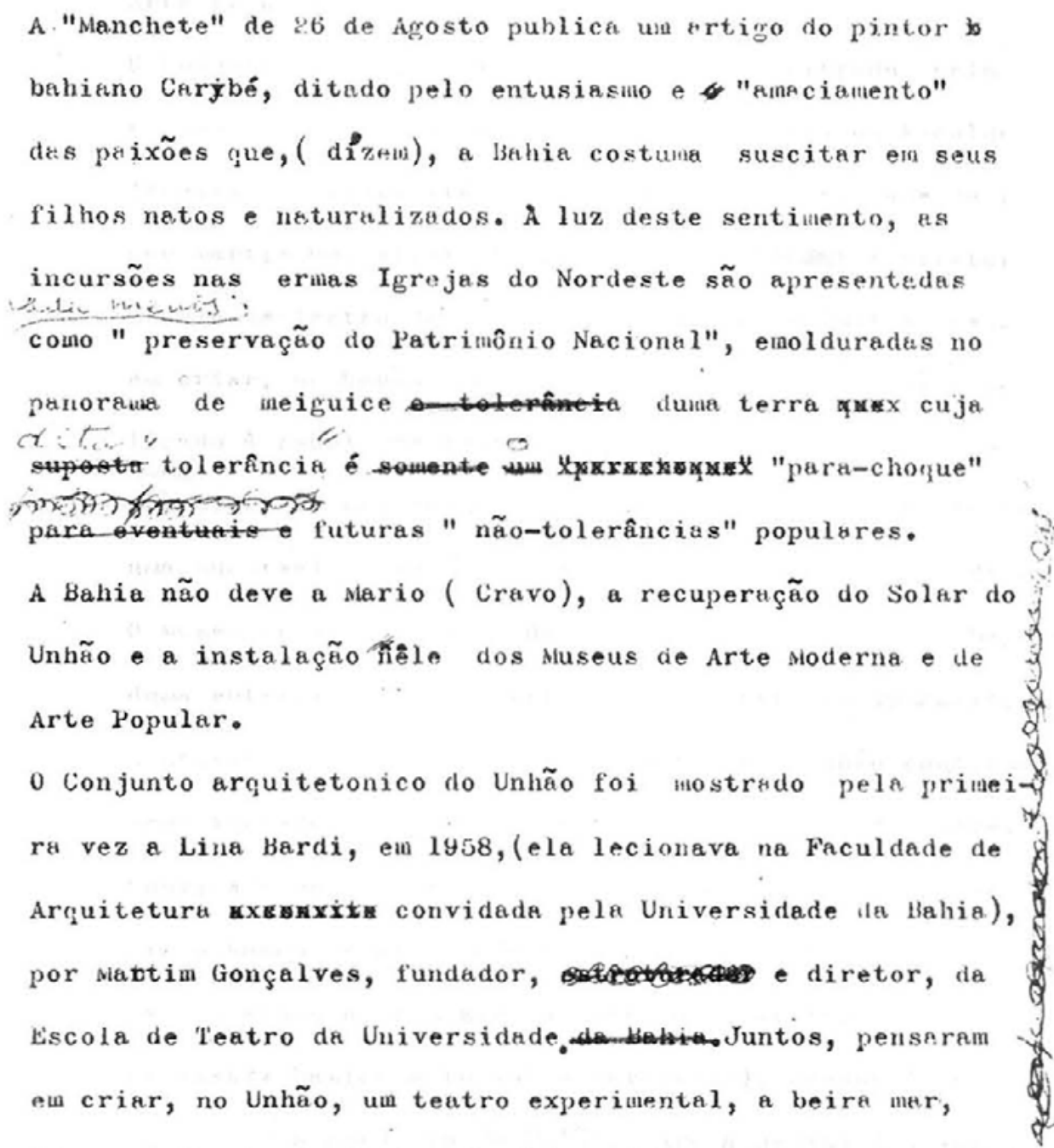

ligado à Escola de 'Teatro dn Universidade . Frierma do projeto - Ciccillo metarazo que najuele tempo estuva instalundo ulia sucursal do Mérlurgica na Bahis, e era emigo deles. O Museu de Arte moderna da. Brhir aindr ñ̃o existir.Depois dunk entrevista con o Keitor da Univorsidede, Bahág Edgar Shutos, Ciccillo desistiu do projeto, e o Unhr̃o cortinuou cor seus inuaeros inguilinos e seu deposito de inflataveis. Convicuada pelu governo do Estudo, ou lyby pura fundar e diriEir o buseu de Arte inodernt dn bahin, lina liarui, ( que

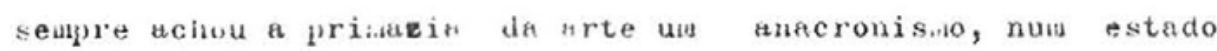
attammog basicamente subiesenvoivinof, pensou logo eu 


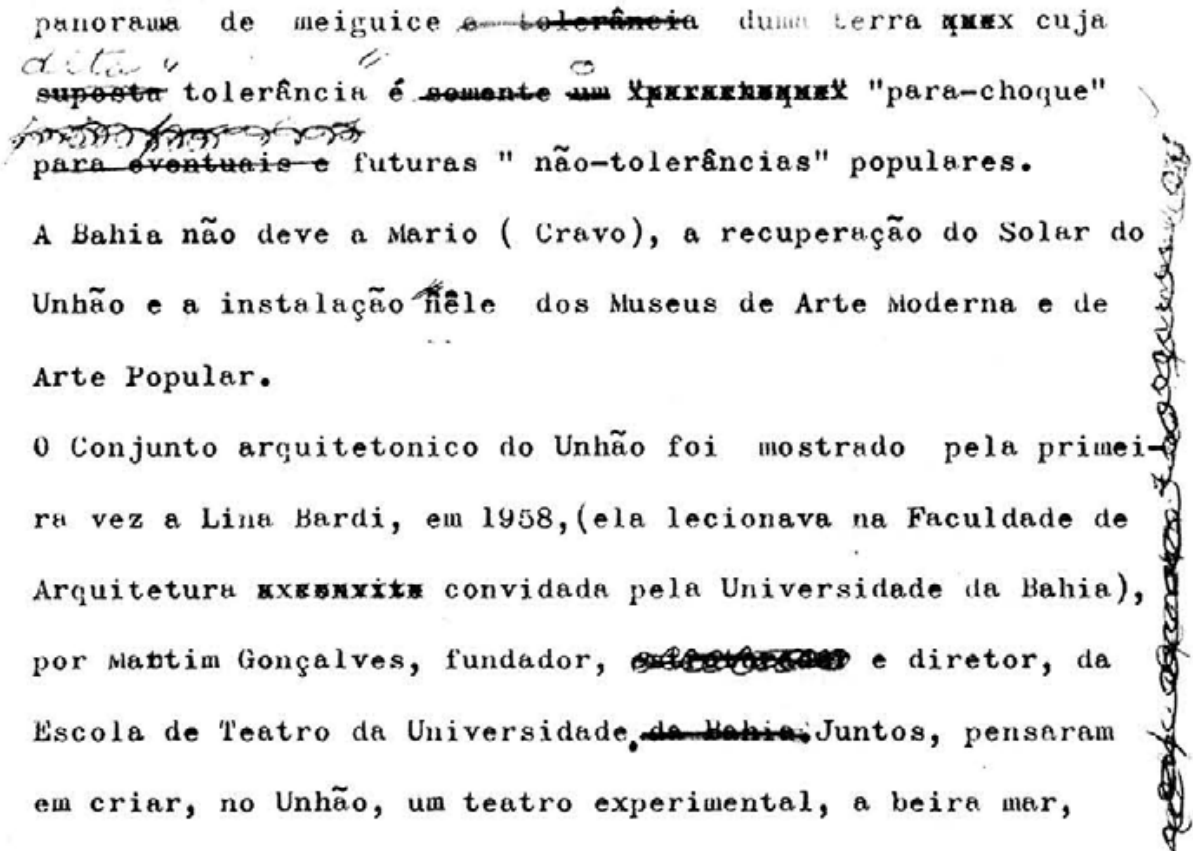

ligado à Escola de Teatro da Universidade .Falarem do projeto Ciccillo matarazo que naquele tempo estava instalando uta sucursal do Me:alurgica na Bahia, e era amigo deles. 0 suseu de Arte moderna da Bahia ainda não existia.Depois duma entrevista com o Reitor da Universidade, Edgar Suntos, Ciccillo desistiu to projeto, e o Unhão continuou cor seus inumeros inguilinos e seu deposito de inflamats. Conviciada pelo governo do Estrdo, 10,59 para fundar e dirigir o hiuseu de Arte moderna da Bahia, Lina Bardi, (que sempre achou a priaarin da arte un anacronisuo, nuis estado attmante basicaueute subdesenvolvido), pensou logo em recuperar o conjunto do Unhr̃o, park a definitive instalą̧̃ do museu de Arte Noderna e $\$ \not^{2}$ huseu de Arte Popular( Univar sidade Popular para o conversão do artesanato ea desenho incustrial), segaindo os conselhos de llomulo Allieida, secre-

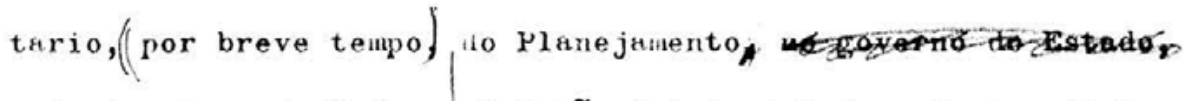
e de tecnicos du Surlene. O Unhỡo foi instalado pelo arquiteto Lina Bo Bardi na mais deserta solidão, entre os ataques da "Inteligência" bałrixnx local que tinha conseguido : saida

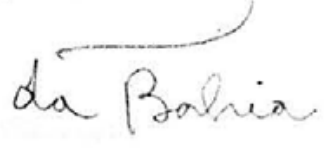


Aschn de Martim Gonçalves, cuja intrensigência e cuitura incoinodava/profundamente os "Bonos do Assunto " locais, o escultor Mario Cravo tinha viajado meses antes, para longa temporada na Alenanha 0cidental, a convite da plo $^{2}$ Foundationg. Lina Barii inougurou o Museu d $\mathcal{Q}$ Unhão em Iovembro de 1963, com uma grande exposição de Arte popular Nordestina, auxiliada por Livio Xavier, então diretor do Museu de Arte da Universidade do Ceará, e pelo xas Centro de Arte Popular do Recife. taxkioxix ( frente a nova situação politicu) do secretario do Museu, e pela covardia)da diretoria, que se $x$ do 1/ejer, apressou em nomear Mario Cravo seu sucessor, Lina Bardi foi obrigada a interromper sof trabalho e deixer o poroleste. As condições politicas do País já não permitian mix a existencia duma Universidade Popular, e o Unhão devia ser transformado, o mais depressa possivel, num centro artesanal provedor de lem-

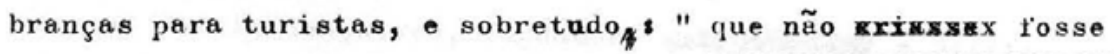
fonte de problenas".

Esta é a historia do Unhão, Museu de Arte Moderna e Arte Popular da Bahia, é a historia da Escola de Teatro da da Universidade de Brasilia, da Sudene... e mais, e mais, e mais.. ................... e mais......

Até quando?

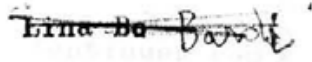




\section{ITALCABIF}

RIO DE JANEIRO - Hua Buenos Aires, 44 Tel. 23-1996 $\begin{array}{ll}\text { Agencias: Castelo - Rua Mexiç, } 11 & \text { Tel, } 32-8850 \\ \text { Copacabana - Av. N. S." Coópucabana, 245, L., C. Tel. 37.5525 }\end{array}$ Mati - Av. Rio Branco, 9, loja Tel. 43-9051 Avenida - Eid. Av. Central, loja 129, 1."e sobsolo Tel. 23-1996

SANTOS - Rua 15 de Nowembro, 131/3 2-9365 - 22.2000 - 2-9055 Sto PAULO - Rua 15 de Novembro, 164 géncias: Gajeria Itapetininga. loja 5 . Ar. Silo Jo40, 1.23 , Tel. 37.5136

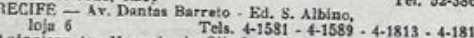
Hotel Bos. Marquès de Olinda, 142 The

TELE GR A M A

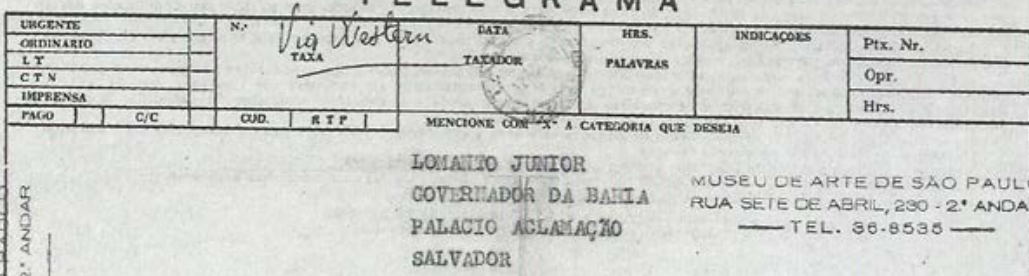

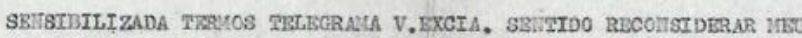

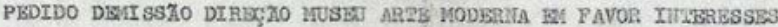
CUL2URAIS BAFIA AFIRUKO ABSOLUIA IMPOSSTIILIDADE RBCOTSIDERAÇO DADA IUPOSSIBILIDADE RESTABELBGER COHDIÇOES IRACESSARIAS OBJEYIVOS CULTURAIS BI MUSELLOGICOS COIISACRADOS SHOP APELO V.EXCIA SORITAR PUBLICO

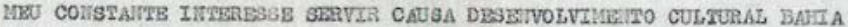

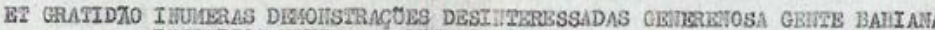
Estando de acordo com as condiçóses estabelecidas no vo BARD.

Assinatura do Expedidor

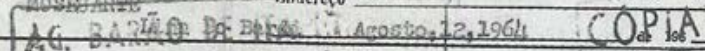


JULIANA VILLELA JUNQUEIRA

Propedêutica da grossura 


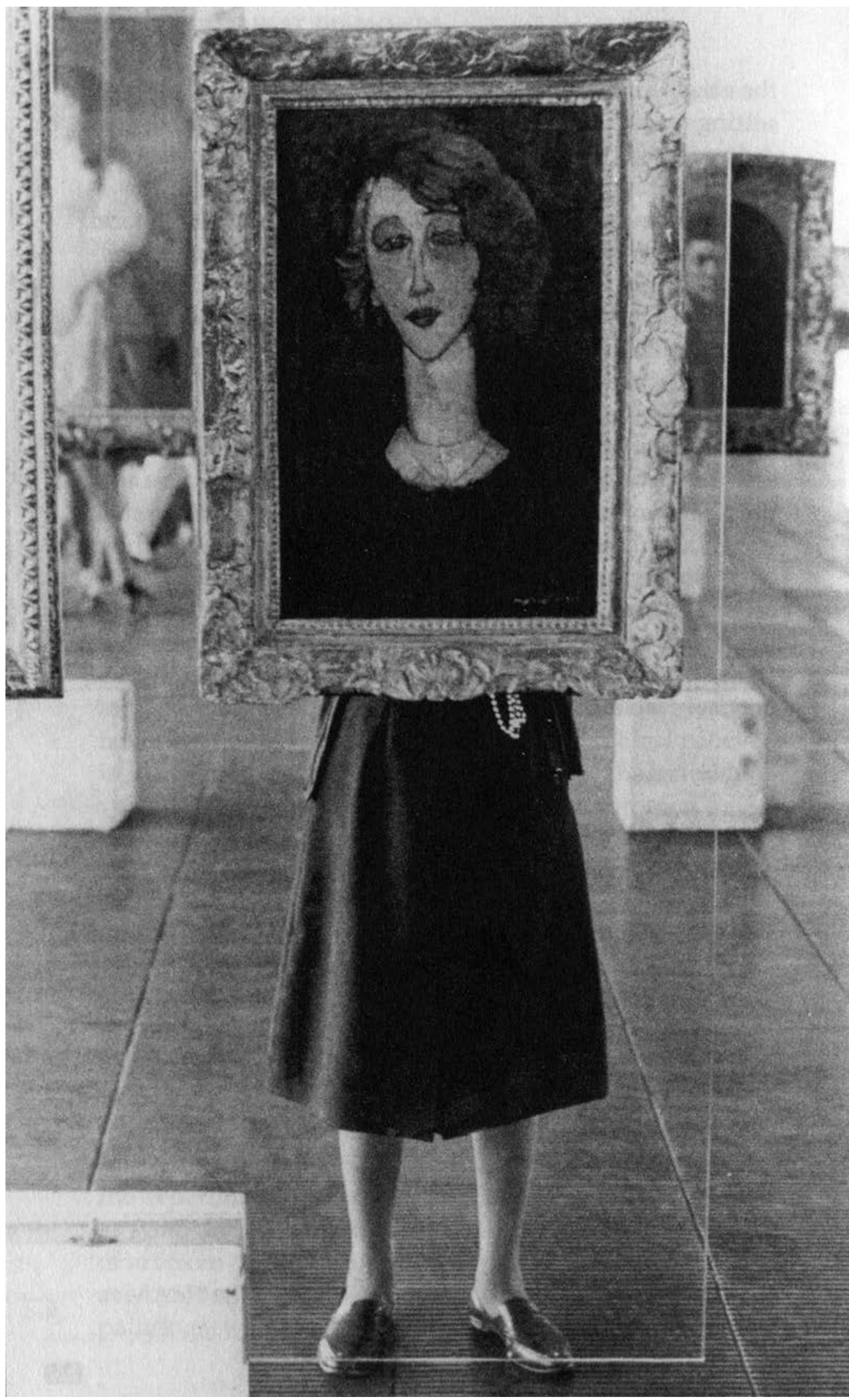

IMG 160. 


\section{Etnografia}

versus

\section{Projeto}

CONSIDERAÇÕES

FINAIS
A passagem "De madame à beatnik" é imagem-síntese cunhada por Risério para desvelar uma transformação que se estende à praxis de Lina, diante da potência da cultura negro-mestiça, matéria de um movimento constelar atribuído por ele como vanguarda, nas décadas de 1950 e 1960, na Bahia.'

Poderíamos pensar em outros binômios possíveis desdobrados desta aparente subversão: Roma-Milão, Itália-Brasil, Bardi's Bowl- Cadeira de Beira de Estrada, Casa de Vidro-Casa do Chame-Chame, São PauloBahia, numa crescente que se acentua num movimento de aproximação de uma massa de "contribuição indigesta, seca, dura de digerir". A catarse cairia bem ao Oficina, quando nos deglutinaria às avessas, produzindo o melhor teatro do mundo, segundo o The Guardian. ${ }^{3}$

De volta a imagem geradora, àquela do vestuário que informa a fala do corpo, numa espécie de travessia epifânica, clássica narrativa de viagem, a personagem na Terra do Sol enfrenta o Liso do Sussuarão. Mas de Manuel e Riobaldo, Lina carrega uma distância substantiva: está do outro lado da história, na chave da invenção. ${ }^{4}$

Afeita às narrativas dignas de um curriculum literário, Lina definitivamente não

1 RISÉRIO, Antônio. Avant-garde na Bahia. São Paulo: Instituto Lina Bo e P.M. Bardi, 1995, p.123.

2 BO BARDI, Lina. "Um balanço dezesseis anos depois", em SUZUKI, M. Tempos de Grossura, São Paulo, op.cit., p.12.

3 "The 10 best theatres". Em The Guardian, dez., 2015.

4 Luis Antônio Jorge. "A posse possuída: o encontro marcado com o sertão". op.cit. 
foi um personagem. Ainda que hoje sua imagem esteja associada aos gadgets para consumo, nas mesmas "lojinhas para turistas", cujo pavor advertiu a Celso Furtado - num tempo em que se discutia cultura no bojo das políticas públicas.

E na concretude de que falamos, a energia de sua atenção estava no mundo cotidiano, espaço onde passado e futuro se sobrepõe num presente contínuo irrestrito formalizado em ação. Sua práxis é potência no ato.

Mais produtivo do que discutir a nacionalidade de sua prancheta - evidente que seus projetos se desdobraram aqui e não em outro lugar - interessa embarcar na navegação das ideias dos conceitos que lhe são chave e, muitas das vezes, nos são caros.

Os binômios iniciais - transatlânticos, inclusive -, mais se assemelham a pares complementares, permeáveis, até. Sem precedentes, em seu sentido lógico, sua obra não evolui como um organismo entrópico, nem atinge a maturidade insujeita de um beat tropical. Seu modus operandi é a presença, daí a dificuldade em capturá-la em um só tempo e um só lugar.

Invalida também o tempo linear - invenção do Ocidente - e, de uma equação simples, em que X, Itália, mais Y, Brasil, produz um resultante esperado, passamos ao cálculo diferencial, com suas variações de grandeza e acumulações de quantidade. E nesse "maravilhoso emaranhado onde, a qualquer instante, podem ser escolhidos pontos e inventadas soluções, sem começo nem fim", ${ }^{5}$ é preciso ver Lina em sua historicidade, para que se tenha a justa medida da potência de suas ações. ${ }^{\circ}$

Intelectual europeia de sólida formação, Lina dedicou-se à ação didática em um país "de enormes possibilidades", na construção político-estratégica aprendida com Gramsci, desvelada na forma de agir institucionalmente, em defesa de um progresso articulado com a cultura.

De Gramsci, fica a atenção ao nacionalismo que nos espreita. Nem tudo que Lina procurou na Itália, estava no lugar "onde tudo era possível". Mas entre o revés oswaldiano da exofagia (ainda na chave do desconcertante "outro" que nos devora) e o complexo vira-lata daquele que aceita miserável as barriadas, reside o espaço defendido por Lina: o da circulação das ideias.

No ponto de inflexão em que a "ameaça externa" transitava do fascismo ao imperialismo ianque, viver sob a República de Salò lhe concedeu a chancela prévia, forjada em liberdade, de absorver aquilo que de melhor existia na democracia norte-americana figurada na experiência do MoMA, modelo pedagógico de museu e institucionalização de patrimônio recente para suas ações tanto em São Paulo, quanto na Bahia.

Se seu olhar estrangeiro convoca o permanente estado de julgamento, necessário para apreensão das "ideias fora do lugar" descrita por Schwarz, ${ }^{7}$ seu ferramental de matriz etnográfica opera a partir de suas categorias de formação, o mundo europeu - o que evidentemente não poderia ser outro. E é nesse sistema que termos como "primitivo", "pré-artesanato", "folklore" e, mesmo, "cultura" devem ser redimensionados em seus sistemas de valores. Afinal, para qual civilização Lina está olhando? Quando diz que somos África ou quando aponta que talvez devêssemos olhar para o Japão como processo de industrialização, fica claro seu questionamento acerca da possibilidade de um mundo ocidental nos trópicos. Ou ainda, uma revisão deste mundo e seus termos.

E se, então, não somos ocidentais, ou melhor, se não deveríamos ser ocidentais ou ainda, se então pudéssemos ser ocidentais de uma outra forma, qual o valor da palavra "pré-artesanato"? Qual o valor do termo "primitivo"? O que pode ser atribuído como primitivo numa produção que lhe é contemporânea? Sob quais sistemas de valores se poderia pensar a produção industrial no Brasil? E nessa pergunta que embaralha tempo e espaço, mais um binômio complementar: ocidente e oriente, cujas categorias de pensamento se misturam numa chave aberta, permeável ao pensamento crítico, mirando outros valores, existentes ou imaginados - talvez mais

5 BO BARDI, Lina. Em FERRAZ, Marcelo Carvalho (Org.). Lina Bo Bardi. São Paulo, op. cit., p.327.

6 Ver Belluzzo, Ana Maria."Exposição A Mão do Povo Brasileiro". Palestra IEA, 07 de nov. 2017.

7 Roberto Schwarz, "Ao Vencedor As Batatas", São Paulo: Duas Cidades, 1992. 
próximos [por que não?]

Sua insurgência contra o folclore, escrito sempre folklore para acentuar a origem, está mais próxima do pesadelo russo de Majakovskij, ${ }^{8}$ do culturalismo obscurantista fascista e, até mesmo da "macumba-pra-turista" de Oswald, do que do folclore de Câmara Cascudo e Mário de Andrade. Um abismo ainda a separaria de Monteiro Lobato. Da mesma forma, sua etnografia política não impediu a ironia de estar "cinco anos entre os brancos"." Selvagem, pois bem, era a elite agrária e seu exercício sobre o Estado e a vida cultural do país, cujo limite se daria na interrupção de seu próprio trabalho, sempre contra os efeitos da herança oligárquica sobre o mundo popular.

Contra também ao senso de privilégio burguês que situamos a posição antifeminista do architetto, antes que a incômoda leitura feita por Cildo Meireles, na voz imperativa de Pietro ordenando "Lina, va fare un caffè!", ${ }^{10}$ nos apresse em conclusões desmesuradas. É preciso reconhecer os meandros sutis, carregados de potência, entre o fascismo revolucionário do Professor e o stalinismo de Lina, sob o crivo humanista e sua relação com o universo popular - sobretudo no sentido de não o elevar ao gosto burguês. A contribuição fecunda da parceria que estabeleceram sintetiza o refinamento de uma agenda pedagógica fundada na crítica e nas potencialidades máximas de um país em vias de desenvolvimento.

De Riegl, trouxe a equidade entre as artes ditas maiores e menores, antevistas no esforço de suas exposições didáticas. E se "arte pela arte" é apenas uma abstração desinteressante, qual o significado do adjetivo popular ao substantivo arte? Menos uma hierarquia relacionada a um estágio a ser superado, o popular é visto no entendimento do sistema que o produziu. Interessa não apenas as relações problemáticas entre arte e produção, mas o entendimento de um sistema possível em condições mínimas de sobrevivência. Interessa a noção de trabalho atravessada por trezentos anos de escravidão. E afinal, quais implicações dessa organização social em nossa cultura material?

Dois anos antes do lançamento da revista Habitat, com o propósito de desprovincializar as distâncias entre Rio e São Paulo, Lina convida Oscar Niemeyer para integrar o comitê editorial, confiando na sua capacidade de "seleção e intransigência no material [a ser] publicado". ${ }^{11}$ Oscar, por sua vez, declina frente ao arroubo de uma estrangeira que "complica demais", 12 dedicando-se ao projeto carioca, não menos importante, da revista Módulo.

Essa resistência às suas ideias não foi um fato isolado. Tampouco se restringe aos estereótipos de origem, ou de gênero. $\mathrm{O}$ pensamento crítico intrínseco a sua forma de projetar, e de se projetar no mundo, trouxe os mais diversos embates. Dos anos de formação sob o fascismo em Roma, à atmosfera controlada sob o signo da Resistência em Milão, passando, em São Paulo, pelo provincialismo de uma burguesia liberal recente e sua imediata relação com uma aristocracia rural, ambas conservadoras, ao paternalismo de esquerda e a intelectualização da razão popular exponenciada nos anos em que viveu na Bahia - Lina atravessou. Não que estivesse imune às idiossincrasias inerentes ao seu tempo e aos paradoxos de sua própria existência mas não seria isso a matéria de todos nós em essência?

Na exposição de 1963, a acusação do lixo como o ponto da encruzilhada continha uma reivindicação de tomada de decisão diante do bívio que se colocava como uma escolha bastante concreta dos caminhos possíveis para o nosso processo de industrialização. A matéria vertente resultado de uma inteligência contida na simplificação da existência dependia necessariamente das instituições, seja no papel da escola para elaboração de um sistema reprodutível e transmissível, seja no diálogo com as

8 Lina Bo Bardi. "Discurso sobre a significação da palavra artesanato". Em SUZUKI, M. (org.) Tempos de Grossura, op. cit., p.18.

9 Id., "Cinco anos entre os brancos". Em Mirante das Artes, op. cit.

10 Instalação de Cildo Meireles. Pietro Bo. Em Hans Ulrich Obrist. The Insides are on the outside. Instituto Lina Bo e Pietro Maria Bardi, 2012/2013.

11 Carta de Lina Bo Bardi a Oscar Niemeyer, s/d., Arquivo Instituto Lina Bo e Pietro Maria Bardi.

12 Lina Bo Bardi, "Sobre 'Forma na Arquitetura' de Oscar Niemeyer", reproduzido em Fabiana Terensi

Stuchi em "Revista Habitat: um olhar moderno há cerca de 50 anos em São Paulo", p.129. 
políticas públicas do setor que balizassem a completude de sua cadeia produtiva, da produção ao consumo, como um projeto de autonomia nacional, vinda "dos esforços duma geração que queria fazer, duma colônia cultural [...] um País". ${ }^{13}$

Essa é a potência que desafia os modos de produção da Arquitetura colocada em A mão do Povo, em 1969, inaugurando o Museu de Arte de São Paulo, na Avenida Paulista. É a mesma potência que traz o vermelho para as janelas do Unhão - uma escolha dos valores desejados válidos. Mais tarde, esse mesmo vermelho vai sangrar a estrutura do edifício-símbolo de São Paulo. É por isso que existe uma perversão contida no ato de reeditar a $A$ mão do Povo como exposição didática. Assim como o lixo, a potência deslocada da teoria em ato se transfigura em gesto afirmativo do status quo, resíduos instransponíveis de uma sociedade desigual.

Diante de sua imagem estampada nos objetos inúteis expostos nas boutiques dos projetos que idealizou, "da privacidade do casal Bardi" ser critério impeditivo para reprodução acadêmica de seus documentos e do único Velázquez do hemisfério sul estar sob um sanduíche de "um vidro repressor", ${ }^{14}$ - o $A$ de Angústia, inscrito em suas publicações de 1946 não parece distante. Sua percepção nesse sentido seria aguda desde o momento que escolhemos a contramão no bívio. "É pelo pior caminho que a história avança.", Lina citaria Marx em uma de suas últimas entrevistas.

Em 1994, um dos seus interlocutores e colaborador, Marcelo Suzuki, dotado da "seleção e intransigência" reivindicada por Lina, trouxe a grossura necessária para o entendimento de sua obra, sem a qual, o catálogo, lançado um anos antes, ficaria incompleto. Em nota prévia da publicação
Tempos de Grossura: o design no impasse, Suzuki afirma que em 1981, Lina interrompeu os trabalhos de preparação do livro, sob o temor de que suas ideias caíssem no vazio.

Mas o vazio também carrega seu binômio complementar: o projeto. E é pela práxis - teoria e prática ao mesmo tempo - que Lina transforma as oposições binárias em pares complementares. $\mathrm{E}$ nesse exercício de transformação do mundo na formalização de um juízo, suas ideias atravessaram sinalizando uma ética rigorosa que devolveu a pracheta como instrumento político a toda uma geração de arquitetos confrontados com a autoridade do projeto denunciada no programa estético-político do Sérgio Ferro, a partir das relações de produção contidas no canteiro. Frente às implicações contidas no nosso processo de industrialização, o caminho apontado por Lina não apenas passa pelo projeto, mas pela sistematização de um método capaz de reproduzi-lo.

Ciente de que o sertão é um mito de origem e, o Nordeste, uma definição política, Lina soube articular vaqueiro e lampião, romarias e orixás a um só tempo. O tempo da grossura, o popular visto pela ótica de quem o produz. Em toda sua polifonia de sentidos e simplificações generalizantes, aqui sua mirada é o projeto, codificado em ações pedagógicas, num tempo - hoje distante - em que as instituições eram pensadas como um caminho para a democracia.

Conclusão: estamos ainda sob o céu cinzento do pós-guerra. "Tout est permis, Dieu n'existe pas." Mas o que existiu de verdade foi a Guerra, que ainda continua, como continuam as grandes resistências. [Lina Bo Bardi. "O projeto arquitetônico", 1986. RUBINO, GRINOVER: 147-54]. 


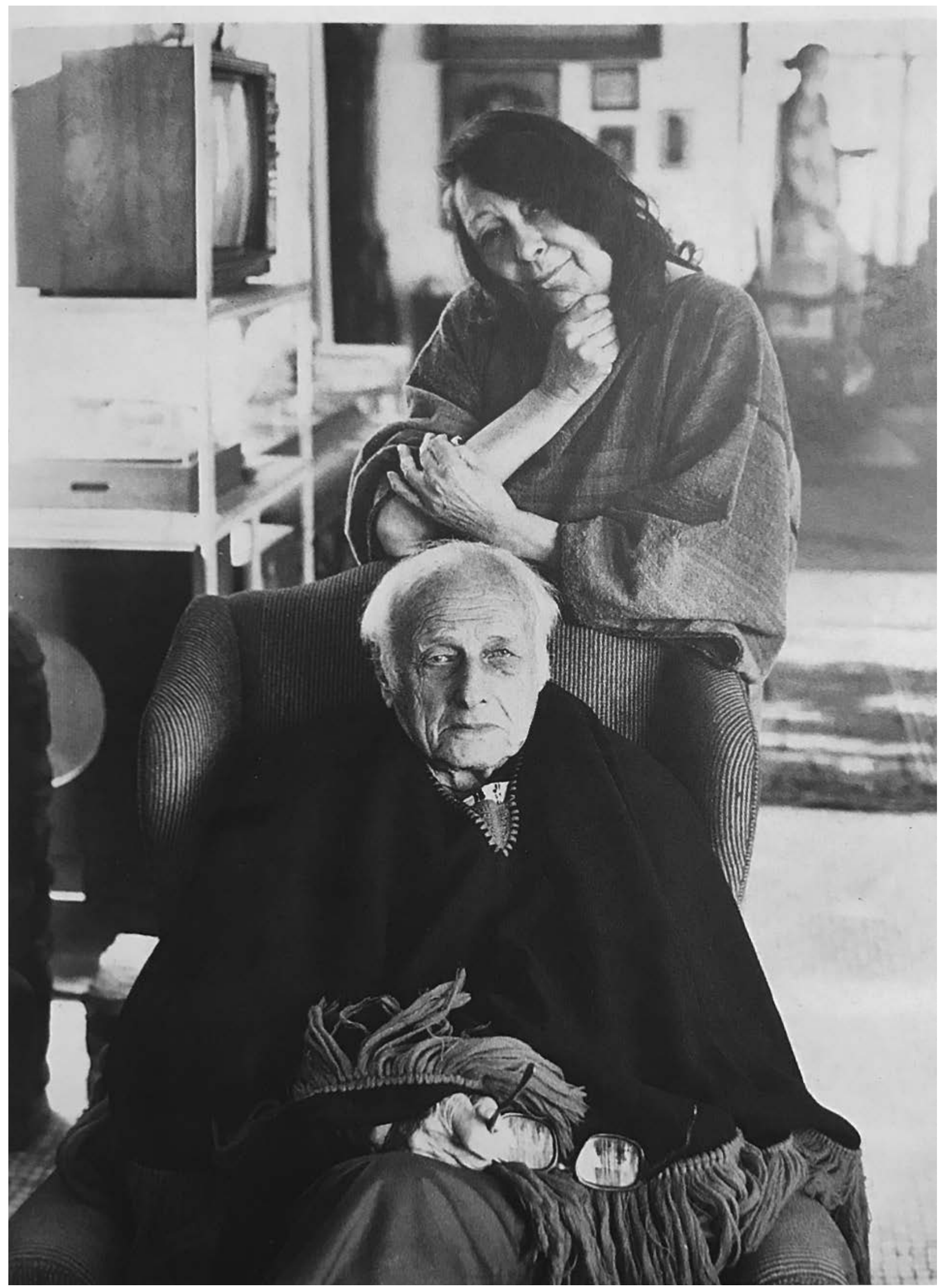

IMG 161.

Lina e Verger

JULIANA VILLELA JUNOUEIRA

[RISERIO, 1995:223]. 



\section{Bibliografia}

ALAmbert, Francisco. As bienais de São Paulo da era do museu era dos curadores. São Paulo: Boitempo, 2006.

AMADO, Jorge. Bahia de Todos os Santos: guia das ruas e dois mistérios da cidade de Salvador. São Paulo: Companhia das Letras. 2012.

AMARAL, Aracy. Arte Construtiva no Brasil. São Paulo: D.B.A., 1998

ANELLI, Renato L. S.Interlocuções com a arquitetura italiana na constituição da arquitetura moderna em São Paulo. Anais.. São Paulo: USP, 2001.

ANDRADE, Oswald. A utopia antropofágica. São Paulo, Global, 1995.

ARGAN, Giulio Carlo. Arte Moderna: do iluminismo aos movimentos contemporâneos. São Paulo: Companhia das Letras, 1992.

. "A História na atividade de projeto". In: Revista Caramelo, n.6, FAUUSP, 1992

. História da Arte como História da Cidade. São Paulo: M. Fontes, 1998.

- Projeto e destino. São Paulo: Ática, 2004.

. Walter Gropius e a Bauhaus. Rio de Janeiro, José Olympio, 2005.

BARDI, Lina Bo. Contribuição propedêutica ao Ensino da Arquitetura. São Paulo: Habitat, 1957.

BARDI, Pietro María. "El Museo", El Mundo de los Museos. Buenos Aires: CODEX, 1967, p. 23. Sodalício com Assis Chateaubriand. São Paulo: Museu de Arte de São Paulo Assis Chateaubriand, 1982.

. História do M.A.S.P. São Paulo: Instituto Quadrante, 1992.

BELLUZZO, Ana Maria de Moraes. Artesanato, Arte e Indústria. Tese apresentada a FAUUSP, 1988. . "Exposição A Mão do Povo Brasileiro". Palestra IEA, 07 de nov. 2017.

BEZERRA DE MENEZES, Eduardo D. O barroco como cosmovisão matricial do êthos cultural brasileiro. Revista Ciências Sociais, vol. 39, n. 1, p. 49-77.

BOLLE, Wille. Grandesertão.br - O romance de formação do Brasil. São Paulo: Duas Cidades; Ed. 34, 2004.

BONSIEPPE, Gui. Diseño industrial. Artefacto y projecto. Madrid, Alberto Corazon, 1975.

BORIS, Fausto. História do Brasil. São Paulo: Edusp, 2000.

BOSI, Alfredo. História concisa da literatura brasileira. 3.ed. São Paulo: Cultrix, 1981.

BRANDI, Cesare. "Il fundamento teorico del restauro", Il Restauro, teoria e pratica 1939-1986, Roma: Editori Riuniti, 1994.

BUARQUE DE HOLANDA, Sérgio. Raízes do Brasil. 5ed. Rio de Janeiro: 1969

CÂNDIDO, Antônio. A Educação pela noite e outros ensaios. 3. ed. São Paulo: Ática, 2000.

CAVALCANTI, Lauro. Moderno e brasileiro, a história de uma nova linguagem na arquitetura 1930-1960.

CUNHA, Euclides da [1902]. Os Sertões [Campanha de Canudos]. 3ed corrigida. São Paulo / Rio de Janeiro: LAEMMERT \& C. Livreiros Editores, 1905.

FAUSTO, Boris. História do Brasil. São Paulo: Edusp, 2000. 


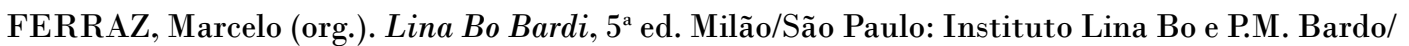
Romano Guerra, 2018.

. João Vilanova Artigas. São Paulo: Instituto Lina Bo e PM Bardi, 1997.

FERRAZ, I. G. e MICHILES, A. Lina Bo Bardi. Documentário em VHS. São Paulo: Instituto Lina Bo e P. M. Bardi, 1993.

FERRO, Sérgio. Arquitetura e trabalho livre. São Paulo: Cosac Naify, 2006.

FURTADO, Celso. Uma política de desenvolvimento econômico para o Nordeste. SUDENE. Rio de Janeiro: Departamento de Imprensa Nacional, 1959.

A Pré-Revolução Brasileira. Rio de Janeiro: Fundo de Cultura, 1962.

- Análise do "Modelo" Brasileiro. 6a ed. Rio de Janeiro: Editora Civilização Brasileira, 1978.

.Quem somos? Sete teses sobre a cultura brasileira". Rio de Janeiro: Revista do Brasil, ano

$\mathrm{I}, \mathrm{n.2} / 84$.

. A Fantasia Desfeita. São Paulo, Paz e Terra, 1997.

FURTADO, Rosa Freire d'Aguiar (org.) Ensaios sobre cultura e o Ministério da Cultura. Arquivos Celso Furtado. Rio de Janeiro: Editora Contraponto/Centro Internacional Celso Furtado, 2012. GERBER, Raquel. Glauber Rocha. São Paulo: Paz e Terra, 1977.

GRAMSCI, Antonio. Quaderni del Carcere: Edizione crittica dell'Istituto Gramsci a cura di Valentino Gerratana. Torino: Einaudi, 2007. 4 vol.

GRINOVER,M.; RUBINO, S.; (orgs.). Lina por escrito. Textos escolhidos de Lina Bo Bardi. São Paulo: Cosac Naify, 2009.

. Uma idéia de arquitetura : escritos de Lina Bo Bardi. Dissertação de Mestrado apresentada a FAUUSP, 2010.

LABORATÓRIO DE PROJETO E CONSTRUÇÃOO prática da arquitetura na obra de

Renzo Piano e João Filgueiras Lima. Tese apresentada a FAUUSP, 2015.

GROPIUS, Walter. Scope of Total Architecture. New York, 1943.

GULLAR, Ferreira. Cultura posta em questão. Rio de Janeiro : Editôra Civilização Brasileira, 1965. IANNI, O. Origens agrárias do Estado brasileiro. São Paulo, Brasiliense, 1984.

JORGE, Luis Antônio. Espaço Seco: Imaginário e poéticas da arquitetura na América. Tese doutorado. FAUUSP, 1995.

. "El dibujo en Lina Bo Bardi: fábula, política y poética”. In: LLORENS, M.; JUNCO,MF; GUTIÉRREZ (orgs.). Lina Bo Bardi. Tupí or not tupí. Fundación Jauan March, 2018.

KATINSKY, Júlio Roberto. Desenho industrial e artesanato [Apresentação]. Design brasileiro: quem fez, quem faz[S.l: s.n.], 2005.

KUBITSCHEK, Juscelino. Por que construí Brasília. Rio de Janeiro: Bloch Editores S.A., 1975.

LE CORBUSIER. Precisões sobre um estado presente da arquitetura e do urbanismo. São Paulo, Cosac \& Naify, 2004.

LEON. Ethel. IAC - Instituto de Arte Contemporânea escola de desenho industrial do MASP (1951-1953) - primeiros estudos. Dissertação de Mestrado apresentada a FAUUSP, 2006.

LÉVI-STRAUSS, Claude. Tristes Trópicos. São Paulo: Companhia da Letras, 1996.

LOURENÇO, Maria Cecília. Museus acolhem moderno. São Paulo: E.D.U.S.P., 1999.

MALDONADO, Tomas. "As artes industriais". 6 a sessão do Congresso Internacional de Críticos de Arte, 1959. Em Anais do Congresso Internacional de Críticos de Arte, pp.102-3.

.El Diseño Industrial Reconsiderado. Barcelona: GG, 1993.

MOHOLY-NAGY, L. La Nueva Visión y Reseña de un artista. Buenos Aires: Ediciones Infinito, 1997. NOBRE, Ana Luiza. Fios Cortantes. Projeto, produto, arquitetura e design no Rio de Janeiro. Tese de Doutorado apresentada a PUC-Rio, 2009.

OLIVEIRA, Olivia. Lina Bo Bardi, $2 G$ n. 23- 24.

PAGANO, Giuseppe. Architettura Rurale Italiana. Milão: Ulrico Hoepli, 1936.

PAZ, Octávio. Signos em rotação. Rio de Janeiro: Perspectiva, 1990.

PEREIRA, Carlos da Costa. Artesanato e Arte Popular. Bahía: Instituto de Economia e Finanças da Bahia, Livraria Progresso, 1957.

PEREIRA, Juliano Aparecido; Sobral Anelli, Renato Luiz. "Uma Escola de Design Industrial referenciada no lastro do pré-artesanato: Lina Bo Bardi e o Museu do Solar do Unhão na Bahia". Revista Design em Foco, vol. II, núm. 2, julho-dezembro, 2005, p.24.

. Lina Bo Bardi, Bahia 1958-1964. Uberlândia: Editora EDUFU, 2008. 
. Desenho Industrial e Arquitetura no Ensino da FAU USP (1948-1968). Tese apresentada ao IAU-USP, 2009.

PIGNATARI, D. In: Abstracionismo Geométrico e Informal, a vanguarda brasileira nos anos cinquenta, Funarte, Rio de Janeiro, 1987.

RIEGL, Alois. Arte Tardoromana. Turim: Giulio Einaudi, 1959.

RISÉRIO, Antonio. Avant-garde na Bahia. São Paulo: Instituto Lina Bo e P. M. Bardi, 1995.

ROCHA, Glauber. "Uma estética da fome”, Revista Civilização Brasileira, n. 3, jul. de 1965.

RUBINO, Silvana Barbosa. "Gramsci no Museu, ou a arte popular no Solar do Unhão, Salvador 1963-64". Conferencia apresentada na 26a Reunião Brasileira de Antropologia, em Porto Seguro, Bahia, 2008.

SANTOS, Cecília Rodrigues dos [et ali.]. Le Corbusier e o Brasil. São Paulo: Tesseia: Projeto Editora, 1987.

SCALDAFERRI, Sante. Os Primórdios da Arte Moderna na Bahia. Salvador: Fundação Cultural do Estado da Bahia, Fundação Casa de Jorge Amado, 1998.

SCHWARZ, Roberto. “Ao Vencedor As Batatas”. São Paulo: Duas Cidades, 1992.

SOUZA, Rodrigo Mendes. O olho e a mão: Walter Gropius. Dissertação de mestrado apresentada a FAUUSP, 2014.

.O desenho da Utopia - Paul Klee. Tese de doutorado, apresentada a FAUUSP, 2019.

STUCHI, Fabiana. "Revista Habitat: um olhar moderno há cerca de 50 anos em São Paulo". São Paulo: F.A.U.U.S.P., 2006.

SUZUKI, Marcelo. (org.). Tempos de Grossura: o design no impasse. São Paulo: Instituto Lina Bo e P. M. Bardi, 1994.

. Lina e Lucio. Tese de Doutorado. IAU-USP, 2010.

TELLES, Sophia S. O contorno do Infinito. Sãp Paulo, 1983.

VAN EYCK, Aldo. "Um dom superlativo", em Museu de Arte de São Paulo. Lisboa: Blau, 1997.

WARCHAVCHIK, Gregori. Arquitetura do século XX e outros escritos. São Paulo: Cosac Naify, 2006, p.171.

WISNIK, Guilherme (org.). O Risco, Lucio Costa e a utopia moderna.

. Dentro do nevoeiro: diálogos cruzados entre arte e arquitetura contemporânea. Tese de Doutorado apresentada a FAUUSP, 2012.

XAVIER, A. Lúcio Costa: sôbre arquitetura. Porto Alegre: Uniritter, 2007.

. Depoimento de uma geração. São Paulo: Cosac Naify, 2003.

\section{Periódicos:}

A Cultura della Vita $n .8$ (1 de jun. de 1946).

A Cultura della Vita $n .7$ (25 de mai. de 1946).

A Cultura della Vita, n.9 (8 de jun.de 1946).

A Tarde, 4 de nov., 1963.

A Tarde Cultural, 23 de out. de 1993: 3

Ângulos n.6 (dez. de 1960): 121-124.

Crônicas de arte, de história, de costumes, de cultura da vida 1, Diário de Notícias (7 de set. de 1958). Crônicas de arte, de história, de costumes, de cultura da vida 2, Diário de Notícias (14 de set. de 1958). Crônicas de arte, de história, de costumes, de cultura da vida 3, Diário de Notícias (21 de set. de 1958). Crônicas de arte, de história, de costumes, de cultura da vida 4, Diário de Notícias (28 de set. de 1958). Crônicas de arte, de história, de costumes, de cultura da vida 5, Diário de Notícias (5 de out. de 1958). Crônicas de arte, de história, de costumes, de cultura da vida 6, Diário de Notícias (12 de out. de 1958). Crônicas de arte, de história, de costumes, de cultura da vida 7, Diário de Notícias (19 de out. de 1958). Crônicas de arte, de história, de costumes, de cultura da vida 8, Diário de Notícias (26 de out. de 1958). Diário de São Paulo, 08 de agosto de 1948.

Diário de São Paulo, 8 de março de 1950.

Domus n.191, nov.1943:464.

Domus n. 279 (fev. de 1953): 19-26, 
Domus n.284 (jul. de 1953): 22-26;

Habitat n.1 (out.-dez. de 1950)

Habitat n.2 (jan.-mar. de 1951)

Habitat n.3 (abr.-jun. de 1951)

Habitat 4 (jul.-set. de 1951)

Habitat, n.6 (jan.-mar. de 1952)

Habitat 7 (abr.-jun. de 1952)

Habitat 8 (jul.-set. de 1952)

Habitat n.9 (out.- dez. de 1952)

Habitat n.10 (jan.-mar. de 1953)

Habitat, n.14 (jan.-fev. de 1954)

Jornal da Bahia, 21 de set. de 1960.

Jornal da Bahia, 17 de mar. de 1961.

Jornal do Brasil - Suplemento Literário, 17 dez. de 1970.

L'Architettura - Cronache e Storia, n.109, Milão, Nov. 1964, pp. 436-37

Malasartes, Rio de Janeiro, n. 2, p. 4-6, jan/fev/mar 1976.

Módulo, n. 9 (fev.de 1958): 3-6.

Mirante das Artes, n.1, jan-fev. 1967.

Museum vol. I, n. 3-4.

The Architectural Review (out.1951): 261-262

The Architectural Review. (set. de 1952): 160-163

The Architect and Building News (abr. de 1953): 488-494,

The Architectural Review (jul. de 1953): 12-13

\section{Materiais de arquivo:}

Arquivo Instituto Lina Bo e P.M. Bardi [ILBPMB]:

Lina Bo Bardi. Carta a Oscar Niemeyer, s/d.

. Pedido ao diretor da Bienal Ciccillo Matarazzo Sobrinha em carta, datada 13/03/1959.

.Carta a Eros Martim Gonçalves e registrada em São Paulo, 18 de jul. de 1959.

.; GONÇALVES, Martim. Bahia: exposição no Parque Ibirapuera. São Paulo, Folder da

Exposição, 1959.

.Rascunho carta enviada a Celso Furtado em 05/03/64.

. Carta a Reidy, jul. de 1982.

. "Conceituação do Programa".

- "Pro-memória para uma ação na Bahia".

. "Solar do Unhão", 1963. Arquivo ILBPMB.

. Catálogo de exposição "Caipiras, capiaus: pau-a-pique", realizada no S.E.S.C. Pompéia, em 1984.

. Carta de Celso Furtado. 5 de abril de 1964. Arquivo ILBPMB. $2 \mathrm{fl}$

. Catálogo Civilização Nordeste, 1963. Arquivo ILBPMB.

• "Contribuição da cultura popular à arquitetura", Arquivo ILBPMB

- Catálogo Brennand Cerâmica. Museu de Arte Moderna da Bahia, 1961.

. Conferência "Arquitetura como Habitação". Programa de curso, 1961.

. Depoimento para o livro Arte na Bahia. Teatro da Universidade (Salvador da Bahía:

Corrupio e Empresa Gráfica da Bahia, 1991.)

MENEZES, Aureliana. Entrevista com a arquiteta Lina Bo Bardi. FAU-USP, 20 de agosto de 1976.

\section{Arquivo Museu de Arte Moderna da Bahia [MAMB]:}

Lina Bo Bardi. Manuscrito editado da primeira aula no curso de arquitetura da Faculdade de Belas-artes da Universidade Federal da Bahia em 1958.

. Texto datilografado sem título, escrito em Salvado, datado em 17 de outubro de 1959.

. Entrevista para III Semana Nacional de Estudantes de Filosofia, na Faculdade de Filosofia, Ciências e Letras da Universidade do Paraná, 1960 [data aproximada]. 
. "Calígula" e a crítica teatral".

. Lista de Exposições realizadas no MAMB.

. Resumo das Atividades do Museu de Arte Moderna da Bahia. Arquivo MAMB, s/d., escrito por volta de 1960 .

. Rascunho Texto de assinatura de convênio, s/d, escrito por volta de 1960.

. Nota sobre MAMB, sem data.

. Exposições Museu Arte Popular 1963.

. Biênio propedêutico.

Carta manuscrita ao governador da Bahia, Lomanto Júnior, escrita em Salvador, 01/05/1963.

. Rascunho de carta enviada a Milton Santos em 06/06/1963. Arquivo MAMB. Rascunho de carta para o governador do Estado da Bahia, Antônio Lomanto Júnior. 1 de maio de 1963. Arquivo MAMB.

. Projeto da Escola de Artesanato. Dados informativos sobre o conjunto arquitetônico do Solar do Unhão e as atuais atividades do MAMB e MAP Unhão.

."Il Museo d'Arte Moderna". Texto datilografado, em data. Arquivo M.A.M.B.

. Nota manuscrita sobre os orçamentos do "Il Museo d'Arte Moderna da Bahia", sem data. Arquivo M.A.M.B.

. Carta a Ciccillo Matarazzo (datilografado). Arquivo MAMB, Salvador, 19 out. 1960.

. Relatório das atividades do Museu de Arte Moderna da Bahia no ano de 1960. (datilografado). Arquivo MAMB, Salvador, 1960.

. As exposições de pintura brasileira... (datilografado). Arquivo MAMB, Salvador, 1960.

Técnica e arte (datilografado). Arquivo MAMB, Salvador, 1960 (data provável)

.Nós e o passado. Exposições Didáticas no MAMB. Salvador, p. s/n, primeira versão, 1960[?]

Formas Naturais. Exposições Didáticas no MAMB. Salvador, p. s/n, primeira versão, 1960[?]

.Ver a pintura (didática). Exposições Didáticas no MAMB. Salvador, p. s/n, 15 mar 1960

Exposição nós e o passado. Exposições Didáticas no MAMB. Salvador, p. s/n, 1960[?] Formas

Naturais. Exposições Didáticas no MAMB. Salvador, p. s/n, segunda versão, 1960[?]

.Museu de Arte Moderna da Bahia. Salvador, [1959?]. Depoimento datiloescrito.

. Esquema para a elaboração de um projeto para a instalação de um museu de arte popular e

de uma escola de desenho industrial e de artesanato (datilografado) . Arquivo MAMB, Salvador, s/d.

. Estudos para o Museu de Arte Popular da Bahia (datilografado). Arquivo MAMB, Salvador,

s/ d. Neo-concretismo al Belvedere da Sé (mimeo). Arquivo MAMB, Salvador, s/d.

. Documento em resposta a um artigo de Carybe $\square$ para a revista Manchete(mimeo), Arquivo

MAMB s/d. Eis mais uma exposição. (datilografado). Arquivo MAMB, Salvador, 1961.

. A cadeira na história. Museu de Arte Moderna da Bahia, Salvador, 1962. 
